FERNANDA DE MAGALHÃES DIAS FRINHANI

\title{
As Representações Sociais dos Profissionais do Direito sobre Tráfico de Pessoas
}

Tese de Doutorado

Orientação: Profa. Dra. Lídia Reis de Almeida Prado

UNIVERSIDADE DE SÃO PAULO

FACULDADE DE DIREITO

SÃO PAULO 


\section{As Representações Sociais dos profissionais do Direito sobre Tráfico de Pessoas}

Tese de Doutorado apresentado ao Programa de Pós-Graduação em Direito da Faculdade de Direito da Universidade de São Paulo para obtenção do título de Doutora em Direito.

Área de Concentração: Direitos Humanos

Orientador: Profa. Dra. Lídia Reis de Almeida Prado 
Autorizo a reprodução e divulgação total ou parcial deste trabalho, por qualquer meio convencional ou eletrônico, para fins de estudo e pesquisa, desde que citada a fonte.

Serviço de Biblioteca e Documentação Faculdade de Direito da Universidade de São Paulo

\section{Frinhani, Fernanda de Magalhães Dias}

F949r As representações sociais dos profissionais do direito sobre o tráfico de pessoas / Fernanda de Magalhães Dias Frinhani. - - São Paulo: USP / Faculdade de Direito, 2014.

$207 \mathrm{f}$.

Orientadora: Prof ${ }^{\mathrm{a}}$. Drạ . Lídia Reis de Almeida Prado

Tese (Doutorado), Universidade de São Paulo, Faculdade de Direito, Programa de Pós-Graduação em Direito, 2014.

1. Tráfico humano. 2. Direitos humanos. 3.Políticas públicas. 4. Direitos Humanos - Tese doutorado. I. Prado Lídia Reis de Almeida. II. Universidade de São Paulo, Faculdade de Direito, Programa de Pós-Graduação em Direito. III. Título. 
FRINHANI, F. M. D. As Representações Sociais dos profissionais do Direito sobre

Tráfico de Pessoas. Tese apresentada à Faculdade de Direito da Universidade de São Paulo para obtenção do título de Doutora em Direitos Humanos.

Aprovado em: São Paulo, de de 2014.

Banca Examinadora

Profa. Dra. Lídia Reis de Almeida Prado Instituição: USP Julgamento: Assinatura:

Prof.. Dr. Instituição:

Julgamento:

Assinatura:

Prof. Dr. Instituição: Julgamento:

Assinatura:

Prof. Dr.

Instituição:

Julgamento:

Assinatura:

Prof. Dr. Instituição:

Julgamento:

Assinatura: 
Dedico este trabalho a meus pais Aloísio Frinhani e Alfa Maria de Magalhães Dias Frinhani, que perdi, coincidentemente, ao longo deste processo. Dedico a eles que acreditaram que a melhor herança que se pode deixar a um filho é o estudo. Que acreditaram que os filhos são feitos para o mundo. Que acreditaram em mim mais que eu mesma. Que me fizeram ser forte e acreditar que conseguiria concluir cada passo apesar da dor e da saudade. Que me ensinaram, diariamente, a honrar pai e mãe. Espero ter conseguido cumprir esta missão com esta tese.

A pesada janela de madeira range ao ser aberta. Olho para o quintal cheio de plantas. Em destaque a jabuticabeira zelosamente cuidada. Espero o barulho da máquina cessar e grito:

_ Bença, Pai!

_. Deus te abençoe minha filhinha!

Abro a porta do quarto e a escoro com o pesado carrinho de madeira feito por ele. Olho as paredes e vejo meus pais por todos os cantos: uma parede de pedra, uma coruja, um mosaico, um cavalo... Do aparelho de som sai uma música, sempre de boa qualidade.

_ Bença, Mãe!

_ Deus te abençoe meu amor!

Encontro minha mãe bordando. Mesa posta.

_ Quer chá, filha?

Os cachorros latem...

Agora tudo está vazio. Meu peito está vazio.

_ Bença, Pai!

_ Bença, Mãe!

Já não tenho mais resposta...

"E eu não sabia que a minha história era mais bonita que a de Robson Crusoé."

(Homenagem feita a meus pais por ocasião da morte de minha Mãe, em 24 de agosto de 2011. A última frase, de autoria de Carlos Drummond de Andrade, poema Infância.) 


\section{RESUMO}

FRINHANI, Fernanda de Magalhães Dias. As Representações Sociais dos profissionais do Direito sobre Tráfico de Pessoas. 2014. $207 \mathrm{f}$. Tese (Doutorado em Direitos Humanos) - Faculdade de Direito, Universidade de São Paulo.

Este estudo tem como objetivo uma análise das representações sociais de tráfico de pessoas por profissionais do Direito envolvidos com a implantação da Política de Prevenção e Enfrentamento ao Tráfico de Pessoas no Estado de São Paulo. O tráfico de pessoas é um tema que entrou na pauta das políticas governamentais com a adoção pelo Brasil, no ano de 2004, do Protocolo Adicional à Convenção das Nações Unidas contra o Crime Organizado Transnacional relativo à Prevenção, Repressão e Punição do Tráfico de Pessoas, em Especial Mulheres e Crianças - Protocolo de Palermo. O estudo de uma política com foco em Direitos Humanos nos permite uma discussão acerca da atuação dos profissionais do Direito em uma dimensão humanista, possibilitando refletir sobre suas práticas e seus olhares para os sujeitos envolvidos. A teoria das representações sociais é um referencial teórico da Psicologia Social que, entre outras coisas, permite conhecer as formas como determinado grupo transforma um novo saber em algo familiar dentro de um determinado contexto histórico e social. Sua escolha se justifica por entendermos que desvendar o olhar dos profissionais do Direito sobre a Política de Enfrentamento ao Tráfico de Pessoas é passo importante para definir os limites e as potências da atuação dos profissionais na política em questão e, com isso, propor transformações nas respectivas práticas. Para alcançar o objetivo, além de pesquisa bibliográfica sobre direitos humanos e tráfico de pessoas, foram entrevistados oito profissionais do Direito envolvidos com a política de enfrentamento ao tráfico de pessoas no Estado de São Paulo, por meio de entrevistas semiestruturadas, com a definição de alguns pontos importantes a serem abordados. As entrevistas foram gravadas e a transcrição feita pela pesquisadora, sendo de natureza qualitativa a análise dos dados, que foram submetidos à análise de conteúdo. Foram estabelecidas categorias encontradas nas respostas dos sujeitos, condizentes com os objetivos do trabalho, sendo encontradas as seguintes: $\mathrm{O}$ olhar dos profissionais do Direito sobre si mesmos; Violência como causa e como consequências do tráfico de pessoas; Maiores dificuldades em trabalhar os temas tráfico de pessoas e Direitos Humanos; Os sujeitos/objetos do tráfico de pessoas; Os eixos temáticos e a intersetorialidade da política. Como conclusão, entendemos que a política estudada vem evoluindo desde sua implantação no Brasil e que os profissionais do Direito têm sido protagonistas importantes neste processo, seja como agentes da política, seja como profissionais que levam ao Judiciário as demandas que envolvem o tráfico de pessoas. Em qualquer das dimensões, entendemos ser fundamental que haja uma reflexão sobre a formação desses profissionais nas faculdades de Direito, de modo a possibilitar uma prática comprometida com os ideais dos direitos humanos, com a dignidade da pessoa, com a inclusão social e com a dimensão social do Direito.

Palavras-chave: Tráfico de Pessoas. Direitos Humanos. Políticas Públicas. Teoria das Representações Sociais. 


\begin{abstract}
FRINHANI, Fernanda de Magalhães Dias. Social Representations of legal practitioners about Trafficking in Persons. 2014. $207 \mathrm{f}$. Dissertation (Doctoral degree in Human Rights) - Faculdade de Direito, Universidade de São Paulo.

The present study aims to analyze the social representations of trafficking in persons by legal practitioners involved on the implementation of the Policy to Prevent and Confront Trafficking in Persons in the State of São Paulo. Trafficking in persons is a subject that started to be discussed on governmental policies after Brazil adopted the Additional Protocol to the United Nation Convention against transnational organized crime related to Prevent, Suppress and Punish Trafficking in Persons, mainly women and children - Palermo Protocol, in 2004. A study of a policy focused on human rights allow us to discuss about the performance of legal practitioners in a humanist dimension, enabling reflections about their practices and their point of view about the involved subjects. The social representations theory is a theoretical reference from Social Psychology that, among other things, allows us to know the way how a specific group transforms a new knowledge in to something familiar inside one specific historical and social context. This choice is justified through the understanding that the discover of legal practitioners' point of view about the Policy of Confronting Trafficking in Persons is an important step for defining limits and potential involvement from practitioners on this specific policy, and additionally, propose transformations on respective practices. To reach the objective, in addition to the bibliographical research about human rights and trafficking in persons, eight legal practitioners involved with the policy of confronting trafficking in persons on the state of São Paulo, were interviewed. Those interviews were semi structured and some important points to be approached were previously defined. They were recorded and the transcription was made by the researcher. The data analysis were qualitative by nature, data were submitted to content analysis, with establishment of analysis' categories founded on subjects' responses and corresponding with the aims of the work. The following categories were founded: The point of view of legal practitioners about their selves; Violence as causes and consequences of trafficking in persons; Greatest difficulties on working with topics trafficking in persons and human rights; The subjects/objects of trafficking in persons; The thematic axes and the policy's intersectoriality. As conclusion, we understand that the studied policy is progressing since its implementation in Brazil and the legal practitioners have been important actors on this process, as policy's agents or practitioners that take to judiciary demands that involve trafficking in persons. In any of the dimensions, we understand the fundamental importance of reflecting about the development of those professionals on Faculty of Law allowing a compromised practice with the Human Rights' ideal, with human dignity, with social inclusion and with social dimension from the Right.
\end{abstract}

Keywords: Trafficking in Persons. Human Rights. Public policies. Theory of Social Representations. 


\section{LISTA DE SIGLAS}

ASBRAD Associação Brasileira de Defesa da Mulher, da Infância e da Juventude

CAMI Centro de Apoio ao Migrante

CAPES Coordenação de Aperfeiçoamento de Pessoas de Nível Superior

CEITEPT Comitê Estadual Interinstitucional de Prevenção e Enfrentamento ao Tráfico de Pessoas

COETRAE Comitê Estadual de Enfrentamento ao Trabalho Escravo

CONATRAP Comitê Nacional de Enfrentamento ao Tráfico de Pessoas

CPI

CRIPETP Comitês Regionais Institucionais de Prevenção e Enfrentamento ao Tráfico de Pessoas

DHPP Delegacia de Homicídio e Proteção à Pessoa

GTI

Grupo de Trabalho Interministerial

IDG Índice de Desigualdade de Gênero

IPEA Instituto de Pesquisas Econômicas Aplicadas

LGBT Lésbicas, Gays, Bissexuais, Travestis, Transexuais

LO Linha Operativa

MJ Ministério da Justiça

MP Ministério Público

NETP Núcleo de Enfrentamento ao Tráfico de Pessoas

OIT Organização Internacional do Trabalho

ONG Organizações Não Governamentais

ONU Organização das Nações Unidas

P Participantes (P1, P2, P3, P4, P5, P6, P7, P8)

PEPETP Programa Estadual de Prevenção e Enfrentamento ao Tráfico de Pessoas

PESTRAF Pesquisa Nacional sobre Tráfico de Mulheres, Crianças e

Adolescentes

PLS Projeto de Lei do Senado

PM Polícia Militar

PNETP Plano Nacional de Enfrentamento ao Tráfico de Pessoas

PPAs Planos Plurianuais

PRONASCI Programa Nacional de Segurança e Cidadania

SDH Secretaria de Direitos Humanos

SENASP Secretaria Nacional de Segurança Pública

SINAN Sistema de Informação de Agravos de Notificações do Ministério da Justiça

SJDC Secretaria de Justiça e Defesa da Cidadania

SNJ Secretaria Nacional de Justiça

SPM Serviço Pastoral do Migrante

STF Supremo Tribunal Federal

SUS Sistema Único de Saúde

UNIFEM Fundo das Nações Unidas para as Mulheres

UNODC Escritório das Nações Unidas sobre Droga e Crime 


\section{SUMÁRIO}

1 Apresentação ........................................................................... 10

2 A emergência da proteção dos Direitos Humanos - Colocando os 16

Direitos Humanos em pauta

2.1 Direitos Humanos, Políticas Públicas e Judiciário: onde os profissionais do Direito se encontram.

2.2 As discussões sobre o universalismo e o relativismo cultural: há lugar para um consenso?.

3 O tráfico de pessoas como uma preocupação.

3.1 - Tráfico de pessoas: conceito e histórico

36

3.2 - O tráfico de pessoas e o poder econômico

36

3.3 - Quem são as vítimas do tráfico de pessoas

41

3.4 - Polêmicas sobre o consentimento e sobre a distinção entre 44 tráfico de pessoas e contrabando de migrantes

3.5 - Vulnerabilidades de origem e de destino

3.6 - A Política Nacional de Enfrentamento ao Tráfico de Pessoas

4 Problema de pesquisa, delimitação do tema e objetivos

5 Método 64

5.1 - Procedimento e instrumento de coleta de dados . 73

5.2 - Procedimento de análise de dados 73

6 Apresentação, discussão e análise dos dados 84

6.1 - Categoria 1 - Autorretrato: O olhar dos profissionais do 84 Direito sobre si mesmos

6.2 - Categoria 2 - Vulnerabilidades: Violências como causa e como consequências do tráfico de pessoas

6.3 - Categoria 3 - Desafios: Maiores dificuldades em trabalhar o tema tráfico de pessoas e Direitos Humanos.

6.4 - Categoria 4 - Vítimas: os sujeitos/objetos do tráfico de pessoas

6.5 - Categoria 5 - Articulações - Os eixos temáticos e a 162 intersetorialidade da política

7 Considerações Finais

8 Referências

9 Anexo 


\section{1 - APRESENTAÇÃO 1}

\section{O reconhecimento da dignidade inerente a todos os membros da família humana e de seus direitos iguais e inalienáveis é o fundamento da liberdade, da justiça e da paz no mundo ${ }^{2}$}

O presente trabalho busca uma análise das Representações Sociais de Tráfico de Pessoas por Profissionais do Direito envolvidos com a implantação da Política de Prevenção e Enfrentamento ao Tráfico de Pessoas no Estado de São Paulo.

A Teoria das Representações Sociais é um referencial teórico da Psicologia Social que busca dar sentido ao conjunto de conceitos, afirmações e explicações expostas por indivíduos que tenham alguma afinidade em suas práticas ou vivências. Busca uma compreensão do senso comum estando inserida num universo consensual que comporta opiniões advindas das vivências cotidianas, buscando compreender também as práticas do sujeito em relação a situações que enfrenta. Deste modo, permite conhecer as formas como determinado grupo transforma um novo saber em algo familiar dentro de um determinado contexto histórico e social.

Entendendo que a participação do sujeito no processo de construção dos saberes é importante e que esta participação interfere necessariamente em suas práticas, acreditamos que investigar as Representações Sociais (teoria) dos Profissionais do Direito (sujeitos) sobre Tráfico de Pessoas (objeto), auxilia na compreensão de como estes sujeitos constroem suas ações cotidianas como profissionais e como membros da Política de Prevenção e Enfrentamento ao Tráfico de Pessoas do Estado de São Paulo.

\footnotetext{
${ }^{1}$ Trabalho desenvolvido de acordo com as normas da ABNT, conforme apresentado em Funaro (2009).

2 Inspirado no primeiro considerando do Preâmbulo da Declaração Universal dos Direitos Humanos.
} 
A escolha do tema se justifica por sua relevância social além da jurídica. Social em razão da emergência do tema tráfico de pessoas, incluído no debate nacional a partir da ratificação do Protocolo de Palermo ${ }^{3}$ em 2004. Em 2006, o Brasil editou a Política Nacional de Prevenção e Enfrentamento ao Tráfico de Pessoas e em 2008 o I Plano Nacional sobre o mesmo tema. Em 2013, com mais de um ano de atraso, foi editado o II Plano Nacional, acolhido como a "expressão mais concreta do compromisso político, ético e técnico do Estado brasileiro em prevenir e reprimir o crime do tráfico de pessoas e garantir a necessária assistência e proteção às vítimas, bem como a promoção de seus direitos" (BRASIL, 2013, p. 08).

O processo de elaboração deste II Plano revela o caráter interdisciplinar e participativo da política em questão. Interdisciplinar não só por reunir em um Grupo de Trabalho Interministerial (GTI) 19 Ministérios e Secretarias de Governo, além da Procuradoria-Geral da República e do Conselho Nacional dos Procuradores-Gerais do Ministério Púbico dos Estados e da União, mas também pelas áreas do conhecimento que abrange. Participativo por ter sido construído a partir de 12 reuniões de trabalho períodicas e uma oficina de diagnóstico sobre os avanços do I Plano com o GTI; 03 (três) colóquios com especialistas, líderes sociais, agências internacionais, Estados e Municípios, e equipes técnicas do sistema de justiça e direitos; análises dos compromissos internacionais do governo brasileiro e das pesquisas sobre o tráfico de pessoas; reuniões bilaterais sobre os Planos Plurianuais (PPAs) de Ministérios e Secretarias; diálogos com a Comissão Parlamentar de Inquérito (CPI) do Senado sobre o tráfico de seres humanos; consulta virtual on-line no site do Ministério da Justiça, com participação de 135 pessoas; 57 plenárias livres com participação de 1500 pessoas, sendo 20 plenárias realizadas em países estrangeiros, além da realização do II Encontro Nacional da Rede de Enfrentamento ao Tráfico de Pessoas em Recife.

\footnotetext{
${ }^{3}$ Protocolo Adicional à Convenção das Nações Unidas contra o Crime Organizado Transnacional relativo à Prevenção, Repressão e Punição do Tráfico de Pessoas. Importante ressaltar que a Convenção possui três protocolos adicionais relativos: ao tráfico de pessoas, ao contrabando de migrantes e ao tráfico de armas, mas nesse trabalho o uso da expressão Protocolo de Palermo restringe-se ao Protocolo Adicional relativo ao Tráfico de Pessoas.
} 
O Estado de São Paulo, pioneiro em ações contra esse tipo de tráfico, ingressou na política nacional em 2009, por meio do Decreto 54.101/09, que instituiu o Programa Estadual de Prevenção e Enfrentamento ao Tráfico de Pessoas - PEPETP, tendo a Secretaria da Justiça e da Defesa da Cidadania como órgão gestor. O Programa é operacionalizado pelo Núcleo de Prevenção e Enfrentamento ao Tráfico de Pessoas que conta com uma equipe multidisciplinar e é apoiado, em caráter consultivo, pelo Comitê Estadual Interinstitucional de Prevenção e Enfrentamento ao Tráfico de Pessoas ${ }^{4}$. Desde então, vem transformando a política de modo a adequar a mesma às expectativas nacionais e às peculiaridades locais. Atualmente, além de consolidar a implantação dos Comitês Regionais Institucionais de Prevenção e Enfrentamento ao Tráfico de Pessoas em várias cidades do Estado ${ }^{5}$, a política ganhou força com a criação do Comitê Estadual de Enfrentamento ao Trabalho Escravo - COETRAE ${ }^{6}$, que tem a finalidade de propor mecanismos para a prevenção e o enfrentamento do trabalho escravo no Estado de São Paulo, articulado com o Programa Nacional do Trabalho Decente, com o Plano Nacional de Erradicação do Trabalho Escravo e com o Plano Nacional de Enfrentamento ao Tráfico de Pessoas.

Esses comitês além de serem um importante passo na efetivação da Política Nacional de Enfretamento ao Tráfico de Seres Humanos revelam o caráter interdisciplinar dessa política. A composição do Comitê Estadual Interinstitucional de Prevenção e Enfrentamento ao Tráfico de Pessoas CEIPETP ${ }^{7}$, assim como do Comitê Estadual de Enfrentamento ao Trabalho Escravo, revelam também a participação dos profissionais jurídicos como agentes da política de enfrentamento ao tráfico de pessoas.

A relevância jurídica é verificada nas várias violações aos direitos humanos promovidas pelas ações que envolvem o tráfico de seres humanos. Talvez não haja violação aos direitos humanos mais ampla, que mais reafirme a necessidade de reconhecer os direitos humanos como indivisíveis.

\footnotetext{
${ }^{4}$ O Decreto 56.508, de 09/12/2010 alterou o nome do Comitê, que originalmente, na redação do Decreto 54101 de 12/03/2009 era denominado Comitê Interinstitucional de Prevenção e Enfrentamento ao Tráfico de Pessoas.

${ }^{5}$ Referenciados neste trabalho também como Comitês Regionais ou CRIPETPs.

${ }^{6}$ Decreto 57.368, de 26/09/2011.

${ }^{7}$ Também referenciado no presente trabalho como Comitê ou CEIPETP.
} 
No tráfico de pessoas o Direito pode ser encontrado no campo repressivo, com a atuação do Direito Penal, no Direito Internacional podemos encontrar a base para a adesão do Brasil no sistema internacional de proteção, legitimado pelo Protocolo de Palermo, o Direito do Trabalho aparece como ramo fundamental para a proteção das vítimas da exploração do trabalho, o Direito Constitucional como norteador das políticas públicas, os Direitos Humanos como referencial que atua como uma orientação transversal de todos os demais ramos do Direito.

O Direito aparece também na atuação dos profissionais jurídicos. Neste viés é que este trabalho busca e tem como objetivo principal analisar a percepção que os juristas têm das vítimas, bem como apontar como esses profissionais se percebem como agentes políticos, qual sua afetação/implicação com as políticas de direitos humanos. Entendemos que tornar visível essa percepção pode, por um lado, apontar caminhos para políticas públicas mais atentas ao cuidado e a proteção das vítimas, possibilitando a elaboração de protocolos de conduta que respeite a subjetividade dos sujeitos $\mathrm{e}$, por outro, trazer à luz a necessidade/possibilidade de capacitar os profissionais para uma prática mais atenta aos valores da pessoa, ao respeito aos direitos humanos, que propicie uma conduta menos preconceituosa e estigmatizante. A análise com enfoque em Direitos Humanos ${ }^{8}$ não exclui a de outros ramos do Direito, como Direito do Trabalho, Direito Penal e Direito Internacional.

Quanto a importância em desenvolver uma pesquisa que promova uma contribuição original à ciência jurídica, realizamos uma consulta ao Banco de Teses da Capes (CAPES, 2013) e localizamos quatro teses e 39 dissertações sobre o tema, cadastrados entre 2004 e 2013, utilizando os seguintes descritores: tráfico humano, tráfico de seres humanos, tráfico de pessoas. Das três teses localizadas, duas foram realizadas em Programas de Pós-Graduação em Direito, sendo uma delas realizada no programa de pós-graduação da Faculdade de Direito da Universidade de São Paulo (NOVAIS, 2008), com ênfase em Direito do Trabalho. Dessas disssertações e teses, pela leitura de seus resumos, não verificamos nenhum trabalho que tivesse como sujeito os profissionais do direito

\footnotetext{
${ }^{8}$ Apesar do seu caráter transversal, trataremos neste trabalho os Direitos Humanos como ramo do Direito.
} 
envolvidos nas políticas sobre o tema ou que investigasse o olhar desses profissionais a respeito das vítimas.

Para darmos concretude a este trabalho, optamos por apresentá-lo da seguinte maneira. Inicialmente, fizemos uma explanação a partir de uma reflexão sobre a emergência da proteção dos direitos humanos, da inserção do Brasil no sistema internacional de proteção e da sensibilidade a esses direitos alcançada nos últimos anos. Conceituamos políticas públicas para apresentá-las como importante instrumento para a concretização dos direitos humanos. Trouxemos à tona a importância dos profissionais do direito como sujeitos ativos na efetivação das políticas públicas. Finalizamos essa primeira parte evidenciando a necessária reflexão sobre universalismo e relativismo cultural, temas que entendemos fundamentais para uma análise do olhar sobre o outro, aqui, no caso, o olhar dos profissionais do direito sobre os sujeitos envolvidos na política de enfrentamento ao tráfico de pessoas.

Em seguida, esclarecemos alguns pontos acerca do nosso tema central, apresentando o conceito de tráfico de pessoas, as violações aos direitos provocadas por essa prática criminosa e a incorporação pelo Brasil do Protocolo de Palermo, com a subsequente adoção da política e do Plano Nacional de Prevenção e Enfrentamento ao Tráfico de Pessoas. Ressaltamos o crescimento da produção acadêmica, de pesquisas e relatórios oficiais sobre o tema e a aparente controvérsia entre os dados apresentados nesses trabalhos.

Na sequência, apresentamos o problema e suas delimitações. Observamos que é necessário um olhar sobre os dados e também sobre as ações de combate, prevenção e atendimento às vítimas do tráfico de pessoas. Com isso, apresentamos a delimitação do tema: por que tráfico de pessoas e por que São Paulo? Além desses destacamos a importância de uma abordagem interdisciplinar sobre o tema. Em seguida, apresentamos a possibilidade de diálogo entre os Direitos Humanos e a Psicologia Social.

O método então é apresentado na sequência. Entendemos ser fundamental uma explanação cuidadosa sobre o método, por termos utilizado um referencial teórico não usual nas teses em Direito. Por esta razão, optamos por 
especificar a Teoria das Representações Sociais como referencial teórico, fazendo uma breve explicação sobre o conceito e sobre as razões de sua escolha como referencial para a coleta e análise dos dados. Definimos também de maneira pormenorizada as etapas seguidas para alcançar os objetivos deste trabalho, desde a coleta de dados até a apresentação e a análise dos mesmos. Neste momento, explicamos o critério de escolha dos sujeitos participantes da pesquisa, bem como a seleção do instrumento de coleta de dados e a forma que escolhemos para apresentar e analisar os dados.

Esta explicação se faz necessária também porque optamos por apresentar os dados e analisá-los num mesmo momento. Entendemos que apresentar os dados e trazer a análise para o mesmo capítulo nos possibilitou aproximar os elementos externos, trazidos pela revisão bibliográfica, à reflexão sobre o conteúdo coletado nas entrevistas. Isso foi fundamental para construirmos um texto mais coeso e funcional onde os dados das entrevistas e os dados da revisão bibliográfica se mesclam, formando um todo, num diálogo que permite uma análise mais fecunda.

Após a apresentação e análise dos dados, retomamos os objetivos e buscamos, a partir de uma reflexão pontual, conduzir a uma construção ou desconstrução das expectativas apresentadas ao longo do trabalho, tecendo uma trama em que os elementos de análise propostos inicialmente pudessem dialogar entre si, construindo a rede interdisciplinar que possibilitou unir Tráfico de Pessoas, Profissionais do Direito e Políticas Públicas. E, por fim, as considerações finais. 


\section{2 - A EMERGÊNCIA DA PROTEÇÃO DOS DIREITOS HUMANOS - COLOCANDO OS DIREITOS HUMANOS EM PAUTA}

\section{(...) Diretos Humanos constituem o ideal comum a ser atingido por todos os povos e todas as nações, com o objetivo de que cada indivíduo e cada órgão da sociedade (...), se esforce, através do ensino e da educação, por promover o respeito a esses direitos e liberdades ${ }^{9}$}

A Era Moderna, entre outras coisas, foi o nascedouro do processo de conquistas de direitos humanos. A partir do século XVIII, com a Declaração da Virgínia (1776, EUA) e a Declaração dos Direitos do Homem e do Cidadão (1789, França), os direitos humanos se destacam, mas ainda como um anseio isolado dos povos. É somente a partir da metade do século XIX, com o Direito Humanitário, a luta contra escravidão e os direitos do trabalhador assalariado, que os direitos humanos começaram a ganhar dimensão internacional. O processo de internacionalização dos Direitos Humanos se desenvolve de forma mais ampla com o fim da $2^{\text {a }}$ Guerra Mundial (COMPARATO, 2008).

As atrocidades cometidas nesse conflito mostraram a necessidade de garantir valor supremo à dignidade humana. A Declaração Universal dos Direitos Humanos e a Convenção Internacional sobre a Prevenção e Punição do Crime de Genocídio, ambas de 1948, constituem os marcos inaugurais da nova fase, marcada pela internacionalização dos direitos humanos.

Vários pactos e tratados se seguiram - tanto globais quanto regionais, de alcance geral ou específico, preconizando a primazia dos direitos humanos e da dignidade da pessoa humana. Em todos os documentos internacionais há uma orientação expressa de que os países signatários incorporem em sua legislação interna o primado desses direitos como princípio norteador de sua ação em âmbito internacional e nacional.

O Brasil, após o ostracismo democrático provocado pela ditadura militar, vive, desde o final da década de 70 do século $X X$, uma nova fase no que tange ao

\footnotetext{
${ }^{9}$ Inspirado no tópico que proclama a Declaração Universal dos Direitos Humanos.
} 
reconhecimento e promoção dos direitos humanos. Ainda na ditatura, manifestações populares, sindicais, estudantis, ganharam força tendo como bandeira os direitos humanos. Os movimentos avançaram e ganharam dimensão reivindicatória estabelecendo pressão para que esses direitos entrassem na pauta política. Com a promulgação da Constituição Federal de 1988 (BRASIL, 1988), o Brasil estabelece como um dos fundamentos da República Federativa do Brasil a dignidade da pessoa humana (art. 1ํ, III) e, em seu artigo 4은, II, define que 0 Brasil se rege nas relações internacionais pelo princípio da prevalência dos Direitos Humanos.

Com essa nova postura, o Brasil passou, a partir da década de 90 do século passado, a ingressar de maneira incisiva no sistema internacional de proteção de direitos humanos, promovendo a ampla ratificação de tratados que envolvem essa temática no âmbito internacional. Importante salientar a participação da sociedade civil organizada no processo de abertura política no contexto da ditadura militar, participação essa sustentada e justificada pela defesa de direitos. A Constituição Federal de 1988, denominada a "Constituição Cidadã", mostrou-se inovadora para a realidade brasileira, até então marcada pela opressão e negativa de direitos.

Sem dúvida, vivemos um momento em que a sensibilidade à consecução dos direitos humanos foi formalmente acolhida. O grande número de tratados, pactos, declarações, convenções em nível internacional e a positivação desses direitos nas constituições de diversos países, promoveram a sua formalização, mas não os efetivaram. E uma questão que se impõe é: até que ponto a excessiva formalização dos direitos humanos de fato contribui para a sua concretização, para a sua adequação às especificidades?

Ferraz Jr. (1990), faz uma reflexão acerca da trivialização dos Direitos Humanos. Para ele, os direitos humanos se tornaram triviais, não em seu conteúdo, mas ficaram triviais "na proporção em que eles proliferam, difundem-se e se alteram." (FERRAZ JR., 1990, p. 111). Não que os direitos humanos em si se tornam triviais, mas a "jurisdicidade de seu sentido se torna trivial". Na perspectiva de que o direito é colocado como mais um bem na sociedade de consumo, o autor entende que 
os direitos do homem, ao manterem sua condição de núcleo básico da ordem jurídica, nem por isso deixam de ser objetos descartáveis de consumo, cuja permanência, não podendo mais assentar-se na natureza, no costume, na razão, na moral, passa a basear-se apenas na uniformidade da própria vida social, da vida social moderna, com sua imensa capacidade para a indiferença. Indiferença quanto ao que valia e passa a valer, isto é, aceita-se tranquilamente qualquer mudança. Indiferença quanto à incompatibilidade de conteúdos, isto é, aceita-se tranquilamente a inconsistência e se convive com ela. Indiferença quanto às divergências de opinião, isto é, aceita-se uma falsa ideia de tolerância, como a maior de todas as virtudes. (FERRAZ JR., 1990, P. 112)

Entendendo que "trivial significa alta indiferença em face das diferenças", aponta que a trivialização leva a uma neutralização valorativa dos direitos humanos, o que criam a impressão de universalidade construída a partir de certo consenso. A positivação leva à aceitação dos direitos como invariante, trazendo a sensação de imutabilidade para uma ordem que é mutável. Isso leva a uma ideia de inflexibilidade dos direitos humanos, permitindo apenas uma discussão técnico-instrumental, favorecendo a mudança de valores, como se a mudança de valores não levasse a uma mudança de direitos.

Não se pode negar que a trivialização dos direitos humanos a partir da sua positivação abre espaço para uma acomodação, um afastamento e que o reconhecimento de direitos não leva necessariamente a sua efetivação, mas também não se pode negar que no mundo moderno, sem a positivação, os direitos humanos não entrariam nas pautas e políticas de governo. No entendimento de Bittar (2009)

Ainda que trivializados, estes direitos são constitutivos de obrigações mínimas em face do Estado, limitadores arbitrários, certamente não suficientes por si mesmos, e instrumentos de busca permanente no plano dos direitos, que fazem da realidade sociopolítica contemporânea uma permanente reflexão sobre a sua incapacidade de tornar efetivos tais direitos. (p. 285).

Bobbio (1992), em seu clássico "A Era dos Direitos", vê a positivação como a última de três fases do processo de universalização dos direitos humanos. Segundo o autor as declarações nascem como teorias filosóficas e nesta fase as 
primeiras afirmações dos direitos do homem são pura e simplesmente a expressão de um pensamento individual: são universais em relação ao conteúdo (dirige-se a um homem racional fora do espaço e do tempo), mas tem eficácia limitada, vez que são propostas para um futuro legislador.

Num segundo momento há uma passagem da teoria à prática, do direito pensado para o realizado. Ganha-se em concreticidade mas perde-se em universalidade. Os direitos são protegidos, mas valem somente no Estado que os reconhece. Na terceira fase, marcada pela Declaração Universal dos Direitos Humanos de 1948, a afirmação dos direitos é universal e positiva. Trata dos direitos do homem enquanto cidadão do mundo.

Assim, os direitos do homem nascem como direitos naturais universais, desenvolvem-se como direitos positivos particulares, para finalmente encontrarem sua realização como direitos positivos universais. Mas a Declaração Universal é vista pelo autor apenas como o primeiro passo. Aponta a importância de reconhecer-se que a Declaração traduz os anseios de sujeito datado, de um homem histórico. E como histórico, os anseios e as demandas do homem estão em constante transformação.

2.1 - Direitos Humanos, Políticas Públicas e Judiciário: onde os Profissionais do Direito se encontram

Toda pessoa tem direito a receber dos tribunais nacionais competentes remédio efetivo para os atos que violem os direitos fundamentais que lhe sejam reconhecidos pela constituição ou pela lei ${ }^{10}$

Ainda que tardiamente, o Brasil aderiu a esse processo de positivação. A maciça adesão aos tratados internacionais de Direitos Humanos na década de 1990 coloca o Brasil como protagonista. O país assume gradativamente a

\footnotetext{
${ }^{10}$ Artigo VIII, Declaração Universal dos Direitos Humanos.
} 
proteção dos direitos humanos, ratificando tratados, promulgando leis específicas para tratar do assunto, desenvolvendo políticas públicas. Verificamos também, nas últimas décadas, uma valorização dos direitos humanos no Brasil, o que pode ser comprovado pelo aumento de casos levados à apreciação do Supremo Tribunal Federal (STF). Segundo Ramos (2011), podemos observar que "o Direito Internacional dos Direitos Humanos não é mais uma menção episódica na jurisprudência dos últimos anos do STF, existindo hoje inúmeros precedentes seus que invocam normas internacionais de direitos humanos" (RAMOS, 2011, p. 03).

O mesmo autor (2013) em análise sobre a necessidade dos países adequarem a interpretação de seus tribunais à jurisprudência dos tribunais internacionais, para que haja coerência entre o acordado e o efetivado, destaca que

as normas de direitos humanos previstas em leis internas, Constituições e tratados internacionais são apenas um ponto de partida e nunca um ponto de chegada para o intérprete, pois cabe sempre averiguar a real interpretação e configuração normativa dada pelos tribunais (RAMOS, 2013, p. 29).

Importante ressaltar que o STF ainda profere decisões contrárias ao Direito Internacional dos Direitos Humanos, como fez ao declarar a constitucionalidade da Lei de Anistia (Lei 6683/79), em maio de 2010. A Corte Interamericana de Direitos Humanos, em dezembro de 2010, no caso Lund e outros (Guerrilha do Araguaia), concluiu que o Brasil é responsável pela desaparição forçada de 62 pessoas, ocorrida entre os anos de 1972 e 1974 na região do Araguaia e dispôs que o Estado brasileiro investigue e responsabilize penalmente os fatos referentes a esse caso.

Ainda para Ramos (2013), é fundamental que se estruture uma teoria geral dos direitos humanos na ordem internacional, para "evitar que a proteção de direitos humanos na ordem internacional converta-se em conjunto de decisões inorgânicas, desconectadas, fruto do decisionismo judicial e reveladora de perigosa insegurança jurídica" (p. 30). 
A judicialização dos direitos humanos acaba por exigir o protagonismo do Judiciário nesta seara. Não se pode negar que o Judiciário passa a ser acionado a partir do final dos anos de 1970 graças à iniciativa de movimentos sociais e políticos no sentido de conscientizar os setores sociais menos favorecidos de seus direitos e com isso estimulando-os a movimentar o Judiciário (FARIA, 1994a). A adição dos direitos sociais e econômicos à constituição é outro fator que favorece o aumento das demandas ao judiciário. Segundo Santos, Marques e Pedroso (1995),

A consagração constitucional dos direitos sociais e econômicos, tais como o direito ao trabalho e ao salário justo, à segurança no emprego, à saúde, à educação, à habitação, a segurança social significa, entre outras coisas, a juridificação da justiça distributiva. A liberdade a proteger juridicamente deixa de ser um mero vínculo negativo para passar a ser um vínculo positivo, que só se concretiza mediante prestações do Estado. (1995, p. 11)

A tensão entre a justiça social e a igualdade formal exige um posicionamento jurídico e político. Sendo direitos positivos, exigem uma ação estatal "e dessa gestão são incumbidos, ainda que de modo diferente, todos os órgãos e poderes do Estado" (SANTOS; MARQUES; PEDROSO, 1995, p. 11). Para Faria, o judiciário brasileiro enfrenta o dilema de adequar um sistema jurídico-positivo às

condições de vida de uma sociedade com $40 \%$ de seus habitantes vivendo abaixo da linha de pobreza, em condições subumanas, na consciência de que a atividade judicial extravasa os estreitos limites do universo legal, afetando o sistema social, político e econômico em sua totalidade. (FARIA, 1994, p. 48)

Para Maria Paula Dallari Bucci (2006) "A necessidade de compreensão das políticas públicas como categoria jurídica se apresenta à medida em que se busca normas de concretização dos direitos humanos, em particular dos direitos sociais" (p. 3). Para uma definição de políticas públicas, recorremos a Massa-Arzabe (2006), que, fazendo uma síntese de vários autores, define-as como

[...] conjunto de programas e de ação governamental estáveis no tempo, relacionalmente moldadas, implantadas e avaliadas, dirigidas à realização de direitos e de objetivos 
social e juridicamente relevantes, notadamente plasmados na distribuição e redistribuição de bens e posições que concretizem oportunidades para cada pessoa viver com dignidade e exercer seus direitos, assegurando-lhes recursos e condições para a ação, assim como a liberdade de escolha para fazerem uso desses recursos. (MASSAARZABE, 2006, p. 63).

Desse modo, as políticas públicas são os instrumentos adequados para a concretização dos direitos humanos. Para Bucci (2001), à medida que o conteúdo jurídico da dignidade humana amplia-se conforme "novos direitos vão sendo reconhecidos e agregados ao rol dos direitos fundamentais" (p. 8), a consecução de tais direitos torna-se cada vez mais uma questão complexa,

[...] a qual vem demandando um aparato de garantias e medidas concretas do Estado que se alarga cada vez mais, de forma a disciplinar o processo social, criando formas que neutralizem a força desagregadora e excludente da economia capitalista e possam promover o desenvolvimento da pessoa humana. (BUCCl, 2001, p. 08)

Tendo as políticas públicas como fundamentais na concretização dos direitos humanos, não podemos deixar dar relevo à importância dos profissionais do direito na consecução desse fim. Vivemos uma época em que a defesa dos direitos humanos deixa de ser caso fortuito para tornar-se preocupação corrente dos profissionais do direito. Sejam advogados, defensores públicos, juízes, promotores, delegados de polícia, o tema permeia a ação cotidiana, sobretudo caso esses profissionais estejam envolvidos em políticas públicas que envolvam a proteção dos direitos humanos.

Em trabalho anterior (FRINHANI, 2004), concluímos pela "urgência em se estabelecer novos paradigmas para as práticas dos profissionais do direito, sejam advogados, promotores ou juízes", a partir de uma formação em que "o ensino do Direito deve ganhar uma dimensão mais humanista e ética, o que contribuiria para a consecução de uma sociedade justa e igualitária" (p. 134). Retomamos essa necessidade nesse trabalho, reconhecendo no profissional do direito importante agente de transformações e possível pilar nas estratégias de consciência da cidadania dos sujeitos vitimados pelas violações dos direitos humanos. 
A reflexão neste trabalho sobre a atuação do judiciário e as políticas públicas é importante uma vez que no judiciário todas as profissões jurídicas se encontram - o Ministério Público como "instituição permanente, essencial à função jurisdicional do Estado, incumbindo-Ihe a defesa da ordem jurídica, do regime democrático e dos interesses sociais e individuais indisponíveis" (CF, artigo 127, caput); A Defensoria Pública, como "instituição essencial à função jurisdicional do Estado, incumbindo-Ihe a orientação jurídica e a defesa, em todos os graus, dos necessitados, na forma do art. $5^{\circ}$, LXXIV" (CF, art, 134); Advogado, reconhecido como "indispensável à administração da justiça" (CF, art. 133).

Como bem frisa Bucci (2006), o art. 5, XXXV, da Constituição Federal torna inquestionável a possibilidade de uma política pública ser submetida ao Judiciário, ao dispor que "A Lei não excluirá da apreciação do Poder Judiciário lesão ou ameaça a direito". As ações coletivas, a ação civil pública, o inquérito civil, o termo de ajustamento de conduta são alguns dos instrumentos possíveis para mobilizar o judiciário com vistas à concretização de políticas públicas.

A autora chama a atenção para a possibilidade da ocorrência da judicialização da política levar à concorrência entre direitos, e também o risco da iniciativa do Ministério Púbico e do Judiciário levarem a uma inércia do Poder Executivo. No entanto, ressalta que mesmo que haja este risco, "não deve ser menosprezda a importância das ações civis públicas para a inclusão dos direitos fundamentais no cenário judicial" (BUCCl, 2006, p. 33).

Quando o Estado acolhe a dimensão social dos direitos humanos, assume a responsabilidade de agir no sentido de reconhecer e garantir estes direitos. Este debate envolve necessariamente a reflexão sobre a indivisibilidade dos direitos humanos, princípio constantemente desprezado quando os direitos que estão em pauta são os direitos sociais.

Segundo o item 5 da Declaração e Programa de Ação de Viena (1993)

5. Todos os Direitos Humanos são universais, indivisíveis, interdependentes e interrelacionados. A comunidade internacional deve considerar os Direitos Humanos, globalmente, de forma justa e equitativa, no mesmo pé e com igual ênfase. Embora se deva ter sempre presente 0 
significado das especificidades nacionais e regionais e os diversos antecedentes históricos, culturais e religiosos, compete aos Estados, independentemente dos seus sistemas políticos, econômicos e culturais, promover e proteger todos os Direitos Humanos e liberdades fundamentais.

Apesar da disposição afirmada pela Declaração, o que se observa é ainda uma dificuldade em garantir a indivisibilidade dos direitos humanos quando os direitos sociais estão em questão. A fragilidade dos mecanismos de monitoramento dos direitos sociais, econômicos e culturais no sistema global tem sido objeto de debates no sentido da necessidade de garantir a justicialidade desses direitos. Segundo Piovesan (2003), "A preocupação básica é no sentido de assegurar justiciabilidade ou exigibilidade dos direitos econômicos e sociais, ou ao menos de alguns desses direitos" (p. 102).

Em análise sobre a incorporação de tratados internacionais, Comparato disserta sobre a diferença de tratamento dada aos direitos civis e políticos quando comparados com os direitos econômicos e sociais. Aponta que quando se trata dos direitos civis e políticos, a discriminação não é aceita, o que não ocorre com os direitos econômicos e sociais. Para o autor, a jusdicialidade dos direitos sociais e econômicos é fundamental para que se evite a vulnerabilidade dos segmentos mais carentes.

Há que se submeter à justiciabilidade decisões governamentais e de organismos financeiros internacionais que, à guisa de resolver problemas econômicos, condenam ao empobrecimento, ao desemprego e à fome se não a médio ou longo prazo à miséria e à morte, milhares de seres humanos. Se é verdade que a vigência de muitos direitos econômicos e sociais é de realização progressiva, também e certo que tal vigência requer medidas imediatas por parte dos Estados. (CANÇADO TRINDADE, 1996, p. 710)

O Pacto de Direitos Civis e Políticos em seu artigo 2º 1 , dispõe sobre o compromisso dos Estados Partes em adotar medidas de maneira progressiva, até o máximo de seus recursos disponíveis. In verbis

Art. 2으. 1. Cada Estados Partes do presente Pacto comprometem-se a adotar medidas, tanto por esforço próprio como pela assistência e cooperação internacionais, 
principalmente nos planos econômico e técnico, até o máximo de seus recursos disponíveis, que visem assegura, progressivamente, por todos os meios apropriados, o, pleno exercício e dos direitos reconhecidos no presente Pacto, incluindo, em particular, a adoção de medidas legislativa. (ONU, 1969)

A adoção progressiva e nos limites dos recursos orçamentários disponíveis não deve ser compreendida como obstáculo à concretização dos direitos em tela. A sua adoção deve se dar em um período de tempo razoavelmente curto e é vedado aos Estados retrocederem no campo da implementação dos direitos econômicos, sociais e culturais. É a chamada cláusula da "proibição do retrocesso social" (PIOVESAN, 2003). Deste modo, é necessário reconhecer que o Judiciário é órgão importante no controle, mediante ação, do cumprimento destes direitos.

Segundo Campilongo (1994)

"[...] além de suas funções usuais, cabe ao Judiciário controlar a constitucionalidade e o caráter democrático das regulações sociais. Mais ainda: o juiz passa a integrar 0 circuito de negociação política. Garantir as políticas públicas, impedir o desvirtuamento privatista das ações estatais, enfrentar o processo de desinstitucionalização dos conflitos - apenas para arrolar algumas hipóteses de trabalho significa atribuir ao magistrado uma função ativa no processo de afirmação da cidadania e da justiça substantiva. (1994, p. 49)

Para o autor, é necessário rever o papel do Judiciário, papel este que não mais pode ser restrito à aplicação do direito, ação esta que deve ser combinada com a escolha de valores e aplicação de modelos de justiça, cabendo aos juízes também a responsabilidade da distribuição dos recursos. $O$ argumento de que os direitos sociais, por exigirem uma ação do Estado, encontram óbice no orçamento e que sendo questão política não caberia ao judiciário deliberar por não ser um poder eleito pelo povo (BARBOZA; KUZICKI, 2012), deve ser questionado. O princípio da reserva do possível tem sido usado como razão para limitar a atuação do Poder Judiciário nas políticas públicas diante de quadros de escassez de recursos.

Ocorre que a falta de vontade política e o grande fosso social que separa o Brasil impede que grande parte da população usufrua dos direitos sociais. Como 
definir o que é 'possível' quando houver uma distribuição distorcida dos orçamentos em cada ente federado (KRELL, 2002), e quando estivermos diante de recursos distribuídos de maneira equivocada? Diante da dificuldade em haver uma definição prévia do 'possível', é forçoso pensar que o Poder Judiciário deverá ser o poder adequado para controlar o cumprimento das políticas públicas uma vez que estas são o instrumento constitucional a ser usado para a efetivação dos direitos fundamentais (BARBOZA; KUZICKI, 2012). Isto é, na inércia dos poderes políticos e sendo acionado, o Judiciário deverá atuar e dizer do direito.

Elucidativo o voto do Ministro Celso de Mello na decisão de Agravo Regimental no Recurso Extraordinário n. 410.715-5, no que tange aos limites e necessidade de atuação do Poder Judiciário nas políticas públicas. Em trecho da ementa do acórdão:

Embora resida, primariamente, nos Poderes Legislativo e Executivo, a prerrogativa de formular e executar políticas públicas, revela-se possível, no entanto, ao Poder Judiciário, determinar, ainda que em bases excepcionais, especialmente nas hipóteses de políticas públicas definidas pela própria Constituição, sejam estas implementadas pelos órgãos estatais inadimplentes, cuja omissão - por importar em descumprimento dos encargos político-jurídicos que sobre eles incidem em caráter mandatório - mostra-se apta a comprometer a eficácia e a integridade de direitos sociais e culturais impregnados de estatura constitucional. A questão pertinente à "reserva do possível". ${ }^{11}$

Não se pode desprezar que, apesar das questões políticas, que muitas vezes dificultam a consecução de direitos alegando falta de previsão orçamentária, desconsiderando o caráter indivisível dos direitos humanos, os debates, a partir da segunda metade do século $\mathrm{XX}$, levaram a uma reflexão acerca da dignidade da pessoa humana e à necessidade do respeito a essa dignidade. Não se pode também desprezar que ao mesmo tempo em que a incorporação de novos direitos estende o conteúdo jurídico da dignidade, novas formas de opressão e subjugação do indivíduo ainda são amplamente reproduzidas pelo estado e pela economia.

\footnotetext{
${ }^{11}$ Disponível em http://www.acaoeducativa.org.br/portal/images/stories/pdfs/lj1 34.pdf, acesso em 28/10/2013. Publicado no Diário da Justiça em 3-2-2006.
} 


\section{2 - As discussões sobre o Universalismo e o Relativismo Cultural: há lugar para um consenso?}

\section{Todas as pessoas nascem livres e iguais em dignidade e direitos. São dotadas de razão e consciência e devem agir em relação umas às outras com espírito de fraternidade ${ }^{12}$}

Mas, apesar da ampliação da positivação dos direitos e dos constantes debates, o que percebemos é um grande paradoxo: por um lado, os direitos humanos são tratados como direitos de grupos desvalorizados, que não deveriam receber respeito e proteção, como é o caso da população carcerária, como nos permite inferir a reflexão trazida por Caldeira (1991) e por Soares (1998), sobre a equiparação dos direitos humanos a direito de bandido. Segundo as autoras, essa vinculação é feita no período pós ditadura militar, visto que no período repressivo, os Direitos Humanos foram utilizados como argumento de defesa pelos presos políticos e com o fim da ditadura acabaram sendo relacionados a direito de presos, os quais, em sua maioria, são das classes populares. Esta vinculação acabou por afastar a defesa dos Direitos Humanos dos interesses da classe média (como o foi no período da Ditadura quando a maioria dos presos políticos eram deste segmento social). A opinião pública acaba por ser envolvida pelo discurso que favorece a vinculação entre Direitos Humanos e direitos de bandidos.

Por outro lado, vê-se a dignidade humana como restrita a grupos valorizados.

[...] Parece uma brutal contradição, mas na verdade não é. Isso porque, paralelo ao crescimento do discurso dos direitos humanos, o corolário de que os mesmos só se aplicam a certos grupos de pessoas, o dos "humanos direitos", também ganhou uma força incrível (COLARES, 2004, p. 07).

Há uma tentativa de relativizar o acesso aos direitos humanos aos indivíduos que se adequem a um padrão social estabelecido pelos grupos

\footnotetext{
${ }^{12}$ Artigo I, Declaração Universal do Direitos Humanos.
} 
dominates. A expressão "direitos humanos para humanos direitos" tem sido utilizada de maneira preconceituosa visando a delimitar o exercício dos direitos humanos aos humanos que se comportam dentro de um padrão reto, direito, assim considerado por determinado grupo. Paglione (2010) discute o equívoco desta expressão.

Nesse embate entre quem seriam esses "humanos direitos" (expressão que rechaço) é necessário que o item 5 da Declaração de Viena seja retomado. Além da indivisibilidade, a universalidade aparece como característica a ser alcançada na proteção dos direitos humanos. Segundo referido item, os Direitos Humanos devem ser considerados globalmente, respeitando-se as especificidades nacionais e regionais, os diversos antecedentes históricos, culturais e religiosos (ONU, 1993).

A universalidade dos direitos humanos deve ser compreendida no sentido de que são de titularidade de todos os indivíduos. Para Bobbio (1992) a ideia de universalidade veio após a Declaração Universal dos Direitos Humanos, momento em que se pode dizer que a humanidade estabeleceu valores comuns e que estes valores pressupõem uma universalidade, "no sentido em que o universal significa não algo dado objetivamente, mas algo subjetivamente acolhido pelo universo dos homens" (BOBBIO, 1992, p. 28).

De lá para cá, vários pactos e tratados foram estabelecidos, em âmbito global e regional. Além disso, pudemos verificar a positivação dos direitos humanos nos textos constitucionais. Para Soares (1998), nos países em que mais se violam os direitos humanos a positivação acaba por favorecer sua defesa. Este excesso de positivação continua sendo objeto de reflexão de Ferraz JR. (2007), ao debater sobre os paradoxos modernos: adequar a liberdade a ideias e valores universalmente reconhecidos e legitimados.

Reside aí a raiz provável do paradoxo de uma sociedade, de um lado, obsessivamente preocupada em definir e proclamar uma lista crescente de direitos humanos, mas impotente, de outro, para fazer descer esses direitos do plano de um formalismo abstrato e inoperante, e levá-los a uma efetivação concreta nas instituições e práticas sociais. $\mathrm{Na}$ verdade, entre a universalidade do direito e as liberdades 
singulares a relação permanece abstrata e, no espaço dessa abstração, desencadeiam-se formas muito reais de violência que acabam por consumar a cisão entre Ética e Direito no mundo contemporâneo: aquela degradada em moral do interesse e do prazer, esse exilado na abstração da lei ou confiscado pela violência ideológica (FERRAZ JR, 2007, p. 11).

Entre a universalidade e o relativismo, fundamental colocar a dignidade humana como ponto central da proteção dos direitos humanos. Mas, como classificar dignidade humana e como "universalizar" a dignidade diante de sociedades tão diversas e complexas? A dignidade da pessoa humana como norte justifica a interferência externa quando da violação de direitos humanos, uma vez que direitos humanos são direitos sem fronteiras e por isso devem superar as fronteiras jurídicas e a soberania dos Estados.

O fato de a Constituição Federal ter estabelecido a dignidade humana (artigo 1ํ, III, CF) como fundamento da República Federativa do Brasil, faz com que os debates sobre direitos humanos necessariamente passem por ela. Filósofos, juristas e sociólogos reiteradamente analisam qual a dimensão desta dignidade. Por qual razão determinados direitos devem ser respeitados universalmente e o que fundamenta este critério tem sido objeto de estudo de BOBBIO, 1992; SOARES (1998); COMPARATO (2008); RAMOS (2013), entre outros. A dignidade humana constantemente se mostra como a razão-maior que legitima a proteção dos Direitos Humanos.

Para Sarlet (2005), apesar de ser necessária a discussão e definição do que seja dignidade humana, esta definição parece difícil, uma vez que se trata de um conceito impreciso, de contornos vagos, ambíguo e poroso, polissêmico. A maior dificuldade reside no fato de dignidade humana não dizer respeito a aspectos específicos do indivíduo, mas de uma qualidade inerente a todo ser humano. A dignidade humana é considerada por alguns como o valor próprio que identifica o ser humano como tal (SARLET, 2005).

Mas, considerar a dignidade como o "valor próprio que identifica o ser humano como tal", exige que se reconheça uma unicidade que identifique os indivíduos como membros de uma mesma "coletividade" e por isso merecedores 
do mesmo respeito, dignos de serem tratados pelo prisma da igualdade. Ocorre que este tratamento que reconhece uma igualdade formal, uma igualdade genérica e abstrata, não contempla o ser humano na sua especificidade, na sua concreticidade.

Sabemos, entretanto, que o homem é histórico e seus direitos também. Na clássica citação de Bobbio (1992) "os direitos não nascem todos de uma vez. Nascem quando devem ou podem nascer". (p. 06). Nascem quando o poder do homem sobre o homem cria novas ameaças à liberdade do indivíduo (liberdades negativas) ou permite novos remédios para suas necessidades (liberdades positivas).

Considerados como históricos, os Direitos Humanos são mutáveis, suscetíveis de transformação e ampliação. O ser humano, concebido como um ser concreto necessita de uma contextualização sócio histórica. Definições genéricas e abstratas não contemplam as especificidades humanas. O Homem concreto é o Homem marcado por um contexto sócio histórico, por uma questão socioeconômica, por características pessoais de raça, etnia, gênero, orientação sexual, idade.

O ser humano considerado em sua concretude pode ser assim compreendido para que the sejam garantidos direitos reconhecidos exatamente por sua especificidade (reconhecimento da especificidade do ser criança, ser mulher, ser idoso e assim ter reconhecidos direitos específicos destes grupos), mas, por outro lado, também pode ser assim reconhecido como uma forma de the serem negados direitos, uma vez que enquadrados como diferentes. Isto porque a ideia da diferença pode vir acoplada à ideia do não-pertencimento; não-pertencer pode significar não ser reconhecido como titular de direitos.

Nas discussões sobre multiculturalismo e políticas de reconhecimento, Honneth (1992) e Taylor (1994) estabelecem relação entre reconhecimento e identidade. Segundo Taylor (1994), identidade seria "a maneira como uma pessoa se define, como é que as suas características fundamentais fazem dela um ser humano" (p. 46). Ainda segundo Taylor (1994) 
O reconhecimento incorrecto não implica só uma falta do respeito devido. Pode também marcar as suas vítimas de forma cruel, subjugando-as através de um sentimento incapacitante de ódio contra elas mesmas. Por isso, o respeito devido não é um acto de gentileza para com os outros. É uma necessidade humana vital. (1994, p. 47)

Da mesma forma, para Honneth, o reconhecimento é fundamental para a construção de uma identidade plena:

nossa integridade é dependente (...) da aprovação ou reconhecimento de outras pessoas. A negação do reconhecimento (...) é prejudicial porque impede (...) que as pessoas tenham uma visão positiva de si mesmas - uma visão que é adquirida intersubjetivamente (1992, p. 188-9).

As discussões sobre direito à igualdade e diferença, universalidade e relatividade dos direitos humanos, serão, necessariamente, no momento atual, atravessadas pelas políticas multiculturais e pelas políticas de reconhecimento. $\mathrm{O}$ debate sobre quais grupos serão sujeitos a quais políticas podem permitir uma compreensão sobre quais políticas são as mais adequadas para a efetivação do ideal de justiça social e promoção da dignidade humana.

Na luta pelos direitos humanos o mais difícil de compreender e, portanto, defender, são os direitos de igualdade. A igualdade não é a uniformidade, mas o direito de ser reconhecido como igual na diferença, de não ser tratado de forma diferente em razão de alguma característica física, social, econômica, cultural. É cumprir o que preconiza conhecida frase de Boaventura de Sousa Santos "temos o direito a ser iguais quando a diferença nos inferioriza, temos o direito a ser diferentes quando a igualdade nos descaracteriza ${ }^{13}$.

O olhar para as diferenças pode ter um foco ora cultural, ora socioeconômico. Determinar qual diferença deve ser reconhecida e respeitada (cultura) e qual diferença deve ser eliminada ou diminuída (socioeconômica) pelo viés da redistribuição, pode ser o ponto de partida para a definição de políticas de fato comprometidas com a promoção da dignidade humana e com isso a defesa dos direitos humanos.

\footnotetext{
${ }^{13}$ Frase repedida em entrevista dada ao Jornal o Globo, acesso ao site feito em 29/10/2013, disponível em http://oglobo.globo.com/blogs/prosa/posts/2010/07/23/boaventura-de-sousa-santosfala-sobre-rap-global-310530.asp.
} 
Segundo Nancy Fraser, "Justiça, hoje, requer tanto redistribuição quanto reconhecimento; nenhum deles, sozinho, é suficiente" (FRASER, 2007, p. 103). Para a autora, o que se deve buscar é o reconhecimento cultural e a igualdade social, uma vez que a injustiça cultural está atrelada à injustiça econômica, assim como o contrário. As lutas por redistribuição se fundamentam na ideia de que a injustiça socioeconômica está enraizada na estrutura político-econômica e medidas contra isto podem ser a redistribuição de renda e a reorganização do trabalho, entre outras. Por outro lado, a luta por reconhecimento se vincula à ideia de cultura e as lutas contra a injustiça cultural buscam uma nova percepção social, destruindo padrões sociais de comportamento e interpretação preconceituosos e valorizando a diversidade cultural.

Para Fraser, o reconhecimento está essencialmente ligado à ideia de Justiça estando o não-reconhecimento atrelado a práticas discriminatórias institucionalizadas, no que difere de Honneth (2007), para o qual o reconhecimento está ligado à autorrealização individual, sendo 0 nãoreconhecimento analisado a partir das atitudes depreciatórias sofridas pelos indivíduos.

Gislene Santos (2010), em análise de texto de Honneth, conclui que o não reconhecimento poderia levar a conflitos sociais em razão do grande sentimento de injustiça e por levar à percepção de quebra do pacto social, por não garantir liberdade, propriedade e dignidade para todos. "A busca por reconhecimento evidenciaria que o pacto e as normas jurídicas e institucionais, que inicialmente $o$ assegurariam, foram somente 0 ponto de partida e a chegada não teria se efetivado" (SANTOS, 2010, p. 6).

Além das políticas de reconhecimento, podemos identificar as políticas multiculturais como aptas a lidar com as questões da igualdade e da diferença. Kymlicka (2007) identifica as políticas de reconhecimento contemporâneas como políticas multiculturais, que têm como objetivo oferecer alguma forma adicional de reconhecimento público ou algum suporte para a acomodação, reconhecimento de grupos étnicos, de identidades e de práticas. 
Ainda segundo esse mesmo autor, cada estado apresenta uma forma diferente de lidar com as demandas multiculturais. As formas como as minorias desejam ser reconhecidas e aceitas variam grandemente entre países, bem como entre diferentes minorias dentro do mesmo país. De qualquer modo, existem alguns princípios gerais que são comuns aos diferentes esforços por um Estado multicultural.

Para Bauman, o foco das ações em nome da dignidade da pessoa humana deve estar direcionado para políticas que promovam a justiça social: "As demandas por redistribuição feitas em nome da igualdade são veículos de integração, enquanto as demandas por reconhecimento em meros termos de distinção cultural promovem a divisão, a separação e acabam na interrupção do diálogo" (BAUMAN, 2003, p. 72), e poderemos levar a luta por reconhecimento ao precipício relativista.

Quando a luta por reconhecimento tiver como foco a distinção cultural e for colocada à força "na moldura da autoafirmação e da autorrealização", poderá expor seu potencial de combate, chegando, em último caso, ao genocídio. Se o foco for a justiça social, as reivindicações por reconhecimento podem se tornar um terreno fértil para o comprometimento mútuo e o diálogo significativo, que poderão levar a uma comunidade ética.

Misturar justiça distributiva com política de reconhecimento pode ser tomado como consequência natural da promessa de justiça social nas condições de modernidade líquida:

"(...) era da reconciliação com a perspectiva da coexistência
perpétua, exige a coabitação pacífica e caridosa; uma era
em que não se pode mais ter (ou mesmo querer ter) a
esperança de uma erradicação completa e radical da miséria
humana, seguida de uma condição humana livre de conflitos
e sofrimentos". (BAUMAN, 2003, p. 73 )

Para Boaventura de Sousa Santos (2003), o multiculturalismo busca explicar as tensões entre a diferença e a igualdade, entre a exigência de reconhecimento da diferença e de redistribuição que permita a realização da igualdade. Seriam necessárias iniciativas emancipatórias contra as reduções 
eurocêntricas de termos fundamentais (cultura, justiça...) procurando propor noções mais inclusivas e respeitadoras da diferença de concepções alternativas da dignidade humana. Como respeitar as diferenças (coletivo) e ao mesmo tempo garantir o direito à igualdade (indivíduo)? Como reinventar cidadanias que consigam ao mesmo tempo ser cosmopolitas e locais?

Segundo o autor, existem diferentes concepções de multiculturalismo. A expressão "designa, originalmente, a coexistência de formas culturais ou de grupos caracterizados por culturas diferentes no seio das sociedades modernas" (2003, p. 26), passando, com a rapidez da modernidade, a designar o modo de descrever as "diferenças culturais em um contexto transnacional e global" (idem, idem). $\mathrm{Na}$ diversidade de concepções, o multiculturalismo ganha vieses descritivos, quando se ocupa de descrever a multiplicidade de culturas e a interrelação das diversas culturas dentro do mesmo Estado-Nação, e também alcança a característica de projeto político de celebração ou reconhecimento dessas diferenças.

A sobreposição do multiculturalismo como descrição em detrimento do multiculturalismo como projeto suscita críticas conservadoras e progressistas (SOUSA SANTOS, 2003, p. 29). Apesar das críticas ao multiculturalismo, Boaventura de Sousa Santos entende que é possível que o multiculturalismo assuma uma direção emancipatória, no seu viés de projeto. Para o autor, visão emancipatória seria o reconhecimento da diferença e do direito à diferença e da coexistência ou construção de uma vida em comum além de diferenças de vários tipos. Seria a luta pela redistribuição e pelo reconhecimento no quadro da globalização hegemônica, por meio de uma globalização contra-hegemônica, que vê "nos direitos humanos uma arma de luta contra a opressão" (SOUSA SANTOS, 2003b, p. 440), em um projeto cosmopolita.

Na defesa de uma concepção multicultural dos direitos humanos, Sousa Santos (1997), acredita que um multiculturalismo emancipatório é possível a partir de um diálogo entre as culturas. Para ele, os direitos humanos não são universais na sua aplicação. 
Os direitos humanos têm que ser reconceptualizados como multiculturais. O multiculturalismo tal qual eu o entendo, é pré-condição de uma relação equilibrada e mutuamente potenciadora entre a competência global e a legitimidade local, que constituem os dois atributos de uma política contra-hegemônica de direitos humanos no nosso tempo (SOUSA SANTOS, 1997, p. 19)

Para Sousa Santos (2003), a construção de uma concepção multicultural dos direitos humanos emancipatória, contra-hegemônica e cosmopolita passa por uma transformação. Em síntese, esta transformação passa pelas seguintes premissas: superação do debate entre universalismo e relativismo cultural; todas as culturas possuem concepções de dignidade humana, mas nem todas elas explicitadas em termos de direitos humanos. Muitas vezes culturas diferentes dizem de maneiras diferentes, a mesma coisa, e é necessário que isso se esclareça; todas as culturas são incompletas e problemáticas nas suas concepções de dignidade humana; se são incompletas, as culturas deveriam reconhecer esta incompletude e aceitarem um diálogo intercultural. A concepção multicultural de direitos humanos nasceria desse diálogo e se daria a partir de uma hermenêutica diatópica. ${ }^{14}$

Enquanto esta transformação não se opera e não há um consenso sobre isso, a reflexão sobre quais grupos são vulneráveis às violações dos direitos humanos e quais as vítimas efetivas dessas violações passam a ser recorrentes. A negativa de direitos normalmente passa por uma negativa do sujeito e de suas peculiaridades. Um grupo vulnerável que tem merecido a atenção da comunidade internacional, seja pelo suposto rompimento de fronteiras do mundo globalizado, seja pelas graves violações aos seus direitos, é o grupo dos migrantes irregulares ou indocumentados que buscam melhores oportunidades em países estranhos. Fogem, muitas vezes, de uma situação de pobreza e marginalização que os tornam vulneráveis ao aliciamento, seja para transpor as fronteiras de seus Estados violando as leis migratórias, seja como vítimas de tráfico de pessoas.

\footnotetext{
14“'A hermenêutica diatópica baseia-se na ideia de que os topoi de uma dada cultura, por mais fortes que sejam, são tão incompletos quanto a própria cultura a que pertencem. Tal incompletude não é visível do interior dessa cultura, uma vez que a aspiração à totalidade induz a que se tome a parte pelo todo. O objectivo da hermenêutica diatópica não é, porém, atingir a completude - um objectivo inatingível - mas, pelo contrário, ampliar ao máximo a consciência de incompletude mútua através de um diálogo que se desenrola, por assim dizer, com um pé numa cultura e outro, noutra. Nisto reside o seu carácter diatópico." (SOUSA SANTOS, 2003b, p. 444)
} 


\title{
3 - O TRÁFICO DE PESSOAS COMO UMA PREOCUPAÇÃO
}

\author{
Ninguém será mantido em escravidão ou servidão. A escravidão e o tráfico \\ de escravos serão proibidos em todas as suas formas ${ }^{15}$
}

\section{1 - Tráfico de Pessoas: Conceito e Histórico}

Toda pessoa tem direito à vida, à liberdade e à segurança pessoal ${ }^{16}$

Dentre as violações aos direitos humanos, uma das que, de maneira incisiva e cruel, inibe o reconhecimento do indivíduo como sujeito de direitos, é o tráfico de seres humanos. A perda de liberdades é apontada por Amartya Sen (2010) como impeditiva do desenvolvimento e, por conseguinte, da dignidade humana. Segundo o Protocolo Adicional à Convenção das Nações Unidas contra o Crime Organizado Transnacional relativo à Prevenção, Repressão e Punição do Tráfico de Pessoas, em especial Mulheres e Crianças, ratificado pelo governo brasileiro em março de 2004 (Decreto 5017 de 12 de março de 2004), o tráfico de pessoas seria

o recrutamento, o transporte, a transferência, o alojamento ou o acolhimento de pessoas, recorrendo à ameaça ou ao uso da força ou a outras formas de coação, ao rapto, à fraude, ao engano, ao abuso de autoridade ou de situação de vulnerabilidade ou à entrega ou aceitação de pagamentos ou benefícios para obter o consentimento de uma pessoa que tem autoridade sobre outra, para fins de exploração. A exploração incluirá, no mínimo, a exploração da prostituição de outrem ou outras formas de exploração sexual, o trabalho ou serviços forçados, escravatura ou práticas similares à escravatura, a servidão ou a remoção de órgãos. (BRASIL, 2004, Lei 5017, artigo $3^{\circ}$, a)

\footnotetext{
${ }^{15}$ Artigo IV, Declaração Universal dos Direitos Humanos.

${ }^{16}$ Artigo III, Declaração Universal dos Direitos Humanos.
} 
Poderíamos, numa rápida síntese dos 30 artigos da Declaração Universal dos Direitos Humanos, relacionar algumas das graves violações a tais direitos, perpetradas pelo tráfico de pessoas: violação do direito à vida; à liberdade; à igualdade; à segurança pessoal; violação ao direito de não ser submetido à escravatura ou à servidão; a não ser submetido à tortura; tratamentos cruéis; desumanos ou degradantes; o não reconhecimento da personalidade jurídica; o direito a não sofrer intromissões arbitrárias na vida privada, na família, no domicílio ou na correspondência; direito de livremente circular e escolher a residência no interior de um Estado; direito de abandonar o país em que se encontra, incluindo o seu e o direito de regressar ao seu país; direito à segurança social; direito de exigir a satisfação dos direitos econômicos, sociais e culturais indispensáveis; direito ao trabalho, à livre escolha do trabalho, a condições equitativas e satisfatórias de trabalho; direito ao repouso e aos lazeres; a uma limitação razoável da duração do trabalho; direito a um nível de vida suficiente para Ihe assegurar e à sua família a saúde e o bem-estar ${ }^{17}$.

A violação de todo esse rol de direitos pode ser verificada no tráfico de pessoas. Em pleno século XXI o mundo volta a discutir o tráfico de seres humanos. Tema que poderia parecer fora de pauta em razão de todos os tratados de direitos humanos que se multiplicaram após a Segunda Guerra Mundial, o tráfico de pessoas vem ganhando espaço na sociedade contemporânea. Não se trata mais do tráfico vinculado ao colonialismo (BLACKBURN, 2000), mas aquele alimentado pelo abuso do poder econômico, pela exclusão de grande parcela da população mundial de condições dignas de trabalho e de perspectiva de uma vida melhor. Explica-se: o tráfico humano, assim como na época colonial, continua sendo um bom negócio.

Desde 2004, o Brasil aderiu às discussões atuais sobre o combate e enfrentamento ao tráfico de pessoas, com a ratificação do Protocolo Adicional à Convenção das Nações Unidas Contra o Crime Organizado Transnacional Relativo à Prevenção, Repressão e Punição do Tráfico de Pessoas, em Especial Mulheres e Crianças (2000), incorporado pelo Brasil por meio do Decreto n. 5017, de 12 de março de 2004 (BRASIL, 2004).

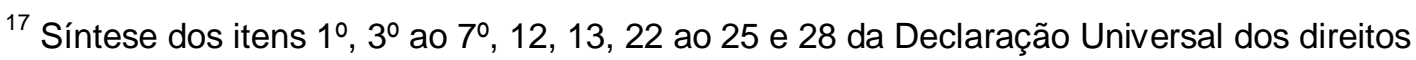
Humanos.
} 
Em 2006, o Brasil instituiu a Política Nacional de Enfrentamento ao Tráfico de Pessoas (BRASIL, 2006), em 2008 o I Plano Nacional de Enfrentamento ao Tráfico de Pessoas (BRASIL, 2008a). Em 2009, com a Portaria n. 31 da Secretaria Nacional de Justiça foi instituído apoio ao desenvolvimento do Núcleo de Enfrentamento ao Tráfico de Pessoas, atendendo a uma das metas do Programa Nacional de Segurança e Cidadania - PRONASCI (BRASIL, 2009). Em 2013, foi lançado o II Plano Nacional de Enfrentamento ao Tráfico de Pessoas (BRASIL, 2013).

A elaboração do protocolo em âmbito global e a sua ratificação, em nível nacional, bem como a implementação da Política e dos Planos Nacionais de Enfrentamento ao Tráfico de Pessoas levaram à elaboração de pesquisas institucionais e produção de relatórios sobre o tema, revelando o crescente interesse dos Estados, órgãos internacionais, organizações não governamentais, mídia e da academia sobre esse assunto.

No que concerne a trabalhos acadêmicos, ao realizar pesquisa ao Banco de teses do CAPES, com o uso dos descritores "tráfico de pessoas", "tráfico humano", "tráfico de seres humanos", "tráfico de mulheres", "tráfico internacional de mulheres" e "tráfico de crianças", foram localizadas quatro teses e 39 dissertações. Destes trabalhos, 13 foram defendidos no ano de 2012; 24 se tratavam de dissertações de mestrado em Direito ou Ciências Jurídicas, 01 (uma) tese em Direito. Os trabalhos em questão foram cadastrados entre os anos de 2004 e $2013^{18}$.

Observamos também o crescente número de publicações em formato de livro nos últimos anos sobre o tema: Marzagão Jr (2010); Nocchi, Velloso e Fava (2011); Torres (2012); Gueraldi e Dias (2012); Leal; Teresi e Duarte (2013); Piscitelli (2013).

O tema está presente também no imaginário social, o que pode ser verificado pelo crescente número de filmes produzidos sobre o tema ou que aborda de alguma forma o assunto, que poderíamos citar como exemplo: Central do Brasil (1998); Coisas Belas e Sujas (2002); Trafico Humano (2005); Anjos do

\footnotetext{
${ }^{18}$ Consulta feita em 07/11/2013, no site http://www.capes.gov.br/servicos/banco-de-teses.
} 
Sol (2006); Trade - Desaparecidos (2007); Cinderelas, Lobos e um Príncipe Encantado (2009); Biutiful (2010). Tratadas por abordagens distintas, esta temática foi gradualmente se avolumando.

A novela Salve Jorge (2012) foi lançada no horário nobre da Rede Globo de televisão abordando a temática do tráfico de pessoas. Sem sombra de dúvidas, a inserção do tema no horário nobre foi um fator importante na divulgação do tráfico de pessoas, levando as pessoas que, de uma maneira geral não teriam acesso a informações técnicas sobre o tema, a se informarem e se instigarem com o assunto, buscando maiores informações e ficando mais atentas a situações até então passadas despercebidas.

Em breve retrospectiva histórica das ações envolvendo o combate ao trabalho escravo e ao tráfico de pessoas, é possível observar que desde o século XIX, essas podem ser vinculadas a interesses outros que não a dignidade da pessoa humana. Interesses do capitalismo em ascensão, políticas higienistas, políticas migratórias e combate ao crime organizado são algumas das intenções por trás de ações e políticas contra o tráfico de seres humanos.

Em um primeiro momento, em meados do século XIX, a luta contra o tráfico negreiro e por consequência contra a escravidão pode ser entendida como pano de fundo para interesses do capitalismo industrial em ascensão, situação em que o trabalho escravo deixa de ser interessante por manter o escravo-coisa fora do âmbito das relações de consumo (BLACKBURN, 2000).

Em um segundo momento, no final do século XIX e início do século XX, o combate ao tráfico mudou de foco. Naquele momento, as atenções se viraram para o chamado tráfico de escravas brancas (CASTILHO, 2007) e as ações podem ser relacionadas às políticas higienistas (IRWIM, 2005; PEREIRA, 2005; FERREIRA, 2009; AUSSERER, 2007). Segundo Irwim (2005), várias reportagens sensacionalistas sobre o tema foram divulgadas em 1885 na Inglaterra, criando um pânico moral na população. Tudo isso surge logo após o Ato de Doenças Contagiosas, em que as prostitutas inglesas foram cadastradas visando a um combate médico. 
No Brasil, a burguesia europeizada e a instauração de um modelo moral de família, as prostitutas representavam os degredados em busca de oportunidade, atacavam a moral, disseminavam doenças para dentro dos lares. As campanhas criaram preconceito contra a prostituição e contra certo grupo de estrangeiros vinculados a essa prática. A prostituição deveria ser erradicada como instrumento de controle social.

Em um terceiro momento, essa postura higienista se manteve nos primeiros tratados e convenções sobre o combate ao tráfico de pessoas no início do século XX e mesmo no movimento atual (GRUPO DA VIDA, 2005), por meio de "empresários morais", que criam um pânico moral a fim de transformar em leis o desconforto provocado por prostitutas e migrantes irregulares, por exemplo. Somadas a essa questão, podemos encontrar duas outras motivações ao combate ao tráfico, traduzidas em políticas: controle de fronteiras, o que se verifica em leis restritivas à imigração e o combate ao crime organizado transnacional (AUSSERER, 2007). Nesse enfoque, o combate ao tráfico de pessoas teria um caráter de prevenção de crime e de preocupações pelas violações das leis de imigração.

No momento atual, não se pode desprezar que o discurso que move as ações contra o tráfico de pessoas é a proteção da dignidade humana. O respeito à dignidade deve ser entendido em todas as suas dimensões, seja protegendo os indivíduos da escravidão, da sujeição mediante violência ou fraude, da vulnerabilidade provocada pelas condições socioeconômicas aviltantes, no respeito às escolhas e à liberdade, incluindo a liberdade sexual. Mas os demais propósitos não podem ser desprezados sob pena de estarmos fazendo uma leitura estreita, imatura e romanceada do fenômeno.

O viés da moralidade pública ainda perpassa o olhar sobre a vítima, o que pode ser verificado em análise realizada por Castilho (2008), em 23 decisões judiciais proferidas em casos de tráfico de mulheres. O olhar dos juízes e a maneira como compreendem réus e vítimas ficam evidenciados nas sentenças, que acabam por reproduzir preconceitos e valores socialmente construídos. Exemplo disso é que embora o trabalho sexual não seja tipificado como crime, a 
estigmatização que as mulheres trabalhadoras do sexo sofrem, se assemelha ao tratamento dado a delinquentes (JULIANO, 2005).

Em pesquisa feita em Buenos Aires, Chejter (2010) investigou o discurso de quem paga por sexo (a quem a autora chama de prostituyentes). Neste trabalho, em que entrevista 115 prostituyentes, a autora assinala que os sujeitos que pagam por sexo, todos homens, tratam a prostituta pelo viés do mercado do sexo, da mercadoria e neste contexto colocam a mulher como coisa, como objeto de desejo, conjugando práticas do poder econômico, do poder de gênero e sexual. Para a autora, o sexismo permite aos homens assegurarem-se do acesso legítimo ao corpo da mulher. "Prostituir é apresentado como um direito dos homens" (CHEJTER, 2010, p. 10). Os homens, neste mercado, são os consumidores, e como diz o ditado: "O cliente tem sempre razão".

\section{2 - O Tráfico de Pessoas e o Poder econômico}

Toda pessoa que trabalhe tem direito a uma remuneração justa e satisfatória, que lhe assegure, assim como à sua família, uma existência compatível com a dignidade humana, e a que se acrescentarão, se necessário, outros meios de proteção social. ${ }^{19}$

Um dos fatores impeditivos da promoção da dignidade humana seriam as forças de mercado cada vez mais desregulamentadas, isentas de um controle político eficaz, guiadas pelas pressões da competitividade. Grandes corporações internacionais tem faturamento maior que o Produto Interno Bruto de diversos países. Apesar da "opulência global", nunca antes alcançada como nos níveis atuais, o que podemos ver é um mundo que nega liberdades elementares à maioria das pessoas (SEN, 2010). Para Bauman, esta exclusão é característica

\footnotetext{
${ }^{19}$ Artigo XXIII, 3, Declaração Universal dos Direitos Humanos
} 
da liquidez da vida moderna, que gera coisas e pessoas descartáveis, transformadas em refugos sociais (BAUMAN, 2007).

O Mercado de trabalho é profundamente afetado pelos interesses dominados pelo poder econômico, o que pode ser observado pela precarização das relações de trabalho, a informalização do emprego, a racionalização, corte de empregos, redução de funcionários, flexibilização do trabalho, a diminuição de direitos. Para Acharya e Stevanato (2005), em texto que analisa o Tráfico de Mulheres para fins de exploração sexual no México, a lucratividade do tráfico de pessoas talvez seja uma das principais razões que impede que se tomem medidas mais efetivas para erradicar essa prática.

Para Bauman (2005), o mundo líquido moderno não produz apenas desempregados, mas "redundantes". O desemprego remete a uma temporalidade e tem como antônimo o emprego. A redundância, por outro lado, sugere permanência e aponta para a regularidade da condição. Não possui antônimo. Ser redundante é ser extranumerário, desnecessário, sem uso, descartável. Ser declarado redundante significa ter sido dispensado pelo fato de ser dispensável. Lixo, refugo. O destino dos desempregados é serem chamados pelo mercado de trabalho. O destino do refugo é o lixo.

Para Amartya Sen (2010) "entre os desafios cruciais do desenvolvimento em muitos países atualmente inclui-se a necessidade de libertar os trabalhadores de um cativeiro explícito ou implícito que nega o acesso ao mercado de trabalho aberto" (p. 21). Para o autor, a falta de liberdade para participar do mercado de trabalho é uma das diversas formas de manter a "sujeição e o cativeiro da mão de obra". A luta contra a privação de liberdade, verificada em qualquer tipo de coação que força uma pessoa a trabalhar e viver em determinada propriedade ou para determinada corporação, é fundamental nos países do Terceiro Mundo ${ }^{20}$.

O trabalho forçado pode ser apontado como o extremo da precarização do trabalho, ou da violação dos direitos humanos no âmbito do trabalho. Segundo a Aliança Global contra trabalho forçado em Relatório Global do Seguimento da

\footnotetext{
${ }^{20}$ SEN, op. cit., p. 21. Na tradução, esta coação para o trabalho foi denominada de trabalho adscrítico (Bound labor no original).
} 
Declaração da OIT sobre Princípios e Direitos Fundamentais no Trabalho (OIT, 2005), o trabalho forçado está presente, de alguma forma, em todos os continentes, em quase todos os países e em toda espécie de economia, nas suas diversas formas, entre elas o trabalho servil, a servidão por dívida, o trabalho forçado imposto pelos Estados, o trabalho forçado de migrantes e o tráfico de seres humanos.

Dados de 2005 (OIT, 2005), apontam que 20\% do trabalho forçado no mundo se dá sob a forma de tráfico de pessoas ${ }^{21}$. Esta informação deve ser analisada a partir de duas observações: primeiro, que estes dados sofrem grande variação geográfica. Nas regiões que compreendem os países da América Latina e Caribe, África Subsaariana e Ásia e Pacífico, menos de $20 \%$ do total de pessoas submetidas a trabalho forçado são vítimas de tráfico de pessoas. Já em países industrializados, Oriente Médio e Norte da África e Países em Transição, mais de $75 \%$ das vítimas de trabalho forçado o são pela via do tráfico de pessoas $^{22}$; em segundo lugar, é importante ressaltar que os dados são medidos nos países de destino das vítimas, onde estas são forçadas a trabalhar, e não no país de origem.

Deste modo, as estimativas comparativamente baixas para a África, América e países em transição, se comparadas com os dados dos países industrializados, em transição e Oriente Médio, não devem esconder o fato de que muitas pessoas daquelas regiões são traficadas e levadas para estas, inclusive para países industrializados. Os dados não nos permitem, assim, revelar a nacionalidade das vítimas de trabalhos forçados que foram traficadas.

Segundo relatório da Aliança Global Contra Tráfico de Mulheres, o tráfico de seres humanos superou o tráfico de armamentos e o tráfico de drogas, tornando-se a atividade criminosa mais lucrativa do mundo, "já que as pessoas podem ser vendidas e revendidas" (ALIANÇA GLOBAL, 2006, p. 06). Os dados da Organização Internacional do Trabalho (OIT, 2005), revelam que

\footnotetext{
${ }^{21}$ Num total de 12,3 milhões de vítimas de trabalho forçado no mundo, 2,44 milhões o são a partir do tráfico de pessoas. (OIT, 2005)

${ }^{22}$ América Latina e Caribe: 18,9\%; África Subsaariana: 19,7\%; Ásia e Pacífico: 14,3\%; Países Industrializados: 75\%; Oriente Médio: 88,4\%; Países em Transição: 95,23\%.
} 
Os lucros totais ilícitos produzidos por ano pelo tráfico de trabalhadores forçados são estimados em cerca de US\$ 32 bilhões de dólares. Metade desse lucro é gerada em países industrializados ( 15,5 bilhões de dólares) e de quase um terço na Ásia (9,7 bilhões de dólares). Isso representa globalmente uma média aproximada de 13 mil dólares anuais por trabalhador forçado ou de mil dólares por mês ( $p$. $61)$.

De acordo com o relatório "Não ao Trabalho Forçado" (OIT, 2001), o tráfico de pessoas apresenta em vários momentos características de trabalho forçado. As principais vítimas são mulheres, mas atinge também homens e crianças, tanto em países ricos como em países pobres.

Os pontos de origem podem ser os países mais pobres e, em geral, as zonas rurais mais desfavorecidas desses países. As principais destinações costumam ser os centros urbanos dos países mais ricos - Amsterdã, Bruxelas, Londres, Nova lorque, Roma, Sidnei, Tóquio - e as capitais de países em desenvolvimento e em transição. Mas a movimentação de pessoas traficadas é muito complexa e variada. Países tão diferentes como Albânia, Hungria, Nigéria e Tailândia podem funcionar como pontos de origem, de destinação e de trânsito ao mesmo tempo (p. 65).

\section{3 - Quem são as Vítimas do Tráfico de Pessoas}

\section{Toda pessoa tem o direito de ser, em todos os lugares, reconhecida como pessoa perante a $1 \mathrm{e}^{23}$}

Pela leitura do artigo $3^{\circ}$ do Protocolo ${ }^{24}$, verifica-se que a tráfico de pessoas inclui não apenas a exploração da prostituição de outrem ou outras formas de

\footnotetext{
${ }^{23}$ Artigo VI, Declaração Universal dos Direitos Humanos.

${ }^{24}$ Art. 3ำ, a: A expressão tráfico de pessoas significa o recrutamento, o transporte, a transferência, o alojamento ou o acolhimento de pessoas, recorrendo à ameaça ou ao uso da força ou a outras formas de coação, ao rapto, à fraude, ao engano, ao abuso de autoridade ou de situação de vulnerabilidade ou à entrega ou aceitação de pagamentos ou benefícios para obter o consentimento de uma pessoa que tem autoridade sobre outra, para fins de exploração. A exploração incluirá, no mínimo, a exploração da prostituição de outrem ou outras formas de
} 
exploração sexual, mas também o trabalho ou serviços forçados, a escravatura ou práticas similares à escravatura, a servidão ou a extração de órgãos. Outro dado importante é que apesar do Preâmbulo e do artigo $2^{\circ}$ do Protocolo fazerem menção especial à proteção de mulheres e crianças, está aberto, pela leitura do artigo $3^{\circ}$, a todos os indivíduos.

Podemos identificar diferentes grupos vulneráveis especificados em cada uma das formas de tráfico humano definidos em referido artigo. O tráfico humano previsto para fins de remoção de órgãos é uma prática favorecida pela tecnologia, tanto na remoção quanto no transporte de órgãos, que envolve profissionais qualificados e instituições de saúde bem equipadas. Esta modalidade atinge sobretudo jovens em bom estado de saúde.

Segundo Naím (2006), "não há leis internacionais que definam e regulem esse comércio, as leis nacionais variam de países que proibiram toda e qualquer venda de órgãos aos que permitem a corretores de órgãos exercerem livremente suas atividades" (p. 151).

No Brasil a Lei 9434/97, que trata da remoção de órgãos, tecidos e partes do corpo humano para fins de transplante e tratamento, dispõe em seu artigo 1ํㅜ que a disposição de tecidos, órgãos e partes do corpo humano (salvo sangue, esperma e óvulos) em vida ou post mortem tem caráter gratuito. A doação em vida está regida pelo artigo $9^{\circ}$ e parágrafos, restringindo-se ao "cônjuge ou parentes consanguíneos até o quarto grau, inclusive" (caput) e, como disposto no $\S 3^{\circ}$ do referido artigo,

Só é permitida a doação referida neste artigo quando se tratar de órgãos duplos, de partes de órgãos, tecidos ou partes do corpo cuja retirada não impeça o organismo do doador de continuar vivendo sem risco para a sua integridade e não represente grave comprometimento de suas aptidões vitais e saúde mental e não cause mutilação ou deformação inaceitável, e corresponda a uma necessidade terapêutica comprovadamente indispensável à pessoa receptora.

exploração sexual, o trabalho ou serviços forçados, escravatura ou práticas similares à escravatura, a servidão ou a remoção de órgãos. (BRASIL, 2004, Lei 5017, artigo $3^{\circ}$, a). 
Para fins de exploração sexual a vulnerabilidade atinge principalmente mulheres e meninas, como aponta pesquisa concluída em 2009 pelo Escritório das Nações Unidas sobre Drogas e Crime (UNODC), que indicou que 66\% das vítimas eram mulheres, $13 \%$ eram meninas, $12 \%$ eram homens e $9 \%$ meninos. 0 maior percentual de mulheres entre as vítimas do tráfico para fins de exploração sexual pode ser explicado pela grande discriminação de gênero presente ainda nas sociedades contemporâneas. A inserção da mulher no mercado de trabalho ainda é mais custosa, a renda da mulher é mais baixa que dos homens, a mulher é vítima de violência que acontece sobretudo no ambiente doméstico, e os agressores em sua maioria são parceiros ou ex-parceiros (IPEA, 2011).

Em dados recentes do Instituto de Pesquisa Econômica Aplicada - IPEA, divulgados em 25/09/2013, a Lei Maria da Penha - Lei 11.340/06, não promoveu um decréscimo na mortalidade de mulheres por meio de agressões. O período de 2001 a 2006 teve uma taxa de mortalidade de 5,28 por 100 mil mulheres, enquanto no período de 2006 (ano da publicação da lei) até 2011, a taxa foi de 5,2. Isto é, não houve queda em razão da publicação da lei.

Estes dados são alarmantes sobretudo quando se constata que a cada hora e meia no Brasil morre uma mulher, de morte violenta - 50\% dos feminicídios envolveram o uso de armas de fogo e 34\%, de instrumento perfurante, cortante ou contundente. Enforcamento ou sufocação foi registrado em $6 \%$ dos óbitos. Maus tratos - incluindo agressão por meio de força corporal, força física, violência sexual, negligência, abandono e outras síndromes de maus tratos (abuso sexual, crueldade mental e tortura) - foram registrados em 3\% dos óbitos -, $54 \%$ dessas mulheres têm entre 20 e 39 anos de idade, 61\% são negras, com baixa escolaridade (IPEA - 2013).

Damásio de Jesus (2003) entende que há um padrão similar no que concerne à exploração da mulher, em vários países: mulheres jovens que procuram trabalhos legítimos são ludibriadas por agentes especializados em tráfico de pessoas e quando chegam ao destino têm seus documentos confiscados, mobilidade restrita, são vítimas de represália, estupros, agressões e drogadição. A vulnerabilidade da mulher se origina da facilidade dos fluxos migratórios, da ausência de direitos, baixa aplicação das regras internacionais de 
direitos humanos, a discriminação de gênero, a violência contra a mulher, a pobreza, a desigualdade de oportunidades e renda; a instabilidade econômica, as guerras, os desastres naturais e a instabilidade política. Tudo isso levando ao fenômeno denominado "feminilização da pobreza" (JESUS, 2003, p. 20).

Os adultos são aliciados com a promessa de melhoria na qualidade de vida, oportunidade de trabalho. Algumas pessoas estão conscientes de que exercerão a prostituição, mas não imaginavam em que condições e nem que seriam cobradas de maneira extorsiva pelos gastos de transporte, alimentação, moradia, que teriam seu passaporte retido sendo obrigadas a viver na clandestinidade (MINISTÉRIO DA JUSTIÇA, 2010).

As crianças, na maioria das vezes, são levadas para o tráfico através de sequestro. As mais vulneráveis são crianças de rua, o que ressalta a vulnerabilidade vinculada a questões socioeconômicas. Muitas das meninas são vendidas e colocadas à disposição do tráfico por seus próprios pais, ou meramente pelo dinheiro, ou porque os pais acreditam que desta forma suas filhas estarão livres da pobreza (JESUS, 2003). Quando o tráfico envolve exploração sexual de crianças, pesquisa realizada nos Estados Unidos pelo Congressional Research Service (FINKLEA; FERNANDES-ALCÂNTARA; SISKIN, 2011), revela dados assustadores. Segundo a pesquisa, apesar do Congresso Americano através do Ato de Proteção às Vítimas de Tráfico de 2000, ter legislado no sentido de que as crianças envolvidas em crimes de comércio sexual deverem ser tratadas como vítimas, o que os pesquisadores têm observado é, em nível estadual e local, as crianças têm sido rotuladas como prostitutas ou como delinquentes juvenis, sendo muitas vezes tratadas como criminosas e não como vítimas.

A Lei 12.015 de 2009 (BRASIL, 2009), que alterou entre outros os artigos 231 e 231A do Código Penal Brasileiro, acompanhando a tendência trazida pelo Protocolo de Palermo, amplia a definição de tráfico. Pela redação original do Código Penal, o Capítulo V tratava do Lenocídio e do Tráfico de Mulheres. Em 2005, com a redação trazida pela Lei 11.106, o Capítulo V passou a dispor sobre Lenocídio e do Tráfico de Pessoas, já melhor adequado ao Protocolo de Palermo. Em 2009, com a Lei 12.015, a alteração da redação do Capítulo $V$ passou a 
determinar que o mesmo trata do Lenocídio e do Tráfico de Pessoa para fim de Prostituição ou outra forma de Exploração Sexual.

As alterações trazidas possibilitaram incluir uma parcela de cidadãos que de maneira crescente tem sido vítima do tráfico de pessoas, os travestis. A exploração sexual também tem atingido travestis e transexuais, estes, na maioria, marginalizados e vítimas de preconceitos, exclusão e abuso, que favorecem a exploração. A realidade dos travestis e transexuais tem sido marcada por uma série de exclusões que começam nas famílias, passam pela escola e desaguam no mercado de trabalho. Para a maioria, a prostituição é uma saída, em todos os sentidos.

(...) interpretar a escolha pela prostituição como falta de opção seria por demais reducionista. O mercado do sexo avulta para muitas travestis como possibilidade concreta, não só de obter renda e sustento, mas de socialização, e expressão de uma sensualidade feminina coerente com suas identidades e desejos. A rua lhes orienta condutas, práticas e aprofunda transformações, tanto físicas quanto psicológicas. Fora do ambiente doméstico, elas são aceitas, estabelecem referências positivas, (...) aprendem a se vestir, a ingerir hormônios que lhes arredondam os corpos, a desenvolver cuidados estéticos tidos como típicos de mulher (AGNOLETI, 2008, p. 2).

São atraídas pelos grandes centros, sobretudo a Europa, como um lugar onde poderão tornar real a alteração no corpo que Ihes confira características femininas, bem como terão acesso a artigos de luxo e grifes de maneira mais acessível, além de afastarem-se de seu lugar de origem, que normalmente lhes é hostil, buscando no anonimato dos grandes centros urbanos um local menos opressor, menos assustador e por vezes, mais acolhedor (AGNOLETI, 2008). Além da Europa, os grandes centros no Brasil, principalmente Rio de Janeiro e São Paulo, tem atraído os travestis como uma possibilidade de fuga da opressão e busca de uma vida mais digna.

Ocorre, que nesta ânsia de uma vida melhor muitos travestis acabam sendo aliciados por redes de tráfico de pessoas, contraindo dívidas imensas relativas a gastos com passagens, alimentação, vestuário e com isso acabam tornando-se, como as mulheres, escaravas sexuais, a mercê de rufiões e 
cafetinas (VASCONCELOS, 2009) como verificado nas operações tarantela ${ }^{25}$, que desbaratou uma rede de tráfico de travestis do Estado de Goiás para a Itália, e a operação Caraxué ${ }^{26}$, que também desbaratou uma rede de tráfico de travestis, originados de Minas Gerais, São Paulo e Santa Catarina, com destino a Milão na Itália Madri na Espanha.

É importante ressaltar que o Código Penal dispõe sobre o Tráfico Internacional de Pessoa para fim de Prostituição ou outra forma de Exploração Sexual (Art. 231) e o artigo 231 A, sobre o tráfico interno para o mesmo fim. Apesar do Protocolo de Palermo ser um "Protocolo Adicional à Convenção das Nações Unidas contra o Crime Organizado Transnacional (grifo nosso) relativo à Prevenção, Repressão e Punição do Tráfico de Pessoas", não há restrição à concepção de que o tráfico de pessoas também ocorre dentro das fronteiras de um país, sobre seus nacionais.

Estas alterações mostram que além da adequação da lei brasileira ao protocolo internacional houve a ampliação do conceito de tráfico de seres humanos que não restringe mais o crime a vítimas mulheres e que também não o restringe aos fins de prostituição e exploração sexual. Em seu artigo 149, o Código Penal (alterado pela Lei Federal no 10.803/03), dispõe sobre a criminalização da exploração do trabalho que reduz o ser humano à condição análoga a de escravo, sendo este entendido como trabalhos forçados ou a jornada exaustiva, condições degradantes de trabalho, restrição de locomoção em razão de dívida contraída com o empregador ou preposto, cerceamento de transporte com o fim de reter o trabalhador no local de trabalho ou ainda vigilância ostensiva no local de trabalho ou retenção de documentos ou objetos pessoais do trabalhador, com o objetivo de retê-lo no local de trabalho.

Segundo o Relatório Final de execução do I Plano Nacional de Enfrentamento ao Tráfico de Pessoas (SNJ, 2010), o trabalho escravo é favorecido pela globalização econômica que entre outras coisas leva à

\footnotetext{
${ }^{25}$ Disponível em http://www.prgo.mpf.mp.br/criminal-e-controle-externo-da-atividadepolicial/noticias/1196-operacao-tarantela-mpfgo-oferece-denuncia-por-trafico-internacional-deseres-humanos.html, acesso em 25/1/2013

${ }^{26}$ Disponível em http://www.ambito-juridico.com.br/site/index.php?n link=revista artigos leitura\&artigo id $=1397$, acesso em 25/11/2013..
} 
precarização das relações de trabalho. A abundância de mão-de-obra desocupada acaba fomentando a propagação do trabalho escravo, situação complicada no âmbito internacional pelos complexos fluxos migratórios do mundo. Na análise de Naím (2006)

Os impulsos humanos que compelem à imigração são antigos e difíceis de serem contidos. Os imigrantes podem ser levados por oportunidade, esperança, desespero ou simplesmente necessidade de sobrevivência. Os traficantes aproveitam-se desses impulsos e, graças à sua habilidade de driblar os obstáculos interpostos pelos governos, podem transformá-los em lucros (2006, p. 86).

Em cartilha publicada em outubro de 2013, em um convênio entre a Secretaria de Justiça e Defesa da Cidadania do Estado de São Paulo e a Ordem dos Advogados do Brasil - SP, os dados apontam que no Estado de São Paulo há uma maior incidência de homens e maiores de 18 anos entre as vítimas do tráfico de pessoas. A grande maioria das vítimas são Bolivianos (66\%), que migram para São Paulo com vistas a trabalhar principalmente nas indústrias de confecções. ${ }^{27}$ Em 25/09/2013 foi noticiado no site Repórter Brasil ${ }^{28}$ e amplamente divulgado na grande mídia ${ }^{29}$, a ocorrência de violação aos direitos de 111 trabalhadores utilizados nas obras de ampliação do Aeroporto de Cumbica, em Guarulhos, supostamente mantidos em condições análogas à de escravos pela empresa OAS. Neste caso os trabalhadores vinham, sobretudo, do nordeste do Brasil.

${ }^{27}$ Cartilha Tráfico de Pessoas para fins de Trabalho Escravo e Tráfico de Pessoas para fins de Exploração Sexual. Dados preliminares e parciais disponível em http://www.conjur.com.br/2013out-24/homem-maior-18-anos-principal-vitima-trafico-pessoas-sp, acesso em 12/11/2013. ${ }^{28}$ Disponível em http://reporterbrasil.org.br/2013/09/fiscais-flagram-trabalho-escravo-em-obra-daoas-para-ampliacao-do-aeroporto-internacional-de-guarulhos-sp/ - acesso em 05/11/2013.

${ }^{29}$ Disponível em http://g1.globo.com/sao-paulo/noticia/2013/09/fiscais-flagram-111-operarios-decumbica-em-situacao-de-escravidao.html (Rede Globo de Televisão - Portal Globo.com), Disponível em http://noticias.r7.com/economia/noticias/oas-e-gru-airport-sao-acusadas-detrabalho-escravo-20130926.html, (Rede Record de Televisão - Portal R7), acesso em 05/11/2013 Disponível em http://www1.folha.uol.com.br/mercado/2013/09/1347459-oas-matinha-trabalhodegradante-em-obras-do-terminal-de-guarulhos-diz-mte.shtml (Folha de São Paulo), acesso em 05/11/2013. 


\section{4 - Polêmicas sobre o Consentimento e sobre a distinção entre Tráfico de Pessoas e Contrabando de Migrantes}

\section{Toda pessoa tem o direito de deixar qualquer país, inclusive o próprio, e a este regressar ${ }^{30}$}

É necessário que seja feita uma reflexão acerca de alguns pontos polêmicos que envolvem o enfrentamento ao tráfico de pessoas. O primeiro ponto que iremos abordar é o que se refere ao consentimento da vítima.

A alínea "b" do artigo $3^{\circ}$ do Protocolo de Palermo determina que "O consentimento dado pela vítima de tráfico de pessoas tendo em vista qualquer tipo de exploração descrito na alínea 'a' do presente Artigo será considerado irrelevante se tiver sido utilizado qualquer um dos meios referidos na alínea 'a'”31 (BRASIL, 2004, Lei 5017, artigo 3ª, b). Referidos meios são ameaça, uso da força, outras formas de coação, rapto, fraude, engano, abuso de autoridade ou de situação de vulnerabilidade, entrega ou aceitação de pagamentos ou benefícios. (artigo 3oㅡ, alínea a, Lei 5017).

Em qualquer das formas em que o tráfico humano se manifesta a fragilidade da condição em que a vítima se encontra, em razão da falta de perspectiva de uma vida melhor, pode levá-la a submeter-se a condições de negativa de direitos, se é que se poderia considerar haver autonomia num consentimento viciado por uma situação que beira à coação (provocada pela situação socioeconômica vivida). A situação se complica ainda mais quando verificamos que a grande maioria das vítimas de fato não tinha nenhuma compreensão da situação em que se encontrava e não consegue enxergar possibilidade de livrar-se da situação de exploração.

\footnotetext{
${ }^{30}$ Artigo XIII, 2, Declaração Universal dos Direitos Humanos.

31 "Em nota interpretativa $n^{\circ}$ 68, o travaux preparatoires indica que este subparágrafo não deve ser colocado como uma imposição de restrição do direito do acusado em ter uma defesa justa e presunção de inocência. Eles deveriam indicar que deveria ser interpretada como uma imposição do ônus da prova à vítima. Em qualquer processo criminal, o ônus da prova compete ao Estado ou promotor público, de acordo com a lei doméstica." (GAATW, 2006, p. 29)
} 
Naím, em seu estudo sobre crimes transnacionais, faz leitura detalhada do tráfico humano. Ao analisar este tema no que se refere ao tráfico de órgãos, conclui que a captação dos órgãos têm-se tornado fácil diante da oferta dos órgãos partindo dos próprios vendedores/doadores. Um rim pode valer $10 \mathrm{mil}$ dólares e existem vendedores que os anunciam abertamente "poupando traficantes da necessidade de recrutá-los" (NAíM, 2006, p. 152). O risco de vida é grande e as condições a que são submetidas os "doadores", é precária. A oferta de órgãos é ainda maior quando se analisa grupos de "imigrantes miseráveis, ilegais e assustados, famintos, sem qualquer proteção legal" (op. cit, p. 153.). Em muitos casos, no entanto, não há aquiescência do "doador", que muitas vezes ao ser submetido a uma "pequena cirurgia", acaba por ter um órgão extirpado.

O cenário do tráfico para fins de exploração sexual e para trabalho escravo ou análogo à escravidão não é menos desolador. Muitas mulheres e crianças são raptadas sendo submetidas à exploração sexual. As mais jovens são muitas vezes iludidas com promessas de amor e casamento. É o caso do relato de Marcela, no livro Del Cielo al Infierno en un día (OROZCO; HERNÁNDEZ, 2011). Outras são aliciadas com a promessa de melhoria na qualidade de vida e são surpreendidas por uma dívida que nunca conseguem pagar e expostas a condições de existência degradantes.

Outra polêmica que merece a nossa atenção se refere à distinção entre tráfico de pessoas e tráfico ou contrabando de migrantes. O Decreto 5.017 de 12 de março de 2004 (BRASIL, 2004), que ratifica o Protocolo adicional à Convenção das Nações Unidas contra o Crime Organizado Transnacional, relativo ao combate ao tráfico de migrantes, define tráfico de migrantes em seu artigo $3^{\text {o }}$ como sendo:

a promoção, com o objetivo de obter direta ou indiretamente um beneficio financeiro ou outro benefício material, da entrada ilegal de uma pessoa num estado parte do qual essa pessoa não seja nacional ou residente permanente.

$\mathrm{Na}$ análise de dois documentos oficiais, podemos observamos a importância de se distinguir o tráfico de pessoas do tráfico de migrantes, este sim, necessariamente internacional. No Manual de primeros auxilios para los 
funcionarios de los servicios de aplicación de la ley encargados de la respuesta inicial en los casos de trata de personas (NACIONES UNIDAS, s/d) e no relatório do Tráfico internacional de pessoas e tráfico de migrantes entre deportados(as) e não admitidos(as)que regressam ao Brasil via o aeroporto internacional de São Paulo (OLIVEIRA; CAMPOS, 2007), são declinadas três diferenças básicas: com relação à exploração, com relação ao consentimento e com relação ao caráter transnacional.

Com relação à exploração o tráfico de pessoas necessariamente pressupõe exploração, enquanto o tráfico de migrantes pressupõe a remuneração do aliciador pelos serviços, previamente pagos; quanto ao consentimento o tráfico de migrantes é feito com o consentimento do envolvido e no tráfico de pessoas ou o indivíduo nunca deu o consentimento ou o deu sem saber a dimensão das limitações à sua liberdade posteriormente impostas; com relação ao caráter transnacional, o tráfico de migrantes é sempre transnacional e o tráfico de pessoas pode ou não ser.

Nos documentos sobre o tráfico de pessoas, produzidos pelas Nações Unidas observa-se que, embora o tráfico de pessoas e o tráfico de migrantes constituam delitos diferentes, nos casos reais pode haver elementos de ambos ou a mutação de um delito para outro (NACIONES UNIDAS, 2007). Distinção também feita por Naím (2006), que trata o tráfico de migrantes como "contrabando humano" (p. 85), mas reconhece também que a distinção entre contrabando e tráfico humano não é tão clara.

É o que acontece quando, por exemplo, mulheres que são traficadas para outro país, com a intenção de migração ilegal, mas, não tendo como pagar pelo transporte, são obrigadas a prostituir-se. Neste caso, o tráfico de migrantes é transformado em tráfico de seres humanos, uma vez que o consentimento cessou. Mas, apesar das distinções, em ambos os casos o caráter econômico mostra-se presente e em muitos casos também a fronteira entre consentimento e coação é bastante tênue. Segundo Naím, "muitos imigrantes voluntariamente contrabandeados contraem dívidas exorbitantes e arbitrárias que os levam a aceitar trabalhos aviltantes e condições de trabalho indignas, convenientemente 'arranjados' pelos contrabandistas"' (2006, p. 85). 
O perfil do trabalhador migrante que pode ser aliciado pelo tráfico de pessoas também é um dado controverso, bem como características socioeconômicas e jurídicas tanto do país de origem quanto do país de destino.

\section{5 - Vulnerabilidades de Origem e de Destino}

Toda pessoa, como membro da sociedade, tem direito à segurança social e à realização, pelo esforço nacional, pela cooperação internacional e de acordo com a organização e recursos de cada Estado, dos direitos econômicos, sociais e culturais indispensáveis à sua dignidade e ao livre desenvolvimento da sua personalidade ${ }^{32}$

Dois milhões e meio de pessoas são vítimas de tráfico de pessoas no mundo. Os dados ainda são insuficientes para uma leitura geral do tráfico de seres humanos, mas de uma maneira geral o tráfico se dá a partir de regiões mais pobres para as mais ricas. Dizemos região, em razão do tráfico se dar tanto entre países quanto dentro de um mesmo país. Na Europa, estima-se que existam 140 mil vítimas de tráfico, gerando uma renda bruta anual de 3 bilhões de dólares para seus exploradores. Com um período médio de exploração de dois anos, isso sugeriria mais de 70 mil entradas de novas vítimas a cada ano (UNODC, 2010) ${ }^{33}$.

Segundo a OIT (2005), o tráfico se dá a partir do declínio das oportunidades de emprego e aumento da aspiração por consumo, incentivam a migração da zona rural para o espaço urbano e de países e regiões pobres para ricas. Migrantes irregulares aceitam várias formas de exploração em razão da ilegalidade de sua situação e por terem receio de serem deportados. As barreiras

\footnotetext{
${ }^{32}$ Artigo 22, Declaração Universal dos Direitos Humanos

${ }^{33}$ Texto original "estimates that there are 140,000 trafficking victims in Europe, generating a gross annual income of US $\$ 3$ billion for their exploiters. With an average period of exploitation of two years, this would suggest over 70,000 new entries every year" (UNODC, 2010).
} 
à migração legal acabam por favorecer a imigração clandestina, sendo esses trabalhadores, na grande maioria das vezes, duplamente explorados:

Os países mais ricos levantam cada vez mais barreiras à migração legal e regular, fazendo com que, elementos criminosos aproveitam da oportunidade para ter mais lucros. Alguns intermediários cobram pesadas somas de candidatos a migração para viabilizar ilegalmente a travessia de fronteiras, e outros usam práticas coercitivas e falazes para ganhar ainda mais no local de destino. Em suma, o tráfico de pessoas é uma reação oportunista a tensões entre a necessidade de migrar e as restrições de natureza política para permitir o mesmo (OIT, 2005, p. 51).

Para melhor compreender a oferta e a demanda e o perfil dos trabalhadores migrantes mais afetados pela exploração de trabalho forçado, a OIT (2005) realizou uma pesquisa em alguns países no período de dois anos. Os resultados apontaram que o tráfico de pessoas nem sempre resulta de coerção física direta. Muitas vezes o migrante entra no país de destino voluntariamente, inclusive com a ajuda de familiares e amigos. Estando irregulares, ficam mais suscetíveis à exploração, uma vez que são ameaçados de serem denunciados e deportados.

Desta forma, irregularidade no país de destino é uma justificativa maior à exploração do que a coerção no país de origem; as vítimas comumente relutam em denunciar, ou por medo, ou por desinformação, ou por não haver uma rede de proteção que garanta sua segurança e de sua família; Indústria do sexo, agricultura e construção são as mais inclinadas à prática de tráfico de pessoas; a ilegalidade favorece a vinculação dos migrantes com intermediários inescrupulosos, que exploram a falta de informação das vítimas sobre as reais ofertas de emprego no exterior.

O que parece pacífico nas pesquisas é que 0 tráfico de pessoas é impulsionado por questões socioeconômicas, seja motivado pela miséria ou por padrões de consumo não alcançáveis a partir das possibilidades de trabalho oferecidas no país ou região de origem. As vítimas, de uma maneira geral, buscam trabalho e melhores condições de vida em outros países. A maior parte 
do trabalho forçado traficado afeta pessoas que trabalham à margem da economia formal, com emprego irregular ou situação de migrado.

O primeiro Relatório Global sobre trabalho forçado (OIT, 2001) referiu-se ao tráfico de pessoas como "o outro lado da globalização". Essa perspectiva é de fundamental importância, quando se atenta para os perigos que representam forças descontroladas do mercado para grupos mais vulneráveis, como as mulheres migrantes. $O$ tráfico de pessoas deve ser analisado entre fronteiras para os países mais ricos. Há aspectos de globalização que acentuam o risco de condições de trabalho forçado nos países mais pobres que se vêm forçados a produzir bens mais baratos para os mercados globais.

A pressão por lucro leva à precarização das relações de emprego. A globalização favorece isso, uma vez que a competitividade é muito grande e o lucro depende da redução dos custos de produção. Na mesma lógica da economia monopolista do Brasil Colônia (FURTADO, 2003), na economia globalizada, quanto menos se gasta com a manutenção da produção, mais lucro se tem, ficando todo o excedente nas mãos dos que antes eram considerados proprietários, podendo hoje ser entendidos como aliciadores e exploradores no que se refere ao tráfico de pessoas. Assim como no Brasil escravista, o tráfico de pessoas (a "modern-day slavery", segundo Giammarinaro, 2011) favorece o lucro do traficante e do empresário que explora o trabalho de forma irregular.

Não é possível desenvolver uma análise sobre tráfico de pessoas sem mencionar o binômio inclusão-exclusão. As pesquisas sobre o tema (LEAL; LEAL, 2002; COLARES, 2004; OLIVEIRA; CAMPOS, 2007; HAZEU, et al., 2008, CASTILHO, 2008, entre outras) apontam que a maioria das vítimas são anteriormente vítimas de exclusão social, apesar do tráfico de seres humanos não se restringir apenas às pessoas sócio-economicamente desfavorecidas.

Segundo a OIT (2005), se de um modo geral a migração exige do migrante certo capital financeiro e social, pesquisas sobre tráfico de pessoas apontam que as vítimas de tráfico não têm acesso a esse capital, tornando-se presas fáceis de grupos ou indivíduos criminosos que as exploram. São mais vulneráveis, mais mal informadas e mais carentes, inclusive de redes sociais. "A pobreza, todavia, só 
pode ser considerada como possível causa principal juntamente com outros fatores como discriminação, corrupção e mal (sic) funcionamento de mercados de trabalho" (p. 61).

Também não é possível desenvolver uma análise sobre tráfico de pessoas sem estabelecer uma relação entre este tipo de exploração e o poder econômico, que é um elemento importante na explicação de padrões de distribuição de renda. Segundo Salomão (2006) a influência do poder econômico "se dá por meio da criação de estruturas concentradoras, que acabam sendo os determinantes do alto grau de desigualdade de renda e da pobreza aguda observadas" (p. 19).

Podemos observar que ainda há um descompasso entre o propósito de proteção da dignidade humana e as ações efetivas. Os dados apontam grande número de vítimas, mas não mostram onde essas vítimas estão. Os discursos das políticas reforçam a necessidade de proteção da vítima, seu acolhimento, mas o que se vê na prática são ações que visam ao seu retorno ao local de origem (seja a cidade ou o estado, no tráfico interno, seja o país, no tráfico internacional), sem, no entanto, ouvi-las sobre o que desejam. O retorno compulsório da vítima ao país de origem pode esconder por trás da ajuda, a intenção de controlar a imigração.

Nesse cenário, importante uma referência a Andrade, em artigo que discute criminologia e feminismo. Em uma reflexão a partir da mudança de papel da mulher, da mulher como vítima à mulher como sujeito de construção de cidadania, faz uma análise do sistema penal como sendo ineficaz para a proteção das mulheres contra a violência, uma vez que revitimiza a mulher ressaltando a desigualdade de classes e a desigualdade de gênero. Para a autora,

$\left.1^{\circ}\right)$ Num sentido fraco, o sistema penal é ineficaz para proteger as mulheres contra a violência porque, entre outros argumentos, não previne novas violências, não escuta os distintos interesses das vítimas, não contribui para a compreensão da própria violência sexual e a gestão do conflito, e muito menos, para a transformação das relações de gênero [...]; $2^{\circ}$ num sentido forte, o sistema penal duplica a vitimação feminina porque as mulheres são submetidas a julgamento e divididas [...] estabelecendo uma grande linha divisória ente as mulheres consideradas "honestas" [...] que 
podem ser consideradas vítimas pelo sistema, e as mulheres "desonestas" [...], que o sistema abandona na medida em que não se adéquam aos padrões de moralidade sexual impostas pelo patriarcalismo à mulher. (ANDRADE, 1999, p. 113).

Numa análise dos relatórios oficiais e dos trabalhos acadêmicos, podemos verificar que não há um consenso sobre os dados apresentados. De uma maneira geral os relatórios supervalorizam o número de vítimas e o volume de dinheiro envolvido com a prática criminosa; trazem um perfil das vítimas como inocentes, enganadas e alheias ao que estão sendo submetidas; traçam um perfil dos criminosos como relacionados a redes do crime organizado transnacional, como podemos observar em OIT, 2001; Leal; Leal, 2002; OIT, 2005; UNODC, 2006; Hazeu, 2008; UNODC, 2008; UNODC, 2009; UNODC 2010; UNODC, 2011.

Destacamos que os relatórios são uma importante fonte de dados para a elaboração de políticas públicas, mas que não podemos olvidar que mesmo que os dados não confirmem em números a dimensão destas violações, o importante é saber que o problema existe e que em razão disso é necessário que se tome providências para cessar as práticas criminosas e as violações de direitos.

Por outro lado, algumas pesquisas acadêmicas como em Ferreira, 2009; Ausserer, 2007; Teresi, 2007; Piscitelli, 2008; Santos, 2009; Kempadoo, 2005, Bruckert, 2002; Grupo Da Vida, 2005 questionam os métodos utilizados nos relatórios oficiais para alcançar os dados sobre número de vítimas e valores envolvidos (BRUCKERT, 2002); argumentam que o perfil traçado das vítimas coincide com uma visão machista e patriarcal da mulher, concluem que a maioria dos aliciadores age em pequenos grupos de particulares (não estão vinculados ao crime organizado transnacional), muitas vezes amigos ou parentes das vítimas.

Diante desse conflito de dados, um ponto que merece preocupação é o fato dessas pesquisas e relatórios estarem dando subsídios às políticas públicas que visam a atacar o problema do tráfico de pessoas. Quando se está diante de números supervalorizados que retratam um quadro alarmante de violação de direitos, acaba-se por priorizar essa política. Isso ocorre em razão da urgência em obter-se uma solução rápida, grande soma de dinheiro é investida nas políticas, 
sobretudo em nível internacional. Como os números influenciam as políticas, números equivocados podem produzir políticas equivocadas.

As políticas públicas são bastante guiadas pelos dados quantitativos. Segundo Kempadoo "Políticas, legislação e intervenções de longo alcance são construídas na base da 'evidência', e há uma tendência a aceitar estatísticas e dados não verificados, sem questionamento adicional" (KEMPADOO, 2005, p. 72). Para Tyldon e Brunosviks (2005), nem sempre o que está quantificado em números traz a real dimensão e natureza do problema analisado.

Segundo Santos (2009) "a maior visibilidade conferida a esse fenômeno tem-se traduzido, a nível nacional e internacional, em políticas de combate e prevenção cuja eficácia é discutível" (p. 69). Para Vasconcelos (2009), um dos maiores entraves para uma eficiente pesquisa-diagnóstico é o difícil acesso aos dados advindos dos órgãos de justiça. Para a autora,

"É relevante reforças a necessidade premente de um sistema de cadastramento de dados integrado e responsavelmente alimentado, para que se possa ter acesso rápido e seguro quanto às notificações de delitos e o fluxo dessas notificações. Não é possível construir políticas públicas sem informações reais e seguras da situação de determinado problema." (p. 165, Vasconcelos, 2009)

Para alguns autores, se os números não trazem uma certeza a sua importância deveria ser questionada (PISCINELLI, 2008, KEMPADOO, 2005; TYLDUN; BRUNOSVIKS, 2005, AGUSTÍN, 2005), uma vez que podem levar a políticas inadequadas para atacar o fenômeno do tráfico de pessoas. Fundamental entender o fenômeno a fundo, sem os excessos dos dados superestimados, dos casos extremos, para que se promova uma política eficiente.

Aqui, entendemos que eficiente é a política focada na atenção à vítima, que reconheça sua individualidade, que promova sua cidadania. Mas o que temos visto ao longo dos dois últimos séculos são intervenções que nem sempre priorizam a dignidade humana. 


\section{6 - A Política Nacional de Enfrentamento ao Tráfico de Pessoas}

Cada Estado Parte (...)compromete-se a adotar medidas, tanto por esforço próprio como pela assistência e cooperação internacionais, principalmente nos planos econômico e técnico, até o máximo de seus recursos disponíveis, que visem a assegurar, progressivamente, por todos os meios apropriados, o pleno exercício dos direitos (...), incluindo, em particular, a adoção de medidas legislativas. ${ }^{34}$

O Brasil começa a aderir às ações de enfrentamento ao tráfico de pessoas no ano 2000, por meio de acordos de cooperação com organismos internacionais, sobretudo com o Escritório das Nações Unidas sobre Drogas e Crime (UNODC), à Luz do Protocolo de Palermo. A Secretaria de Direitos Humanos (SDH) acompanhou a elaboração do projeto, repassando os recursos correspondentes à Secretaria Nacional de Justiça (SNJ), que teve a atribuição de coordenar as atividades programadas. A SNJ posteriormente ficou responsável pela gestão e coordenação do Programa de Prevenção e Combate ao Tráfico de Seres Humanos, em 2002.

Em agosto de 2003 o UNODC e o Brasil reformulam os termos do projeto de cooperação, comprometendo-se, o Brasil, a incluir no plano plurianual (PPA) da União de 2004-2007 ações de enfrentamento ao tráfico de pessoas, envolvendo: uma capacitação dos profissionais da rede de atenção e outra para realização de diagnósticos e pesquisas.

Em 2004, a Secretaria Nacional de Justiça iniciou parcerias nos estados e demais ministérios para tornar possível a execução do projeto de cooperação, dando maior visibilidade ao tema do tráfico de pessoas, o que ganhou força com o lançamento da primeira Campanha Nacional de esclarecimento sobre o tráfico de pessoas, em Goiânia, direcionada especificamente ao tráfico de mulheres para fins de exploração sexual. Também em 2004 a Organização Internacional do

\footnotetext{
${ }^{34}$ Artigo 2o, 1, Pacto de Direitos Econômicos, Sociais e Culturais.
} 
Trabalho (OIT) e o Fundo das Nações Unidas para a Mulher (UNIFEM) aderiram à cooperação junto ao Brasil.

No ano de 2005 a Secretaria Nacional de Segurança Pública (SENASP) promoveu em todas as regiões do Brasil, em parceria com a OIT e vários Órgãos do Governo Federal, ampla capacitação para policiais civis, militares, rodoviários e federais sobre o tráfico de pessoas. Neste mesmo ano foi elaborado o "Manual sobre o Tráfico de Pessoas para fins de Exploração Sexual", em parceria com a Organização Internacional do Trabalho (OIT), a Secretaria Nacional de Justiça, o Departamento de Polícia Federal, a Secretaria Nacional de Segurança Pública, a Secretaria de Direitos Humanos, a Secretaria de Políticas para Mulheres e a Procuradoria Federal dos Direitos do Cidadão - do Ministério Público Federal.

Em 2006, num processo de ampliação dos parceiros governamentais, sociedade civil e organismos internacionais a Política Nacional de Enfrentamento ao Tráfico de Pessoas começou a ser esboçada. Ao todo, participaram ativamente das discussões e do trabalho 09 (nove) ministérios, além do Ministério Público Federal e do Ministério Público do Trabalho. Após profícuos debates, a Política Nacional foi instituída pelo Decreto ํㅜ 5.948, de 26 de outubro de 2006, e está dividida em três capítulos.

O capítulo I dispõe sobre a finalidade da política, o capítulo II trata dos princípios e das diretrizes, gerais e específicas, que norteiam a Política Nacional de Enfrentamento ao Tráfico de Pessoas e o capítulo III distribui as ações de competência dos órgãos e entidades públicas evolvidos na política.

A Política Nacional de Enfrentamento ao Tráfico de Pessoas orientou a construção do I Plano Nacional de Enfrentamento ao Tráfico de Pessoas (PNETP), resultado de um grupo de trabalho interministerial. O I PNETP foi aprovado por meio do Decreto no 6.347, de 8 de janeiro de 2008.

O I Plano Nacional foi organizado em três eixos temáticos (Prevenção, Atenção e Repressão), divididos em 11 prioridades com 100 (cem) metas a serem cumpridas. O I Plano vigorou de 2008 a 2010 e deveria ter sido sucedido 
imediatamente pelo II Plano Nacional de Enfrentamento ao Tráfico de Pessoas, que deveria entrar em vigor em 2011 com vigência até 2013.

O processo de elaboração deste II Plano continuou a legitimar o caráter interdisciplinar e participativo da política em questão. A interdisciplinaridade apresenta-se por ter sido construído com a reunião em um Grupo de Trabalho Interministerial (GTI), de 19 Ministérios e Secretarias de Governo, além da Procuradoria-Geral da República e do Conselho Nacional dos ProcuradoresGerais do Ministério Púbico dos Estados e da União. Teve um caráter participativo por ter sido construído a partir de 12 reuniões de trabalho períodicas e uma oficina de diagnóstico sobre os avanços do I Plano com o GTI; 03 (três) colóquios com especialistas, líderes sociais, agências internacionais, Estados e Municípios, e equipes técnicas do sistema de justiça e direitos; análises dos compromissos internacionais do governo brasileiro e das pesquisas sobre o tráfico de pessoas; reuniões bilaterais sobre os Planos Plurianuais (PPAs) de Ministérios e Secretarias; diálogos com a Comissão Parlamentar de Inquérito (CPI) do Senado sobre o tráfico de seres humanos; consulta virtual on-line no site do Ministério da Justiça, com participação de 135 pessoas; 57 plenárias livres com participação de 1500 pessoas, sendo 20 plenárias realizadas em países estrangeiros, além da realização do II Encontro Nacional da Rede de Enfrentamento ao Tráfico de Pessoas em Recife.

Os debates levaram à decisão de reorganizar a Política a partir de Coordenação Tripartite da Política Nacional de Enfrentamento ao Tráfico de Pessoas e o Comitê Nacional de Enfrentamento ao Tráfico de Pessoas CONATRAP, instituída pelo Decreto oㅜ 7901, de 04/02/2013. A Política Nacional passa a ser coordenada pelo Ministério da Justiça, pela Secretaria de Políticas para as Mulheres da Presidência da República e pela Secretaria de Direitos Humanos da Presidência da República.

O II Plano Nacional foi aprovado pela Portaria Interministerial no 634 , de 25 de fevereiro de 2013. Divide-se em cinco Linhas Operativsa (LO), quais sejam: Linha Operativa 1 - Aperfeiçoamento do marco regulatório para fortalecer 0 enfrentamento ao tráfico de pessoas; LO 2 - Integração e fortalecimento das políticas públicas, redes de atendimento, organizações para prestação de 
serviços necessários ao enfrentamento ao tráfico de pessoas; LO 3 - Capacitação para o enfrentamento ao tráfico de pessoas; LO 4 - Produção, gestão e disseminação de informações e conhecimento sobre o Tráfico de Pessoas; LO 5 Campanhas de mobilização para o tráfico de pessoas. 


\section{4 - PROBlema de PESQUisA, delimitaçÃo dO TEMA E OBJETIVOS}

\section{Os Estados Partes do presente Pacto comprometem-se a respeitar a liberdade indispensável à pesquisa cientifica e à atividade criadora. ${ }^{35}$}

Pelo exposto até o momento, o foco em uma política pública é importante para a compreensão do atuar dos profissionais do Direito em uma dimensão outra, diversa da sua atuação corriqueira seja como advogados, juízes, defensores, promotores ou delegados. A atuação dos profissionais do Direito ou de qualquer outro profissional em políticas públicas revela o caráter político das práticas destes profissionais, que conjugam seus saberes com outros saberes, seus valores com outros valores, seus olhares com outros olhares.

Diante do quadro apresentado e das interseções possíveis para a análise do tráfico de pessoas, é preciso que seja lançado um olhar não apenas para os dados, mas para as ações que objetivam o combate ao tráfico de pessoas, por meio de políticas públicas. Para dar subsídios a esta reflexão e usando como tema a Política de Enfrentamento ao Tráfico de Pessoas optamos por definir como questão central a ser desenvolvida na tese: qual a representação social dos profissionais do direito sobre a Política Pública de Prevenção e Enfrentamento ao Tráfico de Pessoas e sobre as vítimas dessa prática criminosa?

Se pudermos compreender os profissionais do Direito como agentes sociais na efetivação das políticas públicas de direitos humanos entendemos ser pertinente questionar esses profissionais: $O$ que os move? Quais as representações sociais constroem sobre os sujeitos por eles protegidos em suas ações em defesa dos direitos humanos? Quais os desafios enfrentados nas ações em defesa desses direitos? Como veem as vítimas? Poderá o Direito ser um fator determinante na valorização da vítima e consecução de ideais de justiça?

\footnotetext{
${ }^{35}$ Artigo 15, 3, Pacto de Direitos Econômicos, Sociais e Culturais.
} 
Entendemos que um estudo com os profissionais do direito que foram ou são membros do Comitê Estadual Interinstitucional de Prevenção e Enfrentamento ao Tráfico de Pessoas do Estado de São Paulo é um caminho possível para começarmos analisar estas questões. Acreditamos que a partir do olhar desses profissionais, é possível propor ações que visem a transformar as políticas, podendo trazer luz sobre as potências e as fragilidades das mesmas, tornando-as mais efetivas, mais garantidoras da tomada de consciência acerca de si e do exercício de cidadania das vítimas. Poderia revelar também o modo como esses profissionais veem os "outros" - vítimas e culpados - nessas relações, num exercício de reconhecimento da alteridade.

Neste ponto, é fundamental justificar a delimitação do âmbito de análise. A primeira delimitação, inicialmente apresentada, é que a pesquisa focalizará a Política Pública de Prevenção e Enfrentamento ao Tráfico de Pessoas. Entendemos ser essa uma política peculiar.

Além das violações de todos os direitos humanos expostas anteriormente, uma característica que merece atenção no enfrentamento a tráfico de pessoas, é o fato de que, se em algumas políticas (como as que zelam pelos direitos das crianças, dos idosos, pela saúde) há uma suposta unanimidade sobre o caráter de vítima dos sujeitos envolvidos, no tráfico de seres humanos, apesar da clara violação dos direitos das pessoas envolvidas, há uma constante criminalização desses sujeitos, sobretudo nas abordagens meramente repressivas.

O preconceito e o tabu que envolvem a prostituição, o desconforto provocado pelos imigrantes irregulares, fazem com que muitas vezes as ações tenham mais um caráter criminal do que social ou humanista. Diante dessa constatação, entendemos que uma análise focada na política de enfrentamento ao tráfico de pessoas pode revelar muito sobre a atuação dos profissionais jurídicos envolvidos na promoção de políticas públicas em direitos humanos.

A segunda delimitação é a do campo a ser investigado. Este estudo irá se restringir à política de enfrentamento no Estado de São Paulo. Em 2004 o Brasil ratificou o Protocolo de Palermo (BRASIL, 2004), em 2006 implementou a política Nacional de Enfrentamento ao Tráfico de Pessoas (BRASIL, 2006) e em 2008 
Iançou o Plano Nacional de Enfrentamento ao Tráfico de Pessoas (BRASIL, 2008) com validade de dois anos. Apesar dos longos debates desenvolvidos ao longo do ano de 2011, com consulta social ampla e direta realizada por meio de consulta virtual e de plenárias livres e dos diálogos do Grupo de Trabalho Interministerial, com participação de especialistas convidados (BRASIL - MJ, 2012), o II Plano foi lançado com mais de dois anos de atraso, por meio da Portaria Ministerial no 634, em 25 de fevereiro de 2013 (BRASIL - MJ, 2013).

Com base na Política e no I Plano, em 12 de março de 2009, foi instituído o Programa Estadual de Prevenção e Enfrentamento ao Tráfico de Pessoas (SÃO PAULO, 2009 - Decreto 54.101/09), vinculado à Secretaria da Justiça e da Defesa da Cidadania do Estado de São Paulo, por meio do Núcleo de Prevenção e Enfrentamento ao Tráfico de Pessoas.

O Programa Estadual de Enfrentamento ao Tráfico de Pessoas tem por finalidade: I - promover ações de prevenção, apoio à repressão e à responsabilização ao tráfico de pessoas; II - garantir a orientação e o atendimento adequado às vítimas dessa prática criminosa e aos seus familiares; III - ser uma fonte de informações técnicas para profissionais e ativistas das áreas de segurança pública e de promoção e defesa de direitos humanos (Decreto 54.101, art. $2^{\circ}$ - São Paulo, 2009).

Para efetivar a Política de Enfrentamento ao Tráfico de Pessoas, dando subsídios para que o Estado de São Paulo consolide as políticas propostas a nível federal, o Núcleo de Prevenção e Enfrentamento ao Tráfico de Pessoas conta com uma equipe operacional multidisciplinar e é apoiado, em caráter consultivo, por um Comitê Interinstitucional de Prevenção e Enfrentamento ao Tráfico de Pessoas. Referido Comitê foi originariamente instituído pela Resolução SJDC oㅡ 308, de 18 de janeiro de 2010. Posteriormente, por meio do Decreto no 56.508 , de 09/12/10, foi alterada a denominação do Comitê, que passou a chamar Comitê Estadual Interinstitucional de Prevenção e Enfrentamento ao Tráfico de Pessoas.

Outra importante passo importante trazido pelo Decreto $56.508 / 10$ foi a oficialização através de Decreto Estadual da instituição de Comitês Regionais. 
Dentro dessa proposta foram criados 15 (quinze) Comitês Regionais Institucionais de Prevenção e Enfrentamento ao Tráfico de Pessoas (CRIPETP), nas grandes regiões administrativas do Estado de São Paulo. ${ }^{36}$ Segundo a coordenadora do Núcleo de Enfrentamento ao Tráfico de Pessoas da Secretaria da Justiça, "Esse decreto vai proporcionar legitimidade para o trabalho de articulação dos comitês e reconhecimento dos agentes frente às autoridades locais" (SÃO PAULO, 2012).

A importância dos núcleos e comitês, que tem uma abordagem multidisciplinar, é a de trazer vários saberes para o Enfretamento ao Tráfico de Pessoas, diversificando as linhas de ação das políticas públicas, numa visão sistêmica do problema. A instituição dos Comitês Regionais visa a estabelecer um sistema descentralizado e participativo, composto por representantes governamentais e não governamentais incumbidos de elaborar, fiscalizar e implementar políticas públicas eficazes para por fim ao tráfico de seres humanos (NETP São Paulo, 2010).

Compõem o Comitê, além de representantes de secretarias de governo (obrigatórios), representantes dos seguintes órgãos, mediante convite: a) Magistratura Federal, do Trabalho, Estadual; b) Ministério Público Federal, do Trabalho, Estadual; c) Defensoria Pública da União, do Estado; d) Ministério da Justiça, por intermédio do Departamento de Polícia Federal e do Departamento de Polícia Rodoviária Federal. Esses últimos representantes são profissionais do direito. Desse modo, a política de enfrentamento ao tráfico de pessoas, com seu caráter multidisciplinar, contempla a participação dos profissionais do direito.

A escolha do Estado de São Paulo ocorre por vários motivos: além de ser o estado mais rico economicamente é importante rota internacional, em razão do Aeroporto de Guarulhos e do Porto de Santos, sendo o estado que mais recebe

\footnotetext{
${ }^{36}$ Importante ressaltar que apesar da oficialização dos Comitês através de Decretos Estaduais terse dado em 2013, os debates e oficinas para a implantação dos mesmos se deu a partir do ano de 2010. Os debates que começaram em 2007 levaram à criação dos Comitês Regionais Interinstitucionais de Prevenção e Enfrentamento ao Tráfico de Pessoas e durante o ano de 2010 , foram feitas diversas oficinas para implantação dos Comitês Regionais, com ampla participação da sociedade civil organizada e do Poder Público em todas as três eixos de ação definidas no Plano Nacional: Prevenção, Responsabilização e Repressão, e Atendimento Integral às Vítimas. (NETP São Paulo, 2010). A Secretaria de Justiça e Defesa da Cidadania publicou entre os dias 20 e 22/02/2013, as Resoluções que instituíram os Comitês nas seguintes cidades: Araraquara, Bauru, Campinas, Guarulhos, Marília, Presidente Prudente, Registro, Ribeirão Preto, Santos, São José da Boa Vista, São José do Rio Preto, São José dos Campos, São Paulo, São Sebastião.
} 
estrangeiros no Brasil e por onde a maior parte dos brasileiros sai do país. O Aeroporto de Guarulhos é por onde chega a maior parte dos brasileiros deportados. Dados de 2004 revelam que dos 22.500 brasileiros (as) deportados(as) ou não admitidos (as), 15 mil retornam ao Brasil via Guarulhos. Dentre as pessoas deportadas, algumas estavam em situação irregular, algumas estavam indocumentadas, e outras foram vítimas de tráfico de pessoas (BRASIL - SNJ, 2006, p. 12).

Importante ressaltar que as ações de prevenção e enfrentamento ao tráfico e pessoas começaram a ser desenvolvidas em São Paulo antes mesmo da instituição da Política Nacional, quando foi realizado o "I Seminário Internacional de Tráfico de Mulheres", em outubro de 2003. Realizado pela Secretaria da Justiça e da Defesa da Cidadania do Estado de São Paulo e pelo Consulado dos Estados Unidos da América, motivou ampla mobilização que levou à criação, em maio de 2004, do primeiro Escritório de Prevenção e Combate ao Tráfico de Seres Humanos para Fins de Exploração Sexual do país, em uma parceria com o Ministério da Justiça por intermédio de sua Secretaria Nacional da Justiça (BRASIL - SNJ, 2006).

Desse modo, destacamos que a escolha do Estado de São Paulo acontece, em resumo, pela sua importância como núcleo econômico, sendo também pioneiro na implantação de ações contra o tráfico de pessoas no país. Além disso, é a unidade da federação em que se dá o trânsito das pessoas que saem e chegam ao país através do aeroporto internacional, sendo ainda local de destino de milhares de brasileiros em busca de um futuro melhor.

Diante da complexidade do tema, observamos que uma análise unilateral, além de não esclarecer todas as dimensões do problema, não abarca todas as possibilidades de enfrentamento. Políticas públicas para enfrentar o tráfico de seres humanos envolvem diálogo e redes de proteção. Um diálogo interdisciplinar é fundamental para que seja possível uma compreensão mais abrangente sobre o fenômeno bem como a implantação de ações mais efetivas (COLARES, 2004). Discussões sobre direito, políticas públicas, atuação dos profissionais do direito, desigualdade e exclusão social, relações de gênero, reconhecimento/identidade, 
violência são algumas das possibilidades de reflexão sobre o tema que exigem um estudo interdisciplinar.

Para Almeida Prado (2010), a importância da interdisciplinaridade se encontra na superação do antagonismo entre conhecimento e objeto pesquisado, feito sem a separação entre saber técnico e o mundo real. Segundo Prado

[...] a interdisciplinaridade enfatiza o homem enquanto ser social (que vive numa sociedade tecnologicamente desenvolvida), dotado de afetividade (que se relaciona $\mathrm{cm}$ sua realidade interna) e com outros seres do meio em que vive. Possibilita, assim, a superação de um tipo de saber feito de especializações formais, o saber em migalhas, 0 saber sem sabor, que provoca a perda da visão da totalidade. (ALMEIDA PRADO, 2010, p. 9)

Uma análise interdisciplinar também é buscada pela Política Nacional de Enfrentamento ao Tráfico de Pessoas, Decreto 5.948 de 06 de outubro de 2006 (BRASIL, 2006), quando institui o Grupo de Trabalho Interministerial com a finalidade de elaborar proposta do Plano Nacional de Enfrentamento ao Tráfico de Pessoas - PNETP. Com base na Política e no Plano, em 12 de março de 2009, foi instituído o Programa Estadual de Prevenção e Enfrentamento ao Tráfico de Pessoas (Decreto 54.101/09), vinculado à Secretaria da Justiça e da Defesa da Cidadania do Estado de São Paulo, por meio do Núcleo de Prevenção e Enfrentamento ao Tráfico de Pessoas, também com caráter multidisciplinar, apoiado pelo Comitê Interinstitucional de Prevenção e Enfrentamento ao Tráfico de Pessoas (instituído pela Resolução SJDC no 308, de 18 de janeiro de 2010 São Paulo, 2010).

Para esta análise interdisciplinar escolhemos utilizar como instrumento a Teoria das Representações Sociais, referencial teórico da Psicologia Social. Japiassu (1976) ressalta que a primeira grande dificuldade em se proceder a uma análise interdisciplinar "reside na própria conceitualização inicial: é extremamente difícil adquirir os conceitos das disciplinas diferentes da nossa". Em razão desta dificuldade, importante se faz tecer alguns comentários sobre a Teoria das Representações Sociais. 
Debates em direitos humanos têm permeado os trabalhos em psicologia social (GUERRA, 2003, JACÓ-VILELA, 2012). Compreender o contexto de existência do sujeito e sua percepção de si e do outro, pareceu-nos ser um caminho para analisar as políticas públicas numa compreensão de que devem ser elas desenvolvidas no sentido de "aplacar a angústia dos que buscam uma explicação satisfatória para os números assustadores e as histórias chocantes associadas a essa modalidade criminosa" (COLARES, 2004, p. 07).

A produção de sentidos é inexistente sem o reconhecimento do outro. A intersubjetividade permite ao sujeito ao mesmo tempo reconhecer-se como único e reconhecer-se como parte de um todo. As representações sociais devem ser conceituadas como conquista da intersubjetividade e devem ser entendidas como um ato de construção, que dialoga com o meio e com o objeto representado. A representação é desse modo, um olhar, que não exclui outros olhares, que não exclui a própria representação que o objeto ${ }^{37}$ tem de si.

Moscovici (1978) apresenta as representações sociais como um conjunto de conceitos, afirmações e explicações que forma uma teoria específica sustentada pela compreensão do senso comum, e que está inserida num universo consensual que comporta opiniões advindas das vivências cotidianas. Seu estudo admite descrever e compreender determinadas práticas do sujeito em relação a situações que enfrenta. Por isso, permite conhecer as maneiras que determinado grupo transforma um novo conhecimento em algo familiar dentro de um determinado contexto histórico e social.

Segundo Banchs (2000a) o indivíduo se constitui e constitui suas representações continuamente e, desse modo, vai compondo sua realidade social e a si próprio a partir dessas representações. Ainda a autora (BANCHS, 2000b) convida a conhecer as representações sociais ressaltando que nenhum conhecimento científico é melhor que um não científico. O ser humano é, sobretudo, um ser em busca de sentido para o vivido, e o faz em sua constante troca com os outros, construindo sua história a partir dos encontros que 0 cotidiano proporciona com os desafios que a vida lhe apresenta.

\footnotetext{
${ }^{37}$ Objeto aqui entendido como foco do estudo, e não como coisa, res, por isso, o "sujeito" representado é aqui colocado como "objeto", mas sem negar a ele autonomia.
} 
Do ponto de vista teórico, a análise da representação social tem permitido desvendar o universo social como forma de conhecimento elaborada e partilhada socialmente. Essa é uma construção cotidiana (TRINDADE, 1996) e tem por finalidade nortear o comportamento e as relações sociais. A partir dela somos capazes de dar um significado pessoal a fenômenos sociais. Segundo Trindade e Enumo (2001), essa teoria, como um instrumento para a produção de conhecimento sobre objetos sociais, tem cumprido um importante papel no desvendamento do sentido, dentre outras coisas, das aparentes contradições que constituem o pensamento social.

Segundo Banchs (2000a), pode-se enfatizar dois tipos de processos presentes na elaboração de uma representação social. São eles: um processo cognitivo que tem caráter individual e o processo de interação que é contextualizado e de caráter social. A mesma autora fundamenta o relevante papel das emoções na construção das representações sociais que é corroborado por Guareschi e Jovchelovitch (2002)

a dimensão cognitiva, afetiva e social estão presentes na própria noção de representações sociais. O fenômeno das representações sociais, e a teoria que se ergue para explicálo, diz respeito à construção de saberes sociais e, nessa medida, ele envolve a cognição. O caráter simbólico e imaginativo desses saberes traz à tona a dimensão dos afetos, porque quando sujeitos sociais empenham-se em entender e dar sentido ao mundo, eles também o fazem com emoção, com sentimento e com paixão. A construção da significação simbólica é, simultaneamente, um ato de conhecimento e um ato afetivo. Tanto a cognição como os afetos que estão presentes nas representações sociais encontram a sua base na realidade social (p. 20).

Pombo-de-Barros (2010), citando Moscovici, ressalta que a história pessoal, a posição que o sujeito ocupa na comunidade e os afetos, ajudam a compor a representação de determinado objeto social, uma vez que para permitir a construção de um conhecimento organizado sobre determinado objeto, esse tem que ser relevante para o grupo que o representa.

Buscando alcançar uma reflexão acerca da atuação dos profissionais do direito em políticas públicas em Direitos Humanos, focando na Política de 
Enfrentamento ao Tráfico de Pessoas e responder à pergunta - qual a representação social dos profissionais do direito sobre a Política Pública de Prevenção e Enfrentamento ao Tráfico de Pessoas e sobre as vítimas dessa prática criminosa? - propusemos os seguintes objetivos:

\section{Geral}

- Investigar qual representação social têm os profissionais jurídicos sobre a Política Pública de Prevenção e Enfrentamento ao Tráfico de Pessoas e sobre as vítimas dessa prática criminosa.

\section{Específicos}

- Investigar de que maneira profissionais jurídicos que são membros do Comitê Interinstitucional de Prevenção e Enfrentamento ao Tráfico de Pessoas analisam a política de enfrentamento ao tráfico de seres humanos.

- Investigar quais os sujeitos tidos como vítimas potenciais no Estado de São Paulo e qual o olhar que os profissionais do direito têm acerca desses sujeitos.

- Conhecer as motivações para o trabalho e a opinião dos profissionais sobre os sujeitos por eles protegidos em sua luta cotidiana pela defesa da dignidade humana.

- Compreender os desafios enfrentados pelos profissionais nas suas ações em defesa dos direitos humanos.

- Analisar se a forma como os profissionais veem a política e os sujeitos nela envolvidos pode alterar a efetividade das mesmas.

- Evidenciar a importância de um olhar interdisciplinar na política pública de enfrentamento ao tráfico humano. 


\section{5 - MÉTODO DE PESQUISA}

\section{1 - Procedimento e Instrumento de Coleta de Dados}

A pesquisa foi realizada através de entrevistas com profissionais jurídicos envolvidos na implantação da Política de Enfrentamento ao Tráfico de Pessoas no Estado de São Paulo. Foram entrevistados 08 (oito) profissionais do direito que no momento da entrevista participavam ou que haviam participado do Comitê Estadual Interinstitucional de Enfrentamento ao Tráfico de Pessoas no Estado de São Paulo.

Para Minayo (2002), no campo, "além do recorte espacial, em se tratando de pesquisa social, o lugar primordial é o ocupado pelas pessoas e grupos convivendo numa dinâmica de interação social” (p. 54). Nesta pesquisa, consideramos a interação social dos sujeitos entrevistados com a própria política de enfretamento ao tráfico de pessoas. Desta forma, a escolha em desenvolver esta pesquisa com os profissionais do direito envolvidos na Política de Enfrentamento ao Tráfico de Pessoas no Estado de São Paulo se justifica tanto em razão do lugar de onde o pesquisador fala - a partir do doutorado em Direitos Humanos na Faculdade de Direito - quanto do lugar de onde os entrevistados falam - sujeitos da política aqui analisada.

A aproximação com os sujeitos para a coleta de dados seguiu alguns passos. Num primeiro momento procuramos contato com os profissionais do Direito envolvidos com a política de enfrentamento ao tráfico, independente de estarem atualmente atuando diretamente na mesma. Essa abordagem foi realizada a partir de contatos feitos no ano de 2010 quando participamos de algumas reuniões do Comitê Regional de Enfrentamento ao Tráfico de Pessoas Baixada Santista. Neste período, em razão de ter recebido e trocado mensagens a partir dos e-mails encaminhados para os participantes das reuniões e membros do Comitê, fizemos um contato inicial através do envio de mensagens, informando 
sobre o doutorado em Direitos Humanos e perguntando se haveria a possibilidade de realizarmos entrevistas sobre a sua atuação na Política de Enfrentamento ao Tráfico de Pessoas do Estado de São Paulo. Obtivemos algumas respostas e selecionamos entre aqueles que responderam os sujeitos que eram profissionais do direito.

Com as respostas positivas acerca da disponibilidade dos profissionais do direito enviamos novamente e-mails a estes possíveis entrevistados explicando o objetivo da pesquisa e a forma como ela seria realizada. A apresentação da proposta de trabalho objetivou esclarecer sobre aquilo que se pretende investigar, as repercussões possíveis que poderão advir da investigação cientifica, a intenção de tornar públicos os dados em artigos, seminários, além da disponibilização do trabalho em banco de dados da Universidade de São Paulo e da CAPES. Estas informações foram importantes para que os possíveis entrevistados se sentissem à vontade para declinar do convite se não se interessassem pelo assunto ou se não confiassem na proposta da pesquisadora. Nenhum profissional, após o envio do e-mail explicativo, recusou-se a dar a entrevista.

Após o retorno aos e-mails, marcamos entrevistas com os profissionais jurídicos disponíveis, visando à coleta de dados. Nas entrevistas, além do objetivo maior de entrevistar os sujeitos, buscamos também junto a eles indicação de mais profissionais envolvidos na política, num sistema de rede, objetivando chegar a outros profissionais que no entendimento dos entrevistados poderiam contribuir para a pesquisa como sujeitos.

Este procedimento é conhecido como técnica Snowball. Segundo Baldin e Munhoz (2011), "essa técnica é uma forma de amostra não probabilística utilizada em pesquisas sociais onde os participantes iniciais de um estudo indicam novos participantes que por sua vez indicam novos participantes e assim sucessivamente, até que seja alcançado o objetivo proposto (o "ponto de saturação"). [...] Portanto, a snowball ("Bola de Neve") é uma técnica de amostragem que utiliza cadeias de referência, uma espécie de rede" (p. 332). Através do uso deste método, chegamos a dois outros sujeitos. 
Nas entrevistas também foram mencionados informantes qualificados. Segundo Patton (2002) apud Begnis et. al. (2007) "Informantes qualificados são entendidos como aqueles que têm uma qualificação específica, seja pela vivência, seja pelo conhecimento sobre a temática" (BEGNIS, et. al. 2007, p. 315). Neste trabalho, consideramos informantes qualificados outros profissionais, sejam do direito ou de outras áreas, que tenham participação importante na Política de Enfrentamento ao Tráfico de Pessoas, sejam membros de instituições públicas, Organizações não Governamentais, pessoas estratégicas na comunidade, pesquisadores.

No procedimento de coleta de dados foi utilizada a entrevista semiestruturada como instrumento, em função do seu caráter interativo, por permitir maiores trocas entre entrevistado e entrevistador e por possibilitar maior interação e desenvoltura dos sujeitos. Segundo Triviños (1987)

podemos entender por entrevista semiestruturada, em geral, aquela que parte de certos questionamentos básicos, apoiados em teorias e hipóteses, que interessam à pesquisa, e que, em seguida, oferecem amplo campo de interrogativas, fruto de novas hipóteses que vão surgindo à medida que se recebem as respostas do informante. Desta maneira, o informante, seguindo espontaneamente a linha de seu pensamento e de suas experiências dentro do foco principal colocado pelo investigador, começa a participar na elaboração do conteúdo da pesquisa (p. 146).

Tal como apontam Lüdke e André (1986), esse tipo de entrevista permite que o entrevistado discorra sobre o tema com base nas informações que detém e que são de fato a razão da entrevista. Becker ressalta a importância de se valorizar "as interpretações que as pessoas fazem da sua própria experiência como explicação para o comportamento. Para entender porque alguém tem o comportamento que tem, é preciso compreender como lhe parecia tal comportamento" (1997, p. 103).

Para Menandro (1998), dois pontos são importantes no percurso de valorização do sujeito na condição de ator social, e que têm implicações metodológicas: a relevância de se ouvir as explicações do sujeito, não restringindo a análise à observação da ação; a valorização de quaisquer 
informações que possam ser extraídas das ações ou de produtos das ações dos indivíduos. Percebe-se dessa forma a importância recentemente dada pelas ciências sociais à vida cotidiana.

Valorizar a atuação dos profissionais na Política de Enfrentamento, e mais, em políticas de direitos humanos, possibilita maior liberdade na interlocução, o que justificou a escolha por uma entrevista semiestruturada. Triviños (1987) alerta para a necessidade de esclarecermos aos entrevistados sobre os objetivos da entrevista, o que se deseja dele e qual pode ser sua contribuição para a pesquisa, além de informar sobre a duração média da entrevista. Estas informações foram passadas tanto através de e-mail quanto através da entrega de uma minuta do projeto a cada um dos entrevistados. Em razão do instrumento de coleta de dados ser uma entrevista semiestruturada, o tempo da entrevista variou bastante, tendo a mais rápida durado 1 h00 e a mais demorada 3:h30min.

Para garantir que dados essenciais de interesse da pesquisa fossem tratados na entrevista, elaboramos uma lista de tópicos que deveriam ser abordados, caso não surgissem de forma espontânea no decorrer da mesma. Os pontos serviram como diretivas para a entrevista que transcorreu prioritariamente deixando o entrevistado livre para falar sobre sua atuação na Política de Prevenção e Enfrentamento ao Tráfico de Pessoas. As intervenções ocorreram apenas para esclarecer alguns pontos e para evitar que detalhes importantes fiquem de fora. Os pontos considerados importantes foram os seguintes:

Sobre Políticas Públicas de Direitos Humanos em geral:

- Dados sobre a carreira e sobre a participação como membro da política pública específica.

- Participação e outras políticas em direitos humanos.

- Percepção sobre direitos humanos

- O que o levou a militar na seara dos direitos humanos: questão burocrática, cumprindo protocolos, ou existe uma "afetação", uma "implicação" na luta por esses direitos?

- O que os mobiliza, no que se refere à atuação nessas políticas. 
- O que pensam sobre os sujeitos por eles protegidos em sua luta cotidiana pela defesa da dignidade humana.

- Quais os desafios enfrentados em suas ações em defesa dos direitos humanos.

- Quais os maiores empecilhos para que as políticas em direitos humanos sejam efetivas.

- Se a forma como os profissionais veem a política e os sujeitos nela envolvidos pode alterar a efetividade da mesma.

Sobre a Política Pública de Enfrentamento ao Tráfico de Pessoas:

- Quem são as vítimas do tráfico de pessoas, que tipo de indivíduo está vulnerável a ponto de ser aliciado pelas redes de tráfico.

- Que lugar essa vítimas ocupam na sociedade.

- Se existe uma rede de tráfico de pessoas.

- Qual a responsabilidade da vítima na sua submissão ao tráfico.

- O que favorece a existência do tráfico de pessoas.

- Quais as maiores dificuldades para o enfrentamento ao tráfico de pessoas.

- Quais as maiores lacunas da política de enfrentamento dão tráfico de pessoas.

- Qual o papel do direito e em especial da profissão do entrevistado na política em questão.

As entrevistas sempre começavam com o questionamento sobre como o profissional inseriu-se na política de Enfrentamento ao Tráfico de Pessoas ou como o profissional iniciou sua atuação em políticas de Direitos Humanos. Optamos por esta questão por entendermos que ao serem chamados a falarem sobre si e sua atuação, criaríamos uma relação de proximidade, o que de fato aconteceu. Quando os profissionais jurídicos foram convidados a falar sobre sua experiência sentiram-se à vontade com a entrevista, reconstruindo sua própria trajetória como profissionais do Direito e como atores envolvidos em políticas de direitos humanos de modo geral, e em especial na política de tráfico de pessoas. Falaram sobre as suas percepções sobre o fenômeno do tráfico, sobre a política, expuseram seu olhar sobre as vítimas, seu olhar com relação aos violadores, trouxeram seus valores, seus anseios. A própria maneira de verbalizar sobre sua 
atuação profissional refletiu o modo como lidam com a realidade do enfrentamento ao tráfico humano. Falando, acabaram por refletir sobre o que perdem e o que ganham com essa experiência, o que os motiva e a relação com a sua profissão.

A partir deste primeiro momento a conversa fluiu naturalmente, de forma espontânea, com intervenções mínimas que fossem estritamente necessárias com vistas a abordar os temas que entendemos serem necessários para o melhor desenvolvimento da pesquisa.

Investigar a atuação dos profissionais jurídicos envolvidos em políticas públicas de enfrentamento ao tráfico de pessoas e possibilitar maior liberdade aos profissionais ao falarem sobre sua atuação, justificaram a escolha por uma entrevista semiestruturada. Esses profissionais estão extremamente familiarizados com o tema, sendo conhecedores de conceitos, das terminologias jurídicas o que pode deixar a entrevista muito técnica. Em razão disso, ressaltamos a importância em deixa-los à vontade, para que pudessem expor-se da maneira mais espontânea possível. Observamos que esta conduta mostrou-se eficiente uma vez que as entrevistas não foram pautadas pelo rigor técnico, muito comum nas falas dos profissionais jurídicos.

Outro ponto que mereceu nossa atenção foi o fato de o clima de espontaneidade criado ter evitado o surgimento de um discurso "politicamente correto" por parte dos profissionais. A preocupação com esse tipo de discurso, pontuado no exame de qualificação, se devia ao fato de que poderia camuflar facetas das representações sociais dos entrevistados sobre o tráfico, sobre as vítimas e sobre suas ações como profissionais do direito em políticas públicas de direitos humanos. Segundo Triviños (1987), deverá o pesquisador "estabelecer um clima de simpatia, de confiança, de lealdade, de harmonia entre ele e o entrevistado" (p. 149), criando um "ambiente que permite a mais ampla expressão de naturalidade, de espontaneidade". (p. 149).

A coleta de dados foi feita por meio das entrevistas semiestruturadas (acima mencionadas), que foram gravadas com autorização de cada participante mediante assinatura do termo de consentimento livre e esclarecido (Anexo). 
Todos os entrevistados aceitaram assinar o termo, sem objeção, tendo recebido também uma cópia do mesmo. As entrevistas ocorreram em dias e horários marcados conforme a conveniência do entrevistado. Todas as entrevistas aconteceram nos locais designados pelos entrevistados, que escolheram unanimemente seus locais de trabalho.

Por fim, é fundamental ressaltar a importância da gravação das entrevistas. A orientação de Triviños é que a entrevista seja gravada por dois motivos: "a gravação permite contar com todo o material fornecido pelo informante" e "o mesmo informante pode ajudar a completar, aperfeiçoar e destacar etc. as ideias por ele expostas, caso o fizermos escutar suas próprias palavras" (1987, p. 148). Ainda, sobre a importância em se gravar as entrevistas, Queiroz (1991), ressalta que esse procedimento serve para que nenhum momento da entrevista se perca, "uma pausa do informante, uma tremura de voz, uma tonalidade diferente" (1991, p. 87), permitindo ao pesquisador atentar-se para "aspectos da entrevista que não haviam sido lembrados" (op. cit, p. 87).

\section{2 - Procedimento de Análise dos Dados}

A análise dos dados proposta é de natureza qualitativa, visando a privilegiar as idiossincrasias dos sujeitos, sua atuação na política pública de enfrentamento ao tráfico de pessoas e seus pontos de vista sobre as políticas e as vítimas, suas motivações, seus anseios, suas percepções. Para Minayo (1999), pesquisas qualitativas

são entendidas como aquelas capazes de incorporar a questão do SIGNIFICADO e da INTENCIONALIDADE como inerentes aos atos, às relações, e às estruturas sociais, sendo essas últimas tomadas tanto no seu advento quanto na sua transformação, como construções humanas significativas. (p. 10) 
A mesma autora faz a seguinte observação:

A rigor, qualquer investigação social deveria contemplar uma característica básica de seu objeto: o aspecto qualitativo. Isso implica considerar sujeito de estudo: gente, em determinada condição social, pertencente a determinado grupo social ou classe com suas crenças, valores, significados. Implica também considerar que o objeto das ciências sociais é complexo, contraditório, inacabado, e em permanente transformação. (p. 22)

Como já dito, as entrevistas foram gravadas. Visando rememorar e aprofundar o contato com o conteúdo das entrevistas, a transcrição das mesmas foi realizada pela pesquisadora, atendendo o proposto por Queiroz (1991). Após transcritas, foi feita uma leitura exaustiva das entrevistas visando a maior aproximação possível com o conteúdo. O caráter qualitativo da análise justifica este procedimento, uma vez que só uma leitura atenta e repetitiva permite uma apropriação do conteúdo das falas dos sujeitos. Nesse tipo de análise, privilegiam-se as peculiaridades das visões dos sujeitos sobre a Política de Enfrentamento ao Tráfico de Pessoas. Bardin (1979) aponta a importância de uma análise atenta e fecunda dos dados, evitando equívocos quanto à interpretação do conteúdo em análise ao mesmo tempo em que possibilita retirar dos dados todo o seu potencial.

Os dados foram submetidos à análise de conteúdo, proposta por Bardin (1979), utilizando-se categorias de análise encontradas nas respostas dos sujeitos, condizentes com os objetivos do trabalho.

Essa potencialização da análise dos dados foi alcançada por meio da concretização de três objetivos: ultrapassagem da incerteza, que se dá quando o pesquisador consegue uma análise sem se misturar aos dados e efetua uma leitura isenta e generalizável; enriquecimento da leitura, que ocorre pela exaustão, quando o pesquisador se livra dos imediatismos da primeira leitura; por fim, integração das descobertas, percebendo aquilo que está além das aparências, localizado num quadro de totalidade social em que a mensagem se insere.

Para efetivação da análise dos dados, nos aportamos na análise temática, proposta por Bardin (1979), que contem três etapas: pré-análise, que compreende 
a organização dos dados e a eleição de um eixo condutor da análise; exploração do material, que consiste na transformação dos dados brutos, visando a alcançar o núcleo de compreensão do texto e por fim, tratamento dos resultados obtidos e interpretação, onde se retomará o arcabouço teórico e buscar-se-á os significados dos discursos e sua importância para a análise do tema proposto.

A análise de conteúdo, segundo Minayo (1999), visa a uma articulação entre significantes e significados, analisando as variáveis psicossociais, culturais, o contexto e o processo de produção da mensagem. A análise de conteúdo possibilita a percepção do discurso como forma de expressão sujeita a influências externas:

[...] o discurso não é um produto acabado, mas um momento de criação de significados com tudo o que isso comporta de contradições, incoerências e imperfeições. Leva em conta que, nas entrevistas, a produção é ao mesmo tempo espontânea e constrangida pela situação. (Minayo, 1999, p. 206).

Para a efetivação da análise de conteúdo, procedemos da seguinte forma:

Num primeiro momento, após a transcrição integral da entrevista, seguida de leitura exaustiva, buscamos identificar unidades de significado que são, segundo Trindade (1991) "os aspectos das falas dos participantes que consideramos importantes para o nosso objetivo" (p. 36). Essas unidades surgiram dos pontos em comum na fala dos participantes. Elementos que apareciam de forma recorrente nas falas dos entrevistados foram identificados e nesta fase agrupados em um único documento, de maneira aleatória. Para facilitar a identificação do autor das falas, cada entrevista foi colorida de uma cor diferente, para que, ao organizar estes dados, pudéssemos definir sua autoria.

Após tais etapas de fragmentação acima descrita, construímos um texto para cada categoria, estabelecendo elos entre as falas. Optamos por apresentar 0 conteúdo não através de um texto para cada entrevistado, mas através de textos representativos das categorias. A razão desta escolha se justiça pela tentativa de preservar ao máximo a identidade dos entrevistados. Num texto em que as falas são agrupadas, mesmo que haja a identificação do autor de cada fala, a mescla 
da fala de um sujeito com a fala de outro, dificulta a identificação das falas. Optamos por nomear os entrevistados como Participantes, que no texto de apresentação dos dados aparecem como P1 a P8. Não esclarecemos na apresentação dos dados qual profissional estava falando, se advogado, juiz, promotor, defensor ou delegado. Em alguns momentos, no entanto, a própria fala revelava a profissão do entrevistado, mas sem maiores relevâncias.

$\mathrm{Na}$ construção dos textos de cada categoria optamos por fazer várias transcrições das falas, por trazerem conteúdos bem estruturados, fato justificado pela formação dos entrevistados. Esta transcrição das falas restringiu-se àquelas tidas como relevantes.

As categorias pinçadas das falas dos entrevistados foram as seguintes:

Categoria 1 - Autorretrato: O olhar dos profissionais do Direito sobre si mesmos

Categoria 2 - Vulnerabilidades: Violência como causa e como consequência do tráfico de pessoas

Categoria 3 - Desafios: Maiores dificuldades em trabalhar o tema tráfico de pessoas e Direitos Humanos

Categoria 4 - Vítimas: os sujeitos/objetos do tráfico de pessoas

Categoria 5 - Articulação - Os eixos temáticos e a intersetorialidade da política

Optamos por realizar a análise e discussão dos dados no corpo do texto de cada categoria, objetivando facilitar a leitura do conteúdo apresentado. Deste modo, entre as falas organizadas nas categorias, realizamos a análise e trouxemos o referencial teórico que embasou as discussões.

Por fim, esclarecemos que foram entrevistados oito profissionais do Direito, sendo três advogados, um juiz, um delegado da Polícia Civil, dois promotores de justiça e um defensor público da União. Todos os profissionais atuam em seus cargos há pelo menos 10 anos. Todos os entrevistados participam ou 
participaram em algum momento da Política de Enfrentamento ao Tráfico de Pessoas no Estado de São Paulo, como membros do Comitê de Enfrentamento ao Tráfico de Pessoas do Estado de São Paulo. Os advogados participaram como representantes de Organizações Não Governamentais e os demais entrevistados como representantes das Instituições às quais estão vinculados. Dos oito profissionais entrevistados, cinco acompanharam a política desde sua implantação, sendo que dois deles, no momento da entrevista ainda faziam parte do Comitê. Três dos entrevistados começaram a fazer parte do Comitê a partir de 2010. Daqueles que não fazem mais parte do Comitê um saiu para assumir outras atribuições em seu órgão de origem e os demais em razão da reformulação da política no Estado, que teve início em 2010. 


\section{6 - APRESENTAÇÃO, DISCUSSÃO E ANÁLISE DOS DADOS}

\section{1 - Categoria 1 - Autorretrato: O olhar dos profissionais do Direito sobre si mesmos.}

Esta categoria, nomeada "Autorretrato: O olhar dos Profissionais do Direito sobre si mesmos", traz, da fala dos entrevistados, a forma como veem a atuação dos profissionais do Direito nas ações em Direitos Humanos e na Política de Enfrentamento ao Tráfico de Pessoas. A todos os entrevistados foi, no decorrer da entrevista, em algum momento solicitado que falasse sobre de que maneira veem a atuação de sua profissão na política. Em alguns momentos, a fala abrange além da profissão específica do entrevistado, as profissões jurídicas de uma maneira geral. Em alguns momentos também, o discurso ganha uma dimensão mais genérica, não se restringindo à atuação dos profissionais do Direito na política de enfrentamento ao tráfico de pessoas.

Nesta categoria são apontados os pontos positivos, as lacunas e os desafios das profissões jurídicas no seu exercício diário, pelo olhar dos entrevistados.

Um dos primeiros pontos que nos chama a atenção na fala dos entrevistados refere-se à inevitável constatação de que o profissional do direito é antes de tudo um indivíduo, com sua história, que chega à profissão carregado de valores e preconceitos que podem impregnar sua atuação. É o que observamos na fala de P1

O que acontece, antes de serem operadores de direito, em seus respectivos espaços de poder, seja como juízes, delegados de polícia, promotores, advogados, cada um desses atores é um ser humano e cada um desses seres humanos, juízes, promotores, etc., eles são construídos e são formados e a sua formação humana vem carregada de uma série de preconceitos, de discriminações e muitas 
vezes estes sujeitos nas suas atuações eles transpõem para a sua prática, a suas vivencias pessoais. (P1)

A fala do entrevistado nos leva a uma reflexão sobre a dimensão humana do profissional do Direito. O olhar do profissional pode ser ampliado a partir de uma formação jurídica que propicie reflexão sobre alteridade, a partir de um olhar para os direitos humanos. Uma formação que ressalte a presença dos direitos humanos nos lugares comezinhos, nas relações jurídicas mais banais e também nas grandes decisões judiciais. A formação atenta à ética da alteridade, "numa nova compreensão da solidariedade, entendida como um sentimento de autêntico cuidado com o outro" (SENA, 2010, p. 17). É o que propõe Luis Alberto Warat, advogado e psicanalista, ao refletir sobre a formação jurídica

Temos que aspirar à dignidade total da existência. Nosso compromisso com a vida passa por pensar e atuar procurando gerar homens melhores, homens que se preocupem com a produção social da dignidade. Para que exista uma forma social democrática, a dignidade tem que ser algo que se possa respirar constantemente. E todos temos que ajudar para que o outro possa reconhecer, em nós, sua dignidade. (2004, p. 388)

A formação pautada nos Direitos Humanos pode evitar que nas práticas o profissional do direito reproduza preconceitos, como pontuou P6 em sua fala

...você vai sentir que há o preconceito dos agentes do estado, se você cair no Ministério Público, há o preconceito até contra as mulheres, o preconceito ele é velado mas ele existe, porque a gente vê promotores e promotoras se referindo às vítimas de violência doméstica como umas burras. A mulher que apanha é porque quer apanhar... (P6)

O preconceito é também pontuado por $\mathrm{P} 3$, quando reflete sobre a criminalização de alguns setores da sociedade.

Toda aquela ideia de rotulação da teoria criminológica. A criminalização da pobreza. E criminalização de alguns setores. O sistema de justiça criminal é seletivo. Isso é nítido, a porta de entrada é quantitativa, a saída é qualitativa. Quem são os tipos que a polícia aborda, são aqueles estereótipos. Há um estereótipo. No imaginário popular e a polícia reflete a população. (P3) 
Esta observação reforça a ideia de que uma formação focada nos Direitos Humanos poderia abrir uma perspectiva de reflexão da prática, atenta às diversidades e à dignidade humana. Ao apontar que há estereótipos que preferencialmente são criminalizados pela polícia e ressaltando que este estereótipo reflete o imaginário da população, podemos inferir que a população elege seus "mocinhos" e seus "bandidos" e a formação dos profissionais descomprometida com os ideais humanistas somente legitima este ponto de vista e faz com que as práticas reproduzam estes padrões, só que agora com o poder coercitivo do Estado.

Tudo isto é alcançado através da criminalização da pobreza e brutalização dos pobres. A incriminação parece estar emergindo como o principal substituto da sociedade de consumo para o rápido desaparecimento dos dispositivos do estado de bem-estar. "A penalidade neoliberal apresenta o seguinte paradoxo: pretende remediar com um 'mais Estado' policial e penitenciário o 'menos Estado' econômico e social que é a própria causa a escalada generalizada da insegurança objetiva e subjetiva em todos os países" (WACQUANT, 2001, p. 07).

A relação entre criminalidade e pobreza gera estereótipos e preconceito. Esta vinculação é apontada por Sérgio Adorno quando analisa o discurso de justiça social e igualdade jurídica, num país que não alcançou nem a justiça social nem a igualdade jurídica. Para o autor, "a distribuição da justiça acaba alcançando alguns cidadãos em detrimento de outros, o acesso da população aos serviços judiciais é dificultado por razões de diversas ordens e, muito dificilmente as decisões judiciárias deixam de ser discriminatórias" (ADORNO, 1994, p. 134).

Para Bauman, a sociedade justa só seria alcançável pela eliminação do impedimento à distribuição equitativa das oportunidades trazidas pelas sucessivas demandas por reconhecimento. A única forma de definir quais valores devem ser priorizados é dar a todos a oportunidade de defender e fundamentar seus interesses.

A oportunidade de dar a todos a chance de expor e de defender suas reivindicações e pontos de vista, só ocorrerá em um Estado verdadeiramente democrático: 
Não é preciso mencionar que o problema da justiça não pode ser sequer postulado a menos que já haja um regime democrático de tolerância que assegure, em sua constituição e prática política, os direitos humanos - ou seja, o direito a conservar a própria identidade e singularidade sem risco de perseguição. Essa tolerância é uma condição necessária a toda justiça. $O$ ponto principal, porém, é que não é a sua condição suficiente. Por si mesmo, o regime democrático não promove (e muito menos assegura) a transformação da tolerância em solidariedade (BAUMAN, 1998, p. 82).

Não podemos apontar como única culpada, a ética, ou a "morte do conhecimento e entendimento ético" pelas catástrofes humanas. Também não podemos definir que a mudança de paradigmas, de comportamento, de valores seja garantida a partir de uma formação pautada em ideais humanistas. Mas, a formação, a sensibilização, a capacitação podem ser passos importantes para o começo de um caminhar rumo à promoção da dignidade humana nas práticas dos profissionais do Direito. Para P6, a atuação dos profissionais pode ser alterada positivamente a partir da transformação do indivíduo.

Eu acredito em duas coisas: essa campanha geral e na transformação do indivíduo, eu acho que a gente tem que fomentar a transformação do indivíduo. Se a gente não transformar 0 individual a gente não vai transformar 0 coletivo. Se a gente não admitir, não chegar para uma pesquisadora que existe um preconceito, ele tá aqui, ele tá no meu vizinho... existe um preconceito para quem é contra o preconceito. (P6)

A transformação do individual como requisito para a transformação do coletivo também pode passar pela formação, pela educação em direitos humanos. Para Weingartner Neto e Sarlet (2010),

A educação (abrangendo ensino e pesquisa) e a formação para uma vida com dignidade e, nesse contexto, uma educação para os direitos humanos e fundamentais, constitui tarefa (dever constitucional) irrenunciável do Estado e da Sociedade, no âmbito de todas as suas unidades, sendo mesmo possível afirmar que a educação para os direitos humanos e fundamentais integra o que se tem designado de um mínimo existencial sociocultural. (p. 421) 
As transformações podem materializar-se em atuações específicas de algumas das profissões jurídicas. Algumas ações são apontadas como de grande importância na efetivação de políticas em Direitos Humanos. Segundo P7

Quanto ao papel dos profissionais do direito, tanto a defensoria quanto o Ministério Público podem entrar com ação civil pública, e uma das atribuições de tudo isso é um controle externo das políticas públicas. Não só no trabalho no judiciário, mas pode influenciar também no executivo. Tanto fazendo tudo o que é feito no comitê, indicando, vendo qual a importância das políticas públicas novas, de como tem que ser complementadas, tanto nas ações reais, no dia a dia, de ações judiciais, para que a política pública funcione, para que exista uma política pública, para que ela seja criada. É um controle direto. (P7)

Da fala do interlocutor percebe-se que a atuação dos profissionais do direito nas políticas públicas é vista como importante em sua dimensão operacional, quando os profissionais são chamados a compor os órgãos responsáveis pelas políticas, e também quando se mostram, em suas práticas, sensíveis à criação e efetiva implementação das mesmas, atentos e fiscalizadores de seu funcionamento. Esta posição é relevante por mostrar que o profissional amplia a percepção da atuação dos juristas para além dos processos judiciais, reconhecendo a dimensão política das suas práticas.

Essa opinião é referendada pelo Ministério Público do Estado de São Paulo quando define seu papel na luta contra o tráfico de pessoas. Além da atuação na área criminal, proteção à vítima, atendimento ao público, violência doméstica, infância e juventude, saúde pública e assistência social, há previsão da judicialização das políticas públicas, como se depreende pela leitura do texto abaixo

O Ministério Público tem a sua disposição mecanismos para impulsionar a melhora da qualidade e de resultado da política de atendimento às vítimas. Dentre os instrumentos merecem destaque o inquérito civil e a ação civil pública, hábeis a possibilitar não somente o controle, mas principalmente o diálogo com o Estado e a sociedade civil, e cujo objeto pode ser a adoção de uma política pública, tanto na área da infância e juventude, como também na saúde, no trabalho, na defesa dos direitos humanos. O Ministério 
Público pode e deve se posicionar como mediador e interlocutor na relação sociedade e Estado. ${ }^{38}$

A participação da sociedade civil é requisito na elaboração das políticas públicas e se mostra fundamental para que as mesmas se tornem eficazes. Junto a isto, não se pode desprezar a importância do Ministério Público, da Defensoria Pública e dos advogados - constitucionalmente reconhecidos como indispensáveis à administração da justiça - como fundamentais para o aprimoramento da democracia participativa, aqui consubstanciada na participação nas políticas púbicas. A participação do Ministério Público é ressaltada por Dal Bosco, 2009:

A implementação de direitos fundamentais sociais por parte
do Estado tem sido a cada ano mais negligente, o que
resulta em dificuldades praticamente instransponíveis para
alguns setores da população brasileira, especialmente os de
classes econômicas mais baixas. A garantia dos direitos tem
sido relegada a poucos mecanismos e instituições. E nessa
tarefa, a participação do Ministério Público é fundamental,
enquanto fiscalizador da ação administrativa, no sentido de
que ela obedeça à legislação, e na responsabilização de
administradores que se conduzem mal, assim como
interferindo para que a coletividade receba as prestações
garantidas pela Constituição Federal. (p. 32$)$

Esta atuação política acaba por exigir do profissional um maior envolvimento com os propósitos das políticas públicas. Para alguns entrevistados, a atuação em Direitos Humanos exige do profissional um perfil diferenciado e uma vivência comprometida. É o que observamos na fala de P2

Ele precisa sentir. Acho que os Direitos Humanos são uma coisa que você precisa internalizar, para você poder aplicar. (P2)

Entender que a atuação em Direitos Humanos exige um sentir, uma internalização, revela o quanto a promoção da dignidade humana tem como imprescindível o olhar para o outro, o reconhecimento de que, no dizer de Warat acima citado, "todos temos que ajudar para que o outro possa reconhecer, em nós, sua dignidade". A atuação do profissional, então, para atuar em direitos

\footnotetext{
${ }^{38}$ Texto disponível em http://www.mpsp.mp.br/portal/page/portal/cao civel/Trafico de Pessoas, acessado em 10/10/2013.
} 
humanos, acaba por exigir um caráter quase que vocacional, no entendimento de alguns entrevistados. Por isso, a escolha do profissional tem que ser consciente e atenta a esta afinidade com o propósito. Segundo P3, para ocupar cargos que tratem de Direitos Humanos é fundamental ter um olhar sensível ao outro, é necessário

Identificar perfis. Não adianta por ali pessoas que não tenham uma visão em Direitos Humanos. Estrategicamente, para valorizar a divisão que trata de Direitos Humanos, é preciso enxergar a vocação do profissional. O atrativo não é ter que criar um adicional para quem vai trabalhar com Direitos Humanos. Ponha-se no lugar do outro, respeite a vocação. Não é qualquer indivíduo que vai ter este olhar sensível para o outro, não tem que pensar que todo mundo tem que fazer a mesma coisa, tem que descobrir as competências de cada um, tem que ver o perfil. (P3)

A atuação do profissional do Direito que vai atuar em políticas de Direitos Humanos, mais uma vez aparece como exercício de alteridade na fala de P2, quando perguntado sobre como auxiliar o profissional a internalizar a dignidade humana como uma meta, responde:

Não é fácil, é um exercício diário, é você se empoderar tecnicamente, é você começar a fazer um exercício de transpor-se e colocar-se no lugar do outro, é uma gama de coisas. É um exercício, como dizem os orientais, é um exercício de benevolência. Você se colocar no lugar do outro, vestir o manto da compaixão. Eu acho que esse é o grande desafio. (...) Quando você começa, não só a militar, mas vivenciar direitos humanos, viver no sentido mais amplo e no sentido humanístico do tema, você passa a uma mudança atitudinal, no seu refletir, no seu criticar, no seu pensar, no seu vivenciar. (P2)

A alteridade aparece também na fala de P3

Quando você traz o problema para você, é a tal da alteridade, coloque-se no lugar do outro. (...) Se a autoridade é perversa e cultua desvalores, como é que os agentes de autoridade vão se comportar, porque na hierarquia não conseguem se insurgir. Isso está mudando. (...) A instituição lida com a questão dos Direitos Humanos formalmente, materialmente, mas tem um outro lado, que é a preocupação com o outro. É comum tirar o problema da frente. Não resolve, desvia do problema. (P3) 
Este perfil do profissional que trabalhará com Direitos Humanos em muitas falas aparece como vocação. É o que podemos observar na fala de P4.

Eu digo que para trabalhar com direitos humanos nós temos que ter outro requisito, que é a vocação, que também não pode ser trabalhado sozinho, precisa reunir o amor e o dinheiro, mas precisa ter vocação. Se eu não tiver vocação pra coisa... (...) A vocação é algo que precisa ter. Eu vejo estas pessoas que trabalham, até porque não resistiriam pelo que presenciam, eu acho que a gente vê muitos absurdos, mas ver ali, na cara do gol, ela testa sua vocação. Eu acho que algumas pessoas vão por interesse, ou porque são nomeadas, ou porque - vou ser muito sincero, tem ou teve há um tempo atrás em que alguns órgãos, porque não tinha ninguém mandava qualquer um, é o que eu vejo muitas vezes em conselhos de cidadania, que ao verem que não têm ninguém, manda fulana, que não vai fazer falta no trabalho -, porque ainda não vê o Tráfico de Pessoas como algo importante. Mas também estas pessoas que vão sem vocação, também não conseguem resistir por muito tempo. (...) Eu vejo que o interesse destes profissionais é por vocação. Ali você não tem só o técnico. Você tem além da vocação um sentimento próprio, que é trabalhar com a fragilidade humana. (P4)

A vocação, tratada como comprometimento e ideologia, aparece também na fala de $\mathrm{P} 1$

É uma questão de comprometimento com a causa. Eu acho
que a questão dos Direitos Humanos é uma questão
ideológica por excelência, ideológica no sentido de você
enxergar o ser humano como toda a convergência, tudo
converge para o ser humano. Eu acho que há um
comprometimento com esta ideologia e pensando como ser
humano muito antes de pensar como promotor ou qualquer
coisa, acho que há uma crença no ser humano, um respeito
ao ser humano. A questão dos direitos humanos é antes de
você protegê-los, promovê-los. É o discurso da promoção e
eu acho que para você transpor isto para a função que você
exerce, é você instrumentalizar esta crença a serviço da
própria humanidade. Pode ser uma visão romântica, embora
eu ache que não seja, mas acho que é uma questão de
absoluta coerência e comprometimento com aquilo que você
quer para si mesmo. (P1)

Sugerimos que o termo vocação seja entendido com cuidado uma vez que entendemos que o sujeito é um ser sócio-histórico e que se constrói nas relações, 
que vai se apropriando do universo ao seu redor, em um imbricado processo de constituição de si e do mundo. Neste viés, acreditamos que os processos de formação, sensibilização e capacitação podem ser eficientes para estabelecer comportamentos que legitimem a efetividade dos direitos humanos. Neste entendimento, não só se nasce vocacionado, mas também se constrói o reconhecimento do valor da dignidade pelas práticas.

Mas, o Estado Democrático não é certeza de garantia da efetividade dos direitos humanos. "A preocupação com direitos humanos não é a função do Estado. É uma instituição não estatal dentro do estado - um apelo à humanidade que o Estado ainda não consumou. A preocupação com os direitos humanos é um apelo ao "excedente de caridade" (LEVINAS, apud BAUMAN, p. 67). Para o autor, a macroética (justiça) necessita da microética (moral) para existir.

Não se pode vincular unicamente o estabelecimento de políticas públicas à boa-vontade ou às benesses dos agentes públicos. As políticas são prescrições que têm de ser obedecidas e não podem estar condicionadas ao perfil do executor. Em trabalho anterior (FRINHANI, 2004), enfrentamos o mesmo questionamento ao analisarmos a política penitenciária ${ }^{39}$.

A ideia de vocação acaba por levar à compreensão de que as políticas seriam entendidas como um favor (TELLES, 1990), dependente da boa vontade dos agentes. Ocorre que as politicas devem ser encaradas como direito, que como tal deve ser reconhecido e garantido independentemente de boa vontade. $O$ cumprimento da lei deve estar amparado por remédios que garantam a sua efetividade e não somente condicionada aos valores do agente público responsável por sua consecução.

Junto a esta ideia de vocação que permeou a fala dos entrevistados, observamos que é constante a reflexão sobre a importância da formação e da capacitação dos profissionais do Direito. Em alguns momentos os profissionais ressaltam as boas práticas de algumas instituições em instituir em seus cursos de formação, cadeiras sobre Direitos Humanos e também sobre Tráfico de Pessoas.

\footnotetext{
${ }^{39}$ Em referido trabalho, foi observado que o cumprimento da lei no que se refere ao direito das detentas ao trabalho, era apresentado como um favor e não como uma política penitenciária.
} 
Dar visibilidade ao tema é uma das justificativas para a introdução do conteúdo e uma das metas institucionais para promoção dos Direitos Humanos. É o que observamos na fala de P1:

$\mathrm{Na}$ escola do Ministério Público o tema tem sido pautado com certa frequência, ano passado teve o primeiro curso de especialização sobre Direitos Humanos em que um dos temas era o Tráfico de Pessoas e nós preparamos 13 oficinas para este ano, em todo estado de São Paulo, junto da escola do Ministério Público, para capacitar todos os promotores e servidores em relação ao tema Tráfico de Pessoas. Nós vamos fazer aí uma espécie de oficina que vai durar meio período, uma manhã, que o objetivo é justamente despertá-los para o assunto. Eu vejo o MP como uma instituição absolutamente preocupada comprometida, intensamente envolvida com a causa dos Direitos Humanos. (P1)

A capacitação é uma preocupação também para P3

nas polícias do Brasil a gente tem que fazer, capacitação, capacitação e capacitação, a gente tem que alertar para o tema, porque infelizmente em polícia, Direitos Humanos é algo secundário. Na policia de São Paulo hoje a gente tem cadeira de Direitos Humanos na Academia de Polícia, nós temos o centro de Direitos Humanos. (...) Então já há uma preocupação como tema. Mas por exemplo, não se exige, embora haja recomendações, que se crie a cadeira de Enfrentamento ao Tráfico de Pessoas, não tem. Você acaba tendo que falar em palestras, quanto mais se divulgar o tema... eu dou sempre um jeito de, na minha matéria (...), eu dou sempre um jeito de inserir 0 assunto. (P3)

Para este profissional, a mudança de comportamento pode se dar a partir da formação:

Em geral não recebem tratamento de nada, numa feição repressiva, vendo o outro como inimigo. Hoje não, você tem que ter a visão de que o cidadão é um cliente, é um usuário do serviço público, é essa concepção. Como se muda isso? $\mathrm{Ou}$ é disciplinarmente, com os meios disciplinares e repressivos, e com capacitação, com formação, com cursos de formação e complementares, alertando para o tema. (P3)

P4 questiona sobre como as capacitações chegam até o profissional. 
A minha preocupação em relação a este conteúdo é: os policiais compreendem isso? Ou eles falam porque 0 superior hierárquico mandou eles falarem ou porque tem que responder na prova? (P4)

Para P1, a capacitação tem que ser constante, para que seja efetiva

É como se fosse um pulsar, você tem que ter o pulsar o tempo inteiro, senão a coisa não flui. (P1)

A efetividade pode ser alcançada também com a simplicidade das ações e como direcionamento correto, na opinião de P5.

Fazer uma cartilha bem simples, uma coisa bem fácil, uma tipificação bem simples das condutas, e capacitar os investigadores. É simples, barato e eficaz, não precisa gastar rios de dinheiro, fazer grandes congressos. Para 0 atendimento de ponta. Aí você vai ter bons frutos. (P5)

Importante ressaltar que a capacitação aparece como prioridade no I Plano Nacional de Enfrentamento ao Tráfico de Pessoas ${ }^{40}$ (BRASIL, 2008) e como objetivo no II Plano Nacional de Enfrentamento ao Tráfico de Pessoas ${ }^{41}$ (BRASIL, 2013). Sabendo que os entrevistados participam da política e por isso conhecem bem seus documentos normativos, não podemos deixar de considerar que a definição da capacitação como prioridade, objetivo e meta os dois planos, pode justificar o fato dos profissionais terem quase que de maneira unânime colocado a capacitação como ponto importante.

Não se pode desprezar, no entanto, que a atuação junto a um tema pouco conhecido e que muitas vezes é tido como "lenda urbana", exige uma divulgação e sensibilização dos olhares, para que os profissionais da Justiça, do Ministério Público, da saúde, assistência social e outros, identifiquem e encaminhem os casos para a melhor solução, que preserve a vida e a dignidade das vítimas, a

\footnotetext{
${ }^{40}$ O Eixo Temático I - Prevenção ao Tráfico de Pessoas, traz como prioridade 2: “Capacitar e formar atores envolvidos direta ou indiretamente com o enfrentamento ao tráfico de pessoas na perspectiva dos direitos humanos". A capacitação deverá se dar através da realização de cursos e oficinas, com a produção de material de referência, quando necessário, para profissionais e agentes específicos.

${ }^{41}$ Portaria Interministerial no 634, Art. 20 São objetivos do II PNETP: IV - Capacitar profissionais, instituições e organizações envolvidas com o enfrentamento ao tráfico de pessoas. O II Plano definiu Linhas Operativas, estabelecendo a capacitação na Linha operativa 3 - Capacitação para o enfrentamento ao tráfico de pessoas. Na meta 3.A.25, o II Plano estabelece que Servidores do sistema de justiça e do Ministério Público que trabalham com o tema do tráfico de pessoas priorizados na inserção em programas de capacitação.
} 
responsabilização dos agentes violadores e a identificação de vulnerabilidades que possam ser minimizadas pela prevenção.

A capacitação aparece como uma necessidade para que os agentes públicos (profissionais do direito ou não) consigam enxergar as violações de Direitos ou o Tráfico de Pessoas. Para P3, a invisibilidade e o desconhecimento sobre o Tráfico de Pessoas ficaram claros no caso do menino haitiano que foi vítima de tráfico e foi encontrado perdido numa rodoviária de São Paulo.

Então, por exemplo, o caso do menino haitiano, ele passou por uma delegacia de polícia e falaram que não era problema de polícia, que era problema social. Porque não sabe: menino negro, falando francês na estação CorinthiasItaquera, o metrô não está preparado para isso. Levaram para a delegacia, de Conselho Tutelar em Conselho Tutelar, passaram alguns dias até se chegar ao conhecimento do Núcleo de Enfrentamento ao Tráfico de Pessoas, porque aí atua rede. O rapaz está aqui desde 2009. É um crime transnacional, envolve estados, soberania, aí começa a diplomacia. (P3)

O "caso do menino haitiano" foi amplamente divulgado pela mídia nacional $^{42}$. O garoto tinha 11 anos quando chegou ao Brasil. Foi abandonado no metrô de São Paulo, em dezembro de 2009, por uma quadrilha de coiotes, que foram contratados para levar o menino para a Guiana Francesa para encontrar sua mãe. Após ser encontrado, passou três anos em um abrigo esperando para voltar para casa e somente em dezembro de 2012 conseguiu reencontrar a mãe que morava na Guiana Francesa já fazia 9 anos.

A demora de três anos entre ter sido encontrado e ser restituído à sua família deveu-se a questões burocráticas e diplomáticas, sendo desprezadas as várias vulnerabilidades que envolviam o caso: uma criança, negra, sozinha, estrangeira, sem falar português, vinda do país mais miserável da América Latina e assolado por um terremoto. Nenhum desses fatores foi suficiente para que 0 atendimento do adolescente fosse resolvido rapidamente. O caso é emblemático

\footnotetext{
${ }^{42}$ Notícias divulgadas pelo programa dominical “Fantástico", da Rede Globo, e disponível em http://g1.globo.com/fantastico/noticia/2012/11/apos-nove-anos-haitiano-vitima-do-trafico-de-pessoasreencontra-mae.html; e em http://g1.globo.com/sao-paulo/noticia/2011/04/familia-e-vitima-de-traficode-pessoas-e-garoto-do-haiti-vem-parar-no-brasil.html, acesso em 05/11/2013.
} 
para mostrar como um crime transnacional necessita ter um atendimento transnacional, o que mostra mais uma dificuldade para o enfrentamento ao tráfico.

Para alguns entrevistados, a atuação dos agentes públicos e dos profissionais do direito podem ser vetores de violação de direitos. É o que pudemos verificar no caso acima: seja por parte do Brasil, seja por parte da Guiana Francesa, sérias omissões ampliaram as violações ao adolescente, que só foi identificado como vítima de tráfico de pessoas em razão do olhar atento de um juiz. O fato reforça a importância em sensibilizar-se os agentes do estado que lidam na sua rotina diária com varias violações e é fundamental que tenham um olhar atento e treinado para identificar no não usual, a ocorrência de tráfico de pessoas. Uma criança tida como perdida, na verdade era vítima de tráfico de pessoas.

As várias vulnerabilidades apontadas tornam o sujeito uma vítima em potencial. Mais uma vez é necessário que se aponte a necessidade da formação de profissionais que sejam sensíveis a uma realidade muito distante da sua realidade pessoal. Invisibilidade, discriminação e exclusão afastam os sujeitos da proteção jurídica e os desconsideram como titulares das políticas públicas. Para P2,

a partir do momento em que eles invisibilizam, discriminam, excluem estes sujeitos, eles estão legitimando a exclusão destes sujeitos enquanto destinatários destas políticas. (P2)

E em outro momento, o mesmo entrevistado ressalta como a atuação dos juízes pode ser pautada por valores e conceitos pré-formados, que acabam por negar dignidade aos indivíduos:

Veja, aqui em SP nós temos algumas sentenças proferidas por juízes criminais quando nestes episódios de quadrilhas de Tráfico de Pessoas que aliciam e exploram mão de obra boliviana. (...) uma sentença de uma juíza da vara criminal, que a juíza dizia, em síntese que ela não reconhecia aquela prática como Tráfico Humano porque na perspectiva dela, juíza, o fato daquelas pessoas, apesar de estarem sujeitas àquelas condições, era um fator de mobilidade social que elas estavam em condição muito melhor à que se encontravam em seus países de origem. (...) Quer dizer, então as profissionais do sexo, os transgêneros e os 
travestis, todos eles, os imigrantes ilegais, os negros, as negras vão continuar sendo nada e isso porque, é como se alguém estivesse legitimando: "não, vocês podem continuar sendo vítimas, podem continuar a sendo traficados, porque nós não reconhecemos vocês como vítimas, vocês não são nada, você não é nem sujeito". (P2)

O descaso, a desqualificação e o afastamento da vítima da sua condição de sujeito de direitos mostra-se perversa. Junto a isso, o viés da moralidade pública ainda perpassa o olhar sobre a vítima, o que pode ser verificado por Castilho (2008), ao analisar decisões judiciais proferidas em casos de tráfico de mulheres. O olhar dos juízes, a maneira como compreendem réus e vítimas fica evidenciado nas sentenças, que acabam por reproduzir preconceitos e valores socialmente construídos. É o que se pode verificar quando se observa que, embora o trabalho sexual não seja tipificado como crime, a estigmatização que as mulheres trabalhadoras do sexo sofrem assemelha-se ao tratamento dado a delinquentes. Conforme Juliano (2005) "Assim se situa uma opção laboral que não implica em delito, no mesmo campo da estigmatização que a sociedade reserva para delinquentes e pessoas afetadas pelas drogadição" (p. 83 - tradução livre) ${ }^{43}$.

Em sua fala, P7 reforça essa ideia do afastamento e da estigmatização:

A gente teve um processo criminal que pedimos a indenização da vítima e o juiz falou que eles já iam receber indenização trabalhista e que além disso não dava para fazer o cálculo e por isso ele não ia dar nada. É um juiz que não vê que tem uma pessoa ali. Não entende que quem tá ali é da espécie humana, que ele poderia estar do outro lado. (P7)

As falas acima são emblemáticas para ilustrar o afastamento das práticas dos profissionais do direito dos anseios pela proteção da dignidade humana. É o Estado revitimizando os sujeitos, reproduzindo exclusão. A falta de um olhar atento às violências que chegam de alguma forma aos órgãos oficiais pode ser um fator que favorece o tráfico de seres humanos. Quando um indivíduo, vítima

\footnotetext{
${ }^{43}$ Texto original: Así se sitúa una opción laboral que no implica delito, en el mismo campo de estigmatización que la sociedad reserva para delincuentes y personas afectadas por la drogadicción"
} 
de violência é ignorado pelo poder público, ele pode estar sendo jogado na rede de aliciamento. É o que se conclui da fala de P1:

(...) a coisa mais comum do mundo é no dia a dia de um promotor no atendimento ao público baixar alguém que foi vítima de violência. Se ele encontrar um não lá, você estará devolvendo ele pro mundo dizendo o seguinte: "Meu, se vira", nesse "se vira", esse camarada pode facilmente entrar numa rota dessas qualquer. (P1)

Mas, se por um lado a atuação dos profissionais jurídicos pode negar direitos, por outro, em via transversa, os profissionais do direito podem ser importantes reprodutores de valores e formadores de opinião. É o que se infere da fala do mesmo P7

Pensando nas instituições que compõem oficialmente 0 sistema jurídico brasileiro, que seria MP, magistratura e Defensoria, teríamos que incluir os advogados, os delegados de polícia, que eu até vejo mais com um perfil de executivo, mas estão dentro do sistema de justiça. Acho que é essencial, é onde poderia mudar muita coisa, se esse sistema todo realmente visse a importância da atuação real e se sensibilizasse e decidisse atuar nos três eixos. Porque dá para atuar nos três eixos, não é só a questão do crime, de julgar o processo criminal e acabou. É toda uma formação, são formadores e opinião, podem fazer campanhas de prevenção, a questão da visibilidade da vítima. (P7)

Segundo os entrevistados, a capacitação pode consertar percepções equivocadas, que se reproduzem nas práticas dos agentes públicos e dos profissionais do direito. A criminalização da vítima acaba sendo uma das consequências dessas percepções e isso pode aparecer tanto no trato com a exploração sexual quando no trato com a imigração irregular. É o que sugere a fala de P3, em dois momentos distintos

Eu não tenho, por exemplo, a resposta, mas onde se conserta esta percepção de que a vítima não é objeto de investigação. Onde se conserta isso? É com capacitação, com palestras, é dessa forma. Senão o olhar tradicional da polícia que sempre foi de analisar a prostituição como desordem urbana, o seu olhar é repressivo, para alguns dá a impressão de que está criminalizando a vítima. (P3) 
Dados recentes sobre casos de tráfico de pessoas que chegaram ao conhecimento do Núcleo de Enfrentamento ao Tráfico de Pessoas do Estado de São Paulo podem ser o sinal da importância da capacitação. Tendo-se em mente que a política no estado de São Paulo ganha força a partir de 2009, fazendo cumprir o I Plano Nacional de Enfretamento ao Tráfico de Pessoas inicia diversas capacitações no estado, inicia palestras de conscientização. Os dados apontam que houve um aumento significativo de casos notificados a partir de 2011. Uma das causas deste substancial aumento pode estar relacionado a maior sensibilização do olhar dos profissionais envolvidos nas redes de atendimento das políticas públicas (saúde, assistência social, segurança pública), bem como dos profissionais do direito. É inegável que a capacitação sobre um tema, até então pouco conhecido, leva a um aumento da percepção sobre os casos.

A sensibilização da população também é fator importante, por permitir ao cidadão entender que algumas práticas até então tidas como normais, passam a ser vinculadas a violação de direitos proporcionadas pelo tráfico de pessoas. Esta sensibilização certamente foi provocada pela novela Salve Jorge, da Rede Globo, de autoria de Gloria Perez, que tratou do tema e teve um importante papel na divulgação das vulnerabilidades que favorecem o tráfico de pessoas, bem como serviu de alerta para a população.

Outro ponto que permite uma reflexão sobre a atuação dos profissionais do Direito na promoção dos Direitos Humanos são as falas sobre a burocracia, as metas e a definição rígida de papéis. Por um lado, os direitos humanos são tidos como valor e diretriz de atuação, como se infere da fala de P1

Eu acho que a questão dos Direitos Humanos, eu vejo isso onde eu testemunhei de maneira muito mais direta que é na minha vida institucional, eu não tenho a menor dúvida de que a proteção e defesa dos Direitos Humanos ela é algo que, mais do que se traduzir numa diretriz de atuação, ela é um valor hoje absolutamente incorporada à atuação do Ministério Público. Ministério Público entendido como instituição para proteção e defesa dos Direitos Humanos. Eu vejo o Ministério Público como mais um dos instrumentos de promoção e defesa dos $\mathrm{DH}$. (P1) 
Por outro lado, uma questão que se impõe é como incorporar a atuação cuidadosa em Direitos Humanos numa prática diária cheia de prazos a cumprir, metas a atingir, definições precisas de atribuições. Esta também é uma reflexão colocada por P6

A exigência que se coloca para o promotor, é uma exigência pesada. Qual é a tendência: você abandona o que vai resolver o problema sistêmico, e faz o varejo obrigatório. Aí a gente tem duas maneiras de resolver: ou mexer no obrigatório, desobrigar as várias coisas, ou aumentar a estrutura de funcionário, estrutura de auxiliar, estagiários, toda estrutura de você fazer a comunicação, e ainda assim você vai enfrentar tudo isso, mas você vai mexer numa cultura, numa pessoa que foi formada para mexer com processo, não pra mexer com investigação. Alguns vão lá, com a cara e a coragem, igual Dom Quixote, com a espada dele. Existe um problema estrutural que vai ser mexido. Por mais vontade que a procuradoria geral tenha, tem a independência funcional. E se eu acho que eu não tenho que fazer isso? Eu tenho a minha independência e a minha obrigação é fazer $X$, aquilo lá é para além da sua obrigação legal. É uma obrigação com o sistema. (P6)

As falas procuram atribuir a dificuldade na promoção dos direitos humanos à chamada cultura cartorária, da burocracia e do encerramento de casos. Mais uma vez o cumprimento de metas aparece como um limitador de um atendimento atento às peculiaridades inerentes aos Direitos Humanos. É necessário que o respeito às políticas de direitos humanos não seja visto - reafirmamos isso - pelo viés da boa-vontade, pela ótica do "se sobrar tempo", se for possível. Não se pode aceitar que a produtividade justifique o descaso.

A fala de P3 permite uma reflexão entre a especialização, a formação, a capacitação, a sensibilidade ao tema:

Você tem hoje coisas setorizadas, estas delegacias de proteção às testemunhas, as delegacias de defesa da mulher que lidam com o tema, que é óbvio, violência e tal, adolescentes, idoso, tem umas especializadas nestes assuntos. Agora a massa da polícia, a polícia territorial lida com as ocorrências de massa, o máximo que se pode ter é respeito, é um ou outro que vai ter a preocupação de trabalhar Direitos Humanos num plantão com 500 pessoas sendo atendidas, não dá tempo. É por amostragem. Já as especializadas não, são especializadas nestas questões de 
Direitos Humanos. A pergunta é: as pessoas que trabalham nestas especializadas têm vocação para tanto? (...) tem um que de burocracia, de encerrar caso, mais um. Caso encerrado! No atendimento o delegado vai na técnica: já sei que tenho que mandar fazer exame de corpo delito, manda pro Forum, acabou, tchau. Não tenho tempo de ficar perguntando: porque você brigou? Você tem uma casa para ir hoje, quer que te ajude? Seria papel de especializada, mas na especializada, nem sempre tem delegados com perfil. (P3)

O perfil para trabalhar com Direitos Humanos aparece novamente, misturado à reflexão sobre a dinâmica de atendimentos. Conciliar um atendimento especializado, atento às peculiaridades de cada caso (infância, violência doméstica, tráfico de pessoas...) com um profissional que tenha um perfil adequado para enxergar suas vicissitudes é tarefa complicada. É necessário que à técnica se una a afinidade com o tema. Técnica se adquire em capacitação, treinamento, estudo. Afinidade é construída a partir da sensibilização para lidar com a diferença, comprometimento com a dignidade humana e respeito aos direitos humanos. Mas, como formar para o respeito aos direitos humanos?

Temos falado nestas linhas sobre a importância de uma formação profissional voltada aos direitos humanos. Mas é preciso mais. A educação em direitos humanos é política pública fundamental para a consecução de uma sociedade justa e solidária. O Plano Mundial de Ação para a Educação em Direitos Humanos é resultado do Congresso Internacional sobre Educação em prol dos Direitos Humanos e da Democracia, realizado em 1993. O Plano Mundial foi elaborado no sentido de "promover, estimular e orientar compromissos em prol da educação em defesa da paz, da democracia, da tolerância e do respeito à dignidade da pessoa humana" (ZENAIDE, 2007, p. 16).

Quando o Estado brasileiro assume os direitos humanos como princípio, todas as políticas públicas devem direcionar-se a este propósito, baseadas na perspectiva da construção de uma sociedade onde a promoção da igualdade de oportunidades e da equidade, o respeito à diversidade e a consolidação de uma cultura democrática e cidadã sejam o norte. Deste modo, promover educação de qualidade para todos, entendida como direito humano essencial, é dever do Estado, com fundamental apoio da sociedade civil. Esta formação em e para os 
direitos humanos talvez seja o primeiro passo para construir cidadãosprofissionais comprometidos com a sociedade em que está inserido.

“Em tempos difíceis e conturbados por inúmeros conflitos, nada mais urgente e necessário que educar em direitos humanos, tarefa indispensável para a defesa, o respeito, a promoção e a valorização desses direitos" (BRASIL, 2007, p. 21). Num país marcado por desigualdades e exclusão econômica, social, étnico-racial, cultural e ambiental, decorrente de um modelo de Estado em que muitas políticas públicas deixam em segundo plano estes direitos, a educação para os Direitos Humanos aparece como, se não a única, uma das únicas saídas baseadas no protagonismo dos cidadãos, para uma luta autônoma por dignidade e justiça social.

Outra questão que aparece é a importância de um fluxo de atendimento que conheça o problema a ser enfrentado (no caso, o tráfico de pessoas), o que dificultaria um diagnóstico equivocado. Deste modo, a capacitação almejada deverá ser feita de maneira bastante ampla, para atingir o maior número possível de agentes. É o que encontramos na fala de P5.

Como é que vai chegar ao Judiciário: você tem vários filtros. Você tem o filtro da polícia, o filtro do Ministério Público para depois chegar no filtro do judiciário. $\mathrm{O}$ que a vida me ensina é assim: se desde o início você direcionar errado, a possibilidade de chegar até o fim errado é muito grande. Então, o primeiro filtro tem que ser ajustado para estruturar o fluxo, senão não chega no judiciário nunca. Se o meu técnico não tiver capacidade para saber o que é o tráfico, não adianta eu saber, porque é ele que vai ter o contato, ele que vai fazer o relatório e ele passa a impressão dele prá mim, escrito. (...) Se você não prepara o técnico para ver, ele vai filtrando. Com o tráfico é a mesma coisa. Se você não sensibiliza quem vai fazer 0 atendimento, pegar 0 depoimento na polícia, no caso da Delegacia de Homicídio e Proteção à Pessoa (DHPP), você não vai identificar. $\mathrm{Na}$ prostituição, a delegacia responsável para casos de prostituição, se lá os investigadores de polícia não identificarem que é tráfico, nunca vai chegar no Judiciário. (P5)

Diante de tudo que foi dito, uma questão apareceu em algumas das entrevistas: faz alguma diferença, a forma como os profissionais jurídicos veem a 
política, veem a vítima, veem as articulações, faz alguma diferença para a efetividade dessas políticas? Duas posições divergentes apareceram.

Há entrevistados que entendem que os profissionais do direito têm papel significativo na consecução de políticas públicas, como observamos na fala de P7:

Pensando nas instituições que compõem oficialmente 0 sistema jurídico brasileiro, que seria Ministério Público, Magistratura e Defensoria, teríamos que incluir os Advogados, os Delegados de Polícia, que eu até vejo mais com um perfil de executivo, mas estão dentro do sistema de justiça. Acho que é essencial, é onde poderia mudar muita coisa, se esse sistema todo realmente visse a importância da atuação real e se sensibilizasse e decidisse atuar nos três eixos. Porque dá para atuar nos três eixos, não é só a questão do crime, de julgar o processo criminal e acabou. É toda uma formação, são formadores e opinião, podem fazer campanhas de prevenção, a questão da visibilidade da vítima. (...) Então, o papel dos profissionais do direito é essencial, eu acho até que eu dividiria em 50\%. 50\% do executivo, que faz a política pública e os outros $50 \%$ do direito. Um complementa o outro. Um sem o outro não consegue fazer um sistema de enfrentamento ao tráfico. (...) Os profissionais do direito são convidados a participar da política. Pode ser que nenhum deles participe, porque é convite. Pode ser que naquele momento, por qualquer razão que seja, ou por falta de verba, ou por falta de interesse, ou por falta de qualquer coisa, não vá. Eu acredito que pegue muito mal, que estas instituições não se façam representar. (P7)

Posição diversa podemos observar na fala de P8

Fazer diferença faz, mas isso de fazer diferença para que haja um câmbio efetivo? Não. Fazer diferença faz, porque a partir do momento que este agente público, inserido nessa estrutura seja do judiciário, seja da polícia, seja de onde for, tem essa sensibilidade mais aguçada para essa situação de vulnerabilidade social, o cara vai correr atrás de resolver problema, vai querer estudar, vai querer saber, vai querer ver a dinâmica, vai querer acompanhar diligências, saber como são as coisas. (...) Isso vai fazer diferença? Vai, para aquele agente que procurou. Vai para aquele cara que foi preso, de uma maneira pontual. Efetivamente, de forma ampla, vai fazer diferença? Não. (...) Não tenho crença na forma jurídica como algo necessário ou importante para 
promover mudanças sociais efetivas, revolucionárias, alterações dentro dessas dinâmicas. (...) O direito vai continuar cumprindo a tarefa dele enquanto for proveitoso ter gente trabalhando como escravo, vai continuar cumprindo a tarefa, as instituições jurídicas vão continuar cumprindo suas tarefas de cegas a estes sujeitos, enquanto elas estiverem cumprindo uma tarefa essencial para o capital. (...) Pode ter um cara ou outro que é mais sensível, que corra atrás, esses caras vão ser exceção. A própria política não propicia isso, o ensino jurídico não proporciona isso, isso vai vir de um caráter subjetivo daquele indivíduo ali, que tenha maior sensibilidade.(...) Gera efeitos, com toda certeza. Não dá para negar. Mas ela gera efeito de forma isolada. (...) Eu acho que o papel que eu cumpro enquanto profissional, ele é pontual, ele é necessário, porque se não foi feito, ninguém faz e é a barbárie. Tem que ser cumprido? Tem que ser cumprido, cada vez por mais profissionais. Mas isso não é o suficiente. O problema é estrutural e tem que ser tratado de forma estrutural. Então ele não pode ser pensado como ações isoladas. (P8) 


\section{2 - Categoria 2 - Vulnerabilidades: Violências como causa e como consequências do tráfico de pessoas.}

O Tráfico de Pessoas está envolto em violações de Direitos. Seja a violência que vulnera, que fragiliza, que expõe os indivíduos e os deixam a mercê da exploração, seja a violação provocada pelo tráfico em si, pautada na exploração de seres humanos, uma violência que coisifica, que diminui, que aniquila a dignidade. A violência aparece como causa e como consequência do tráfico de pessoas. É um círculo vicioso que vitimiza e revitimiza a pessoa e coloca em xeque a dignidade humana.

As violações que permeiam o tráfico foram tema constante nas entrevistas. Na categoria "Vulnerabilidades: Violências como causa e como consequências do Tráfico de Pessoas", foram ressaltados os cenários pré e pós tráfico humano: quais vulnerabilidades levam os sujeitos a se tornarem vítimas desta prática e que violências decorrem do tráfico de pessoas. No caso das violências decorrentes do tráfico de pessoas, o que foi discutido aqui restringiu-se às omissões públicas que vulneram o indivíduo.

A vontade de uma vida melhor aparece como elemento que leva a vítima à exploração e muitas vezes essa vontade está atrelada à vulnerabilidade da vítima, que pode ser observada tanto na origem quanto no destino. É o que se infere da fala de P6.

Eu acho que o que move sempre, é o desejo de uma vida melhor, ou de uma vida diferente, ou da possibilidade cultural, uma possibilidade de trabalho, ou de uma vivência diferente. É sempre o desejo daquilo... do jardim do outro mais atraente, é o desejo de uma vida melhor. Porque as pessoas, a gente vê, as populações que saem e são explorados são pessoas de alta vulnerabilidade. Em situação ... a gente pensa na vulnerabilidade na origem. Qual a diferença da vulnerabilidade na origem e a vulnerabilidade no destino? É que no destino a pessoa perdeu a liberdade. (P6) 
A diferença da vulnerabilidade de origem e destino foi trazida por Leal, Teresi e Duarte (2013), em estudo feito com nove mulheres que migraram do Brasil (Estado de Goiás) para a Europa (Portugal e Espanha). Neste estudo, em entrevistas com as mulheres e suas famílias, a vulnerabilidade de origem aparece retratada principalmente nas condições socioeconômicas. Pobreza, trabalho precoce (infantil), baixa remuneração, longas jornadas de trabalho, são apontados como condições que as levaram a aceitarem ir para a Europa como possibilidade de mobilidade social.

A vulnerabilidade de destino começa logo na chegada. Algumas se dizem enganadas com falsas promessas sobre qual tipo de trabalho fariam, sobre a facilidade da vida na Europa, sobre a possibilidade de ficarem ricas. Chegam vinculadas a uma dívida que as aprisiona, que cresce a cada dia, são constantemente vigiadas, tem seus documentos retidos, tem que realizar muitos programas na mesma noite, vivem em condições insalubres, exposição a doenças sexualmente transmissíveis, jornadas extensas de trabalho, uso de drogas, violências físicas e psicológicas.

Como o estudo em questão acompanhou algumas das mulheres em sua volta para o Brasil, é interessante observar que algumas delas não se adaptaram a voltar a viver no Brasil. Relataram falta de acesso a serviços de saúde e assistência social. Pela leitura dos dados, podemos inferir que $o$ atendimento às vítimas não tem cumprido o seu propósito maior de garantir a elas um retorno digno à origem, bem como não tem sido priorizado pelas políticas públicas, uma vez que algumas relatam que a ajuda que tiveram foi através de organizações não governamentais.

A vulnerabilidade das vítimas pode ser verificada em qualquer que seja a forma em que se dá o tráfico de pessoas. Alguns profissionais entendem que não se deve fazer distinção entre tráfico para fins de exploração sexual, de tráfico para fins de exploração do trabalho escravo, de tráfico de órgãos. Para P1 o mais importante é identificar que existem as vítimas de exploração ilegal e isso é que deve ser observado e que o estado de São Paulo é ponto de chegada e de partida do tráfico, mas não entende que seja o local do aliciamento das vítimas. 
Mais do que rotular, melhor do que rotular e eu acho que qualquer tentativa de rotulação ela corre o risco de ser leviana e equivocada, mas o que eu não posso fechar os olhos é que existe situação de exploração ilegal no estado de São Paulo, aqui é para onde tudo converge. (...) A convergência da exploração é para o estado de São Paulo, agora eu não vejo a questão do aliciamento e veja, eu vejo de uma maneira muito clara o perfil, a vocação da cidade de São Paulo, do estado de São Paulo, da cidade para serviço e do estado para o cultivo da cana de açúcar e a cidade de São Paulo para a indústria da construção civil. São dois, mas é um olhar de preocupação sobre a exploração ilegal em si já configurada. É claro que toda vez que você identifica é dali pra trás, de onde veio, como veio, etc., mas veja, a par disto qualquer tentativa de qualificação ou de rotulação de tráfico disso ou de tráfico daquilo acho muito temerário e corre o risco de ser, de se levar a conclusões precipitadas. (P1)

A distinção entre exploração do trabalho e exploração sexual também se perde diante da constatação de que a vítima é explorada economicamente e seja para qual finalidade for, a vítima é uma trabalhadora. É o que se infere da fala de P8

Pra mim, embora haja esta distinção no protocolo de
Palermo, as pessoas lidem com isso tecnicamente, distinção
entre trabalho escravo e tráfico para exploração sexual e
tráfico de órgãos, as pessoas façam essa distinção, eu não
consigo distanciar a questão da exploração do trabalho
escravo. Porque a mulher que é explorada sexualmente e
está numa situação de exploração efetiva do seu corpo, ela
está sendo explorada economicamente e a exploração
econômica não é nada mais que uma trabalhadora.
Independentemente ela é vítima, ela é trabalhadora, ela está
numa condição enquanto trabalhadora, de explorada
economicamente. Então, eu faço e penso uma identidade
dessas situações, porque o explorador da costura ou o
explorador forçando a pessoa a fazer um programa ou
alguma coisa do gênero, tem uma relação de identidade
muito próximas. (P8)

Por mais que se pretenda uniformizar a exploração pelo viés do trabalho, é necessário que estabeleçamos uma reflexão pela perspectiva de gênero. Não é possível desprezar o fato de que existem vulnerabilidades às quais as mulheres estão mais suscetíveis. Para Damásio de Jesus (2003) aspectos culturais presentes na discriminação de gênero levam à desvalorização das mulheres, 
muitas vezes tratadas como mercadoria que tem preço no mercado do sexo. A imigração e o tráfico muitas vezes aparecem como opção frente a uma vida de negação de direitos e de identidade.

Dados do Relatório de Desenvolvimento Humano 2010, das Nações Unidas (ONU, 2010), revelam que, com grande frequência, as mulheres e jovens do sexo feminino sofrem discriminação na saúde, na educação e no mercado de trabalho, que leva a repercussões negativas sobre as suas liberdades. Estas vulnerabilidades levaram à criação do Índice de Desigualdade de Gênero - IDG, que inclui o sucesso educativo, a participação econômica e política e os problemas de saúde especificamente femininos. A criação do IDG reforça a certeza de que as mulheres encontram-se em situação de maior vulnerabilidade.

As mulheres, as crianças, os travestis, frágeis como todos os indivíduos assujeitados pela dinâmica do mercado a serem explorados nas relações de trabalho, são também suscetíveis à exploração sexual. A percepção da mulher e do travesti que são explorados sexualmente serem vistos como mercadoria é trazida por Juliano (2005), Pascual (2007), Agnoleti (2008), Chejter (2010). A coisificação do humano pela exploração econômica é ressaltada por P6, quando reflete sobre ser o indivíduo uma mercadoria reutilizável

As pesquisas que eu vi lá na Europa, os autores que eu vi escrevendo, eles colocam o seguinte: o tráfico de pessoas, quantitativamente, é a maior violação de $\mathrm{DH}$ que se tem na atualidade. Eles colocam por que isso? Tem várias razões: primeiro: por exemplo, quando você apreende uma droga, a droga é apreendida e teoricamente incinerada, ela não volta para o mercado. A pessoa não. Você tira ela, mas se você não acolhe, não dá uma condição prá ela, ela volta pro mercado. Então ela é uma mercadoria reutilizável. (P4)

Para P4, a vulnerabilidade coisifica o ser humano.

Eu acho que é por isso que o aliciador consegue ter um pouco mais, além da repressão violenta, além das ameaças e tal, por conta dessa fragilidade, ele consegue ter as garras mais fixas nessas pessoas por conta dessa vulnerabilidade mesmo. Eu diria que a gente tem a ideia de vulnerabilidade desses segmentos e quando a gente fala de Tráfico de Pessoas a gente nem considera mais o segmento como ser humano, a gente já considera ele como objeto e aí o objeto 
gera lucro, no comercio ele vai gerar lucro, e aí você tem o aliciador e o cara que consome, tratando aquilo não mais como ser humano vulnerável. Se a gente tem crianças, idosos como seres humanos vulneráveis e que merecem proteção, no caso do tráfico esta vulnerabilidade nem existe mais como ser humano, é coisa. (P4)

O caráter econômico do tráfico de pessoas apareceu na fala de P7, também pontuando o fato da vítima ser tratada como mercadoria.

Uma das coisas que eu mais me lembro das minhas de tráfico de pessoa lá no mestrado que eu fiz, foi essa visão econômica do tráfico de pessoa. A gente tem essa visão do social, do coitadinho, vem prá cá enganado, os meios utilizados, mas a gente esquece um pouco essa questão do objetivo do tráfico. Porque a pessoa pode vir, ela pode ter todos os verbos do protocolo, mas se o objetivo não for explorar no final, não é tráfico. Pode ser qualquer outra coisa, pode ser o contrabando de migrantes e tantas outras questões que envolvem, não só criminais. Mas esta questão que envolve a exploração, esse interesse econômico de tratar a pessoa como mercadoria é que é o foco. (P7)

A análise do tráfico pelo enfoque econômico parece ser inevitável. Se por um lado as motivações e fragilidades das vítimas são apontadas como favorecedoras da exploração em razão das vulnerabilidades, não se pode olvidar que maiores do que as fragilidades das vítimas são a ambição de lucros de determinados grupos, que exploram a vida humana como mercadoria. Nessa busca pelo enriquecimento e pelo lucro, o que se observa é que o poder econômico atua dos dois lados: de um lado torna a vítima vulnerável e por isso suscetível à exploração; de outro, mobiliza um mercado que enriquece os aliciadores e exploradores que veem no tráfico de pessoas um ótimo negócio.

Para acabar com a exploração advinda do tráfico de pessoas é fundamental que os esforços sejam no sentido tanto de garantir direitos aos grupos vulneráveis e excluídos da proteção social quanto no sentido de evitar que o tráfico continue sendo um negócio rentável. Ação nesse sentido pode ser observada na Promulgação da Lei 14.946, de 28/01/2013 (SÃO PAULO, 2013), que cassa a inscrição no cadastro de contribuintes do Imposto sobre Operações Relativas à Circulação de Mercadorias e sobre Prestações de Serviços de Transporte Interestadual e Intermunicipal e de Comunicação - ICMS de qualquer 
empresa que faça uso direto ou indireto de trabalho escravo ou em condições análogas. Apesar de não ser uma lei que puna especificamente o tráfico de pessoas, entendemos que é importante passo para que esta prática seja coibida, uma vez que atinge diretamente o elo final da exploração.

No ano de 2011, o Estado de São Paulo, fazendo cumprir o disposto na Política Nacional de Erradicação do Trabalho Escravo instituiu, através do Decreto 57.368, de 26 de setembro de 2011 (SÃO PAULO, 2011), a Comissão Estadual para Erradicação do Trabalho Escravo - COETRAE/SP, vinculada à Secretaria da Justiça e Defesa da Cidadania, amplamente articulada com a Política Estadual de Enfrentamento ao Tráfico de Pessoas. A criação dessa Comissão acabou fazendo com que a Secretaria de Justiça e Defesa da Cidadania propusesse uma mudança de foco na atuação do Comitê Estadual Interinstitucional de Enfrentamento ao Tráfico de Pessoas, conforme se infere da leitura da Ata da Primeira Reunião de 2012 do referido Comitê, realizada em 13/04/2012 44 :

\begin{abstract}
Secretaria da Justiça e da Defesa da Cidadania: apresenta sugestão, que o comitê trate da temática de tráfico de pessoas, priorizando a exploração sexual, principalmente de crianças e adolescentes, e que, frente a criação da Comissão para Erradicação do Trabalho Escravo, pudéssemos realizar uma divisão de trabalhos, tendo o tema trabalho escravo enfoque voltado ao COETRAE, otimizando propostas nos dois grupos. O Comitê Estadual poderia trabalhar com a questão de tráfico de pessoas para exploração sexual, exploração sexual infantil, de transexuais, infância e juventude e tráfico de órgãos. (Diário Oficial de São Paulo, 04/12/2012, p. 15)
\end{abstract}

Uma atenção sobre os trabalhadores bolivianos aparece na fala de P8, que analisa a forma como os bolivianos chegam ao Brasil, para ganhar quanto e sob quais condições:

Os bolivianos chegam ao Brasil por meio de agenciamento, tem agências lá que falam que o cara vai vir prá cá para trabalhar na costura, ou no trabalho doméstico. Falam que vão pagar salário em dólar, em patamares altos para uma remuneração de lá, 700 dólares, 900 dólares, que irão tirar

\footnotetext{
${ }^{44}$ Publicada no Diário Oficial do Estado, Poder Executivo, Seção I, pág. 15, edição 226.
} 
por mês. Lá os caras não tiram isso, normalmente veem endividados, veem em rotas loucas, gigantescas para passar em locais onde a PF e a receita não tem tanto controle na fronteira, acabam vindo nessas condições. lludidos mesmos. Acham que vão trabalhar e vão conseguir levar a grana prá lá, mas não conseguem. Ou conseguem. Tem algumas situações que nem receber os caras conseguem. Mas, tem algumas situações que conseguem, mas a que custo. Vai ganhar 700 dólares por mês, sim, mas vai trabalhar das 9 da manhã às 11 da noite. De segunda a sábado. (P8)

A fala do entrevistado reforça o caráter econômico da exploração, as condições precárias em que vivem os bolivianos na origem. A Bolívia é um dos países com menor índice de desenvolvimento humano da América Latina, tem alto índice de analfabetismo e $70 \%$ da sua população está abaixo da linha da pobreza (TELES, 2007). As condições de vida dos bolivianos em seu país de origem levam a preferirem a exploração do trabalho no Brasil ao desemprego na Bolívia (BASSEGUIO; FREIRE, 2005, p. 117).

A população de bolivianos em São Paulo tem aumentado muito nos últimos anos. $40 \%$ dessa população vivem em situação irregular (BASSEGUIO; FREIRE, 2005), muitos deles temem denunciar as violações, por terem medo de represálias e também medo da polícia. Mesmo após pagarem suas dívidas os trabalhadores continuam presos à burocracia e ao descaso que os mantém a margem dos direitos. Segundo P6, a população de bolivianos em São Paulo é invisível, sem direitos, ignorada pelo Estado.

E um dado que não é oficial e que me foi passado é que há uma população de 450 mil bolivianos em SP, na capital. E você olha, no Bom Retino, no Braz, aquelas oficinas, uma atrás da outra, e me volta o mesmo questionamento: o que, ou qual os fatores, fazem o Estado não se mobilizar, não se mobilizar nem na área criminal nem na área cível, nem no que é da competência federal e nem do que é da competência estadual e nem municipal. É uma população de pessoas invisíveis, e que solução que a gente vai propor, ou vai tentar fomentar, será que na área criminal vai resolver? E aí, a gente chegou à conclusão, que, antes de dar a opção econômica a estas pessoas, porque elas querem estar no Brasil porque na Bolívia a situação delas é pior, então antes de dar a opção econômica, você não pode sair prendendo, não pode sair agindo na esfera criminal, tomando uma 
atitude, como por exemplo, fechar as oficinas. $E$ a população, vai viver do que? (P6)

A exclusão social, conjugada com a falta de perspectiva de uma vida melhor e a baixa autoestima dos sujeitos, foram apontadas como causas frequentes da vulnerabilidade que leva ao tráfico. A ideia de que qualquer vida é melhor que a vida que se leva, nas condições em que se vive, leva as vítimas a acreditarem em engodos, em promessas, em Eldorados. Para P2,

A questão é que temos um Brasil de contrastes, nós temos vários Brasis dentro do nosso Brasil. Infelizmente, apesar desse desenvolvimento econômico, nós temos dentro do Brasil, o que o fenômeno da globalização fez com estas outras pessoas, que tem sonhos, que também estão em linhas de vulnerabilidade e exclusão social, principalmente as mulheres, as mulheres vítimas de violência, elas são um "mercado interessante" para estas redes de tráfico e aliciamento, porque elas estão com baixa auto estima, estão numa situação de vulnerabilidade porque elas estão muitas vezes fora da suas casas, sem alternativa econômica . (...) Ela não vai pensar duas vezes. Então veja, você tem uma juventude sem perspectivas, sem objetivos de vida, em regiões carentes em que a única presença estatal é muitas vezes a viatura da PM, você acha que estas jovens e jovens, em sua maioria negros e negras, eles não vão se deixar seduzir por uma proposta de uma rede de aliciamento? Claro que vão! Eles desejam também melhorar de vida, é um status que eles nunca teriam numa situação normal. (...) Então a gente precisa entender como é este público alvo, esta população que está vulnerabilizada a ponto de ser alvo fácil prá estas redes. (P2)

Segundo as Regras de Brasília (Conferência Judicial Ibero-Americana, 2008) sobre acesso à Justiça das pessoas em condições de vulnerabilidade

Consideram-se em condição de vulnerabilidade aquelas pessoas que, por razão da sua idade, gênero, estado físico ou mental, ou por circunstâncias sociais, económicas, étnicas e/ou culturais, encontram especiais dificuldades em exercitar com plenitude perante o sistema de justiça os direitos reconhecidos pelo ordenamento jurídico (COFERÊNCIA JUDICIAL IBERO-AMEERICANA, 2008, p. 5). 
A relação da vulnerabilidade social com a falta de acesso ou o acesso precário ao sistema de Justiça ${ }^{45}$ nos leva a pensar sobre o papel do Estado na promoção de direitos. Não basta que se definam direitos se não houver mecanismos efetivos para a sua concretização de modo a garantir a sua tutela, sobretudo se levarmos em consideração que as pessoas em condição de vulnerabilidade encontram obstáculos muito mais incisivos para o exercício dos direitos supostamente garantidos. Auxílio importante (e talvez o único) para diminuir as vulnerabilidades e reduzir as desigualdades cabe ao sistema de justiça.

Dentre as causas de vulnerabilidade apontadas no documento temos a idade, o pertencimento a grupos classificados como minorias, a vitimização, a migração e o deslocamento interno, a pobreza, o gênero. Todas essas características são encontradas nas pessoas que são vítimas de tráfico de pessoas, o que demonstra como a vulnerabilidade social apresenta-se como fator importante a levar as pessoas para as redes de aliciamento.

A desigualdade social aparece nas entrevistas e, colocada por P3 como seletividade, é apontada como fator de vulnerabilidade. Para ele

Se você perguntar para $100 \%$ dessas vítimas, porque você foi prá lá: é lugar comum: quero melhor condição de vida, quero comprar um carro, quero isso, aquilo, quero ter um tênis. A causa do fenômeno traficância está ali. Você tem alguém querendo sair do país mas não tem documento, aí entra o tráfico de migrantes e nosso país não tem nenhum tipo penal pra isso. (...) Num país, em que você tem a seletividade pra nascer, seletividade para entrar no sistema educacional, você tem seletividade para sair do sistema educacional. É uma sociedade de peneira, você vai peneirando... (P3)

\footnotetext{
${ }^{45}$ As Regras de Brasília (Conferência Judicial Ibero-Americana, 2008) sobre acesso à Justiça das Pessoas em condições de vulnerabilidade define como a atores do sistema de justiça: a) Os responsáveis pela concepção, implementação e avaliação de políticas públicas dentro do sistema judicial; b) Os Juízes, Fiscais, Defensores Públicos, Procuradores e demais servidores que laborem no sistema de Administração de Justiça em conformidade com a legislação interna de cada país; c) Os Advogados e outros profissionais do Direito, assim como os Colégios e Agrupamentos de Advogados; d) As pessoas que desempenham as suas funções nas instituições de Ombudsman (Provedoria).

e) Polícias e serviços penais. f) E, com carácter geral, todos os operadores do sistema judicial e quem intervém de uma ou de outra forma no seu funcionamento. (p. 9)
} 
É importante que se analise a vulnerabilidade por suas muitas dimensões. Como mencionado por P3, o cidadão vai sendo submetido a uma série de seleções que o colocam a parte da titularidade de direitos e por isso o torna suscetível a ser aliciado, fator favorecido por um estado omisso e por uma sociedade hierarquizada, que luta para manter privilégios. A multidimensão da vulnerabilidade social é trazida por Busso. Para ele,

A noção de vulnerabilidade é entendida como um processo multidimensional que conflui no risco ou probabilidade do indivíduo, família ou comunidade de ser ferido, lesionado ou danificado ante as mudanças ou permanência de situações externas e/ou internas. A vulnerabilidade social de sujeitos e coletivos de populações se expressa de várias formas, seja como fragilidade e desamparo ante as mudanças no ambiente, seja com o desamparo institucional do Estado que não contribui para fortalecer e nem cuida sistematicamente de seus cidadãos; como debilidade interna para enfrentar concretamente as mudanças necessárias do indivíduo ou família para aproveitar o conjunto de oportunidades que lhes são apresentadas; com insegurança permanente que paralisa, incapacita e desencoraja a possibilidade de pensar e agir sobre as estratégias futuras para alcançar melhores condições de vida (BUSSO, 2001, p. 8, em tradução livre)

O conceito nos remete à responsabilidade do Estado como agente, por omissão, das vulnerabilidades sociais. A partir do momento em que o Estado não age no sentido de fortalecer e dar poder aos cidadãos inviabiliza o protagonismo dos mesmos. Seja na saúde, seja na educação, seja no acesso à Justiça, as políticas públicas são instrumentos necessários para reduzir as desigualdades e promover a dignidade.

A seletividade apontada por P3 acaba por ser um elemento que afasta o indivíduo de oportunidades de vida e inserção social que lhe garantam, ou pelo menos não sejam impeditivas, de sua dignidade. Um dos fatores que de dificultam a promoção da dignidade são as forças de mercado cada vez mais guiadas exclusivamente pelas pressões da competitividade. É um mundo de abismos: de um lado a opulência e de outro a negativa de direitos mínimos a grande parcela da população (SEN, 2010). Essa exclusão gera, para Bauman (2007) pessoas descartáveis, para Sousa Santos (2007), não-cidadãos. 
A precarização das relações de trabalho é condição determinante das vulnerabilidades em questão. A vulnerabilidade de classes é vinculada à vulnerabilidade econômica e apontada por P8 como uma fragilidade ainda maior para os grupos que além de serem prejudicados pela precariedade econômica, são reduzidos a uma condição de sujeição política. Para o entrevistado, a consciência de classe seria um fator que reduziria a vulnerabilidade dos sujeitos. Diz:

O único referencial que a gente tem que pensar em vulnerabilidade, é a primeira, e isso a gente tem que pensar com relação a todas as vítimas, é uma questão de vulnerabilidade econômica, é uma questão de vulnerabilidade de classe que é muito acentuada. E eu digo que essas duas balizas, a econômica e a de classe elas tem que ser levadas em conta, pelo fato de, por exemplo: localidades em que tem uma organização de classe, ainda que a população seja paupérrima, seja miserável, mas que tenha uma organização de classe relativamente forte (...) Eles não são sujeitos ativos nem passivos do tráfico lá. Por existir a consciência política, eles são menos sujeitos a esse tipo de coisa. (P8)

A reflexão sobre a vulnerabilidade de classe feita por P8 prossegue. Para esse entrevistado, a vulnerabilidade econômica pode ser mitigada pela organização de classe. É o que podemos inferir da fala abaixo

(...) vamos pegar o exemplo dos bolivianos: o cara vem para cá com que? Uma promessa de vida melhor. Vou trabalhar lá e ganhar o triplo do que eu ganho aqui, vou poder comprar uma terrinha aqui depois, vou poder mandar dinheiro pros meus pais, é essa ideia que é vendida para eles. Ainda que numa situação de sujeição econômica, que é muito acentuada, isso aí não é o papo que cai fácil no ouvido de um mineiro que está lá na extração de gás, que vive numa situação pesadíssima de exploração, que poderia estar numa vida melhor, quem sabe até melhor costurando aqui, mas o cara não cai nesse papo. (P8)

A desorganização de classe é apontada por Teles (2007), como um fator que também dificulta a proteção dos bolivianos em São Paulo. Para a autora, os trabalhadores bolivianos são trocados constantemente de local de trabalho, tanto para evitar a fiscalização quanto para impedir que se organizem e se tornem fortes na luta por seus direitos. 
De qualquer modo, apesar da organização de classes ser fator importante na construção de sujeitos fortes e cientes de seus direitos, o que observamos é que a vulnerabilidade econômica sobressai e é fortemente apontada como causa da vinda de bolivianos para São Paulo. É o que se infere da fala de P4

Como os bolivianos, quando eu estouro uma oficina de costura na Estação da Luz, você encontra outra vez com eles em Santo André, ganhando 0,20, 3,00, mas é muito mais do que eles ganhariam em La Paz ou em outra cidade da Bolívia. (P4)

A questão econômica aparece novamente na reflexão de P8

Porque em muitas situações é isso: o sujeito está fragilizado economicamente, recebe uma oportunidade que vem do nada, ou de alguém conhecido, mas uma oportunidade que pra ela falta aos olhos. É essa fragilidade econômica que acaba levando a pessoa a embarcar nisso. A gente pensa em tráfico de pessoas, em mercantilização humana, poxa, são raros os casos em que são raptos, que você pega a pessoa e arrasta. Não é isso. Existe toda esta lógica de convencimento e o convencimento normalmente vem pelo aspecto econômico, tanto no caso do trabalhador que vem prá cá e vai prá outro lugar, quanto no caso da exploração sexual. (P8)

Outro fator que aparece em algumas entrevistas é a vulnerabilidade decorrente do comportamento machista. O machismo muitas vezes leva a não aceitação da diversidade sexual e é apontado como fator que vulnerabiliza o travesti que é aliciado do nordeste para São Paulo. A baixa autoestima que acompanha esta vulnerabilidade é representada também na fala de P4

Ou você encontra travestis do nordeste, muitas vezes, que, como que o pai vai admitir que o filho é um travesti, naquele lugar machista do sertão, quem vai acolhe-los lá? Nem o Estado acolhe, então ele vem pra cá, e vem com gosto. Aqui ele encontra pessoas que o protegem e encontra pessoas iguais a ele. O que eles fazem? Eles se unem. Aquele tráfico de pessoas pra eles foi o grande salvador, e a gente tá atrapalhando. $\mathrm{Ou}$, a pessoa, para ela ser de alguma forma seduzida a participar desta rede, muitas vezes ela não vai por força, ela vai por gosto, porque ela quer. A autoestima dela é tão baixa que ela não se vê como vítima, ela vê o cara como um padrinho, um cara que favorece, um cara bonzinho. (P4) 
Um dado alarmante é o crescimento da violência contra a população LGBT (Lésbicas, Gays, Bissexuais, Transexuais e Travestis) no Brasil. No Relatório Sobre Violência Homofóbica no Brasil (BRASIL, 2012), é relatado um aumento de $166,09 \%$ das denúncias e 46,6\% no aumento das violações contra homossexuais, apesar da subnotificação das violências em geral e das violências contra a população LGBT em particular.

Travestis e transexuais têm sido em grande maioria, marginalizados e vítimas de preconceitos, exclusão e abuso, que começam dentro de casa, continuam nas escolas e culminam no mercado de trabalho. Para a maioria, a prostituição é uma saída, em todos os sentidos. O preconceito tem-se mostrado alarmante em todo o país, mas os dados apontam que o crescimento maior da violência se deu nos estados do Norte e Nordeste do país. Isso talvez explique a fala de P4 acima, quando diz de um melhor acolhimento que as vítimas têm em São Paulo. Agnoleti reafirma esta tendência dos grandes centros atraírem os travestis, apontando também o fato da prostituição ser encarada como uma saída, uma "possibilidade concreta (...) de socialização e expressão de uma sexualidade feminina coerente com suas identidades e desejos" (2008, p. 2).

Nesta ânsia por uma vida melhor muitos travestis acabam sendo aliciados por redes de tráfico de pessoas, contraindo dívidas imensas relativas a gastos com passagens, alimentação, vestuário e com isso acabam tornando-se, como as mulheres, escaravos sexuais, a mercê de rufiões e cafetinas (VASCONCELOS, 2009). Teixeira (2008) aponta a necessidade das análises diferenciarem a problemática da exploração sexual da prostituição, possibilitando uma melhor reflexão sobre a posição dos travestis, os quais de um lado não se veem como vítimas, e de outro das Organizações Não Governamentais (ONGs) que atuam no combate ao tráfico e na proteção das vítimas no exterior, que enxergam toda situação como exploração.

O não reconhecimento por parte das travestis de que são/foram exploradas/traficadas cria uma situação ambivalente, ora o discurso oficial empregado pelas ONGs coloca as travestis no lugar daquelas consideradas traficadas, exploradas e, portanto, necessitam de proteção ou as deslocam para a situação de "perigosas e bandidas" ao vincular a prostituição à marginalidade 
(indocumentadas8) e à (des) ordem pública. (TEIXEIRA, 2008, p. 280)

O machismo também é apontado como um fator que favorece a exploração sexual de mulheres, como se observa na fala de P6

a gente tinha que incriminar quem compra. E sabe porque não é incriminado? Porque é a coisa mais antiga do mundo e porque na verdade os homens não vivem sem isso, e na verdade os homens que mandam no mundo. A gente vê, os homens que vão atrás da prostituição, como se fosse a coisa mais natural do mundo, pensando e falando daquelas mulheres como se fossem objetos. (...) Agora, você está vendendo porque você é vítima de um sistema, então você não incrimina a pessoa que vende, mas aquele que compra, será que ele precisava satisfazer o desejo dele daquele jeito? Precisava tanto? É um poder que se tem. É um poder que o homem exerce sobre a mulher. É o poder que o mundo masculino exerce sobre o feminino. É uma ação que transmite doença, é uma ação que engravida a mulher. (P6)

Esse poder é apontado por Teles (2007), quando analisa a vulnerabilidade das bolivianas imigrantes em São Paulo. Para a autora, as bolivianas são invisíveis por serem mantidas enclausuradas nas oficinas de costura, trabalhando mais de 16 (dezesseis) horas por dia em condições insalubres, mas sobretudo são invisíveis quando sofrem no seu dia-a-dia a violência doméstica e sexual. São invisíveis porque não reclamam, não pedem ajuda ou providência ao Estado, por medo de se tornarem ainda mais vulneráveis.

A violência doméstica e sexual que é uma luta crescente da população brasileira aparece de maneira incisiva entre as bolivianas que são ignoradas pelas políticas públicas. Para Teles, "as políticas públicas de enfrentamento ao tráfico de pessoas, em particular o de mulheres, não levam em consideração a demanda por serviços públicos provocada pelo fluxo imigratório" (TELES, 2007, p. 40). As mulheres imigrantes, seja a boliviana no Brasil, seja a brasileira na Europa, trazem em si grande parte dos fatores de vulnerabilidades que levam à exploração e negativa de direitos: são minoria, são vítimas, são migrantes, são pobres, e são mulheres. E nesse quadro, são facilmente aliciadas pelas redes de tráfico seja para o trabalho escravo, seja para o tráfico para fins de exploração sexual. 
Para P8, o machismo deveria ser debatido dentro das políticas de direitos humanos, uma vez que favorece várias formas de violência.

Eu debato com companheiros e companheiras que eu acho que um dos principais fatores que deveriam ser debatidos, que não é debatido em nada na área dos direitos humanos, é pensar a questão do machismo. O machismo não está em debate em lugar algum, não existe política de combate ao machismo no Brasil. Existe combate à violência contra a mulher. A violência contra a mulher é a barbárie do machismo. O machismo está impregnado em cada indivíduo, em cada homem e em cada mulher, no seu cotidiano, (...) as pessoas naturalizam o machismo. Eu acho que ter mais de $50 \%$ da população brasileira vítima dessa forma de opressão, deveria se dar uma prioridade. (P8)

Para Chejter (2010), o sexismo permite aos homens assegurarem-se do acesso legítimo ao corpo da mulher. "Prostituir é apresentado como um direito dos homens" ${ }^{46}$ (Chejter, 2010, p. 10). Para Damásio de Jesus (2003), a exploração é favorecida pela feminilização da pobreza.

Outro fator que aparece com frequência é a vulnerabilidade de crianças e adolescentes. Para P4, a condição de pessoa em desenvolvimento facilita o aliciamento. Na infância e adolescência, na visão do entrevistado, além das questões socioeconômicas comuns à maioria das histórias sobre tráfico, as questões do imaginário, dos sonhos aparecem muito frequentes. Ser modelo, atriz, jogador de futebol é o sonho de muitos jovens que em razão disso são facilmente aliciáveis pelo tráfico.

A vulnerabilidade, se a gente pensar no adulto, a vulnerabilidade social, econômica. Mas, para o adolescente e a criança, não só isso. Eu acho que também isso, mas também ao fato dele ser vulnerável como pessoa, ainda está em formação, e a sedução de dizer que o cara vai jogar no Barcelona ou no Real Madri, ou que ela vai ser uma modelo famosa, uma atriz famosa em Hollywood, talvez pegue a vulnerabilidade de formação, ela nem precisaria estar vulnerável em termos econômicos e sociais, a gente pode ter um menino de condição econômica bacana e que foi aliciado por conta de um sonho, que não necessariamente ele estaria vulnerável econômica ou socialmente. Então, eu acho que a vulnerabilidade é essencial. (P4)

\footnotetext{
${ }^{46}$ Prostituir entendido como explorar a prostituição.
} 
Não se pode desprezar que apesar de haver esta sedução pela fama, na maioria dos casos a criança é subtraída da sua infância em razão da vulnerabilidade socioeconômica, como apontada por Damásio de Jesus, (2003), sendo necessário que seja feita uma análise mais ampla quando se trata de criança e adolescente.

As questões que envolvem a infância levam necessariamente a uma reflexão sobre o lugar ocupado por estes sujeitos dentro do nosso ordenamento jurídico e dentro das políticas públicas. Desde a Constituição Federal de 1988 (BRASIL, 1988) e a promulgação do Estatuto da Criança e do Adolescente em 1990 (BRASIL, 1990), o Brasil vive uma nova era de atenção à criança e ao adolescente. Da doutrina da situação irregular o Brasil ingressa na doutrina da proteção integral. Por via constitucional,

É dever da família, sociedade e do Estado assegurar à
criança, ao adolescente e ao jovem, com absoluta
prioridade, o direito à vida, à saúde, à alimentação, à
educação, ao lazer, à profissionalização, à cultura, à
dignidade, ao respeito, à liberdade e à convivência familiar e
comunitária, além de colocá-los a salvo de toda forma de
negligência, discriminação, exploração, violência, crueldade,
opressão. (Art. 227, CF/88).

Os dados apontam que, apesar da previsão constituição e da implementação de políticas específicas de direitos das crianças, o número de vítimas de violência na faixa etária de < 1 a 19 anos é assustador. Dados do Sistema Único de Saúde - SUS - em 2011, coletados por meio do Sistema de Informação de Agravos de Notificações do Ministério da Saúde - SINAN, revelam que $40 \%$ dos atendimentos feitos pelo SUS em 2011 se referiam a crianças e adolescentes. Deste total, 40,5\% foram vítimas de violência física, $20 \%$ de violência sexual, $17 \%$ vítimas de violência psicológica ou moral, $16 \%$ vítimas de negligência e abandono e 4,1\% vítimas de exploração sexual (WAISELFISZ, 2012).

Quando se trata de crianças e adolescentes, é fundamental lembrarmos que estes sujeitos pouco participam da elaboração e execução das políticas a eles destinadas. Crianças e adolescentes, incapazes no sentido civil do termo, são vulneráveis em si, pela própria condição de pessoa em desenvolvimento. 
Diante disso, P5 alerta para o fato de ser necessário um tratamento diferenciado à criança e ao adolescente vítimas de tráfico, comparado ao tratamento dado ao adulto. Por serem sujeitos em formação, as ações de proteção e acolhimento tem que ser cuidadosas, visando a evitar que haja uma revitimização em razão da maior vulnerabilidade dos sujeitos.

Aconteceu o tráfico de adolescentes para prostituição, todos travestis, ou como a faculdade de psicologia me pediu, todos com transtorno de identidade de gênero. Vieram uns 13 do Pará, são adolescentes, não tem formação, não tem vontade perfeita, é uma vontade no imaginário, você tem que saber lidar.... "Não, vamos devolver para o Pará". Não pode, você tem que ter uma tutela muito diferente da que se tem com o adulto, não dá para mandar para um lugar. Com o adolescente você tem que ver o que está acontecendo, quem vai receber no Pará. Mas é mais fácil lidar com adolescente que com o adulto. Só que os adolescentes que a gente tem recebido do exterior, eles são poucos, eles entram na rota da prostituição e na rota da prostituição eles contam com a conivência de muita gente. (P5)

A possibilidade de a vulnerabilidade transcender à questão socioeconômica também para os adultos, aparece na fala de P5. Para o entrevistado, a preocupação da mulher-mãe a torna vulnerável, por medo de represálias aos filhos. Relata um caso de uma mulher instruída, com boas condições financeiras, que foi embora do Brasil com seu companheiro e no destino acabou sendo restringida em seus direitos por ele. Não seria um caso de tráfico, mas, no ponto de vista do entrevistado, reforça a ideia de que muitas vezes a pessoa se encontra vulnerável não apenas pelas questões socioeconômicas, mas pela preocupação com a família (sobretudo filhos), por uma baixa autoestima, por falta de perspectivas no futuro.

Cai aquele mito de que a vítima é uma pessoa pobre, ignorante, sem recurso algum. Não. Às vezes a vulnerabilidade não é só econômica. A vulnerabilidade no caso ali é a condição de mãe, ela não pode fugir com as crianças, é difícil, não tem família mais no Brasil, se perdeu, são outras coisas que determinam a vulnerabilidade. Não só econômico. Se ela fosse solteira, mas com criança, não vai poder fugir, depende economicamente... Quando você acha que a pessoa é ignorante demais, pensa que se ela soubesse ela não ia cair. Cai. Quantos mineiros não caíram numa roubada, caíram no submundo do crime por que eles 
entram sem o green card. Eles se chocam, poque eles são pessoas que aqui são classe média. Eles não precisariam se submeter a trabalho ou a coiotes para exploração, ficam devendo horrores. (P5)

A relação entre vulnerabilidade, violência e aliciamento fica muito explícita nas entrevistas. Quando se observa que existe uma cadeia de violências e que o tráfico de pessoas aparece como o último elo a levar o indivíduo ao fundo do poço do assujeitamento e da subjugação, isso nos leva a pensar na importância de uma política de prevenção eficaz. É o que inferimos da fala de P2 e de P1, quando refletem sobre a existência de uma cadeia de violências como favorecedora do tráfico:

Então veja como esta situação tem um encadeamento de outras violências até chegar até aqui. Ela começa no espaço privado e vai para o espaço público, até terminar na morte ou na situação do encarceramento dessa mulher. (P2)

Porque quando você fala de pessoas traficadas ou de contrabando de migrantes ou você tem gente na linha da miséria ou você tem gente que sofreu algum tipo de violência familiar, algum tipo de exclusão, você pode ir atrás que você vai enxergar. O desejo por uma vida melhor, eu lembro muito claramente as pessoas que migravam para os EUA, muitas delas vinham de Minas, era tudo gente ou que perdeu tudo, estava morrendo de fome, ou a filha que não aguentava mais apanhar do pai e queria romper, a mulher que não aguentava mais a violência dentro de casa, enfim, era tudo, feita uma investigação pormenorizada, estava muito claro isto aí. Não vou dizer que em $100 \%$ dos casos, mas eu vou dizer que na expressiva maioria, (...), a pessoa que chega a ser traficada está no último do último estágio de vulnerabilidade a torná-la alguém aliciável a se qualificar como mercadoria, como coisa. Este é o último estágio das múltiplas situações de fragilização que ela suporta no histórico de vida pessoal dela. (...) Mais do que romper o ciclo de vitimização de quem já foi traficado ou está sendo traficado é você romper o ciclo daqueles que são vítimas de violência e que podem ser traficados. (P1)

Para $\mathrm{P} 1$, a atenção dos profissionais e dos agentes de políticas tem de estar voltada para a prevenção. É necessário que haja uma oitiva atenta, um atendimento que identifique violações e que as compreenda como peças de um ciclo muito maior que a queixa expressada. Desafio maior que salvar as vítimas do tráfico é conseguir evitar que haja vítimas do tráfico. 
(...) a coisa mais comum do mundo é no dia a dia de um promotor no atendimento ao público baixar alguém que foi vítima de violência. Se ele encontrar um não lá, você estará devolvendo ele pro mundo dizendo o seguinte: "Meu, se vira", nesse "se vira", esse camarada pode facilmente entrar numa rota dessas qualquer. (P1)

Um outro ponto interessante apresentado pelos entrevistados é a relação que a vítima do tráfico muitas vezes tem com relação a seu país de origem. Para o entrevistado, a imagem que se vende do Brasil favorece um descontentamento, uma insatisfação para grande parte das pessoas que buscam uma vida melhor em outros países. Além de favorecer o imaginário de que tudo que vier de fora é melhor, muitas pessoas vinculam o Brasil à pobreza, ao jeitinho, à corrupção, criado uma imagem de que nada dá certo. Assim, a promessa de vida melhor em outros países é facilmente assimilada como possível, diante da baixa autoestima do povo, aqui, na fala do entrevistado, englobando também a classe média.

A própria classe média tem uma baixa autoestima. É só no Brasil que é ruim, é tudo corrupção, é tudo uma porcaria. A imprensa incentiva muito isso. Se você elogiar o governo, não sai uma linha, se criticar o governo, sai uma manchete. Se eu mostrar uma política pública que funciona, ninguém quer saber. Nós só gostamos de vender notícia ruim. Isso chega na população, a população foco do tráfico acha que vai encontrar uma Paris maravilhosa. E aí, entra na mão da máfia russa, vai sem os documentos, não conhece língua alguma, se submete ao pior tipo de prostituição. (P4)

Se até agora tratamos das violências que levam ao tráfico, é fundamental tecermos uma reflexão sobre as violências dele decorrentes. As violências apontadas como decorrência do tráfico de pessoas também são vinculadas a vulnerabilidades. No caso de vítimas de tráfico que são migrantes, em sua maioria irregulares, as maiores violações são provocada pela omissão do Estado no que tange à regularização documental dos migrantes.

Quando a gente trabalha com a mesma população que é objeto do tráfico, os bolivianos, a Polícia Federal estava exigindo deles a autorização do pai para que a criança fosse registrada no Brasil. (...) não havia fundamento legal para se pedir a autorização do pai para se regularizar a situação da criança no Brasil. A partir do momento em que você impede a regularização dos estrangeiros indocumentados, você cria um submundo. São pessoas que são mais vulneráveis, elas 
não tem nada, não tem um documento brasileiro. (...) também não adianta tentar ser mais realista que o rei. Se deixa entrar, regulariza... não adianta depois que entrar impedir a regularização. Se a gente impede a regularização nós criamos submundos, submetidos a tráficos, a gangs, a máfias, ' $n$ ' coisas, a exploração, aumentamos a vulnerabilidade e isso é perigosíssimo... trabalhei junto com a Defensoria Pública da União, deu certo, e foi uma vitória dos bolivianos. (P5)

A falta de documentação também favorece outros tipos de violências. Os migrantes irregulares acabam ficando à margem do sistema de Justiça, o que se traduz no grande número de bolivianas vítimas de violência doméstica. Esta foi a conclusão a que Teles (2007) chegou, e se retrata na fala de P6.

Provavelmente se sentem na ilegalidade, não tem
documento, se acham errados, culpados e por isso aceitam
esta exclusão, tem medo de reclamar. Eu ouvi relatos das
mulheres que sofrem violência doméstica. As promotoras da
violência domestica da capital me falaram, empiricamente
também, que $50 \%$ das mulheres que lá aparecem são
bolivianas, vítimas. (...) Essas mulheres são agredidas, mas
poucas delas tem a coragem de dar andamento a estes
processos, pela condição econômica, por não estarem
legalizadas no país, por uma série de questões que elas não
conseguem... para elas é mais difícil ainda que para as
brasileiras, denunciarem a violência doméstica e seguirem
como processo. (P6)

Além da falta de documentos, a falta de redes de proteção que os apoie e oriente sobre os direitos num país estranho os põem à margem de direitos básicos como uma moradia, acesso à rede regular de ensino (WALDMAN, 2012), acesso à saúde (TELES, 2007), acesso à justiça. O comprometimento no acesso à educação também para a população de bolivianos é apontado por P6

Um promotor dos direitos humanos, da inclusão social, aqui da promotoria dos direitos difusos da capital (...) tem um inquérito civil para apurar 0 acesso da população de bolivianos às políticas públicas, porque se tinha notícia de bulling nas escolas, de escola que não fazia matrícula. Naquele inquérito a gente via que aquela população não tinha acesso às políticas publicas. E um dado que não é oficial e que me foi passado é que há uma população de 450 mil bolivianos em São Paulo, na capital. (P6) 
A falta de conhecimento sobre os direitos faz com que haja um temor por parte das vítimas do tráfico de pessoas em procurar os órgãos públicos. Esse temor é apontado por P8

Mas os trabalhadores aqui no Brasil e em muitos casos as vítimas de exploração sexual também, elas acabam sendo atemorizadas por uma situação de viver a margem da ordem legal. "Se você sair aqui da porta e pedir auxílio prá polícia, é pior. A polícia aqui é agressiva, a polícia deporta, você vai sair com uma mão na frente e outra atrás, ainda vai ter que pagar multa". Cria-se uma política de temor na pessoa. A mesma coisa com a prostituta, que já carrega o estigma social de ser prostituta, e dali o cara ainda fala que está fazendo uma coisa que é irregular, "você não pode ser puta, você sabia disso, se você fizer isso pode ser presa". Cria essa situação de temor que acaba impedindo que essa pessoa se organize, que essa pessoa busque os órgãos públicos, busque o auxílio de todos os órgãos possíveis. Eu acho que a solução efetiva ela é só política, isso são as minhas convicções. (P8)

Não podemos colocar toda a responsabilidade da marginalização do migrante irregular nas costas do migrante. Não podemos acreditar que tudo se resolveria se o migrante procurasse auxílio junto ao poder púbico, que com isso todos os seus direitos seriam respeitados. Na maioria das vezes a proteção aos migrantes se faz por meio de organizações não governamentais como o Centro de Apoio ao Migrante (CAMI) ${ }^{47}$, o Serviço Pastoral do Migrante (SPM), o Cáritas. A ação dos órgãos públicos na atenção ao migrante é precária, e isso é relatado por P8, sobre a falta informação, de orientação e de sintonia entre a atuação dos diversos órgãos:

Porque cá entre nós: a Polícia Federal não orienta quase nada. Até posso dizer que a Polícia Federal é uma das instituições mais complicadas de se trabalhar. Eles não tem aquela visão... Os países tem alguns acordos internacionais para regularização da migração, principalmente aqui no Mercosul. Eles tem direito de permanecer no Brasil e de trabalhar aqui, regularmente. Eles só precisam passar por um procedimento para se regularizar. Uma coisa que nem é tão complicada, inclusive se eles fizerem dentro de um determinado prazo, antes deles estarem irregulares, é mais

\footnotetext{
${ }^{47}$ O principal trabalho do Centro de Apoio ao Migrante (CAMI), consiste em regularização migratória, assessoria jurídica especializada, assistência psicossocial, articulação com organismos governamentais e não governamentais. (ILLES, TIMÓTEO E FIORUCCI, 2008)
} 
fácil ainda. Então é uma questão de informação, não é uma questão de ter direito ou não ter. eles tem o direito, só não sabem o que tem que fazer. Muitas vezes a pessoa já está irregular, ela vem com um visto de turista, vence esse visto de turista, ela poderia sair do pais, esperar regularizar, ou permanecer aqui esperando regularizar, só que eles vão na PF e a PF diz que eles estão irregulares e tem 08 dias para sair do país. Uma pessoa que não tem dinheiro nem para comer direito, você acha que ela vai comprar uma passagem para ir para a Bolívia? Ela volta para a oficina de costura e nunca mais sai de lá. (P8)

Para P5, o Estado tem que proteger o migrante. Uma vez que permite a entrada, tem que garantir a existência no país e isso só é possível com a legalização de seu registro. A falta de documentação que regularize sua situação no Brasil leva os imigrantes a temerem ser pegos. Por se sentirem na ilegalidade, acham-se errados, culpados e por isso aceitam ficar à margem, o que leva à exclusão das redes de proteção jurídica.

A terminologia é "estrangeiros indocumetados". É importante
você trazer um registro dessa pessoa, porque primeiro, se
ela foi traficada ela nunca vai ter documento, se ela foi
traficada, ela vem documentada, o documento fica com o
traficante, ela sabe disso, cria uma vulnerabilidade. Se você
cria um empecilho para documentar esta pessoa, aí vocês
está fazendo a política do traficante. Não podemos liberar
geral, mas também devemos ser mais razoáveis na
documentação. (...) O Brasil tem que proteger aquela
pessoa, a pessoa humana, independente. (P5)

A falta de documentação que regularize a estada do imigrante no Brasil impede, por exemplo, que consiga abrir contas em banco, fazendo com que fiquem vulneráveis à ação de bandidos. Isso porque, sabendo que guardam dinheiro em casa, assaltam as moradias coletivas em busca de dinheiro, provocando atos de violência como o que aconteceu em 28 de junho de 2013 na Zona Leste de São Paulo, situação em que um assalto terminou com a morte de uma criança de cinco anos (Folha, 2013; CBN, 2013). O estado de São Paulo não tem números oficiais sobre violência cometida contra imigrantes, uma vez que as ocorrências são registradas segundo a natureza do crime, não havendo registro sobre as características das vítimas. 
A regularização dos documentos, a inserção política, a inserção comunitária são passos importantes para que as vítimas se percebam como sujeitos de direitos. Para P8

Só política faz andar. Um trabalho efetivo com as pessoas, ter um trabalho de inclusão dessas pessoas, porque eu acho que a inclusão política dessas pessoas é o primeiro passo. Regularização da condição enquanto nacionais. Uma coisa que a gente vê com muita frequência é: a gente vai lá, arrebenta o lugar, vê 15, 50 trabalhadores em situação de trabalho escravo, faz a operação com o Ministério do Trabalho, com a polícia federal, você vê aquele pessoal, naquela penúria, trabalhando de 6 às 11, comendo e dormindo do lado da máquina de costura. Qual é a primeira providencia que a Polícia Federal faz: ela vai lá e multa o sujeito porque está aqui irregular! A inserção política dessas pessoas e a inserção comunitária delas, de participação, de saber que elas são tão inseridas politicamente, tão inseridas num ambiente que é democrático, é um passo e tanto para a superação disso, da auto-organização de todas as pessoas vitimizadas, sejam os trabalhadores escravos, sejam as vítimas de exploração sexual, seja quem for. Saber que elas são agentes políticos também, saber que elas são pessoas que ali tem direitos também, tem direitos e tem deveres, é imprescindível. (P8) 


\section{3 - Categoria 3 - Desafios: Maiores dificuldades em trabalhar o tema tráfico de pessoas.}

A política de enfrentamento ao tráfico de pessoas enfrenta alguns limitadores para a sua efetividade. Em suas atuações como membros do Comitê os entrevistados puderam observar alguns pontos de fragilidade na execução dessa política. A reflexão sobre estas lacunas poderia servir como norteador de ações que a potencializassem.

Na categoria "Desafios: Maiores Dificuldades em Trabalhar o Tema Tráfico de Pessoas e Direitos Humanos" foram agrupados fragmentos que permitissem uma análise dessas fragilidades.

Um ponto recorrente na fala dos entrevistados se refere à invisibilidade do assunto. Para muitos a falta de conhecimento sobre o tema, seja pela sociedade de um modo geral, seja pelos profissionais envolvidos na política, seja no universo acadêmico, é um limitador à eficácia do enfrentamento. Dar visibilidade ao tema, tornar o assunto de conhecimento generalizado é apontado como fundamental.

A relevância em desenvolver uma pesquisa acadêmica sobre o tema foi pontuada. Para P2, discutir de forma "qualificada e técnica" é importante.

Fico feliz em saber que você vai usar em seu doutoramento, mesmo que seja como pano de fundo, a temática do Tráfico de Pessoas, porque nós temos no mundo acadêmico muito pouco material sobre isso e a sua pesquisa para nós é de grande valia. Isso significa que a gente vai tirar da invisibilidade e vai colocar no meio acadêmico até como forma de você discutir de maneira mais qualificada e técnica, dentro desse meio a questão, porque o grande problema que nós enfrentamos com o Tráfico de Pessoas é a invisibilidade da temática. (P2)

A invisibilidade da temática mencionada pelo entrevistado pode ser negativa em vários sentidos. A invisibilidade acadêmica acaba por fazer com que haja pouco conhecimento técnico sobre o tema, o que pode prejudicar o 
desenvolvimento de políticas públicas relacionadas, uma vez que as políticas também são guiadas pelo conhecimento científico produzido sobre o assunto. Como mencionado na apresentação e no capítulo 3 , houve um aumento significativo no número de trabalhos acadêmicos sobre o tema Tráfico de Pessoas. Entre 2004 e 2011 foram cadastradas 28 dissertações e três teses. Em 2012 e 2013 (até o momento), foram cadastradas 11 dissertações e uma tese. Este aumento pode ser explicado pela adesão do país ao Protocolo de Palermo e à introdução da Política Nacional de Enfrentamento ao Tráfico de Pessoas, com a elaboração dos I e II Plano Nacional de Enfrentamento ao Tráfico de Pessoas.

No que se refere à invisibilidade social, a falta de informação sobre o tráfico acaba por favorecer o aliciamento de pessoas que, desconhecendo a existência desse tipo de prática criminosa, acabam por serem mais facilmente envolvidas por grupos envolvidos com o tráfico de pessoas. Entre o final de 2012 e meados de 2013 foi exibida a novela Salve Jorge (Globo, 2013), que acabou tendo um papel importante para divulgar o tema. No entanto, alguns entrevistados temem que as pessoas achem que "é coisa de novela". É o que se infere da fala de P6, quando faz uma reflexão sobre o desconhecimento da sociedade, exemplificando com a própria família.

Na minha família, nos meus familiares... eu vejo que há uma falta de informação geral, que com campanhas publicitárias fortes... precisava de campanha. A novela vai explodir, mas as pessoas vão continuar achando que é mito, que é coisa de novela, que a mulher vai porque ela quer, que a prostituta se prostitui porque quer...(P6)

O desconhecimento sobre o tema muitas vezes faz com que as pessoas olhem de maneira preconceituosa para as vítimas do tráfico, sobretudo as vítimas de exploração sexual (GRUPO DAVIDA, 2005). Essa postura pode ser verificada no mal-estar que a prostituição ainda provoca em grande parcela da população e pelo viés da moralidade pública que ainda exacerba as decisões judiciais sobre o tema (CASTILHO, 2008).

A vinculação do tráfico para exploração sexual à prostituição é favorecida pelos próprios dispositivos legais - artigos 231 e 231-A do Código Penal - que tratam do Tráfico internacional de pessoa para fim de exploração sexual e do 
Tráfico interno de pessoa para fim de exploração sexual que dispõem, respectivamente:

Art. 231. Promover ou facilitar a entrada, no território nacional, de alguém que nele venha a exercer a prostituição ou outra forma de exploração sexual, ou a saída de alguém que vá exercê-la no estrangeiro. (Redação dada pela Lei no 12.015, de 2009)

Art. 231-A. Promover ou facilitar o deslocamento de alguém dentro do território nacional para o exercício da prostituição ou outra forma de exploração sexual. (Redação dada pela Lei $n^{\circ}$ 12.015, de 2009)

Ambos dispositivos incluem a prostituição como conduta a ser combatida, quando, na verdade, a legislação brasileira, a princípio, não pune a prostituição. $O$ Projeto de Lei do Senado (PLS) no 429/2013, prevê, entre outras questões, a supressão da prostituição como forma de exploração sexual, preferindo-se o uso de termo genérico de "exploração sexual". Esta proposta visa a reforçar a situação de legalidade de quem presta serviços sexuais e pontuar que, no caso do tráfico de pessoas, a condição de vítima destes sujeitos.

A relação da prostituição com a exploração sexual é apontada por P2:

Veja, eu acho que existe um tabu muito grande e um desconhecimento também quando as pessoas vão discutir a temática do Tráfico de Pessoa. Quando você fala de Tráfico de Pessoa a primeira imagem e a primeira referencia que as pessoas fazem é: "Ah, aquelas mulheres que vão dançar e se prostituir lá na Espanha"; "É prostituta, elas vão porque elas querem". Esse é o primeiro tabu e o primeiro mito que encontramos. As pessoas sempre associam tráfico de pessoas com exploração sexual ou prostituição para fins de exploração sexual. (P2)

Para alguns entrevistados, a novela "Salve Jorge", da autora Glória Perez, foi apontada como importante divulgadora do fenômeno e possível desconstrutora de algumas imagens equivocadas sobre o tráfico de seres humanos, sobretudo com relação à vítima. Para $\mathrm{P} 7$

Eu acho que a novela, por incrível que pareça, começou a desmistificar um pouco isso. Eu via que a própria sociedade tinha um preconceito muito grande com relação a isso, 
ninguém acreditava, achava que era aquela questão de lenda urbana. "A menina foi prá lá, enganada? Imagina! Ela foi porque quis, bem feito", só faltava falar isso. Então eu acho que esse preconceito ainda existe, mas eu fiquei muito feliz quando soube que esse tema ia ser abordado. (...) Entraram em contato comigo também. Deu uma dimensão bem real, séria a respeito da vítima, de que a pessoa não vai para fazer uma coisa errada, ela vai procurando uma qualidade de vida melhor, condições de vida melhor, dignidade. Eu acho que esse preconceito vindo em geral da sociedade, que acaba afetando as próprias pessoas, também era uma questão que já pode ter reduzido, não diria anulado, porque não é todo mundo que assiste à novela, mas eu acho que ainda popularizou o tema, deu visibilidade para a questão da boa fé da pessoa. Não só para o problema em si, que também era muito importante, mas pra a a boa fé da vítima, que estava fazendo o que qualquer um estaria fazendo no lugar dela. (P7)

P3 também destaca a importância da novela para popularizar o tema

O primeiro desafio com relação ao Tráfico de Pessoas é dizer o que é o fenômeno, esclarecer. Muita gente vai dizer que se isso existir é federal, não é de competência da Polícia Civil. A autora Gloria Perez foi chamada pelo Ministro da Justiça e a próxima novela das oito será sobre Tráfico de Pessoas. Isso vai mudar muita coisa. Da mesma forma que você chama atenção para o tema externamente, tem que chamar atenção internamente: existe este tipo de crime acontecendo. (...) Mas isso tem a ver com que? Com crime organizado? Com relação ao Tráfico de Pessoas há um problema de conhecimento. Não se conhece este fenômeno. Tem um problema de conhecimento de percepção. Entende que é outra coisa. (P3)

Além da novela funcionar como importante divulgadora do tema observamos também um aumento do número de reportagens jornalísticas sobre 0 assunto. Em rápida busca no site do Jornal Folha de S. Paulo com o descritor tráfico de pessoas, encontramos 464 ocorrências entre 2000 e 2013. Não fizemos uma análise pormenorizada do conteúdo das notícias, mas observamos haver um aumento crescente nos últimos anos: entre 2000 e 2008 foram verificadas 190 ocorrências e entre 2009 e 2013 encontramos 274 ocorrências $^{48}$.

\footnotetext{
${ }^{48}$ Pesquisa feita em 20/11/2013, no site www.folha.com.br. Importante ressaltar que nos anos de 2012 e 2013 verificamos um grande aumento das ocorrências, mas observamos que muitas ocorrências se referiam a informações sobre a novela Salve Jorge, que foi exibida entre outubro de 2012 e maio de 2013.
} 
A conscientização das vítimas e dos membros de movimentos sociais que lidam diretamente com a sociedade civil é uma preocupação de P2, que fala de uma ação concreta no sentido de capacitar lideranças comunitárias sobre o tráfico de pessoas.

O que a gente tem feito é, através da formação de lideranças comunitárias, tem até um projeto em que nós atuamos há 10 anos em parceria com uma outra organização, chama GUELEDES, Instituto da Mulher Negra, que é o de Projeto Promotoras Legais Populares. Nesse projeto, em que a gente faz a formação de lideranças comunitárias de mulheres para a questão da cidadania e Direitos Humanos, sempre com o viés étnico racial, a gente tem um módulo de violência de gênero onde a gente tem uma cadeira específica que é Tráfico de Pessoas. Porque a gente precisa instrumentalizar, empoderar estas pessoas de conhecimento para que elas possam no seu dia a dia conseguir identificar. (P2)

A falta de conhecimento é ainda maior quando se trata do tráfico de pessoas para fim de tráfico de órgãos. Para $\mathrm{P} 3$, o tráfico de órgãos também é tratado como "lenda urbana".

O grande desafio, pelo menos da minha instituição e de fato de outras, dei palestras em vários lugares no Brasil, é chamar a atenção para o tema, tornar isso um objeto de conhecimento. É um objeto a ser conhecido, porque, as formas de percepção que se tem desse objeto é que no máximo, se formos falar de Tráfico de Pessoas em São Paulo estaríamos falando em oficinas de costura, em bolivianos escravizados. É esta relação que se faz. Se aprofundar um pouco mais vai confundir com prostituição. Tráfico de órgãos é lenda urbana. (P3)

Perguntado sobre a dificuldade de a sociedade reconhecer o tráfico de pessoas, $\mathrm{P} 2$ reflete.

Primeiro o tabu, segundo a invisibilidade. O Tráfico de Pessoa acaba se tornando algo invisível porque as pessoas não conhecem, não sabem o que é. Como eu não conheço, não consigo combater este inimigo invisível. Na medida em que eu passo a conhecer, a saber quem é, como ele se manifesta, ele deixa de ser um ente abstrato, ele deixa de ser algo ficcional e vira algo real. (P2) 
A invisibilidade do tema entre os profissionais do direito é também uma preocupação, uma vez que recebem denúncias sobre diversos assuntos, e é fundamental que consigam identificar nas violações a dimensão do tráfico de seres humanos. O desconhecimento do tema entre os profissionais revelado por P6, quando fala de questionamento feito por colegas de profissão.

"Mas isso existe aqui? Tem mesmo ou é só lenda urbana? Isso é da competência estadual, o que a gente tem a ver com isso?" dentro do MP, que é composto por várias áreas. (P5)

Para P3, o conhecimento do tema entre os profissionais envolvidos no enfrentamento é fundamental.

Na doutrinação ou na análise de discutir, é sempre um tripé, e acaba parecendo que é só isso. Mas tem, por exemplo o tráfico para fins de adoção. $O$ norte deve ser a violação de direito. Senão acaba-se lidando com estereótipos. O maior desafio, antes de entrar no debate sobre Direitos Humanos é transformar isso como um objeto a ser conhecido pelas instituições formais que vão lidar, seja no eixo prevenção, repressão ou atendimento à vítima. Porque você não sabe com o que está lidando. (P3)

O conhecimento da política e seus propósitos necessariamente têm de ser de conhecimento dos agentes públicos que lidam com o tráfico. A política nacional é pautada pelo tripé prevenção, repressão e acolhimento à vítima, sendo orientada pelo Protocolo Adicional à Convenção das Nações Unidas contra o Crime Organizado Transnacional Relativo à Prevenção, Repressão e Punição do Tráfico de Pessoas, em Especial Mulheres e Crianças.

Apesar das possíveis agendas para o tratamento do tráfico, este fenômeno tem sido tratado com maior incisão sob o viés do controle de criminalidade e prevenção. $\mathrm{O}$ acolhimento à vítima tem sido prejudicado. Se considerarmos que as vítimas do tráfico de pessoas são em sua grande parte migrantes e mulheres exploradas sexualmente, o que observamos é que há um tratamento pouco cuidadoso a esses sujeitos.

É o que encontramos na fala de P8, para quem o conhecimento dos órgãos oficiais é importante, mas acabam usando o conhecimento e as informações para 
a repressão do tráfico, não havendo uma preocupação real com a vítima, com o acolhimento. A conscientização, para P8, é fundamental para acabar com a invisibilidade do fenômeno e proteger as vítimas.

A principal lacuna é o trabalho de conscientização desses sujeitos, das vítimas. Porque, acaba tendo visibilidade, mas são para pessoas que não são as vítimas, são aquelas pessoas que vão ter um olhar crítico para ver o sintoma social e perceber aquilo, isso para aquelas poucas pessoas que conseguem ter acesso às informações e são de um caráter meio denuncista. Do tipo: se você vir uma situação como esta, liga no número tal e faça a denúncia. Para ter a ação repressora para aquilo. Sabe-se lá o que vai-se fazer com o trabalhador ou coma menina prostituída, ou como menino prostituído. Sabe-se lá. O caráter é de repressão. Isso dá visibilidade, isso pega bem, isso sim. $E$ em casos isolados e pontuais. A questão de conscientização dessas próprias vítimas é o que eu acho ser o principal problema. Para que a pessoa se veja numa condição de vítima. Entenda o que é ser vítima disso. (P8)

A falta de uma pesquisa que mapeie o panorama do tráfico no Brasil também é um problema destacado pelos entrevistados. A pesquisa é apontada como importante para que o fenômeno seja conhecido, uma vez que houve uma mudança no perfil da vítima, uma mudança na dinâmica do tráfico do Brasil. É o que se infere da fala de P2

Há um tempo atrás São Paulo era passagem, hoje São Paulo está fazendo o duplo movimento, tanto de oferecer mão de obra quanto de ser rota de passagem para estas pessoas traficadas. $O$ que a gente precisa entender nesse contexto de quase 10 anos de política de enfrentamento ao Tráfico de Pessoas, a gente precisa entender que 0 panorama mudou. (...) Falta uma pesquisa que mapeie o panorama atual da situação do tráfico de pessoas no Brasil. A última pesquisa que nós temos é a PESTRAF ${ }^{49}$ que é de 2003, já vai pra quase 9 anos. O cenário nacional, a temática do tráfico mudou, é outra. Se antes a grande problemática era o tráfico para fins de exploração sexual, hoje não é. Hoje você tem outras modalidades tão graves, com tantas ou mais demandas do que aquela. Você tem no Brasil situações diferenciadas sobre o tráfico e você não tem uma pesquisa que mapeie quem são estas vítimas, quem são estes sujeitos que estão sendo traficados, que saem do

\footnotetext{
${ }^{49}$ Pesquisa Nacional sobre Tráfico de Mulheres, Crianças e Adolescentes (LEAL; LEAL, 2002).
} 
nosso país e que chegam aqui, porque agora a gente tem uma outra demanda, a gente tem os haitianos. Agora não é nada, mas daqui a pouco é outra demanda, você já tem os bolivianos, agora você tem os haitianos, e outras pesquisas que mapeiem as novas rotas, a gente não sabe. (P2)

As pesquisas são colocadas como importantes para que as políticas sejam definidas, para que o poder público acredite que há muitas vítimas potenciais. Há uma unanimidade entre trabalhos acadêmicos e relatórios sobre a dificuldade na realização de uma pesquisa que mapeie de maneira precisa o fenômeno do tráfico de pessoas. Seja pela invisibilidade do tema (KAPPAUN, 2011), seja pela falta de conhecimento dos agentes públicos, que com isso subnotificam as ocorrências do tráfico (SENADO, 2012), seja por uma postura machista e patriarcal acerca da vítima (FERREIRA, 2009; AUSSERER, 2007; TERESI, 2007; PISCITELLI, 2008; SANTOS, 2009; KEMPADOO, 2005, BRUCKERT, 2002; GRUPO DAVIDA, 2005). A pesquisa referenciada pelo entrevistado - a PESTRAF (LEAL; LEAL, 2002), foi importante para abrir as discussões sobre o fenômeno do tráfico de pessoas, num momento em que não havia nenhum dado consolidado, e nem mesmo havia uma política nacional sobre o tema, mas hoje é apontada como insuficiente para servir de norte a ações efetivas (BLANCHETTE; DA SILVA, 2012, PISCITELLI, 2008).

Uma das dificuldades apontadas como barreira à quantificação do fenômeno é o descaso dos governos com as vidas vulnerabilizadas pela exploração. P4 faz uma comparação entre o tráfico de drogas e de armas, que são mais facilmente mensuráveis que o tráfico de pessoas.

Porque sem dúvida nenhuma, o tráfico de drogas e o tráfico de armas por terem um objeto que é fácil e possível identificar, faz com que a gente tenha números para apresentar e esses números para o governo e para alguns governantes é mais importante do que dizer que talvez salvou uma vida que a gente não sabe se salvou ainda, mas que a gente pode ter influenciado para uma pessoa, que a gente não consegue quantificar agora, que obviamente as ações para o tráfico de armas e de drogas, seja muito mais valorizado hoje pelo nosso país do que o enfrentamento ao Tráfico de Pessoas. Mas óbvio, dos números não se foge, e o gasto que se tem, ou o que se move para esse comércio de pessoa é altíssimo, é que os governantes precisam então acreditar que isso é um assunto importante, criar ações e 
dar continuidade, ainda mais agora com as olimpíadas, com a copa do mundo, eu só vislumbro o aumento de vítimas, o aumento de aliciadores, aumento do consumo de pessoas. (P4)

P1 coloca o reconhecimento do tema como algo importante e também a questão da mensuração como fundamental, por permitir a construção de indicadores. Perguntado sobre o que veria como empecilho para a implementação das políticas públicas em direitos humanos, fez a seguinte reflexão.

Eu acho que são dois momentos diferentes. Eu vejo primeiro
uma questão cultural, e cultural é o processo de acreditação,
você reconhecer aquilo como realmente algo essencial. Eu
acho que esta acreditação é fundamental. E o segundo
ponto que é um desafio a ser superado ainda é a
capacidade de mensuração, a capacidade de medir o quanto
que esta preocupação se traduz em resultados efetivos. É
difícil mas eu acho que essa questão da mensuração é uma
questão global em matéria de Direitos sociais, de gênero,
genericamente falando, mas que precisa estar muito
evidente também. Porque hoje, a cadeia de construção ela
sempre pressupor a construção de referenciais ou de
indicadores que possibilitem mensurar minimamente o
resultado daquilo que se prega. A acreditação hoje está
muito mensurada no tanto que você entrega,
fundamentalmente, para além do discurso. (P1)

Para P8, independente da falta de dados, de pesquisas, não há dúvidas de que o problema existe e que deve ser objeto de ações concretas.

Eu estive no ano passado na conferencia das partes, na agência da ONU que cuida do tráfico, e lá, colocaram em questionamento como houve uma alteração substancial de números (...) por exemplo, do biênio tal acharam mil casos de tráfico de pessoas. Isso reflete um crescimento ou isso reflete uma preocupação? Reflete uma atenção mais detida. Eu acho que independentemente de a gente saber se o número são 5 ou se são 20 mil, a questão é saber que o problema existe, dando visibilidade ou não, tem que se tomar providencia para tanto. Mas numa situação dessa, em que os dados são subfaturados e são subfaturados porque não se tem poder de quantificar isso efetivamente. $E$ o que importa de você saber se o movimento está em alta ou está em baixa, se o movimento tem visibilidade ou não, é que isso é um problema que existe, que ele é real. (P8) 
Outra questão que dificulta o enfrentamento ao tráfico é a falta da definição de um marco legal. Para P2, a invisibilidade do tema, a falta de um marco legal e a falta de capacitação são pontos frágeis no enfrentamento ao tráfico de pessoas.

Vou listar alguns prá você: a invisibilidade, a ausência de um marco legal normativo é muito sério. Você luta por alguém mas não tem algo que diga: isso é tráfico de pessoas e tem que ser punível como tal, você não tem agentes públicos e agentes políticos com esta perspectiva, falta capacitação para esse povo todo. (P2)

Para $\mathrm{P} 1$, a definição de uma regulação legislativa teria a capacidade de precisar que mundo é esse com o qual estamos lidando.

(...) Até a forma de medir isso tem um problema que ainda não foi solucionado e que talvez o segundo plano não solucione, mas dê um passo importante, que é a definição do marco legal, o marco legal ainda não está claro. O marco legal não é simplesmente eu ratificar, mexer em alguma coisa na legislação, é definir conceitualmente que mundo é esse, que contexto é esse aí, e com uma questão de coerência. Eu tenho falado isso de uma maneira bem enfática, pode ser que eu esteja errado, mas eu acho que eu não estou errado, eu tenho falado isso aqui no MP, eu falei isso na CPI do tráfico quando veio aqui, quando teve aquela audiência pública aqui na assembleia legislativa, com a CPI do Tráfico no Senado. (P1)

É assim também que P3 entende a importância da definição legislativa para o conhecimento do tema

Mas isso tem a ver com que? Com crime organizado? Com relação ao Tráfico de Pessoas há um problema de conhecimento. Não se conhece este fenômeno. Tem um problema de conhecimento de percepção. Entende que é outra coisa. Para conhecer tem que ter um marco legal, tem que ter posturas administrativas. A nossa forma das instituições policiais tomarem ciência é formalmente, faz um curso, aprende. (P3)

A definição de um marco legal à política de enfrentamento ao tráfico de pessoas, que aparece como de importância crucial para um melhor andamento da política na fala dos entrevistados, é também legitimada pela Comissão Parlamentar de Inquérito do Senado. Isso pode ser verificado na leitura do 
Relatório Final da Comissão Parlamentar de Inquérito (CPI) criada para investigar o tráfico nacional e internacional de pessoas no Brasil (SENADO, 2012).

Segundo o relatório (SENADO, 2012), uma das maiores dificuldades em realizar a investigação teve origem no fato de não ser possível um levantamento estatístico confiável sobre o número de tráfico de pessoas no país. Essa dificuldade, ainda segundo o relatório, deve-se à dificuldade de se identificar a conduta delituosa e ao fato da legislação penal reconhecer tão somente o tráfico para fins de exploração sexual. No relatório parcial que antecedeu o relatório em questão, a dificuldade se deve também ao fato do tráfico de pessoas "ser um crime carregado de nuances, muitas vezes, sua caracterização pelos agentes repressores ou mesmo pelos operadores do direito requer um certo nível de preparo e treinamento" (SENADO, 2011, p. 189).

$\mathrm{Na}$ tentativa de tentar suprir a carência de um marco legal, a CPI propôs o Projeto de Lei do Senado (PLS) oㅜ 766/2011, substituído pelo PLS 479/2012, ainda em tramitação. O novo PLS além de tipificar o crime de tráfico de pessoas, contempla os três eixos que devem nortear as ações de enfrentamento ao tráfico de pessoas, a prevenção, a repressão e a atenção à vítima. $\mathrm{O}$ objetivo do projeto é conceder maior carga normativa, alcance e generalidade aos princípios e diretrizes da Política Nacional de Enfrentamento ao Tráfico de Pessoas.

A definição de um marco regulatório consta também do II Plano Nacional de Enfrentamento ao Tráfico de Pessoas (BRASIL, 2013), que estabelece como Linha Operativa I o Aperfeiçoamento do Marco Regulatório para fortalecer o enfrentamento ao Tráfico de Pessoas, tendo como atividade "Produzir propostas normativas para o enfrentamento ao tráfico de pessoas".

Para P7 o tráfico de pessoas deve ser entendido como uma violação aos direitos humanos, e não somente como um crime.

Eu não vejo o tráfico como um crime. É a violação de mil direitos humanos, de direitos civis, econômicos e culturais, e também a questão do crime. Prá mim não é só prender o cara e acabou. Prender o cara é 10\% do problema. Eu não gosto nem de falar o conceito: tráfico de pessoas é um 
crime. Não é um crime. É uma violação de Direitos Humanos. (P7)

Esse posicionamento coincide com uma das propostas do PLS 429. Segundo o relatório da CPI sobre o tráfico de pessoas (SENADO, 2012), a definição do crime de tráfico de pessoas seria deslocada do Título IV ("Dos Crimes contra a Dignidade Sexual"), Capítulo V ("Do Lenocínio e do Tráfico de Pessoa para fim de prostituição ou outra forma de exploração sexual") para um novo capítulo intitulado "Dos Crimes contra a Dignidade da Pessoa", acrescido no Título I, "Dos Crimes contra a Pessoa". Esta alteração se justifica em razão do crime tráfico de pessoas visar proteger o bem jurídico dignidade da pessoa e não mais a dignidade sexual ou, ainda, a organização do trabalho e a questão migratória.

O mesmo entrevistado, quando perguntado sobre ser importante ou não a definição de um marco legal, traz uma reflexão sobre o risco de um marco ressaltar ainda mais o caráter repressivo da política, diminuindo a importância dos eixos de prevenção e atenção à vítima.

É, com certeza é. Acho que até pela personalidade, pelo entendimento de direitos do próprio sistema brasileiro, onde se entende que tudo que é crime está errado e o que não é crime não está errado. (...) Porque os Direitos Humanos não excluem a questão do crime, mas ele complementa. Mas como isso é importante para o sistema brasileiro, e para aqueles que atuam aqui, acho que isso é uma falha ainda, grave. Não que o enfrentamento não pode avançar, não pode criar outras formas, não é isso. Olhando do ponto de vista do sistema brasileiro é uma necessidade importante e que isso vai gerar visibilidade para as outras questões, seria um passo. A partir do momento que ele é crime ele também dá direito a indenização para as vítimas. É um passo importante sim. Eu não gosto de simplificar como um crime, por causa do que eu falei. Parece que você resume tudo á repressão. (P7)

Essa preocupação do entrevistado na articulação dos três eixos temáticos - prevenção, repressão e atenção à vítima - e não uma ação meramente focada na repressão parece legítima quando se analisa o conteúdo dos projetos de Lei propostos até 2009 para enfrentamento ao tráfico de pessoas. Em quadro sistematizado por Gueraldi e Dias (2012), sobre os Projetos de Lei da Câmara 
dos Deputados que tratam do tráfico de pessoas e temas conexos, de um total de 52 Projetos de Lei Principais e Apensados, 28 referem-se exclusivamente a ações de repressão, 15 a ações de prevenção e seis a ações de prevenção. Um projeto contempla os três eixos e dois contemplam prevenção e repressão. Este quadro acaba por revelar a forte sedução da política de prevenção e enfrentamento pelo viés repressivo, e o pouco cuidado com o acolhimento à vítima.

Entre as dificuldades para trabalhar o tráfico de pessoas, além da invisibilidade e da falta de uma regulação normativa apontados acima, a desarticulação da política apareceu como um fator decisivo. Em razão desse tema ter se apresentado de maneira recorrente, optamos por tratar a desarticulação como uma categoria à parte, problematizada juntamente com a interdisciplinaridade e com a articulação dos eixos temáticos. 


\section{4 - Categoria 4 - Vítimas: os sujeitos/objetos do tráfico de pessoas}

Um olhar sobre a vítima apareceu com frequência na fala dos entrevistados. Pudemos observar que a polissemia do perfil da vítima dificulta a construção de uma categoria unidimensional, uma vez que esta figura se transmuta em diversos papéis e é vista por diversos olhares. Talvez seja esta uma das grandes lacunas na política de enfrentamento ao tráfico de pessoas: acessar essa vítima, seja nas ações de prevenção, seja nas ações de acolhimento.

Quem são as vítimas principais do tráfico de pessoas, como o aliciamento do tráfico se dá, como a vítima é tratada, como ela se relaciona com o aliciador, como vê os sujeitos que as "salvam" das redes de tráfico foram alguns pontos destacados nesta categoria.

$\mathrm{Na}$ fala de alguns entrevistados pudemos observar que atualmente não é possível fazer uma definição precisa de que indivíduo seria vítima de que tipo de tráfico de pessoas. A exploração humana como um todo acaba levando a uma dificuldade em tratar de maneira estanque as vítimas, definindo, por exemplo, que a mulher é vítima de exploração sexual e o homem vítima de exploração do trabalho. O que se tem observado é uma mudança no panorama do tráfico de pessoas, que tem levado a uma ampliação das condutas criminosas e do leque de possibilidades de exploração. Para P2, essa mudança no panorama do tráfico fica clara:

O que a gente precisa entender nesse contexto de quase 10 anos de política de enfrentamento ao Tráfico de Pessoas, a gente precisa entender que o panorama mudou. (...) Antes a gente só achava que as mulheres estavam presentes no tráfico para fins de exploração sexual, hoje você vê as mulheres em outras modalidades de tráfico: tráfico para fins de trabalho escravo, inúmeras. A maioria são homens, mas as mulheres também estão lá. Pelo seguinte. Você vê aqui em São Paulo um fenômeno diferenciado. Você vê São Paulo recebendo e absorvendo mão de obra para fins de exploração de trabalho escravo, mão de obra imigrante, você vê bolivianas, mulheres do continente africano, de 
Angola, Senegal, também sendo recebidas para fins de trabalho escravo. Você vê também, outra coisa que a gente deixa de observar, que é o trabalho doméstico, a exploração do trabalho doméstico para fins urbanos. Mas até dentro do Brasil. (P2)

Alguns entrevistados ressaltam a distinção entre os tipos de exploração. $O$ tráfico de migrantes para fins de exploração do trabalho aparece em vários momentos, sobretudo o tráfico de bolivianos para trabalhar na indústria têxtil de São Paulo. Na fala de P7 e P6 observamos uma coincidência de sentidos quando expõem suas impressões sobre as vítimas bolivianas.

Eu vou te falar dos que eu tive contato, dos que eu atendi. A gente sabe que tem várias realidades, mas não vou falar do que estudei, mas vou falar do que eu vi. Essas pessoas que a gente atende aqui, normalmente são sulamericanos, na sua maioria bolivianos, muito trabalhadores, vou falar sobre a personalidade deles, porque com muitos eu tive contato pessoal, de dias, até vinham aqui para ligar para a família. São pessoas muito trabalhadoras. Eles tem em comum uma habilidade manual incrível, porque muitos deles nunca tinham pegado numa máquina de costura e dois dias depois já estavam costurando. Chegaram aqui de viagem, dormiram e no dia seguinte já estavam aprendendo a costurar. Muito pacíficos, extremamente pacíficos, chegando a ser até submissos. Acho até que por isso eles são um alvo fácil, porque eles se submetem a situações de trabalho muito exaustivo e não reclamam. Poucos reclamam. Um só fugiu. No máximo eles vão embora. "Não quer me pagar, tá bom, eu vou embora". Não são encrenqueiros. (P7)

Umas pessoas que perderam a cultura, não são nem de lá e nem de cá, não tem expressão cultural, e que ao contrário, tem formação, tem essa habilidade de costurar, tem uma índole pouco agressiva. Eles foram escolhidos eu acho que a dedo, porque a índole das pessoas é uma índole de não reagir, não sei se por formação histórica, cultural, religiosa, você vê que o Ministério do Trabalho faz normalmente as diligências sem polícia, porque não precisa, eles não reagem. Por informação eles não reagem. (P6)

A fala dos entrevistados reforça o que podemos observar em dados recentes sobre o tema. As principais vítimas do tráfico de pessoas no estado de São Paulo são homens, maiores de 18 anos, explorados para o trabalho escravo principalmente na indústria têxtil, oriundos principalmente da Bolívia (tráfico 
externo $)^{50}$. A exploração sexual ainda aparece como importante forma de exploração, mas não como principal. Considerando que as vítimas do tráfico de pessoas são em sua grande parte migrantes e mulheres exploradas sexualmente, o que observamos é que há um tratamento pouco cuidadoso a esses sujeitos.

O crime organizado transnacional e as leis de migração têm sido colocados no mesmo patamar, o que pode comprometer tanto as políticas migratórias, de inclusão e acolhimento ao estrangeiro, quanto as políticas de tráfico, que não conseguem garantir uma distinção eficiente dos fenômenos. Para Anderson e Davidson (2002), o tráfico coloca a migração no controle criminal, no contexto de prevenção criminal, mais do que no contexto dos direitos humanos, sendo muitas vezes utilizado como um veículo para desenvolver uma abordagem mais restritiva da imigração em geral. Musto (2009), corrobora com esta posição, fazendo ainda um questionamento sobre a inadequação do uso do termo tráfico, para fenômenos tão diversos. Piscitelli (2008) entende que as "acirradas discussões internacionais sobre o tráfico de pessoas têm lugar em contextos marcados pela obsessão com os migrantes não documentados" (2008, p. 35).

No que tange ao tráfico para fins de exploração sexual, o que temos observado é que as ações acabam por não fazerem distinção entre as pessoas vítimas de tráfico e as pessoas que se prostituem voluntariamente. Desse modo, a prostituição tem sido constantemente vinculada à exploração sexual, desconsiderando o fato de em muitas situações a prostituição ser uma escolha legítima da mulher. Este debate fica ainda mais complexo quando os movimentos pelos direitos das mulheres apresentam discursos discordes sobre o assunto.

Por um lado, para as feministas abolicionistas a prostituição é sempre e necessariamente degradante e danosa à mulher, e reduz a mulher à posição de objeto. Assim, elas reconhecem não haver distinção entre prostituição forçada e livre escolha, afirmam que tolerando, regulando ou legalizando a prostituição, os estados permitem a repedida violação de Direitos Humanos, da autonomia sexual

\footnotetext{
${ }^{50}$ Dados apresentados e disponibilizados pela Secretaria de Justiça e Defesa da Cidadania em palestra proferida na Universidade Católica de Santos (UNISANTOS), na data de 04/10/2013, por Executivo Público Ricardo Alves.
} 
e da dignidade. Toda prostituição é uma forma de escravidão sexual, e o tráfico é intrinsecamente ligado á prostituição. Por este ponto de vista, meios para erradicar o mercado do comercio sexual são simultaneamente os meios antitráfico e vice-versa. (Anderson e Davidson, 2002).

Por outro lado, existem as feministas que adotam uma perspectiva de direitos das trabalhadoras do sexo. Elas rejeitam a ideia de que a prostituição é intrinsecamente ou essencialmente degradante e encaram a prostituição como uma forma de trabalho, elas fazem uma grande distinção entre livre escolha da prostituição de adultos e todas as formas de prostituição forçada ou infantil. Este grupo entende que ações estatais que criminalizem a vontade individual de entrar para a prostituição é uma violação aos Direitos Humanos. Elas defendem a proteção para trabalhadoras da indústria do sexo, mas não desprezam o fato de existir um mercado para o comércio sexual em si, que deixa espaço para a exploração, incluindo o tráfico. (GRUPO DA VIDA, 2005; BLANCHETTE; DA SILVA, 2012). A solução para o problema reside na regulamentação do setor do sexo, como outros setores do emprego são regulamentados (ANDERSON; DAVIDSON, 2002).

Conhecer a política é fundamental, assim como conhecer todas as nuances que permeiam o fenômeno do tráfico de pessoas. Sem uma visão ampliada sobre a imigração e sobre o trabalho das profissionais do sexo, o profissional corre 0 risco de contribuir para a reprodução de preconceitos e estereótipos, além de favorecer a negativa de direitos. Proteger os indivíduos do tráfico de pessoas é mais que garantir-Ihes o direito à vida. É garantir também o direito à dignidade, 0 direito de ir e vir, o direito ao trabalho. E neste ponto as políticas de tráfico têm-se mostrado ineficientes quando desconsideram o anseio por mobilidade destes grupos e muitas vezes vêm o fenômeno principalmente pelo viés da migração irregular ou pelo viés unicamente da exploração sexual (quando muitas vezes o que se vê são mulheres exercendo o direito ao trabalho).

Essa reflexão é fundamental quando se discute a atuação dos profissionais do direito, uma vez que não se pode ignorar que o viés da repressão é muito mais plausível que o da garantia de direitos necessária para um acolhimento à vítima eficiente. Seja o imigrante que é vítima do tráfico, que se encontra no Brasil, seja 
a brasileira realmente vítima de tráfico e que se encontra fora do Brasil e para cá é trazida, a proteção a esses sujeitos muitas vezes é negada e muitas vezes são fatores que aumentam sua vulnerabilidade. Numa análise superficial, a atuação do profissional do Direito não se estende para além da repressão. O acolhimento à vítima é ação executiva e depende de disposição política e orçamento, sendo muitas vezes entendida como de competência da Assistência Social, mais que do Direito.

O tráfico de mulheres para fins de exploração sexual aparece em várias falas, em vários momentos não havendo distinção entre exploração para fins de exploração sexual e prostituição. A exploração sexual de travestis também teve relevo nas entrevistas. Para P5

Você deve ter estudado a parte histórica do tráfico de pessoas, sobre o tráfico de mulheres brancas, o tratado de Paris de 1859, tem uma lei da Inglaterra, normatizando... o primeiro perfil de vítima, e ainda é o mesmo, é o da prostituição. A prostituição é o que abre as portas. Atualmente a prostituição é comandada na Europa pela máfia russa. O tipo penal somente foi alterado para incluir os travestis, porque era fato atípico, porque eles são homens, então não havia crime. (P5)

O olhar que se tem acerca da prostituição feminina também apareceu na fala de P6

Eu tenho um posicionamento. É difícil a gente se posicionar, não como autoridade, um posicionamento como pessoa. Como mulher. Eu entendo que a mulher que foi se prostituir, o consentimento dela, não que ela deva ser incriminada, mas eu acho que a prostituição, ela diminui a condição feminina. Dessa perspectiva é que eu entendo que o verdadeiro feminismo deveria dizer não a prostituição. Eu não tenho que prá ganhar dinheiro vender o meu corpo colocando o gênero feminino inteiro numa situação de submissão em relação ao homem. "Ah, mas eu faço o que eu quiser como meu corpo..." Alto lá, porque não é assim, nós somos um grupo, e você é mulher, é um indivíduo, que venda outra coisa, mas não o seu corpo. (...) Eu tenho um posicionamento que é meu, porque o seu corpo ele é... é uma posição minha, uma posição pessoal, é particular. $O$ meu corpo ele é o habitat da minha liberdade, ele é o habitat da minha alma, e eu só sou livre porque sou um ser pensante que tem uma alma que mora nesse corpo. E se eu 
uma alma livre, pego esse corpo e escravizo ele, porque você não vai me dizer que as mulheres gostam... (P6)

O posicionamento do entrevistado, de caráter pessoal e não institucional, mostra-se em conflito com o posicionamento dos pesquisadores que entendem ser a prostituição um direito (ANDERSON e DAVIDSON, 2002; GRUO DAVIDA, 2005; MUSTO, 2009; BLANCHETTE, 2012; PISCITELLI, 2008 e 2012), mas está de acordo com os grupos feministas abolicionistas que entendem que a prostituição sempre será uma negativa à dignidade da mulher.

Esse ponto é bastante controverso, uma vez que de um lado temos as mulheres ou os travestis adultos, que escolhem a prostituição como profissão e que gostariam de ser respeitados no seu direito de escolher este caminho, de não serem vistos como vítimas do tráfico de pessoas. De outro lado, temos indivíduos que apesar de serem vítimas de tráfico, de terem sido enganados e diminuídos em sua dignidade, são encarados como sujeitos que consentiram e que por isso não seriam vítimas. Esse ponto merece atenção pelo fato da vítima de tráfico para fins de exploração sexual em muitos casos não ser vista como vítima, mas como um indivíduo que consentiu. É fundamental que o fenômeno seja olhado pelo prisma da exploração, é o que sugere a fala de P3

O desafio para investigar Tráfico de Pessoas é, a primeira coisa, desmontar o mito de que a vítima é criminosa. Fica um balaio, principalmente em crime sexual, de que a pessoa estava envolvida, de que não era vítima. A velha questão do consentimento. Aí você fala: não é isso, o problema é que ele está sendo explorado, é um ser humano explorando outro e é isso que é criminalizado. Esse é o desafio. Se você entrevistar as pessoas da especializada em Tráfico de Pessoas você vai ver como ele estão percebendo. (P3)

Apesar de na maioria das vezes os profissionais não fazerem distinção entre tráfico para fins de exploração sexual e prostituição, no relato de P2 a distinção aparece. A questão moral que envolve a prostituição e a atuação de igrejas no acolhimento à vítima também é objeto de reflexão no trecho que segue.

Eu lá em Brasília aprendi muita coisa com a ONG Da Vida, que são só profissionais do sexo. Elas falaram: quando você fala em prostituição, uma coisa é Tráfico de Pessoa, outra é a prostituição. Nem toda prostituta é traficada. E nem todo 
Tráfico de Pessoa é para prostituição. A prostituta tem todo o direito de fazer programa, o grande problema é quando ela é explorada pra isso e torna-se vítima do tráfico. Uma outra coisa que elas tem problema é a questão moral com relação à prostituição. Quando as organizações vêm ajudar as prostitutas, nesta perspectiva de exploração sexual para fins de tráfico, elas querem tirar as meninas da prostituição. Elas dizem que querem ser respeitadas, usar o próprio corpo, assim como qualquer pessoa. Prá muitas é uma escolha e elas devem ser respeitadas. Ela manda um recado para os movimentos de mulheres, movimentos feministas: "elas falam tanto em direito de escolha, nós também queremos ter nosso direito de escolha respeitado". Eu fui num congresso latinoamericano de igrejas, e as mulheres trabalham muito com prostitutas, e eu falei da necessidade de respeitar as pessoas, de tirar a questão moral, simplesmente ajudem, não queiram santificar ou demonizar. A prostituta já sofre porque é mulher, porque é prostituta, ela vai porque ela quer e muitas vezes o que acontece com ela é visto como acidente de consumo, um acidente da rota, um acidente de percurso, ela não vale nada... (P2)

O tráfico para fins de exploração sexual é apontado como abominável por P8, que faz também uma reflexão sobre o viés moralista com que a prostituição é tratada e da importância em se debater a proteção social do sujeito que fez a escolha em se prostituir.

Há atuação mais incisiva para a questão da exploração sexual, pelo viés moralista da questão. Eu não tenho posição resolvida acerca da questão da prostituição, seja masculina ou feminina, eu acho que é um dos pontos mais abomináveis que a gente pode pensar em exploração do trabalho, seja por fatores psicológicos seja por fatores de viver a margem da legalidade, eu só acho uma coisa: se você é prostituta e quer viver de fazer programa, você tem que ter proteção social. É a única coisa que eu tenho concretizado na minha cabeça. Mas eu acho que nessas situações elas são abordadas de forma muito moralista. Embora a gente tenha tantas entidades religiosas fazendo uma atuação ativa nos comitês, os religiosos são os que dominam um dos campos que são os mais importantes que é o de receber a vítima de Tráfico de Pessoas, mas num viés que é moralista, que é muito problemático. Ainda que eu não possa concordar, desconsidera a liberdade da mulher ou do homem que quer se prostituir, passa por um viés que é muito moralista. (P8) 
Se nas situações em que estão envolvidos adultos as polêmicas acima expostas sobre quem é e quem não é vítima, qual o peso do consentimento, quais os limites da liberdade de ir e vir e de trabalho parecem não ter fim, quando a exploração envolve crianças, não há dúvidas: estamos falando de uma prática criminosa. A exploração de crianças e adolescentes aparece na fala de P2.

Estão transportando meninas, de 10 a 13 anos, até 15, das cidades mais longínquas do nordeste até do interior de São Paulo ou de outros interiores aqui do Brasil, sob a alegação de que elas vão vir pra cá para terem uma vida melhor (relação madrinha-afilhada). Chegam aqui, essa criança vai cuidar de outras crianças, vai ser explorada para fazer todo o serviço doméstico. E uma forma de tráfico, porque ela foi engana, foi induzida a erro e ela chega aqui e está sendo explorada também. Você teve o deslocamento desta pessoa. Então mais uma vez a questão de gênero na perspectiva geracional está presente. (P2)

Quando perguntado sobre quais vítimas tem emergido dos debates e da prática, P6 pontua além da exploração sexual de crianças a exploração sexual de travestis como um principais focos.

Nos debates aparecem várias vítimas. Aparecem as vítimas de exploração sexual para o tráfico interno, crianças e adolescentes, a maior parte, que veem dos estados mais pobres, São Paulo é um grande destino para essas vítimas, que vão ser explorados sexualmente. Estão falando muito da questão dos travestis e transexuais, que eles veem e, enfim, vão ter seus corpos transformados. Eu não sei, até que ponto eles querem ter seus corpos transformados ou não tem outra opção, ou são conduzidos para essa realidade. Não estou dizendo da opção sexual, estou dizendo da transformação do corpo com silicone, por hormônio, enfim, agressões à matéria. Essas cirurgias plásticas que são bem modernas, bem contemporâneas. Isso tem surgido muito no debate. Pipoca um caso ou outro na prática. (P6)

Importante ressaltar que este foco na exploração sexual sobretudo de crianças e adolescentes aparece na Ata da Primeira Reunião de 2012 do Comitê Estadual Interinstitucional de Enfrentamento ao Tráfico de Pessoas realizada em 
13/04/2012 $2^{51}$, como proposta da Secretaria de Justiça e Defesa da Cidadania, conforme mencionamos na Categoria Vulnerabilidades.

Em algumas entrevistas os profissionais expõem que é muito comum a vítima não se ver como vítima. É o que se infere da fala de P5 e P6

A vítima é encarada como prostituta e a prostituta... é interessante: ela gosta do traficante, do cafetão, da cafetina. Isso aí é uma constante. Tanto que tem uma tecnologia num congresso que eu fui, prá gente não usar a expressão vítima, mas sim a expressão afetados pelo tráfico. Porque: as pessoas não se veem como vítima. Ela diz: eu vim porque quis... Esse querer, quando você está lidando com adolescente, como esta vontade se formou. Livre e espontaneamente? Ou foi a única opção, ou foi submetida a vício. (P5)

Mas, eles não tem consciência de que são vítimas, porque eles vieram de um lugar onde eles tinham menos oportunidade econômica. Eu vi na casa eles falando: aqui ainda assim é melhor do que na Bolívia, porque lá a gente não tinha nem o que comer. Aí o X que estava comigo disse: "mas olha, aqui eles tem só batata... não tem outra comida nesta casa." Mas tem batata! Se eu venho do deserto e não tem comida, se eu venho de um lugar em que não tem água e não tem comida e eu chego num lugar que tem comida, que tem alimento, que tem uma casa para eu morar, maravilha, eu não sou vítima. Mas aí, eles não se sentem vítimas, não acham que são vítimas. (P6)

A não percepção de serem vítimas do tráfico de pessoas aparece também em vários estudos sobre o tema.

Leal, Teresi e Duarte (2013) em pesquisa feita com mulheres que emigraram para Portugal e Espanha, relatam que as mulheres não se percebem como vítimas, não se sentem exploradas, não conheciam nenhum cafetão ou traficante de mulheres para o mercado do sexo. "Na maioria dos casos as mulheres se veem como enganadas, mas não se reconhecem como traficadas ou exploradas" (p. 106). Mas o discurso das mulheres mostra-se contraditório, quando relatam sentirem-se "humilhadas, perseguidas e vigiadas" (p. 107)

${ }^{51}$ Publicada no Diário Oficial do Estado, Poder Executivo, Seção I, pág. 15, edição 226. 
Teixeira (2008) em pesquisa feita na cidade de Uberaba - MG, traz esta reflexão sobre travestis que emigram para a Itália. Para a autora, a violência muitas vezes impede que os sujeitos se vejam como vítimas. Em outros momentos, os travestis concordam que assumiram uma responsabilidade em pagar pelos gastos de passagem, alimentação e hospedagem, entendendo ser legítima a cobrança.

No relatório do Reino Unido sobre o Plano de Ação contra o Tráfico de Pessoas de 2007 (SCOTTISH EXECUTIVE, 2007). Segundo o relatório a não identificação pode estar relacionada ao desconhecimento da vítima de que a situação em que se encontram, na verdade, constitui um crime contra elas próprias, ou elas foram submetidas a uma situação de exploração por um longo período que acabou levando a uma dependência psicológica com os exploradores.

Piscitelli (2008) traz relato de uma trabalhadora do sexo que migrou para a Espanha e que não se considera explorada ou traficada, e entende que "a dívida faz parte do processo migratório daqueles que, como ela, não tinham recursos para sair do país" (p. 56). Não considera que o valor que precisou pagar representou exploração ou se configurou como abusivo para as despesas de alojamento e comida. A autora problematiza que, apesar do relato, muitas vezes o não reconhecimento como vítima se deve ao medo de sofrerem represálias dos grupos criminosos, comungando com a ideia do relatório acima mencionado (SCOTTISH EXECUTIVE, 2007), de que sua não identificação como vítima se deve a terem criado uma dependência psicológica em razão do logo período de exploração e ainda por reconhecerem que a situação em que se encontram constitua crime contra elas mesmas.

Se em muitos casos os sujeitos não se veem como vítimas, em outros, considerando-se como tais têm receio de colaborar com a polícia por temer a organização criminosa que está por traz do tráfico. É o que se observa na fala de P3, que ressalta também a importância em, nas abordagens em postos de atendimento ser necessário um atendimento que não tenha caráter policial. 
Porque primeiro a vítima não se aceita, não se vê na qualidade de vítima. Segundo porque, se vitimada ela não quer colaborar com a polícia, porque por trás dela tem uma organização criminosa. Por isso, por exemplo, no posto avançado de atendimento aos migrantes no aeroporto de Guarulhos-Cumbica, não pode ter policial. É uma ONG ou a prefeitura que atualmente cuida. Se a polícia entrar tem que ser via elementos de inteligência, que não se apresentam como polícia, a não ser que estejam em uma diligência em que a polícia vai atuar mesmo e eles estão sabendo quem é quem. Essa é a percepção inicial. (P3)

A Comissão Europeia (EUROPEAN COMMISSION, 2004), sugere o uso do termo "pessoa supostamente traficada" (presumed trafficked person) para definir os indivíduos que parecem vítimas do tráfico de pessoas, em razão das pessoas traficadas inicialmente serem relutantes em se identificarem como traficadas. Segundo o relatório, a relutância das pessoas que foram traficadas em se autodeclaram vítimas se deve ao fato de temerem serem repreendidas pelas autoridades, resultando em uma mudança no seu status migratório e até mesmo expulsão do país em que se encontram.

Basseguio e Freire (2005) trazem esta reflexão com relação aos imigrantes bolivianos em São Paulo. Segundo eles, muitos dos bolivianos sequer imaginam estar sendo explorados, mas muitos têm medo de delatar seus patrões, além de preferirem trabalhar 17 horas no Brasil, que permanecerem desempregados na Bolívia.

Neste quadro, é muito difícil traças um perfil único, sobretudo tendo o Protocolo de Palermo e a Política Nacional posição consolidada no que tange ao consentimento. De um lado temos uma vítima que não se considera como tal, e de outro temos sujeitos considerados vítimas que de fato não são. Este descompasso muitas vezes leva a uma relativização dos direitos dos indivíduos que ora são considerados vítimas pelas políticas, ora são desprezados como tal e muitas vezes criminalizados por sua condição. $O$ tratamento dado a migrantes irregulares (indocumentados) e prostitutas, na maioria das vezes desconsidera sua real condição, sua autonomia e sua vulnerabilidade.

Este descompasso acima apresentado acaba fragilizando um sujeito já marcado por outras violações. Para P4, a vítima muitas vezes vê o tráfico como a 
redenção de uma vida de miséria ou de negação da identidade. Com isso, muitas vezes enxergam as redes de proteção como inimigas. A baixa autoestima aparece como um fator que favorece essa aceitação do tráfico como uma saída diante de uma vida insuportável e também faz com que a vítima não se veja como vítima.

Você vai enfrentar ao longo de sua jornada em Tráfico de Pessoas que muitas vezes a vítima ela te entende ou te compreende como um inimigo. Você estourou uma casa de prostituição, e agora, você vai fazer o que com a vítima? Como os bolivianos, quando eu estouro uma oficina de costura na estação da luz, você encontra outra vez com eles em Santo André, ganhando $R \$ 0,20,3,00$, mas é muito mais do que eles ganhariam em La Paz ou em outra cidade da Bolívia. Ou você encontra travestis do nordeste, muitas vezes, que, como que o pai vai admitir que o filho é uma travesti, naquele lugar machista do sertão, quem vai acolhelas lá? Nem o estado acolhe, então ela vem prá cá, e ela vem com gosto. Aqui ela encontra pessoas que protegem ela e encontra pessoas iguais a ela, o que elas fazem? Elas se unem. Aquele tráfico de pessoas prá elas foi o grande salvador, e a gente tá atrapalhando. Ou, a pessoa, para ela ser de alguma forma seduzida a participar desta rede, muitas vezes ela não vai por força, ela vai por gosto, porque ela quer. A autoestima dela é tão baixa que ela não se vê como vítima, ela vê o cara como um padrinho, um cara que favorece, um cara bonzinho. (P4)

Para P7, o mal estar com relação às redes de proteção pode ser minimizado com o esclarecimento às vitimas de que a intenção dos agentes é proteger seus direitos. Para o entrevistado o desconforto da vítima muitas vezes se relaciona ao fato de serem migrantes irregulares e por isso estarem numa situação migratória frágil.

Acho que a maioria, num primeiro momento ficam super desconfiados e receosos inclusive por eles mesmos, porque eles acham que eles mesmos estão fazendo coisas erradas. Principalmente pela questão migratória, mesmo que eles estejam regulares, mesmo os regulares ficam com medo de que esteja acontecendo alguma coisa. Mas depois que a gente explica porque a gente está lá, que estamos lá para proteger os direitos deles, eles são o objetivo principal, o bem estar deles e tudo o mais, depois de uma longa conversa eles começam a se abrir mais e acreditar um pouco em você. Muito nessa questão que eu te falei. Eles 
são muito submissos, eles confiam muito no dono da oficina e eles devem ouvir muita coisa do tipo, não confie em ninguém. O próprio dono da oficina deve dizer que se vier alguém não é para contar muita coisa, então num segundo momento, a maioria foi de gratidão: "que bom que vocês vieram", porque é uma realidade nova pra eles. A maioria não sabia que deveria receber 800,00 , sendo que recebiam 200,00 por mês. (P7)

Esta situação é favorecida por uma omissão dos agentes públicos que não facilitam 0 acesso dos migrantes às informações necessárias para a regularização de sua condição migratória. A falta de regularização atrapalha o acesso dos migrantes às políticas de saúde, educação, segurança.

Uma ação pioneira, relatada em (ALAMEIDA; NEDERSIGT, 2009), foi a parceria iniciada em 2004, realizada entre a Secretaria Nacional de Justiça (SNJ) e o Escritório das Nações Unidas contra Drogas e Crime (UNODC), no aeroporto internacional de São Paulo, em Guarulhos. A experiência teve início com uma ação voluntária da Associação Brasileira de Defesa da Mulher, da Infância e da Juventude (ASBRAD), que verificou a necessidade de desenvolver uma intervenção sistemática no contexto do aeroporto de Guarulhos para identificar e atender vítimas do tráfico de pessoas.

Foi iniciada uma articulação político-institucional para o estabelecimento do Posto de Atendimento Humanizado ao Migrante, no referido aeroporto, em dezembro de 2006, em caráter piloto. O referido serviço, com o apoio da organização holandesa Cordaid, atende brasileiros e brasileiras que retornam ao país na condição de deportados e/ ou não-admitidos, buscando identificar possíveis vítimas de tráfico com vista a encaminhá-los para a rede de retaguarda existente (ALMEIDA E NEDERSIGT, 2009, p. 4).

Um ponto que aparece com frequência é a forma como a vítima é aliciada. Parece unânime entre os entrevistados o entendimento de que há a atuação de uma rede de crime organizado por traz do tráfico de pessoas. É o que se infere da fala de P5, P1, P6 e P8.

Ninguém gasta 6 mil dólares, assim. Uma menina da Somália, onde ela vai arranjar 6 mil dólares? Nós fizemos a 
investigação, era um alemão, era uma rede, já sabe com quem, já se tem ciência de tudo. (P5)

Foi uma grande investigação que a gente fez na época, 2005-2006, em que tinha uma grande organização que enviava os brasileiros pra fora, enfim, mas e em toda esta dinâmica você tinha uma cadeia de situações de violência, que não estavam restritas única e tão somente a questão da pessoa ir para fora ilegalmente, porque você tinha naquele contexto a exploração ilegal do trabalho, você tinha naquele contexto a exploração pela prostituição, ali tinha o problema de uma grande quadrilha de fraudadores de Cartão de Crédito, enfim, tinha uma cadeia criminosa no entorno do fenômeno em si que deixou muito evidente as circunstancias e a maneira absolutamente em um primeiro momento fragmentada mas totalmente manipuladora de alguma coisa que transcende única e tão somente o ato de estar aliciando alguém. É como se fosse uma grande empresa que precisa de prestadores de serviço para viabilizar a atividade final que é exploração ou a remoção de órgãos, no caso ali era a exploração ilegal de mão de obra, tinha exploração sexual, mas enfim, mas que tinha todas estas ramificações com outras modalidades criminosas que demandavam ou exigiam essa estruturação, eram fundamentais para auxiliar ou permitir para que este crime fosse praticado. (P1)

E eu digo prá você e assino embaixo. Isso é uma máfia. É uma máfia que é difícil de combater porque você tem que dar opção para os explorados, então, onde é que a gente entrou nessa cadeia toda. A gente entrou como sociedade no sistema, produzindo pessoas que não tem condição econômica viável. O sistema produz uma necessidade de competição e de preços, e não dá uma viabilidade. Ao passo de que, quem quer... (...) Quem paga os impostos corretamente como eles tem que ser pagos, quem paga os salários honestamente como eles tem que ser pagos não tem condição de competir no mercado. (...) Eu acho que é uma leitura verdadeira, acho que este tráfico internacional de pessoas, visto como crime organizado ele tem vários vieses, várias facetas e fica mais claro na exploração sexual. (P6)

Não sei se existe uma máfia centralizada. Certamente não é centralizada. Existem redes próprias para dinâmicas próprias. Penso eu. Não existe uma conexão na dinâmica de tráfico de mulheres das filipinas para a indonésia com a da Hungria para a Holanda e do Brasil pra Espanha. Não acho que haja conexões. Não acho que estejam sob o mesmo controle, não acho que estejam centralizados. As dinâmicas de mercados proporcionam cada vez mais uma maior fragmentação disso e quanto mais fragmentado menos 
espaço de rastrear. Quando mais laço se cria, mais fácil de parar na teia. (P8)

O Relatório Final de Execução do I Plano Nacional de Enfrentamento ao Tráfico de Pessoas (RELATÓRIO FINAL, 2010) revela que no tráfico para fins de exploração sexual, geralmente os aliciadores são pessoas próximas às vítimas, como familiares, amigos ou colegas. Não se pode desprezar que quando se trata de crianças e adolescentes, muitas vezes o tráfico se dá por meio do rapto, sendo as vítimas presas e drogadas. Em outros casos, são enganadas com promessas vãs.

O aliciamento promovido por indivíduos próximos aparece na fala de P6, para quem além das redes de crime organizado que movimentam o tráfico de pessoas, existem também redes locais, que constroem um fluxo muito eficiente de exploração

\begin{abstract}
Eu vi outro dia um sociólogo, numa palestra no Cáritas, falando sobre as populações do vale do Jequitinhonha, que acabaram migrando e sendo escravizadas na Europa, via, Teófilo Otoni. (...) O que fez estas populações migrarem, porque passa por Teófilo Otoni? Porque se fez de fato uma rede de aliciadores ali. Um arrumou o emprego... e foi fazendo a rede. (...) Uma vez fixados ali, era como uma agência de turismo. $E$ as pessoas sabem que indo ali elas conseguem ir para o exterior. $O$ que elas não sabem, é o que as espera lá. Porque os que voltam, ou volta aliciador ou são pessoas que realmente encontraram um trabalho honesto. Mas tem os que não voltam, que foram mortos lá. Que ficaram escravizados lá. Então esta história não volta. E o fluxo de pessoas continua acontecendo. (P6)
\end{abstract}

$\mathrm{Na}$ pesquisa feita por Leal, Teresi e Duarte (2013) também pode-se verificar a proximidade entre as pessoas que são levadas para o exterior e quem as leva. Muitas foram envolvidas até mesmo por meio de contatos telefônicos ou pela internet.

Gueraldi e Dias (2012) e Torres (2012), trazem uma relação de redes de indivíduos e organizações que atuam no aliciamento de pessoas. São eles: redes de entretenimento, como shopping centers, boates, bares, restaurantes, etc.; redes de mercado da moda; redes de agências de empregos; redes de agências 
de casamento; redes de telessexo; redes da indústria do turismo e redes de agenciamento para projetos de desenvolvimento e infraestrutura.

Para P3, a vítima tem um papel muito importante na investigação de qualquer caso. Para o entrevistado o tratamento da vítima é fundamental para que ela colabore e o que se vê na prática é que a vítima muitas vezes é tratada com hostilidade

A vítima para nós, polícia judiciária (polícia judiciária é aquela que investiga o crime depois que ele aconteceu para levar o autor às barbas do judiciário), para nós, na nossa visão a vítima tem que colaborar com a investigação. Essa é a vítima prá nós. A boa vítima é a que não perturba o serviço da autoridade. Ela tem que ser compreendida, porque chega nervosa, mas tem que dar algum tipo de colaboração e que me ajude a investigar o crime também. Você encontra vítimas antipáticas, vítimas reticentes, vítimas traumatizadas, todo tipo de vítima, e uma obrigação que temos pelo artigo 6 o do CPP é ouvir o ofendido é trazer a versão dele. A vítima colaboraria muito mais, se bem tratada, se encaminhada pra outras coisas, ela vai voltar, vai lembrar, ela não pode ser tratada com hostilidade. As pessoas falam em criminalizadas, mas eu acho que tem mais a ver com hostilidade. Acaba tendo o mesmo tratamento para o autor, para a vítima, para a testemunha, todo mundo é suspeito. (P3)

A fala do entrevistado apresenta uma contradição: a vítima deveria ser bem tratada não em respeito à sua condição ou em respeito à dignidade humana, mas sim para que colabore com a investigação. Essa desatenção com a vítima aparece também no II Plano Nacional de Enfrentamento ao Tráfico de Pessoas, que no que se refere à vítima-testemunha, somente o que se propõe é que esta faça parte do programa de proteção à testemunha, sem nenhum cuidado para que não haja uma revitimização da mesma.

Não é o que se observa Diretiva no 36/2011 da União Europeia (UNIÃO EUROPEIA, 2011). Pela Diretiva, "o sucesso da investigação e da ação penal nas infracções de tráfico de seres humanos, a instauração do processo não deverá depender, em princípio, de queixa ou de acusação por parte da vítima" (item 15). Além disso, 
As vítimas de tráfico que já sofreram os abusos e tratamentos degradantes habitualmente associados ao tráfico, como a exploração sexual, os abusos sexuais, a violação, práticas escravagistas ou remoção de órgãos, deverão ser protegidas da vitimização secundária e de novos traumas durante 0 processo penal. A repetição desnecessária de inquirições durante a investigação, o inquérito e a instrução, e o julgamento deverá ser evitada, por exemplo, se for caso disso, mediante a gravação em vídeo dessas inquirições numa fase inicial do processo (item 20).

Entendemos ser o cuidado com a vítima a faceta mais importante da política de enfrentamento ao tráfico de pessoas, por entendermos ser uma política em Direitos Humanos. A ênfase no viés repressivo muitas vezes afeta a vítima, negando a ela o reconhecimento de seus direitos.

A criminalização da vítima aparece na fala de P2. Para este entrevistado o tráfico de pessoas muitas vezes leva o indivíduo da posição de vítima para a posição de réu. Essa mudança de papéis muitas vezes acontece na própria lógica da rede criminosa, em que a vítima acaba sendo obrigada a traficar drogas, por exemplo. Isso faz com que aquela pessoa que deveria ser tratada como vítima seja tratada como criminosa.

Você tem esta mulher em uma situação vulnerável, que ela vai ou para o Tráfico de Pessoas e dentro do Tráfico de Pessoas ela vai ser usada para ser mula, para ser traficante de drogas. Então ela vai estar aqui no Tráfico de Pessoas e como resultado, se esta rede for desbaratada e esta mulher estiver lá na condição de vítima e depois de traficante, a única coisa que não vão ver é que esta mulher é primeiramente uma vítima. Então, se ela for vista como traficante, você vai ter outro resultado que esta mulher vai ser uma mulher encarcerada no futuro. (P2)

A acima referida Diretiva no $=36 / 2011$ da União Europeia (UNIÃO EUROPEIA, 2011), trata entre outras questões da proteção das vítimas. Segundo a Diretiva,

as vítimas de tráfico de seres humanos deverão, ao abrigo dos princípios fundamentais das ordens jurídicas dos Estados-Membros em causa, ser protegidas da instauração de uma ação penal ou da aplicação de sanções em consequência de atividades criminosas, tais como a utilização de documentos falsos ou a violação da legislação 
relativa à prostituição ou à imigração, em que tenham sido obrigadas a participar como consequência direta de serem objeto de tráfico. O objetivo desta proteção é salvaguardar os direitos humanos das vítimas, evitar uma vitimização adicional e encorajá-las a testemunhar nos processos penais contra os autores dos crimes. Esta salvaguarda não exclui a ação penal ou a punição das infracções quando alguém voluntariamente tiver cometido essas infrações ou nelas participado (UNIÃO EUROPEIA, 2011, p. 3, item 14).

Tanto a Política quanto os dois Planos Nacionais de Enfrentamento ao Tráfico de Pessoas não contemplam previsão semelhante. O II Plano Nacional de Enfrentamento ao Tráfico de Pessoas, atualmente em vigor, no que tange à atenção à vítima, foca a atuação na integração e fortalecimento das políticas públicas e redes de atendimentos, de maneira direta, e capacitação, produção e disseminação de conhecimento e informação sobre o tráfico de pessoas. O plano não assumiu uma postura radical de proteção e descriminalização das vítimas, como feito pela União Europeia.

Outro dado apresentado é a grande participação de mulheres como aliciadoras nas redes criminosas. Isso aparece na fala de P3 e P2.

Relatório do UNODC 2009 conclui que a mulher delinquente tem participação significativa no tráfico de pessoas, uma porcentagem expressiva de traficantes é de mulheres que traficam mulheres para exploração sexual. (P3)

E a gente muitas vezes deixa de ter este olhar. Por exemplo, as mulheres estão sendo mais arregimentadas para atuar nas redes de aliciamento, este é um outro fenômeno também. Por que a mulher? Porque ela é mais confiável. (P2)

Essa presença da mulher como aliciadora, principalmente no tráfico para fins de exploração sexual é verificada também em Torres, (2012), Gueraldi e Dias (2012), Leal, Teresi e Duarte (2013). Referidos autores também ressaltam o fato das mesmas serem mais confiáveis.

Para alguns profissionais é importante um olhar atento para o consumidor do tráfico de pessoas. É o que pensa $\mathrm{P} 4$ no que se refere ao tráfico para fins de exploração sexual e para exploração do trabalho 
E o que me preocupa e é algo que deve ser muito bem pensado, não é só na vítima e no aliciador, mas principalmente naquele que consome. Porque se a gente falar em tráfico de armas, em tráfico de drogas sem consumidor, é um mercado falido. Da mesma forma se a gente pensar no Tráfico de Pessoas como o segundo tráfico mais rentável, me preocupa aqueles que estão consumindo. "Quero uma loura, alta, magra, ou assim ou assado". (...) Hoje, eu vou dizer que a gente acaba de alguma forma atrapalhando o mercado, então se a gente invade uma oficina de costura a gente consegue atrapalhar ali aquele comércio, acaba de alguma forma salvando algumas vidas, mas quem consome está longe de ser o foco das ações. (P4)

consumidor do tráfico para exploração do trabalho é analisado também por P6

O meu posicionamento: eu sou contra a gente responsabilizar criminalmente essa pessoa (o boliviano que está com a família), porque seria como criminalizar o vaporzinho das drogas, mas que nunca diminuiu o tráfico. Ele acaba sendo uma vítima mesmo e se é um processo novo que a gente pode ter esse olhar, que seja assim... a gente tem que pegar quem está mais em cima da cadeia, quem contrata o serviço auferindo lucro desse processo todo. Essa pessoa, ela explora esses daqui indiretamente agora, ela explora indiretamente, ela não paga imposto pro governo. Ela ganha prá cá, ganha prá lá e prejudica o país. $\dot{E}$ isso que eu consegui notar e a gente precisa bolar estratégias já. (P6)

A ideia da exploração pelo viés do consumidor é fundamental quando se deseja promover uma análise sobre o tráfico como um bom negócio. Só há tráfico, de qualquer ordem, porque há demanda para consumir o "objeto" traficado. Para Anderson e Davidson (2002) explorar a demanda do tráfico não é só inquirir sobre os indivíduos que exploram ou consomem o trabalho/serviço de tráfico de pessoas, mas também questionar o que os estados tem feito - ações e omissões - construindo condições para que seja possível e rentável consumir ou explorar tais trabalhos.

Um estado que se omite ou que em suas ações acaba por fragilizar ainda mais as vítimas (ou possíveis vítimas). E a ambição do mercado por "novos produtos" não tem fim: exploração sexual, exploração para o trabalho, para o 
tráfico de órgãos, para fins de adoção, para fins desportivos. Onde houver procura, haverá oferta. É a lei do mercado. A variedade de vítimas, ou de mercadorias, aparece na fala de vários entrevistados.

O tráfico de órgãos é objeto de reflexão por parte de P4

Mas você vê: alguém já viu milionário em fila de transplante para doação de órgão? Para mim a mais pavorosa das formas é o tráfico para fins de remoção de órgãos. É o mais silencioso e clandestino de todos. Teve um caso aqui em Taubaté, envolvendo médicos. Tive alguns casos de máfias

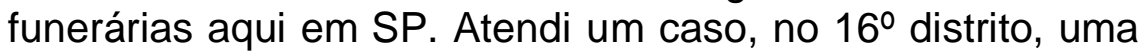
médica no Hospital SP que queria forçar a mãe, que estava em trabalho de parto, o filho estava com morte encefálica, a médica fazendo escândalo com a mãe querendo forçar ela a assinar uma doação de órgãos. Em Mairiporã já teve um caso de necrotério com córneas. Mas mesmo assim, é um ou outro caso. (P4)

O tráfico para fins de adoção aparece na fala de P5, para quem a mulher que quer ser mãe a qualquer custo chega às vias do irracional.

E tem o tráfico para fins de adoção, que é pequeno, mas existe. Porque quando se chega na parte da adoção, você lida com a coisa mais irracional que a mulher pode trazer, a vontade de ser mãe. A mulher pode ser pós doutorada em Harvard ou ser uma lavadeira, são iguais, se tiver que praticar todos os crimes, ela comete. Elas veem e falam na minha frente: dane-se a lei. Caem no discurso do irracional. O discurso do irracional não vê que onde se leva uma criança, se leva drogas, armas, prostitutas, e ignora por completo. (P5)

Outra forma de exploração apontada por P5 é o tráfico de meninos para fins desportivos.

Tem uma modalidade que é para jogar em times de futebol, tráfico para fins desportivos. O caso mais famoso foi na Portuguesa Santista. Essa vítima ela ainda gosta do traficante, então ela não colabora, ela inventa, ela mente, ela deixa todo mundo nervoso, e quando você tenta... O fluxo da infância não é o mesmo fluxo do adulto. Voce não pode pegar pesado como com o adulto. Adolescente tem que agir de outro jeito. (P5) 
A vítima de Tráfico de Pessoas, ainda que a gente generalize, a vítima de Tráfico de Pessoas talvez seja uma mistura dos mais diversos tipos de pessoas, dos mais diversos tipos de explorados, eu acho importante que a gente tenha essa consciência. (P8) 


\section{5 - Categoria 5 - Articulações - Os eixos temáticos e a intersetorialidade da política}

Um olhar multidisciplinar apareceu como uma demanda em vários momentos das entrevistas. Articular políticas, articular saberes e articular fazeres são apontados como necessário e como uma falha nas políticas em Direitos Humanos e especificamente na Política de Enfrentamento ao Tráfico de Pessoas. Muitas vezes a temática Direitos Humanos é apresentada como muito fechada.

Os eixos temáticos da Política de Enfrentamento ao Tráfico de Pessoas prevenção, repressão e acolhimento à vítima - exigem esse tratamento articulado, para não parecer que são várias políticas. O diálogo entre os gestores da política é fundamental para que ela seja efetiva.

$\mathrm{Na}$ categoria "Eixos Temáticos e Articulação das Ações - Leitura Multidisciplinar" propusemos uma análise sobre a necessidade da Política de Enfrentamento ao Tráfico de Pessoas atuar de forma articulada, seja com outras políticas, seja com outros entes federados, seja uma articulação entre os profissionais que compõem a rede de proteção.

Essa colocação permite uma reflexão acerca da necessidade de serem os Direitos Humanos tratados de maneira transversal e não como uma política estanque. Os princípios e valores dos Direitos Humanos devem permear todas as políticas. Enquanto isso não for uma realidade, as políticas dividirão os sujeitos titulares de Direitos Humanos, o que contribui para a falta de acolhimento dos direitos em razão do afastamento provocado pela não identificação com determinados grupos.

Encontramos nessa categoria um tema que possui pontos de encontro recorrentes, formando um núcleo comum das impressões dos entrevistados. Trata-se das falas sobre a descontinuidade e desarticulação da política de enfrentamento ao tráfico de pessoas, apontadas como fatores que dificultam a efetividade da política. Por terem aparecido de modo incisivo e referirem-se a um tema comum, optamos por apresentar primeiro as falas dos entrevistados para 
depois fazermos uma análise genérica sobre o assunto, mudando o padrão da apresentação e análise dos dados até aqui exposto.

A descontinuidade das políticas é apontada como fator que dificulta sua efetividade. É o que expõe P4 quando perguntado sobre o que veria como empecilho para a implementação das políticas públicas em direitos humanos.

Eu acho que é continuidade. Eu acho que no Brasil, não só em matéria de Direitos Humanos, a gente tem uma ausência de continuidade. Infelizmente a gente tem, pelos órgãos públicos, ausência de continuidade, ou seja, ainda veem alguns programas como sendo de governo e não de estado. E aí essa não continuidade faz com que o assunto e as ações percam força e a gente tem um sucateamento do que já existia e uma não continuidade. Eu acho assim: se a gente tinha bons programas, boas ações, elas deveriam, pela sociedade civil serem enaltecidas e serem cobradas para que permaneçam existindo, com a perspectiva de aumento das ações e de empoderamento das ações já existentes, mas o que a gente vê ocorrendo, principalmente em matéria de Direitos Humanos, é que acaba, ou por vaidade, ou por qualquer outro motivo, esta continuidade. Acho que o grande desafio é este. (P4)

À descontinuidade das políticas P5 alia as mudanças constantes de parceiros como um fator que dificulta a efetividade das ações.

Você tem que decifrar estes totens, explicar.É um trabalho complicado, porque os parceiros mudam muito, e o judiciário é muito fixo, é muito perene. Os outros não. Os outros estão sempre rodando e toda a rede que a gente faz, amanhã desaparece, se destrói. O que está faltando para os Direitos Humanos aqui no Brasil é a perenidade e a harmonia do discurso com a prática. Tendo esses dois... e os dois estão muito vinculados ao estado de direito. Se eu passar um ano com os mesmos interlocutores eu já estou feliz, eu não consigo. (...) Eu vou falar com Brasília e cada hora é uma pessoa diferente. A criança e o adolescente é perene. Não o interlocutor em Brasília. A política anterior desaparece. É a política de estado: terra arrasada sempre. Em todas as esferas. No judiciário não tem isso. Imagine se um juiz saísse e mandasse queimar todos os processos... (P5)

A descontinuidade das políticas, a sua desconstrução e a falta de comprometimento institucional aparecem na fala de P2 como uma grande falha 
nas políticas em direitos humanos de uma maneira geral e na política de enfrentamento ao tráfico de pessoas de forma específica.

Deu mais do que uma amornada. O que aconteceu aqui no estado de São Paulo parece um reflexo, reflete-se em outras realidades. Salvador tá passando pela mesma situação. Desconstrução. Fechou, ninguém mais, parece que colocam um indivíduo chave quando eu quero desconstruir tudo. Parece que aconteceu isso aqui em SP, em Salvador, em outras cidades... parece que está agonizando. Por quê? Se esta temática fosse institucionalizada e não fosse somente as pessoas de bom vontade que estão nas pontas das instituições, mas se as instituições assumissem esta bandeira, seria diferente. Porque quando você tirasse aquela pessoa que está ali, a instituição teria que manter a ideia. (...) Mas, quando você não se compromete, quando o estado não incorpora para si isso enquanto política pública, aí a gente vai voltar na questão da política pública. Você tem isso, só se faz se houver vontade política daquele agente que está naquele momento político conveniente para ele ali, se não tem, ele muda seu panorama e diz que agora não quer isso, não quer Tráfico de Pessoas e vai tratar da questão de quilombolas, ou LGBTT. (P2)

A falta de comprometimento institucional é também apontada por P7 como uma dificuldade para a efetividade da política. Para o entrevistado, o comprometimento pessoal é que acaba levando ao comprometimento institucional

Voltando à nossa listinha do porque as coisas funcionam ou não funcionam é: comprometimento institucional e pessoal, então a gente tinha que colocar os dois, que envolve uma questão de capacitação, talvez até uma sensibilização, porque eu acho que a sensibilização vem antes da capacitação. A pessoa que está sensibilizada tem 0 interesse em ser capacitada. A pessoa às vezes recebe informação mas não está sensibilizada, então esquece. (...) Entender porque a vítima veio, porque ela está aqui, porque que ela tem que ser tratada desse jeito. (...) Então, primeiro o comprometimento institucional, pessoal. (...) Tipo assim, isso aqui não me interessa, vou engavetar, isso aqui não me dá visibilidade política. Nesse sentido também eu vejo e assim, mesmo para quem quer fazer tudo isso, mesmo prá quem tem comprometimento institucional, quem tem comprometimento pessoal, quem não tem nenhum problema com a corrupção, falta de organização. A gente não sabe como se organizar. Como a gente pode fazer um relatório? Eu juro, não sei. (P7) 
A falta de comprometimento institucional aparece também no descaso com os Direitos Humanos. Incorporar os Direitos Humanos como um valor dentro das instituições é ponto importante para que o comprometimento se dê. Para P3

\begin{abstract}
O primeiro desafio é conviver internamente com os Direitos Humanos. Você vai defender Direitos Humanos muita gente vai dizer: é alienado, você vai virar minoria dentro a instituição. Porque ainda há uma cultura de que isso é secundário, há um senso comum que permeia as instituições policiais de que esta história de Direitos Humanos é aquele discurso perverso de que só bandido tem direitos humanos. Não entende o que são Direitos Humanos. (...) Então num primeiro momento é a barreira interna. (...) Se a autoridades é perversa e cultua desvalores, como é que os agentes de autoridade vão se comportar, porque na hierarquia não conseguem se insurgir. (...) Vencer a barreira interna. (P3)
\end{abstract}

A falta de articulação, de comunicação entre os vários órgãos da política também é apontada como limitadora. A desejável rede de atendimento ainda aparece como um ideal. Na fala de P7

O que eu quero dizer é o seguinte: falta organização, falta comunicação, falta articulação. Porque que a PF não conversa com a defensoria e fala: Defensoria, a gente vai encaminhar prá vocês todos os casos. Então encaminha! Fala que o horário de atendimento é tal, porque que a gente teve a reunião com o consulado e porque que isso não foi prá frente também. Tudo bem, a gente não pode influenciar em questões diplomáticas, mas a defensoria tem uma atuação coletiva também, pode entrar com ações civil públicas, falta defensor. Mas eu acho que a falta de estrutura e de pessoal não pode ser desculpa prá tudo também. Como eu te falei: o interesse institucional pode servir de manobra prá tudo isso, pode conseguir que de alguma forma, mesmo que minimamente, fazer essa máquina andar. A gente fez um fluxo de atendimento no comitê, que ficou muito bom, muito completo e ficou até um pouco complexo. (...) Porque a PC não sabe o que a defensoria estadual faz. $E$ a defensoria pública federal não sabe o que o MP faz. (P7)

A desarticulação aparece também na fala de P5, que ainda expõe brechas na política no que tange ao tratamento do traficante

Teve um traficante que pediu refúgio, foi negado, mas ele está aqui. Quando um traficante pede refúgio, quando se diz não, o que aconteceria no estado de direito: expulsa-se. 
Aqui não, aqui o cara fica, não tem dinheiro para pagar. $\mathrm{O}$ Brasil não está numa economia legal não paga. Formalmente o cara é objeto de expulsão, na prática ele fica. Teve um traficante que a polícia francesa me deu até o endereço dele, lá no Ipiranga. (...) As políticas são totalmente desarticuladas, não são perenes. Nestes comitês, a pessoa ia lá porque não ficava bem a instituição não mandar ninguém, mas ela não estava nem aí prá nada. (P5)

A falta de vontade política e o comprometimento com grandes grupos econômicos aparece como empecilho para a concretização da política de enfrentamento ao tráfico de seres humanos.

São diversos fatores, fatores que são complexos, mas eu coloco novamente em balizas que são econômicas. Eu acho que em grande parte não há uma ação incisiva por parte do poder público. (...) Pensar em romper com uma lógica de opressão e de exploração, gera uma repercussão muito alta para si, repercussões muito altas para o plantio da cana, gera repercussões muito altas para o plantio da soja, gera repercussões muito altas no plantio da laranja. Setores que são, quando penso no estado de São Paulo, centrais na organização econômica, na organização produtiva daqui... eu acho que falta disposição política de peitar essas pessoas. Peitar um grande produtor de laranja, de suco que financiou a sua campanha? Você não vai fazer isso, é uma falta de disposição política propriamente, de fazer isso. Ainda que haja boa vontade por parte de governo federal, se não tiver incisão no estado, se não tiver política local, o negócio não anda. E se ficar nesse negócio de igrejeiro dar abrigo e acadêmico fazendo artigo, o negócio também não vai andar. Eu acho que só política faz andar. Um trabalho efetivo com as pessoas, ter um trabalho de inclusão dessas pessoas, porque eu acho que a inclusão política dessas pessoas é o primeiro passo. (P8)

É interessante observar que toda a descontinuidade e o descomprometimento institucional apontados pelos entrevistados contrariam a própria estrutura da política de enfrentamento ao tráfico de pessoas e mesmo das políticas públicas em geral. É da essência das políticas públicas a articulação entre os diversos setores da sociedade, sendo entendida como ponto fulcral tanto pela Política Nacional de Enfrentamento ao Tráfico de Pessoas (MINISTÉRIO DA JUSTIÇA, 2007), quanto pelos I e II Planos Nacionais de Enfrentamento ao Tráfico de Pessoas. 
Na Política Nacional de Enfrentamento ao Tráfico de Pessoas a articulação aparece nas diretrizes gerais e específicas. Como diretrizes gerais a articulação de todas as esferas do governo é proposta para o fortalecimento do pacto federativo; a articulação também é sugerida entre as organizações não governamentais nacionais e internacionais; ainda há a o incentivo à participação da sociedade civil em instâncias de controle social das políticas públicas e o incentivo à participação dos órgãos de classe e conselhos profissionais na discussão sobre tráfico de pessoas ${ }^{52}$.

Como diretrizes específicas, apontamos as previstas no eixo de prevenção ao tráfico de pessoas. A integralidade e a intersetorialidade nas áreas de saúde, educação, trabalho, segurança, justiça, turismo, assistência social, desenvolvimento rural, esportes, comunicação, cultura, direitos humanos, dentre outras é proposta (o que pressupõe a articulação entre as diversas políticas), bem como a mobilização e fortalecimento da sociedade civil, mostram a importância da articulação.

É necessário pontuar que a sociedade civil tem-se mostrado fundamental na elaboração e continuidade das políticas públicas, seja por meio da atuação de movimentos sociais que levam ao estado e expõem à opinião pública a necessidade de atendimento de suas demandas, seja por meio da imprensa que expõe falhas e virtudes na realização das políticas públicas, seja pela atuação das organizações não governamentais (PEREZ, 2006). "Na prática, o que ocorre e que derrubados os muros altos que separavam a Administração Pública da sociedade, esta passa a participar da concepção, da decisão e da implementação das políticas públicas" (PEREZ, 2006, p. 171). A importância da participação da sociedade civil também é apontada por Aith (2006).

A falta de continuidade apontada pelos entrevistados aparece como ruptura do pacto federativo, quando os Estados não aderem à Política Nacional, e também quando entendem que a Política aparece como uma política de governo, e não de Estado. Na introdução do I Plano Nacional de Enfretamento ao Tráfico de Pessoas, a Política Nacional é apresentada como Política de Estado:

\footnotetext{
52 Política Nacional de Enfrentamento ao Tráfico de Pessoas, Anexo do Decreto 5948, de 26/10/2006, art. 4 ㅇ, I, III, IX, XI, XII.
} 
Pelo fato de ser o tráfico de pessoas um tema afeto a diversas áreas, como saúde, justiça, educação, trabalho, assistência social, turismo, entre outros, seu processo de construção envolveu diversos ministérios, demonstrando que o assunto é uma política de Estado, com ações incluídas em suas mais diversas áreas (BRASIL, 2008, p. 7 - grifo nosso).

Aith (2006), em texto que diferencia políticas de Estado de políticas de Governo, aponta que "a política de Estado pode se diferenciar da política de governo, na medida em que uma política de Estado exige uma continuidade, deve ser perene e não pode ser quebrada ao sabor da troca de governantes" (AITH, 2006, p. 237). Neste sentido é que interpretamos a fala dos entrevistados, que entendem ser necessária uma atitude perene para que a política não se perca nas trocas de governo e com isso não perca a continuidade e s ganhos construídos nas articulações.

Mas, infelizmente, pelo volume de falas que problematizam a descontinuidade das políticas, a constante mudança de parceiros, a desconstrução da política, a falta de comprometimento institucional, a falta de articulação e a falta de vontade política, desarticulação, acreditamos que haja substanciais brechas na execução da Política e dos Planos de Enfrentamento ao Tráfico de Pessoas. Essa desarticulação é encontrada não somente nas políticas contra o tráfico, mas nas políticas de direitos humanos em geral.

A temática dos Direitos Humanos é apresentada como fechada. Cada política cuida de seus interesses e muitas vezes não se abrem a outras pautas. $A$ importância da interlocução da Política de Enfrentamento ao Tráfico de Pessoas com outras pautas é ressaltada por P2, que acredita que o tema deva fazer parte de outras agendas para ganhar maior visibilidade e efetividade.

Então, o nosso grande trabalho é tirar a temática para além dos muros daqueles que com ela tratam, da área de Direitos Humanos. O desafio é (...) exatamente dar visibilidade e colocar em outras pautas, em outros movimentos e agendas a temática do Tráfico de Pessoas, para além daqueles que tratam com ela. Este seminário ${ }^{53}$ vai ter esta função, este objetivo principal. Nós vamos debater, pela primeira vez, dar

\footnotetext{
${ }^{53}$ Seminário realizado em 2012, junto com o Conselho de Direitos da Mulher, tratando da temática Tráfico de Pessoas.
} 
visibilidade, compartilhar a temática com: movimento LGBTT, movimento negro, movimento da juventude e movimento de mulheres e feministas. Já fizemos com as centrais de trabalhadores, mais especificamente com as centrais das trabalhadoras. Já fizemos com algumas lideranças de movimentos de mulheres, e agora vamos reunir todos pra tratar disso. E o objetivo também é fazer com que a cidade de São Paulo tenha um olhar mais específico para delinear daqui prá frente que políticas públicas irá desenvolver para enfrentar e acolher as vítimas do Tráfico de Pessoas. (P2)

Essa interlocução passa pelo reconhecimento de que vários são os atores que devem estar envolvidos nesse processo, incluindo agentes públicos e membros de movimentos sociais. Para P2

Eu creio que a situação ela não será resolvida apenas do ponto de vista legal, logicamente que não. Você tem um conjunto de atores neste processo que são assistentes sociais, médicos, educadores, profissionais da saúde e ativistas ou militantes dos movimentos sociais, que eles são os porta vozes e os protagonistas desta situação. São eles que estão na ponta. (P2)

Para que a atuação destes agentes tenha um resultado efetivo, deve haver uma articulação eficiente do poder público. A articulação deve abranger os três eixos de atuação da política de enfrentamento - prevenção, repressão e acolhimento à vítima. Ocorre que essa atuação pode ser definida em razão da própria posição da política no organograma do Estado. É o que diz P7.

Por exemplo, tem lugares que está vinculado à secretaria de segurança pública, então fica mais com aquela vertente de repressão, o atendimento à vítima parece menos prioritário. As secretarias de governo se organizam de forma diferente (...) Eles estão tentando padronizar, mas fica meio complicado mesmo. É uma ingerência que não tem, do governo federal sobre a organização do governo estadual. É complicado. Eles tem que criar, mas de que forma, ligada a que secretaria, é meio complicado. (P7)

Reflexão sobre a posição da política no Estado é trazida também por P6.

Núcleo está na Secretaria da Justiça. A Secretaria da Justiça não tem verba, não tem parte de assistência. Então, o Núcleo só tem a capacidade de articulação, ele não tem a capacidade de agir.(...) Então, eu vejo assim: existe uma 
preocupação no discurso, existe um começo de conscientização de que não são números falsos, que de fato existe, mas, ainda não existem meios reais e práticos fornecidos pelo Estado, tanto que tudo que se consegue é através das organizações não governamentais, é através de articulação, mas isso não é institucionalizado. (P6)

E uma coisa eu digo: está no estado, na secretaria da justiça, não está na secretaria de assistência social. A secretaria da justiça não tem assistente social, os assistentes sociais não estão querendo trabalhar nessa questão com maior profundidade, porque o problema é da secretaria da justiça. Então, quem faz? Aquele que tem o papel de articulação não tem verba, a verba é pequena, não tem como articular quase nada. Ele tem que se organizar prá conseguir execução. Aí eu penso: ou se muda tudo isso, mas isso não está na nossa mão, mas do ponto de vista de quem vai escrever um trabalho, você pode escrever para mudar tudo isso. Quem está trabalhando com a mão na massa, você tem que trabalhar com o que você tem. (P6)

É importante frisar que cabe à Unidade Federada definir qual secretaria será responsável pela implantação da política. Cada Estado tem autonomia para esta definição, mesmo porque, a organização das secretarias também é prerrogativa $s$ dos Estados. Deste modo, não é possível que seja definida uma secretaria, a priori, como responsável. Dos 16 estados que possuem Núcleos de Enfrentamento ao Tráfico de Pessoas, oito deles está vinculado à Secretaria de Justiça e Direitos Humanos ou Secretaria de Justiça e Defesa da Cidadania (é o caso dos Estados do Acre, Amazonas, Bahia, Ceará, Distrito Federal, Pará, Paraná e São Paulo), dois Estados vinculam a política à Secretaria de Políticas para Mulher (Alagoas e Goiás), dois Estados vinculam à Secretaria de Justiça e Segurança Pública, dois à secretaria de Assistência Social e dois à Secretaria de Defesa Social e Prevenção da Criminalidade.

Não fizemos uma análise das atribuições de cada uma dessas secretarias, mas o que queremos ressaltar é que entendemos que o posicionamento da política dentro do organograma do Estado não deve ser um empecilho para o bom andamento da política. Mais uma vez ressaltamos a importância de serem as políticas públicas construídas de modo a garantirem que os propósitos a serem alcançados não dependam de boa vontade ou de afinidade com o órgão gestor. A fala dos entrevistados, no entanto, vincula mais uma vez a atuação da política a 
um viés pessoal em detrimento do caráter institucional que deveria ser priorizado pela política. A desarticulação da política acaba segmentando a mesma: papel da justiça, papel da assistência social, papel da segurança pública.

Essa segmentação e a pessoalização da política aparece na fala de P5. Para o entrevistado, a assistência acaba ficando a cargo de organizações não governamentais e essa articulação focada nas ONGs muitas vezes é pessoal e não institucional. Não é da ONG X com o MP, por exemplo, mas da ONG X com o Promotor X. Se esta articulação não é institucionalizada, fica frágil, limitada.

Acho que isso é um defeito, acho que isso tem que ser feito pelo Estado, a organização e o traçado dessa política, e aí as ONGs entram como retaguarda. Hoje o que a gente vê é o contrário, fica desorganizado, porque a ONG tem uma limitação. Eu vejo que ainda não tem a consciência de todos os agentes do Estado, da saúde, dos agentes de polícia, dos conselhos tutelares, das penitenciárias, dos abrigos, não tem a consciência desse problema, do que é isso. Eu vejo que infelizmente, tem um preconceito. (P5)

A falta de consciência mencionada sugere a falta de articulação entre as políticas e a falta de capacitação dos agentes públicos. Para P2, a apresentação da temática pode levar a essa conscientização. Além disso, apropriados dos conhecimentos sobre o problema, os agentes podem auxiliar na reflexão sobre a política, juntando as competências para combater o tráfico de pessoas, cada um na sua seara.

E aí, depois deste momento de apresentação das pessoas à temática, é discutir criticamente como cada um dentro do seu expertise, dentro de sua atuação, pode trabalhar. É óbvia que nem todos nós vamos trabalhar no enfrentamento nem na repressão e responsabilização, mas podemos trabalhar na prevenção. Outros podem trabalhar no acolhimento á vítima ou no atendimento. (P2)

O II Plano Nacional de Enfrentamento ao Tráfico de Pessoas mostra especial preocupação com a divulgação do tema. Em três das cinco Linhas Operativas (LO) podemos observar a preocupação com a informação sobre o tema. Na LO 3 - Capacitação para o Enfrentamento ao Tráfico de Pessoas; LO 4 - Produção, Gestão e Disseminação de Informação e conhecimento sobre Tráfico de Pessoas; LO 5 - Campanhas de mobilização para o Tráfico de Pessoas. Essa 
preocupação com a informação provavelmente visa tirar o fenômeno da invisibilidade (tema abordado na categoria Desafios) e deste modo atingir possíveis vítimas, que com a informação poderiam ser salvas do aliciamento, como também pode atingir os gestores e profissionais do direito, para que tenham um olhar mais atento e cuidadoso para as possíveis vítimas que encontrem em suas práticas, possibilitando um resgate mais rápido e eficiente.

Um ponto que também envolve a articulação ou intersetorialidade do tema é a adequação dos equipamentos para atender às peculiaridades do tráfico. Para P2, os equipamento adequados para atuar no enfrentamento ao tráfico de seres humanos já existem, não é necessário criar órgãos especializados. É necessário, no entanto, as articulações corretas e o envolvimentos dos diversos agentes e mais uma vez a capacitação e o trabalho em rede para que nenhuma ação se perca do propósito maior de garantir o cuidado da vítima.

Então, dentro das políticas públicas eu não acredito que você precise inventar algo, porque já existem equipamentos. Para você trabalhar dentro dos equipamentos sociais e de terceiro setor que atendem as mulheres a temática do tráfico para que elas vejam, porque às vezes você vê um determinado caso que pode parecer, mas não é, mas ele pode também não parecer e ser tráfico, e às vezes você não dá encaminhamento nenhum ou dá outro encaminhamento porque você não conhece. (P2)

Também para P7 é desnecessária a criação de equipamentos ou programas específicos. Em algumas situações, talvez um profissional melhor qualificado (como um psicólogo, por exemplo), seja desejável, mas não um equipamento específico. Para o entrevistado, o que se faz necessário é capacitação, é articulação, é comunicação entre os diversos órgãos.

Precisaria criar um abrigo especial para meninas vítimas de tráfico de pessoas? Ou um abrigo para vítimas de exploração sexual com divisão para meninas e mulheres já seria o suficiente? Porque segmentar tanto? Eu trabalho com tráfico, vejo que tem algumas coisas que são específicas, mas não precisa ser tanto. Não precisa criar um programa específico. Acho que precisa criar pessoas... por exemplo, um psicólogo que estude este tema para tratar melhor a menina, e tudo o mais, ele precisa ter conhecimento do que ela passou e do tipo de tratamento 
que ela tem que ter, mas não precisa criar um abrigo prá isso. $\mathrm{O}$ que eu quero dizer é o seguinte: falta organização, falta comunicação, falta articulação. Porque que a PF não conversa com a defensoria e fala: Defensoria, a gente vai encaminhar para vocês todos os casos. Então encaminha! Fala que o horário de atendimento é tal. (P7)

O II Plano foca também na integração e fortalecimento das Políticas Púbicas e Redes de Atendimento (Linha Operativa 2). Essa integração só é possível quando todos os gestores e profissionais envolvidos conheçam muito bem suas funções, mas também as funções e potencialidades de todos os demais pontos da rede. $O$ desconhecimento das ações de outros órgãos acaba por muitas vezes negar a prestação de serviços necessários ao enfrentamento ao tráfico de pessoas. P7 traz o relato de uma atuação positiva, que ilustra a importância da articulação dos órgãos que compõem a política de enfrentamento.

Então, por exemplo, a defensoria se reuniu como Ministério do Trabalho (...) Então, o que eles perceberam: que não adiantava eles irem nas diligências, porque, o que 0 Ministério do Trabalho e Emprego faz, ele visita as empresas, pra ver se está tudo regularizado, pra ver se está com todas as normas de segurança em ordem, se tem extintores, se a fiação está aparente, se tem nota fiscal, todas essas normas trabalhistas e de segurança do trabalho e tudo o mais. (P7)

Mas, nessas diligências iniciais, o Ministério do Trabalho e Emprego não tinha nenhuma ação com as vítimas, nenhum encaminhamento que auxiliasse as vítimas a garantirem seus direitos, a regularizarem sua situação migratória. Com isso, a parceria surgiu como uma forma de auxiliar os migrantes a terem a possibilidade de regularizarem sua situação.

(...)Eu acho que essa articulação do comitê é a alma do negócio. É você colocar pessoas em contato, que podem fazer alguma coisa, principalmente nesse início, que não existia um procedimento, um fluxo de atendimento, não existia nada, existiam pessoas que queriam fazer alguma coisa e não sabiam como. (P7)

Antes da parceria, o Ministério do Trabalho e Emprego orientava os resgatados para procurarem a Defensoria Pública da União para se regularizar, mas isso não acontecia. P7 explica o porquê: 
Ninguém vinha aqui. Porque são pessoas que não sabem falar português, são pessoas medrosas, que não tem a segurança de andar por uma cidade desse tamanho, que estão amedrontadas pela situação que estão vivendo, mesmo sendo resgatadas, mesmo que uma autoridade tenha ido lá e dito que agora elas não precisavam trabalhar naquelas condições, é muito difícil elas se sentirem empoderadas de um dia para o outro. Quando começamos a ir pessoalmente, elas entendem que tudo aquilo é verdade. Elas são muito enganadas. (P7)

Para P8, o envolvimento dos agentes públicos é fundamental para que as vítimas tenham informações sobre o que é o tráfico de pessoas e como se proteger. Para o entrevistado, os agentes públicos tendo familiaridade com o tráfico de pessoas, serão agentes multiplicadores e identificadores das ações que configuram tráfico e poderão desta forma auxiliar as vítimas.

Eu penso que ações efetivas para as vítimas, elas estão ligadas a possibilidade de informações em canais de trânsito, seja por meio de agentes públicos informados, que possam estar, a partir de sintomas sociais, percebendo situações que possam parecer, envolver o tráfico de pessoas, que possam ter uma incisão naquela situação, isso na forma mais ampla possível. O envolvimento por parte dos agentes públicos, parte do pessoal da assistência social, pessoal da saúde, polícia, muitas das ações que envolvem Tráfico de Pessoas a ponta de lança do estado é a polícia, polícias, federal, rodoviária, guarda civil metropolitana, que embora não seja uma polícia tem esse caráter. É importante que essas pessoas tenham familiaridade com a temática, tenham acessibilidade para tratar do tema, que não tratem como uma situação que é alienígena. (...) Mas eu acho que o primeiro passo é esse, que os agentes públicos tenham uma familiaridade com o tráfico. (P8)

Para o entrevistado o segundo passo para auxiliar as vítimas num trabalho de prevenção, seria a divulgação através de campanhas, em articulação com o Ministério do Turismo.

O segundo é possibilitar informação, seja por meio de folders, panfletos, campanhas, campanhas que vão prá fora inclusive, que tenham... se o ministério do turismo faz campanha em outros países sobre as belezas naturais do Brasil, para que venham turistas prá cá, por que não fazer ações também, mas penso eu que é necessária, em lugares em que a gente vê trabalhadores, mulheres em situações de 
vulnerabilidade social mais acentuada, que já tenham mapeado um fluxo de tráfico propriamente, porque não nesses espaços fazer também uma campanha informando. (P8)

Nas entrevistas pudemos observar que além dessa articulação envolvendo atores diversos, é necessário fazer uma reflexão acerca da importância de cada órgão organizar as ações no que se refere ao enfrentamento ao tráfico de pessoas também por um olhar múltiplo, dentro da própria instituição. Um comprometimento institucional real, e não apenas com vistas a cumprir o protocolo de disponibilizar um profissional para a política. P1 traz a experiência do Ministério Público.

De 2010 pra cá a gente procurou incorporar à estrutura do $\mathrm{MP}$, institucionalizar na estrutura do Ministério Público a questão do enfrentamento ao Tráfico de Pessoas. (...) $O$ Ministério Público vê o tráfico como um assunto transversal, dentro de uma política de Direitos Humanos que se comunica com várias áreas de atuação. Essa foi uma questão que nós também nos debatemos demais, 0 exercício inicial nosso foi exatamente enxergar o tráfico dentro do capítulo dos Direitos Humanos e dentro do capítulo dos Direitos Humanos como uma diretriz de orientação de qualquer área de atuação do Ministério Público, seja na infância, seja na área de habitação e urbanismo, seja no consumidor, seja na área criminal, seja no patrimônio público, enfim, aonde houver a atuação do $\mathrm{MP}$, do mesmo jeito que eu tenho os Direitos Humanos como a minha diretriz de orientação na minha atuação nos mais variados sentidos, o tráfico é mais um destes muitos capítulos, como é a violência contra a mulher, como é a violência contra o idoso, enfim, não é porque eu estou na área $\mathrm{X}$ que eu nego o sincronismo e a convergência, então a gente viu nisso como um ponto central para que o tema pudesse dar os primeiros passos. (P1)

Um outro ponto que exige a articulação é o fato do tráfico de pessoas ser um crime transnacional, o que reforça ainda mais a necessidade da articulação das redes de atendimento. Para P3, só se combate o tráfico de pessoas com redes de atendimento, com união de esforços.

É um crime transnacional, envolve estados, soberania, aí começa a diplomacia. É um crime que tem rede criminosa e ele só é combatido, enfrentado, por meio de redes de atendimento. Você não consegue trabalhar com 
criminalidade organizada sem união de esforços e cooperação nacional e internacional, você não consegue. Você não consegue sozinho salvar o mundo. Principalmente no eixo atendimento à vítima, é que entra a sociedade civil comprometida também. O protagonista do enfrentamento ao Tráfico de Pessoas no Brasil é o Estado, mas demanda os coadjuvantes que é a sociedade civil, outros ministérios e assim vai. (P3)

A necessidade de um tratamento transnacional ao enfrentamento ao tráfico de seres humanos aparece, além do Protocolo de Palermo, pela cooperação internacional promovida pelo Brasil com pelo menos três importantes Organismos Internacionais: o Escritório das Nações Unidas sobre Drogas e Crime (UNODC), escritório da ONU responsável pelo suporte aos países no que se refere a medidas de enfrentamento ao tráfico e ao abuso de drogas e de substância ilícitas, à corrupção e ao crime organizado transnacional; o Centro Internacional para o Desenvolvimento de Políticas Migratórias (International Centre for Migration Policy Development - ICMPD) é uma organização internacional intergovernamental criada por iniciativa dos governos da Suíça e da Áustria em 1993 para prestar assistência técnica em matéria de migração e asilo; a Organização Internacional do Trabalho (OIT), tendo como principal objetivo fortalecer a capacidade das organizações nacionais para aplicar a legislação existente sobre o tema, bem como para implementar políticas e programas de combate ao tráfico de pessoas para fins de exploração sexual comercial e trabalho forçado ${ }^{54}$.

Uma leitura transnacional aparece também em pesquisas como "Jornadas Transatlânticas: uma Pesquisa exploratória sobre tráfico de seres humanos do Brasil para Itália e Portugal" (MINISTÉRIO DA JUSTIÇA, 2011) e "Pesquisa trinacional sobre tráfico de mulheres do Brasil e da República Dominicana para o Suriname: uma intervenção em rede" (HAZEU, 2008).

Para P5, a falta de articulação das políticas de combate ao crime organizado transnacional é uma falha diante de organizações que se articulam.

Onde se leva uma criança, se leva drogas, armas, prostitutas. Como a sociedade é muito conivente com

\footnotetext{
${ }^{54}$ Dados retirados do Portal do Ministério da Justiça em 25/11/2013.
} 
contrabando e descaminho, pra lá, vou ali comprar uma coisas no Paraguai, e aí passa pedra, passa droga, passa arma e passa gente. Não existe o tráfico de pessoas com o bandido especializado, como se só pudesse traficar pessoas. Pra ele tudo é mercadoria: pessoa, criança, feto, tudo. É só descartar e joga fora. Enquanto a gente tem uma política para o tráfico de drogas, uma política para o tráfico de armas, uma política para o tráfico de pessoas, uma política para não sei o que... eles canalizam. (P5)

Uma política articulada com vistas a atender ao tripé proposto pela política é importante e segundo P2 pode representar um ganho multidimensional e significar redução de danos

Então veja: qual é a nossa grande dificuldade, nossa grande
desafio: é que o Estado incorpore a temática e possa
entender que ao desenvolver e implementar políticas
públicas para o enfrentamento ao tráfico, para a repressão e
a responsabilização e para acolhimento à vítima, ele vai ter
um ganho político multidimensional, porque ele vai ter um
impacto econômico muito interessante, tanto na redução dos
danos, de potenciais danos que estas vítimas poderiam
sofrer, tanto na melhoria da qualidade de vida dessas
vítimas ou dessas potenciais que poderiam sair do alvo
destas redes de aliciamento, como pensar num sistema de
segurança pública, num sistema judicial que possa resolver
a situaçãa. (P2)

Essa preocupação é legítima, uma vez que se o bem que se propõe preservar e proteger é a dignidade da pessoa, o que deve ser evitado é a prática do delito, fator minimizado pela prevenção. Caso o fenômeno do tráfico ocorra, a atenção e acolhimento à vítima são fundamentais para que se tente resgatar a dignidade. Deste modo, o caráter repressivo, apesar de necessário para coibir a prática delitiva, não deveria ser encarado como o viés mais importante e encorpado da política. Quando isso ocorre, o que vemos é mais uma vez o "mais Estado" policial e penitenciário sobressaindo ao "menos Estado" social (WACQUANT, 2001, p. 07).

Negar a importância de um Estado que priorize a dimensão social e humana, é fechar os olhos para as incisivas violações aos direitos humanos e tratar as mesmas como acaso ou azar do indivíduo que não consegue romper 
com a subjugação e com a negativa de direitos. É responsabilizar mais uma vez a vítima por sua vulnerabilidade social. 


\section{7 - CONSIDERAÇÕES FINAIS}

Este trabalho visou, a partir de uma análise das representações sociais dos profissionais do Direito sobre a política de enfrentamento ao tráfico de pessoas, tecer reflexões sobre a política em questão e sobre a atuação dos profissionais do Direito em políticas públicas de Direitos Humanos.

A investigação por meio da teoria das representações sociais permitiu uma análise que aproveitasse as vivências, as práticas, o olhar, o sentir, a voz dos profissionais do direito, não se atendo somente à dureza da lei e ao rigor de uma atividade diária voltada para o cumprimento de prazos, e para o preenchimento de relatórios. Investigar as representações sociais permitiu compreender o Direito muitas vezes encolhido na dogmática que o afasta da sociedade - como um saber que urge em ampliar sua dimensão para o social.

Fazer uma pesquisa em Direito pelo viés dos Direitos Humanos é necessariamente aceitar trabalhar em uma corrente contra majoritária, com um discurso contra hegemônico. Não é possível buscar consenso e este não será encontrado. Mas é interessante identificar que os profissionais entrevistados e que foram sujeitos desta pesquisa, estavam dispostos a conversar sobre uma política ainda em construção, notadamente permeada por uma perspectiva humanista, e que estes profissionais mostravam-se constantemente abertos a refletir sobre suas práticas e sobre o Direito.

Isso foi identificado primeiro com a grande disponibilidade apresentada pelos profissionais com os quais foi feito contato e que se mostraram amplamente abertos e acessíveis a disporem de seu tempo para participar de uma pesquisa feita por uma doutoranda completamente desconhecida. Não havia relação alguma anterior com nenhum dos profissionais e o primeiro contato foi feito por email, apresentando o projeto e solicitando uma entrevista, no que os profissionais atenderam prontamente. A disponibilidade se mostrou também na adequação de suas atribuladas agendas para encaixarem um horário em que seria possível a consecução destas entrevistas. E por fim, disponibilidade que se fez presente no 
interesse destes profissionais em falar sobre sua atuação na Política de Enfrentamento ao Tráfico de Pessoas, por até três horas e quarenta minutos (duração da entrevista mais longa).

Essa disponibilidade permitiu cumprir com os objetivos inicialmente propostos para este trabalho. Para chegar ao objetivo geral e principal que foi investigar qual representação social têm os profissionais jurídicos sobre a Política Pública de Prevenção e Enfrentamento ao Tráfico de Pessoas e sobre as vítimas dessa prática criminosa, a busca foi em compreender entre outras coisas: como os profissionais analisavam a política de enfrentamento ao tráfico de seres humanos, quais os sujeitos eram tidos pelos entrevistados como vítimas potenciais no Estado de São Paulo e qual o olhar que tinham acerca desses sujeitos, conhecer as motivações e os desafios enfrentados pelos profissionais nas suas ações em defesa dos direitos humanos. Além disso, foi possível, evidenciar a importância de um olhar interdisciplinar na política pública de enfrentamento ao tráfico humano.

Todos estes objetivos de certa forma apareceram nas categorias que pinçamos das entrevistas o que permitiu ser traçada uma reflexão sobre problema tão complexo e multifacetado - o qual ficou ainda mais complexo quando mesclada à discussão sobre a política - trouxemos a atuação dos profissionais do direito. Unir política pública, tráfico de pessoas e atuação dos juristas em um mesmo trabalho mostrou-se ser interessante para que fosse possível, entre outros aspectos, refletir sobre a formação dos profissionais do Direito, tema a mim caro, em razão da minha inserção docente desde 2003.

A definição de cinco categorias para a análise deveu-se à necessidade de limitar o trabalho. Outros temas poderiam ter sido aproveitados de todo o material coletado em forma de entrevistas, mas era necessário priorizar alguns pontos entendidos como essenciais para discutir o proposto. Além disto, a recorrência do conteúdo nas falas foi fundamental para a compreensão de que as categorias escolhidas são o reflexo dos temas priorizados pelos sujeitos.

Estudar as representações sociais dos profissionais do direito sobre tráfico de pessoas nos permitiu analisar alguns pontos importantes envolvendo a 
atuação desses profissionais. Algumas dimensões trazidas pelos juristas nos auxiliaram na construção de reflexões que agora comporão estas considerações finais.

Um primeiro ponto que exige nossa reflexão é o fenômeno do tráfico de pessoas e a Política de Enfrentamento em questão. A globalização e a facilidade do deslocamento humano acabaram por disponibilizar um exército de potenciais trabalhadores para todas as partes do mundo e em muitos lugares o excesso de trabalhadores favorece a submissão dos mesmos a condições de exploração e escravidão. A condição dos imigrantes, em sua maioria indocumentados, aparece como facilitadora do tráfico, uma vez que os indivíduos, coagidos pela situação irregular em que se encontram, acabam por não terem como lutar contra a exploração. Em pior situação se encontra a mulher, migrante, explorada sexualmente.

As vítimas do tráfico de pessoas são submetidas a diversas violações, que começam antes da prática do crime e que muitas vezes tornam vulneráveis os indivíduos a ponto de serem aliciados. Violações que ocorrem no aliciamento em si, neste momento de transição entre a vida livre e a vida subjugada. Violações que ocorrem no curso da subjugação, que torna o indivíduo refém, escravo, coisa. Em cada um desses momentos é fundamental que o Direito se apresente como uma saída, como um instrumento garantidor do acesso à vida, à liberdade, à dignidade. Neste processo, é necessário que os profissionais do Direito se posicionem.

Enxergar num sujeito que chega ao sistema de saúde, de segurança, de justiça, como potencial vítima do tráfico de pessoas é uma necessidade urgente, para que os órgãos públicos consigam agir de maneira eficiente na prevenção. Os profissionais do Direito são agentes fundamentais nesse processo, uma vez que diversas violações chegam até delegados de polícia, advogados, defensores públicos e promotores de justiça e somente um olhar atento e sensível às diversas facetas que cobrem as inúmeras violências sofridas por indivíduos vulnerabilizados socioeconomicamente, podem revelar um sujeito a mercê de se tornar vítima do tráfico de pessoas. 
O Brasil há dez anos se compromete com a política de enfrentamento ao tráfico de pessoas sendo inegáveis os avanços alcançados no decorrer deste período. Ainda assim, muito há que conquistar, sobretudo, no que se refere à articulação da política, na atenção à vítima, na efetividade de uma rede de proteção, na definição e um marco regulatório que responsabilize os culpados por todas as violações perpetradas entre o aliciamento e a exploração da vítima de tráfico de pessoas.

Um passo importante foi dado com a elaboração do segundo Plano Nacional de Enfrentamento ao Tráfico de Pessoas caracterizado por ter sido construído coletivamente com a participação de Ministérios, organismos internacionais, estados e sociedade civil. Esta construção coletiva revela a importância em uma política estruturada interdisciplinarmente, possibilitando a contribuição de diversos olhares e saberes na elaboração de uma política pública.

Dentre os objetivos propostos neste trabalho, um desafio ainda em aberto é analisar se a forma como os profissionais veem a política e os sujeitos nela envolvidos pode alterar a efetividade das mesmas. Não é possível chegar a esta conclusão a não ser que seja feita uma análise contínua da política e uma reflexão pormenorizada de seus resultados. As políticas públicas em si são caracterizadas pela integralidade e intersetorialidade, o que necessariamente dilui a atuação de um grupo de sujeitos como definidora de seus resultados. A leitura de uma política deve ser feita na sua organicidade, sob a pena de não ser possível dimensionar a efetividade de seus propósitos. Fracionar a política na atuação de um segmento (neste caso, nos profissionais do Direito), é tirar o caráter político da mesma, e sobre isso não havíamos pensado antes de adentrarmos no tema.

A articulação na construção da política pode ser importante também como uma tentativa de romper com um problema apontado pelos profissionais jurídicos entrevistados no que se refere à descontinuidade da política e a falta de comprometimento institucional. Entendemos que a construção coletiva pode favorecer o comprometimento dos órgãos envolvidos uma vez que a parceria, começando na elaboração da política, provavelmente terá mais força nas ações de efetivação da política. 
Um outro ponto que nos chamou a atenção e merece um relevo nestas considerações finais, refere-se às análises dos profissionais sobre sua atuação como atores jurídicos. Não é fácil falar de si, sobretudo se este falar transcende o indivíduo para alcançar uma categoria de indivíduos, aqui, no caso, os profissionais do Direito. No mesclar entre falar de si e falar da categoria, observamos também que os profissionais falam dos outros. Isso porque em alguns momentos observamos que os profissionais se viam como categoria única e em outros como categorias profissionais diferentes e até discordantes.

Isso mostra como a imagem de si começa pela reflexão da alteridade, pelo olhar para o outro. Ao analisar seu agir e o agir dos outros profissionais, cada jurista constrói e reconstrói seu olhar para suas práticas e nesse exercício, podemos entender que pensar as práticas, as potências e fragilidades da atuação como juristas, permite ressignificar sua atuação e construir novas possibilidades do agir, revelando uma possível dimensão transformadora do Direito.

Se a transformação se procederá, só o futuro dirá. Mas de tudo que foi dito, entendemos ser interessante ressaltar a consciência de existir no profissional do direito um sujeito com uma história pessoal, com valores, preconceitos e que esta constituição individual irá cercar toda a atuação do profissional.

Não se pode negar que a vida profissional é apenas uma das diversas facetas da vida do indivíduo e que o sujeito não se despe de si mesmo ao vestir a toga do profissional. Não se pode negar, deste modo, que os valores, preconceitos e discriminações construídas na formação do indivíduo acabam por permear a conduta profissional. Não se pode negar, por fim, que a formação acadêmica dos profissionais tem grande influência na forma como constroem suas práticas.

Diante disso, ressaltamos que a formação profissional deve ser uma preocupação constante, o que tem sido observado em trabalhos como os organizados por Faria (1989 e 1994), o livro coordenado por Nalini e Carlini (2010), e também pela produção de Boaventura de Sousa Santos (1995, 2003, 2004, 2005, 2007 e 2007a). Nesses trabalhos os autores problematizam a formação profissional e ressaltam a importância em se conciliar a teoria à prática, 
esta, necessariamente entendida como uma imersão nos problemas sociais. Não basta uma imersão no mundo das leis e dos códigos. É necessária uma formação emancipatória, pautada verdadeiramente no tripé ensino-pesquisa-extensão, assentada "numa ecologia de saberes jurídicos, no diálogo entre o conhecimento jurídico popular e científico, e numa aplicação edificante da ciência jurídica, em que aquele que aplica está existencial, ética e socialmente comprometido com o impacto de sua atividade" (SANTOS, 2007, p. 73-74)

Deste modo, é necessário pensar uma formação jurídica que transcenda à dimensão técnico-positivista do Direito, que acolha o debate sobre o papel do Direito como instrumento transformador, que encare o Direito como um espaço não somente de leis, doutrinas e jurisprudências, mas também como um espaço de indivíduos, de sujeitos que trazem para os conflitos jurídicos suas angústias e frustações. Pensar o Direito como um instrumento para pacificação de conflitos e emancipação social exige do profissional do Direito mais do que técnica: exige um olhar ampliado para as desigualdades e mazelas sociais.

Se nas salas das Faculdades de Direito se formar para a dignidade, nos fóruns e tribunais esta dignidade tem grande chance de ser reproduzida. Ainda que compreendamos que a vida profissional não é o único espaço de formação do sujeito, que se constrói a cada encontro, a cada troca, a cada olhar, acreditamos que a formação jurídica pautada neste "compromisso com a vida" pode de fato gerar "homens melhores" ${ }^{35}$ que aprendam a ter um olhar despido de preconceitos, um olhar que não seja tendencioso a restringir a pessoa a apenas uma dimensão (gênero, origem social, por exemplo), pois acreditamos que o sujeito é multideterminado e assim deve ser compreendido.

A pesquisa sobre o tráfico de seres humanos numa perspectiva em Direitos Humanos revelou a necessidade de formação continuada neste ramo do Direito, tanto dos profissionais jurídicos como também dos trabalhadores da saúde, vigilância sanitária, órgãos financeiros e tributários de prefeituras (que expedem alvarás), para evitar a reprodução de valores contrários à dignidade humana. Entendemos que a qualificação permanente e o reforço dos valores da dignidade

\footnotetext{
${ }^{55}$ Expressões retiradas de Warat, 2004, p. 388.
} 
da pessoa devem ser vistos como meta das políticas públicas e ações governamentais no enfrentamento do tráfico, com ações de prevenção, repressão e atendimento às vítimas - com ênfase para essa última abordagem.

Ações de acolhimento à vítima mostram-se como ponto fundamental, sobretudo por ser neste eixo que a vítima de fato aparece e pode ser protegida pela política. O olhar com relação à vítima, o reconhecimento da mesma como um sujeito de direito é condição essencial para que a dignidade deste sujeito, violada no tráfico de pessoas, seja resgatada. A reflexão sobre a formação e a capacitação $^{56}$ nos leva também a compreender que o olhar dos profissionais com relação às vítimas do tráfico de pessoas, pode estar permeado por preconceitos muitas vezes travestidos de cuidado.

O acolhimento à vítima deve passar necessariamente pela assistência e pela reinserção deste indivíduo socioeconomicamente, com vistas a evitar uma revitimização. A atenção à vítima deve ser pautada em primeiro lugar pela identificação da condição de exploração, depois pela libertação, passando pelo cuidado psicossocial e pela recolocação socioeconômica. Somente um indivíduo protegido integralmente, acolhido em todas as dimensões do humano, pode ter forças para identificar-se como vulnerável e com isso lutar contra a opressão e o assujeitamento. As políticas públicas têm que ser adequadas para este acolhimento estendido, e para isso, mais uma vez, a articulação entre as diversas instituições comprometidas com a política, é fundamental.

No que se refere aos profissionais do Direito, ações importantes devem ser desenvolvidas no tocante à capacidade dos órgãos de justiça em proteger as vítimas de serem tratadas como responsáveis pela prática delitiva. Em diversos momentos as falas dos entrevistados apontaram para um olhar para a vítima como facilitadora da exploração. Seja a vítima de exploração sexual, o imigrante irregular, a vítima de tráfico de órgãos, é muito comum que haja um olhar de distanciamento com relação a estes sujeitos, o que acaba por levar a um ciclo vicioso em que tudo começa e termina na vítima.

\footnotetext{
${ }^{56}$ Também compreendida como a sensibilização, a formação continuada, as especializações, ou seja, qualquer espaço em que os sujeitos possam rever seus conceitos sobre determinado tema fundamental para a sua atuação profissional, ou apropriarem-se de novos saberes que ajudarão na definição de suas práticas.
} 
Forçoso é, diante do vilipêndio à dignidade provocado pelo tráfico de pessoas, refletir sobre a dignidade vinculada à autonomia e consentimento: será possível falar em escolha diante da falta de outra opção? Será possível falar em consentimento diante da coação ou da ignorância? Existe autonomia para a disposição de bens considerados, pelo Direito, como inalienáveis? Como não considerar que a miséria, para muitas pessoas em todo o mundo funciona como um motor que leva à relativização de valores e direitos e a submissão a condições socioeconomicamente precárias?

A resposta a essas perguntas passa necessariamente pela reflexão acercada da inclusão social. Diminuir as desigualdades é ponto fundamental de uma sociedade que se pretende justa e solidária, e este é um dos principais desafios enfrentados pelos estudiosos em Direitos Humanos. A luta por Direitos Humanos é uma luta contra majoritária e contra hegemônica, e nessa perspectiva não teria o Direito e as relações jurídicas como aliados, caso o Direito continue sendo aliado dos modelos de globalização hegemônica, que expulsa grande parcela da população de seus direitos sociais, econômicos e culturais mínimos.

Na busca dos Direitos Humanos por uma sociedade justa, solidária e igualitária, é fundamental procurar compreender o que é o homem, o que é dignidade humana além de tentar trazer luz sobre tudo aquilo que impede a efetivação desta dignidade. O Direito pode se transformar em importante instrumento para a concretização da promoção da dignidade, se assumir seu viés emancipatório e progressista.

Uma das grandes questões enfrentadas pelos estudiosos em Direitos Humanos é encontrar formas de diminuir os efeitos provocados pelas estruturas de poder econômico e social como limitadoras ou impeditivas da dignidade humana; é buscar entender as expectativas do ser humano na busca de uma vida digna, é compreender o que impede a efetivação da dignidade humana. Em nossa sociedade complexa, temos de um lado o poder econômico ditando regras e tomando conta de tudo enquanto, de outro, o Direito se acovarda, encolhe-se, ensimesmando-se sobre a norma e afastando-se dos problemas da vida cotidiana, real. Nesse quadro, a dignidade humana não é priorizada e os valores de uma sociedade justa e solidária estão cada vez mais distantes. Políticas mais 
efetivas contra o tráfico de pessoas passam necessariamente pela reflexão de que para enfrentar a força do poder econômico que menospreza a dignidade, o Direito precisa se mostrar.

Na política de enfrentamento ao tráfico de pessoas, os profissionais do Direito devem assumir o protagonismo das ações em todos os eixos propostos, uma vez que são agentes importantes neste processo. Seja como agentes da política, seja como profissionais que levam ao judiciário as demandas que envolvem o tráfico de pessoas, em qualquer das dimensões, entendemos ser fundamental que haja uma reflexão sobre a educação em direitos humanos, que deve começar nos primeiros anos do ensino fundamental, para que todo sujeito se comprometa com a coletividade e acompanhar todos os profissionais, de qualquer área, nos bancos das faculdades e na vida profissional. A formação fundamentada em um referencial humanista apresenta-se como crucial para que os profissionais do Direito - dos bancos das faculdades de direito para a vida - tenham uma prática comprometida com os ideais dos direitos humanos, com a dignidade humana, com a inclusão social e com a dimensão social do Direito. 


\section{0 - REFERÊNCIAS}

ACHARYA, Arun Kumar; STEVANATO, Adriana Salas. Violencia y tráfico de mujeres en México: una perspectiva de género. Revista Estudos Femininos, Florianópolis, 13(3) 320, setembro,-dezembro/2005.

ADORNO, Sérgio. Crime, Justiça penal e desigualdade jurídica - As mortes que se contam no tribunal do júri. Revista USP, São Paulo, n. 21, p. 132-151, Mar/Mai 1994.

AGNOLETI, Michele Barbosa. Travestis e o Sonho Europeu. In Fazendo Gênero 8 - Corpo, Violência e Poder. Florianópolis, Ago-2008, acessado em 05/10/2013, disponível em http://www.fazendogenero.ufsc.br/8/sts/ST16/AgnoletiMello Neto 16.pdf.

AGUSTIN, Laura M. Migrants in the Mistress's House: Other Voices in the "Trafficking" Debate. Social Politics: International Studies in Gender, State and Society 12 (1), Oxford University Press, 2005, pp. 96-117.

AITH, Fernando. Políticas Públicas de Estado e de governo: instrumentos de consolidação do Estado Democrático de Direito e de promoção e proteção dos Direitos Humanos. In: BUCCI, Maria Paula Dallari (Org.). Políticas Públicas reflexões sobre o conceito jurídico. São Paulo: Saraiva, 2006, p. 217-245.

ALIANÇA GLOBAL SOBRE O TRÁFICO DE MULHERES. Direitos Humanos e Tráfico de Pessoas: um manual. Rio de Janeiro: [S.N.], 2006.

ALMEIDA PRADO, Lídia Reis. O Juiz e a Emoção - Aspectos da Lógica da Decisão Judicial. Campinas: Millenniun, 2010.

ALMEIDA, Luciana Campello Ribeiro; NEDERSIGT, Frans. Critérios e fatores de identificação de supostas vítimas do tráfico de pessoas / Secretaria Nacional de Justiça, Escritório das Nações Unidas contra Drogas e Crimes (UNODC) Brasília: Ministério da Justiça/SNJ, UNODC, 2009. 
ANDERSON, Bridget; DAVIDSON, Julia O'Connell. Trafficking - a demand led problem? A multi-country pilot study. Sweden: Save the children, 2002. ISBN 91-7321-069-2.

ANDRADE, Vera Regina Pereira de. Criminologia e feminismo: da mulher como vítima à mulher como sujeito de construção da cidadania. In: CAMPOS, Carmen Hein de. Criminologia e feminismo. Porto Alegre, Sulina, 1999, pp.105-117.

AUSSERER, Caroline. Controle em nome da Proteção: análise crítica dos discursos sobre o tráfico internacional de pessoas. São Paulo: PUC, 2007.

BALDIN, Nelma ; MUNHOZ, Elzira M. Bagatin. Snowball (Bola de Neve) : uma técnica metodolgica para pesquisa em educação ambiental comunitária. Curitiba : X Congresso Nacional de Educação - EDUCERE/I Seminário Internacional de Representações Sociais, Subjetividade e Educaçao - SIRSSE, 2011.

BANCHS, María A. Aproximaciones procesuales y estructurales al estúdio de las representaciones sociales. Paper on social represetations, vol. 9, Peer Reviewed Online Journal, p. 3.1-3.15, 2000a. . La psicología social como pratica politicoetica. Psicología e Sociedade, 12 (1/2), p. 32-53, jan-dez. 2000b.

BARBOZA, Estefânia Maria de Queiroz; KOZICKI, Katya. Judicialização da Política e Controle Judicial de Políticas Públicas. Revista Direito GV São Paulo, 8 (1), Jan/jun 2012, p. 59-86.

BARDIN, Laurence. Análise de Conteúdo. Lisboa: Edições 70, 1979.

BASSEGUIO, Luiz; FREIRE, Roberval. Nadie es ilegal en donde quiere que viva. In Sydow, Evanize e Mendonça, Maria Luisa. Direitos Humanos no Brasil, 2005

BAUMAN, Zygmunt. O Mal-Estar da Pós Modernidade. Tradução de Mauro Gama, Claudia Martinelli Gama. Rio de Janeiro: Jorge Zahar, 1998.

Comunidade. Tradução de Plínio Dentzien. Rio de Janeiro: Jorge Zahar, 2003. 
.Vidas Desperdiçadas. Tradução Carlos Alberto Medeiros. Rio de Janeiro: Jorge Zahar, 2005.

. Vida Líquida. Tradução Carlos Alberto Medeiros. Rio de Janeiro: Jorge Zahar, 2007.

BECKER, Howard. S. Métodos de Pesquisa em Ciências Sociais. São Paulo: Hucitec, 1997.

BEGNIS, Heron Sergio Moreira; ESTIVALETE, Vania de Fátima Barros; PEDROZO, Eugênio Ávila. Confiança, comportamento oportunista e quebra de contratos na cadeia produtiva do fumo no sul do Brasil. Gestão Produtiva, São Carlos, v. 14, n. 2, p. 311-322, 2007.

BITTAR, Eduardo Carlos Bianca. Direito na pós-modernidade e reflexões frankfurtianas. $2^{\mathrm{a}} \mathrm{ed}$. rev. atual. e ampliada. Rio de Janeiro: Forense Universitária, 2009.

BLANCHETTE, Thaddeus; DA SILVA Ana Paula. 2012. On bullshit and the trafficking of women:moral entrepreneurs and the invention of trafficking of persons in Brazil, Dialectical Anthropology, 36:107-125, DOI 10.1007/s10624012-9268-8. Disponível em http://link.springer.com/article/10.1007/s10624-0129268-8\#page-2, acesso em 15/11/2013.

BLACKBURN, Robin. The overthrow of colonial slavery. New York: Verso World History Series, 2000.

BOBBIO, Norberto. A Era dos Direitos. Rio de Janeiro: Ed. Campus, 1992.

BRASIL, Constituição da República Federativa do Brasil. Brasília: Diário Oficial da União, 05 de outubro de 1988.

BRASIL, Decreto oㅜ 5017, de 12 de março de 2004. Brasília: Diário Oficial da União, 15 mar. 2004.

BRASIL. Decreto ํㅜ 5.948, de 26 de outubro de 2006. Brasília: Diário Oficial da União, 27 out. 2006. 
BRASIL - Secretaria Nacional de Justiça (SNJ). Relatório: indícios de tráfico de pessoas no universo de deportadas e Não admitidas que regressam ao Brasil via o aeroporto de Guarulhos - Secretaria Nacional de Justiça. Brasília: Ministério da Justiça, 2006.

BRASIL. "Plano Nacional de Educação em Direitos Humanos / Comitê Nacional de Educação em Direitos Humanos". - Brasília: Secretaria Especial dos Direitos Humanos, Ministério da Educação, Ministério da Justiça, UNESCO, 2007.

BRASIL. Decreto no 6347, de 08 de janeiro de 2008 (I Plano Nacional de Enfrentamento ao Tráfico de Pessoas). Brasília: Diário Oficial da União, 09 de janeiro de 2008.

BRASIL. Portaria oㅡ 31, Secretaria Nacional de Justiça, de 20 de agosto de 2009. Brasília: Diário Oficial da União, 31 de agosto de 2009.

BRASIL - Secretaria de Direitos Humanos. Relatório sobre violência homofóbica no Brasil: Ano de 2012. Brasília: SDH, 2012.

BRASIL. II Plano Nacional de Enfrentamento ao Tráfico de Pessoas. Ministério da Justiça. Secretaria Nacional de Justiça. DOU. Brasília: SNJ, 2013.

BRASIL - Ministério da Justiça (MJ). Tráfico de Pessoas, Marco Legal, II Plano Nacional. Brasília: Ministério da Justiça, 2012. Disponível em http://portal.mi.gov.br/data/Pages/MJE8833249ITEMIDB5014675B7634282891A7 84E0688387APTBRNN.htm, acesso em 08/07/2012.

BRASIL. Secretaria Nacional de Justiça. II Plano nacional de enfrentamento ao tráfico de pessoas. Brasília: Ministério da Justiça, 2013.

BRUCKERT, Christine. Trafficking in Human Beings and Organized Crime: A Literature Review. University of Ottawa, 2002. Disponível em: http://www.rcmpgrc.gc.ca/pdfs/traffick e.pdf , acessado em 08/06/2012.

BUCCI, Maria Paula Dallari. Buscando um conceito de políticas públicas para a concretização dos Direitos Humanos. In: et al. Direitos humanos e políticas públicas. Cadernos Polis. São Paulo, Pólis, 2001. 
. O Conceito de Política Pública em Direito. In: (Org.).

Políticas Públicas - reflexões sobre o conceito jurídico. São Paulo: Saraiva, 2006, p. 01-49.

BUSSO, Gustavo. Vulnerabilidad social: nociones e implicancias de políticas para latinoamerica a inicios del siglo XXI. Seminario Internacional: las diferentes expresiones de la vulnerabilidad social en América Latina y el Caribe. Santiago de Chile: CELADE, 2001. Disponível em http://www.cepal.cl/publicaciones/xml/3/8283/GBusso.pdf, acesso em 15/10/2013.

CALDEIRA, Teresa Pires do Rio. Direitos Humanos ou "Privilégio de Bandido"? Revista Novos Estudos CEBRAP: junho 1991, oㅡ 30, pp. 162-174.

CAMPILONGO, Celso Fernandes. Os desafios do Judiciário: um enquadramento teórico. In: FARIA, José Eduardo (Org.). Direitos humanos, direitos sociais e justiça. São Paulo: Malheiros, 1994.

CANÇADO TRINDADE, Antonio Augusto. Direitos Econômicos e Sociais. In A incorporação das normas internacionais de proteção dos direitos humanos no direito brasileiro. 2. ed. San José: IIDH, 1996.

CAPES, 2012. Disponível em http://www.capes.gov.br/servicos/banco-deteses, acesso em 10/06/2012.

CASTILHO, Ela Wieko. V. A Criminalização do Tráfico de Mulheres: proteção das mulheres ou reforço da violência de gênero? Cadernos Pagu (31), Campinas-SP, Núcleo de Estudos de Gênero - Pagu/Unicamp, jul./dez. 2008, pp.101-123. Tráfico de pessoas: da Convenção de Genebra ao Protocolo de

Palermo. Cartilha do Ministério da Justiça: Política Nacional de Enfrentamento ao Tráfico de Pessoas. Brasília, 2007. Disponível em http://pfdc.pgr.mpf.gov.br/atuacao-e-conteudos-de apoio/publicacoes/trafico-depessoas/artigo_trafico_de_pessoas.pdf, acesso em 09/06/2012.

CHEJTER, Silvia. Lugar Común - La Prostitución. Buenos Aires: Eudeba, 2010. 
COLARES, Marcos. I Diagnóstico sobre Tráico de seres Humanos: São Paulo, Rio de Janeiro, Goiás e Ceará. Brasília: Secretaria Nacional de Justiça, 2004.

COMPARATO, Fabio Konder. A Afirmação Histórica dos Direitos Humanos. São Paulo: Saraiva, 2008.

Conferência Judicial Ibero-Americana. Regras de Brasília sobre o acesso à justiça das pessoas em condições de vulnerabilidade. Brasília: XIX Conferência Judicial Ibero-Americana, março 2008.

DAL BOSCO, Maria Goretti. Garantia de Direitos Fundamentais Sociais diante do Princípio da Eficiência nas Políticas Públicas. Revista do Movimento do Ministério público Democrático, ano VI, № 27, outubro 2009, p. 32-33.

EUROPEAN COMMISSION. Reports of the Experts Group on Trafficking in Human Beings. Bruxelas: Directored General Justice, Freedom and Security, Dez-2004.

FARIA, José Eduardo (Org.). Direito e Justiça - A Função Social do Judiciário. São Paulo: Ática, 1989.

( (Org.). Direitos Humanos, Direitos Sociais e Justiça. São Paulo:

Malheiros, 1994. . Os desafios do Judiciário. Revista USP, 21: 46-57, mar./abr./mai. 1994a.

FERRAZ JR., Tércio Sampaio. A Trivialização dos Direitos Humanos. Novos Estudos Cebrap, no 28, p. 99-115, out. 1990.

. O Futuro do Direito. Revista USP, São Paulo, n.74, p. 6-21, junho/agosto 2007.

FERREIRA, Isabel Teresa Carone Mayrink. A Construção Social do Tráfico de Pessoas. Rio de Janeiro: UFRJ/Museu Nacional/PPGAS, Dissertação de Mestrado, 2009, 128p. 
FINKLEA, Kristin M.; FERNANDES-ALCÂNTARA, Adrienne L.; SISKIN, Alison. Sex Trafficking of Children in the United States: Overview and Issues for Congress. Washington: Congressional Research Service, June 21, 2011.

FRASER, Nancy. Reconhecimento sem Ética? Revista Lua Nova, São Paulo, 2007.

FRINHANI, F. M. D. Mulheres Encarceradas: representando o universo prisional. Vitória - ES, UFES/Departamento de Psicologia Social - Centro de Ciências Humanas e Naturais, Dissertação de Mestrado, 2004, 145p.

FUNARO, Vânia Martins Bueno de Oliveira. (Coord.) et. al.. Diretizes para apresentação de dissertações e teses da USP: documento eletrônico e impresso Parte I (ABNT). São Paulo: Sistema Integrado de Biblioteca da USP, 2009.

FURTADO, Celso. Formação econômica do Brasil. São Paulo: Cia Ed. Nacional, 2003.

GIAMMARINARO, Maria Grazia. Human trafficking is intolerable in a civilized world, says OSCE Special Representative on Anti-Trafficking Day. Viena: Orga- nization for Security and Co-operation in Europe (OSCE), 2011.

GRUPO DAVIDA (2005), Prostitutas, "traficadas" e pânicos morais: uma análise da produção de fatos em pesquisas sobre o "Tráfico de seres humanos". Cadernos Pagu (25), Campinas-SP, Núcleo de Estudos de Gênero Pagu/Unicamp, jul./dez. 2005, pp.153-184.

GUARESCHI, Pedrinho; JOVCHELOVITCH, Sandra. Prefácio. In. (Orgs.) Textos em Representações Sociais. 7. ed. Petrópolis, RJ: Vozes, p. 7-25, 2002. GUERALDI, Michelle; DIAS, Joelson. Em Busca do Eden: Tráfico de Pessoas e Direitos Humanos, Experiência Brasileira. São Paulo: Max Limonad, 2012.

GUERRA, Andréa. M. C. et. al. (Orgs.). Psicologia Social e Direitos Humanos. Belo Horizonte: Edições Campo Social, 2003. 
HAZEU, Marcel Theodor. et al (Coord.). Pesquisa tri-nacional sobre tráfico de mulheres do Brasil e da República Dominicana para o Suriname: uma intervenção em rede. Belém: Sodireitos, 2008.

HONNETH, Axel. 1992. "Integrity and disrespect: principles of a conception of morality based on the theory of recognition". Political Theory, n. 20(2), p. 188189.

HONNETH, Axel. Reconhecimento ou redistribuição? A mudança de perspectivas na ordem moral da sociedade. In: SOUZA, Jessé; MATTOS, Patrícia (orgs.). Teoria Crítica no século XXI. São Paulo: Annablume, 2007, pp. 79-83.

ILLES, Paulo; TIMOTEO, Gabrielle Louise Soares; FIORUCCI, Elaine da Silva. Tráfico de Pessoas para fins de exploração do trabalho na cidade de São Paulo. Cadernos Pagu, Campinas, n. 31, Dec. 2008.

IPEA - Instituto de Pesquisa Econômica Aplicada. Retrato das desigualdades de gênero. Brasília: Ipea, 2011. Disponível em http://www.ipea.gov.br/retrato/livreto.html, acesso em 08/11/2013.

IPEA - Instituto de Pesquisa Econômica Aplicada. GARCIA, Leila Posenato.Violência contra a mulher: feminicídios no Brasil. Brasília: IPEA, 2013. Disponível em http://www.ipea.gov.br/portal/images/stories/PDFs/130925 sum estudo feminicidi o leilagarcia.pdf, acessado em 08/11/2013.

IRWIN, Mary Ann. "White Slavery" As Metaphor: Anatomy of a Moral Panic. In: V Ex Post Facto: The History Journal, 1996. Disponível em: http://www.walnet.org/csis/papers/irwin-wslavery.html, acesso em 09/06/2012.

JACÓ-VILELA, Ana Maria; SATO, Leny. Diálogos em Psicologia Social. Rio de Janeiro: centro Edelnstein de Pesquisas Sociais, 2012.

JAPIASSU, Hilton. Interdisciplinaridade e Patologia do Saber. Rio de Janeiro: Imago, 1976. 
JESUS, Damásio de. Tráfico Internacional de Mulheres e Crianças - Brasil Aspectos Regionais e Nacionais. São Paulo: Saraiva, 2003.

JOVCHELOVITCH, Sandra. Re(DES)cobrindo o outro. In. ARRUDA, Ângela (Org.) et. al. Representando Alteridade, $2^{2}$ Ed..Petrópolis, RJ: Vozes, 2002, p. 69-82.

JULIANO, Dolores. El trabajo sexual em La mira. Polêmicas y estereótipos. Cadernos Pagu (25), Campinas-SP, Núcleo de Estudos de Gênero Pagu/Unicamp, jul./dez. 2005, pp.80-88.

KAPPAUN, Alexandre de Oliveira. Tráfico de mulheres, feminismo e relações internacionais: uma abordagem histórica.. In: $3^{\circ}$ ENCONTRO NACIONAL ABRI 2001, 3., 2011, São Paulo. Proceedings online... Assosciação Brasileira de Relações Internacionais Instituto de Relações Internacionais - USP, Available from:

$<$ http://www.proceedings.scielo.br/scielo.php?script=sci_arttext\&pid=MSC0000000 $122011000100004 \&$ Ing=en\&nrm=abn>. Acess on: 24 Nov. 2013.

KEMPADOO, Kamala. Mudando o debate sobre o tráfico de mulheres. Cadernos Pagu (25), Campinas-SP, Núcleo de Estudos de Gênero - Pagu/Unicamp, jul./dez. 2005, pp. 55-78.

KRELL, Andreas Joachim. Direitos Sociais e Controle Judicial no Brasil e na Alemanha: os (des)caminhos de um Direito Constitucional "comparado". Porto Alegre: Sergio Antonio Fabris, 2002.

KYMLICKA, Will. Multicultural Odysseys. Oxford: Oxford University Press, 2007.

LANE, Sílvia T. O que é Psicologia Social. São Paulo: Brasiliense, 1989.

LEAL, Maria Lúcia; LEAL, Maria de Fátima. (Orgs.). Pesquisa sobre tráfico de mulheres, crianças e adolescentes para fins de exploração sexual comercial no Brasil - PESTRAF. Brasília: CECRIA, 2002. 
LÜDKE, Menga; ANDRÉ, Marli. E. D. A. Pesquisa em Educação: abordagem qualitativas. São Paulo: EPU, 1986.

MARZAGÃO, Laerte (Coord.). Tráfico de Pessoas. São Paulo: Quartier Latin, 2001.

MASSA-ARZABE, Patrícia Helena. Dimensão Jurídica das Políticas Públicas. In: BUCCI, Maria Paula Dallari (Org.). Políticas Públicas - reflexões sobre o conceito jurídico. São Paulo: Saraiva, 2006, p. 01-49.

MENANDRO, Paulo Rogério Meira. A Curva Generosa da Compreensão: Temas em metodologia. In SOUZA, Lídio de; FREITSA, Maria de Fátima Quintal; RODRIGUES, Maria Margarida P. (Orgs.) Psicologia: Reflexões (im)pertinentes. São Paulo: Casa do Psicólogo, p. 397-417, 1998.

MINAYO, Maria Cristina S. O Desafio do Conhecimento. Pesquisa Qualitativa em Saúde. São Paulo-Rio de Janeiro: Hucitec-Abrasco, 1999.

(Org.) et. al. Pesquisa Social - Teoria, Método e Criatividade. Petrópolis: Editora Vozes. 2002.

MINISTÉRIO DA JUSTIÇA. Jornadas Transatlânticas: uma Pesquisa exploratória sobre tráfico de seres humanos do Brasil para Itália e Portugal. Brasília: UNODC/ICMPD, 2011.

MINISTÉRIO DA JUSTIÇA, 2012. Disponível em http://portal.mi.gov.br/data/Pages/MJ4A223E07ITEMID56723894A9BB4E57A53F 4E2C57E319CAPTBRNN.htm, acesso em 10/06/2012.

MOSCOVICl, Serge. A representação social da psicanálise. Rio de Janeiro: Zahar, 1978.

MUSTO, Jennifer Lynne. What's in a name? Conflations and contradictions in contemporary U.S. discourses of human trafficking. Los Angeles: Women's Studies International Forum 32 (2009) 281-287. 
NACIONES UNIDAS, Manual de primeros auxilios para los funcionarios de los servicios de aplicación de la ley encargados de la respuesta inicial en los casos de trata de personas, UNODC, s/d. Disponível em: <http://www.acnur.org/ biblioteca/pdf/7965.pdf>. Acesso em 20 out. 2010.

NACIONES UNIDAS, Manual para la lucha contra la trata de personas, New York, 2007.

NAíM, Moisés. llícito: o ataque da pirataria, da lavagem de dinheiro e do tráfico à economia global. Tradução Sérgio Lopes. Rio de Janeiro: Jorge Zahar, 2006.

NOCCHI, Andrea Saint Pastous; VELLOSO, Gabriel Napoleão; FAVA, Marcos Neves (Coord.). Trabalho Escravo Contemporâneo - 0 desafio de superar a negação. São Paulo: LTr, 2011.

OLIVEIRA, Maria Pereira Pires; CAMPOS, Bárbara Pincowsca Cardoso (Coord). Tráfico internacional de pessoas e tráfico de migrantes entre deportados(as) e não admitidos(as)que regressam ao Brasil via o aeroporto internacional de São Paulo (Relatório). Brasileira: Ministério da Justiça, 2007.

NOVAIS, Denise P. V. Tráfico de pessoas para fins de exploração do trabalho: um estudo sobre o tráfico de bolivianos para exploração do trabalho em condição análoga à de escravo na cidade de São Paulo. 201 f. Tese (Doutorado em Direito do Trabalho) - Programa de Pós-Graduação em Direito da Universidade de São Paulo, São Paulo, 2008.

ORGANIZAÇÃO DAS NAÇÕES UNIDAS (ONU). Pacto de Direitos Civis e Políticos, 1969. Disponível em

http://portal.mi.gov.br/sedh/ct/legis intern/pacto dir economicos.htm, acesso em 21/10/2013.

ORGANIZAÇÃO DAS NAÇÕES UNIDAS (ONU). Convenção de Viena, 14-25 de junho de 1993, Organização das Nações Unidas disponível em http://www.oas.org/dil/port/1993\%20Declara\%C3\%A7\%C3\%A30\%20e\%20Progra ma\%20de\%20Ac\%C3\%A7\%C3\%A30\%20adoptado\%20pela\%20Confer\%C3\%AA 
ncia\%20Mundial\%20de\%20Viena\%20sobre\%20Direitos\%20Humanos\%20em\%20 junho\%20de\%201993.pdf, acesso em 21/10/2013.

ORGANIZAÇÃO INTERNACIONAL DO TRABALHO (OIT). Relatório: Não ao Trabalho Forçado. Genebra: 89aㅗ Reunião da OIT, Conferência Internacional do trabalho, 2001. Disponível em http://www.ilo.org/public/portugue/region/ampro/brasilia/info/download/index.htm. Acesso em 20/06/2011.

ORGANIZAÇÃO INTERNACIONAL DO TRABALHO (OIT). Relatório: Aliança Global contar o Trabalho Forçado. Genebra: 93로 Reunião da OIT , Conferência Internacional do trabalho, 2005. Disponível em:

http://www.oitbrasil.org.br/trabalho forcado/oit/relatorio/relatorio global2005.pdf. Acessado em 20/06/2011.

OROZCO, Rosi; HERNÁNDEZ, Evangelina. Del Cielo ao Infierno em um Día. México: Editoral Diamante, 2011.

PAGLIONE, Eduardo A. "Direitos Humanos para humanos direito": um apotegma ou apenas um quiasmo? São Paulo: ADPESP, 2010, disponível em http://adpesp.org.br/artigos exibe.php?id=134, acessado em 08/07/2012.

PASCUAL, Alejandra. Mulheres vítimas de tráfico para fins de exploração sexual: entre o discurso da lei e a realidade de violência contra as mulheres. In LEAL, Maria Lúcia Pinto; LEAL, Maria de Fátima Pinto; LIBÓRIO, Renata Maria Coimbra. Tráfico de Pessoas e Violência Sexual. Brasília: Universidade de Brasilia/Violes, 2007, p. 43-58.

PEREIRA, Cristiana Schettini. Lavar, passar e receber visitas: debates sobre a regulamentação da prostituição e experiências de trabalho sexual em Buenos Aires e no Rio de Janeiro, fim do século XIX. Cadernos Pagu (25), pp. 25-54, 2005.

PEREZ, Marcos Augusto. A participação da sociedade na formulação, decisão e execução das políticas públicas. In: BUCCI, Maria Paula Dallari (Org.). Políticas 
Públicas - reflexões sobre o conceito jurídico. São Paulo: Saraiva, 2006, p. 163-176.

PIOVESAN, Flávia. A Proteção Internacional dos Direitos Econômicos, Sociais e Culturais. In Temas de Direitos Humanos. São Paulo: Max Limonad, 2003.

PISCITELLI, Adriana. Entre as "máfias" e a "ajuda": a construção de conhecimento sobre tráfico de pessoas". In Caderno Pagu (31), pp. 29-63, 2008.

Trânsitos: Brasileiras no mercado internacional do sexo. Rio de Janeiro: Ed UERJ, 2013.

POMBO-DE-BARROS, Carolina Fernandes; ARRUDA, Ângela Maria Silva. Afetos e Representações Sociais: Contribuições de um diálogo transdisciplinar. In Psicologia: Teoria e Prática, Vol. 26, n. 2, Abr-Jun 2010, pp. 351-360.

QUEIROZ, Maria Isaura Pereira de Variações sobre a técnica de gravador no registro de informação viva. São Paulo: T. A. Editor, 1991.

RAMOS, André de Carvalho. O Supremo Tribunal Federal e o Direito Internacional dos Direitos Humanos. In: SARMENTO, Daniel; SARLET, Ingo Wolfgang (Orgs.). Direitos Fundamentais no Supremo Tribunal Federal Balanço e Crítica. Rio de Janeiro: Lumen Juris, 2011, pp. 03-35.

RAMOS, André de Carvalho. Teoria Geral dos Direitos Humanos na Ordem Internacional. São Paulo: Saraiva, 2013.

RELATÓRIO DA REDE SOCIAL DE JUSTIÇA E DIREITOS HUMANO. In São Paulo: Rede Social de Justiça e Direitos Humanos, 2005, p. 115-120.

SALOMÃO FILHO, Calixto et al. Concentração, Estruturas e Desigualdade: As origens coloniais da pobreza e da má distribuição de renda. São Paulo: Idcid, 2006.

SANTOS, Boaventura de Sousa. Por uma Concepção Multicultural dos Direitos Humanos. Revista Crítica de Ciências Sociais, oㅡ 48, jnho 1997. 
SANTOS, Boaventura de Sousa (Org.). Reconhecer para Libertar. Rio de Janeiro: Civilização Brasileira, 2003.

. Um Discurso sobre as Ciências. São Paulo: Cortez, 2004.

. Conhecimento Prudente para uma vida decente - Um Discurso sobre as Ciências Revisitado. São Paulo: Cortez, 2004a.

. Pela mão de Alice. São Paulo: Cortez, 2005.

. Para uma Revolução Democrática da Justiça. São Paulo: Cortez, 2007.

Poderá o Direito ser Emancipatório? Vitória: FDV; Florianópolis:

Fundação Boiteaux, 2007a.

; MARQUES, Maria Manuel Leitão; PEDROSO, João. Tribunais nas

Sociedades Contemporâneas. Cominbra: Centro de Estudos Sociais (CES), no 65, 1995.

; GOMES, Conceição; DUARTE, Madalena. Tráfico sexual de mulheres: Representações sobre ilegalidade e vitimação. Revista Crítica de Ciências Sociais, 87, Dezembro 2009, pp. 69-94.

SANTOS, Gislene Aparecida dos. As políticas multiculturais e o reconhecimento de identidades como novas formas de contrato social e efetivação da justiça. CCJUR em Revista, 2010, ISSN 1679-4206

SÃO PAULO. Decreto ํㅜㄴ.101 de 12 de Março de 2009. Diário Oficial do Estado de São Paulo, São Paulo, 13 de mar. 2009.

SÃO PAULO. Resolução SJDC ํo 308, de 18 de janeiro de 2010. Diário Oficial do Estado de São Paulo, Poder Executivo - seção I, Vol. Úmero 12 São Paulo, 19 de jan. 2010, p. 03.

SÃO PAULO, Decreto oficializará Comitês regionais de combate ao tráfico de Pessoas, São Paulo: Secretaria da Justiça e Defesa da Cidadania, 2012. 
Disponível em http://www.justica.sp.gov.br/novo site/Noticia.asp?Noticia=5337, acesso em 10/06/2012.

SARLET, Ingo Wolfgang. Dimensões da Dignidade: Ensaios de Filosofia do Direito e Direito Constitucional. Porto Alegre: Livraria do Advogado, 2005.

SCOTTISH EXECUTIVE. UK Action Plan on Tackling Human Trafficking. Reino Unido: Home Office, Março 2007. Acesso em 25/11/2013. Disponível em http://www.ungift.org/doc/knowledgehub/resourcecentre/Governments/UK Action Plan to Combat Human Trafficking en.pdf.

SECRETARIA NACIONAL DE JUSTIÇA (SNJ). Relatório Final de Execução do I Plano Nacional de Enfrentamento ao Tráfico de Pessoas. Secretaria Nacional de Justiça, Ministério da Justiça, 1르 Ed. Brasília, 2010.

SEN, Amartya. Desenvolvimento como Liberdade. Tradução Laura Teixeira Motta. São Paulo: Companhia das Letras, 2010.

SENA, Jaqueline Santa Brígida. ÉTica da alteridade e Direitos Humanos: uma discussão necessária à formação jurídica contemporânea. In NALINI, José Renato; CARLINI, Angela: Direitos Humanos e Formação Jurídica. Rio de Janeiro: Forense, 2010.

SENADO FEDERAL. Relatório Parcial da Comissão Parlamentar de Inquérito destinada a investigar o tráfico nacional e internacional de pessoas no Brasil, suas causas, consequências, rotas e responsáveis, no período de 2003 e 2011, compreendido na vigência da Convenção de Palermo. Brasília, Dez. 2011. Acesso em 08/06/2012. Disponível em http://www12.senado.gov.br.

SENADO FEDERAL. Relatório Final da Comissão Parlamentar de Inquérito destinada a investigar o tráfico nacional e internacional de pessoas no Brasil, suas causas, consequências, rotas e responsáveis, no período de 2003 e 2011, compreendido na vigência da Convenção de Palermo. Brasília, Dez. 2012. Acesso em 24/11/2013. Disponível em http://www12.senado.gov.br/noticias/materias/infograficos/2012/12/info-trafico-depessoas. 
SOARES, Maria Victória. Cidadania e Direitos Humanos. Cadernos de Pesquisa (104), jul 1998, p. 39-46.

TAYLOR, Charles. Multiculturalismo. Lisboa: Instituto Piaget, 1994.

TEIXEIRA, Flávia do Bonsucesso. L'Italia dei Divieti:entre o sonho de ser europeia e o babado da prostituição. Cadernos Pagu (31). Campinas, julho-dezembro 2008, p. 275-308.

TERESI, Veronica Maria A. Cooperação Internacional para o Enfrentamento ao Tráfico de Mulheres para fins de Exploração Sexual: $O$ Caso BrasilEspanha. Santos, Universidade Católica de Santos/Programa de Direito, Dissertação de Mestrado, 2007, 200f.

TELES, Maria Amélia de Almeida. As Imigrantes Bolivianas em São Paulo: $O$ silêncio insuportável. In LEAL, Maria Lúcia Pinto; LEAL, Maria de Fátima Pinto; LIBÓRIO, Renata Maria Coimbra. Tráfico de Pessoas e Violência Sexual. Brasília: Universidade de Brasilia/Violes, 2007, p. 35-42.

TELLES, Vera. A Pobreza como condição de vida: família, trabalho e direitos entre as classes trabalhadoras urbanas. São Paulo em Perspectiva 4 (2), 1990, p. 37-45.

TORRES, Hédel de Andrade. Tráfico de Mulheres - Exploração Sexual: Liberdade à Venda. Brasília: Rossini Corrêa, 2012.

TRINDADE, Zeide Araújo. Representação social: "modo de conhecer" no cenário da saúde. In ; CAMINO, Leôncio. (Orgs). Cognição e juízo moral. 1 (6) Rio de Janeiro: ANPEPP, 1996, pp.45-59.

. e ENUMO, Sônia Regina F. Representações sociais de infertilidade feminina entre mulheres casadas e solteiras. Psicologia, Saúde \& Doenças, 2 (2), p. 5-26, 2001.

TRIVIÑOS, Augusto N.S. Introdução à pesquisa em ciências sociais - A pesquisa qualitativa em educação. São Paulo: Atlas, 1987. 
TYLDUM, Guri.; BRUNOVSKIS, Anete. Describing the Unobserved:

Methodological Challenges in Empirical Studies on Human Trafficking.

International Migration 43, pp. 17-34, 2005.

UNITED NATIONS OFFICE ON DRUGS AND CRIME (UNODC). Trafficking in Persons: Global Patterns, 2006. Disponível em:

http://www.unodc.org/pdf/traffickinginpersons_report_2006ver2.pdf, acesso em 15 de agosto de 2006.

UNITED NATIONS OFFICE ON DRUGS AND CRIME (UNODC). Global Report on Trafficking in Persons, 2009. Disponível em:

http://www.unodc.org/documents/Global_Report_on_TIP.pdf, acessado em 08/06/2012.

UNITED NATIONS OFFICE ON DRUGS AND CRIME (UNODC). The Globalization of Crime - A transnational Organized Crime Threat Assessment. Viena: ONUDC, 2010. Disponível em:

http://www.unodc.org/documents/data-and-

analysis/tocta/TOCTA Report 2010 low res.pdf, Acessado em 08/02/2012.

UNITED STATES (US)- Department of State. Trafficking in Persons Report 2008. Disponível em: http://www.state.gov/g/tip/tiprpt/2008, acesso em 08/06/2012.

VASCONCELOS, Karina Nogueira (Coord.). Tráfico de Pessoas - Pesquisa diagnóstico do tráfico de pessoas para fins de exploração sexual e de trabalho escravo em Pernambuco: Asseplanap, Recife, Ago-2009. (ESAMC WACQUANT, Löic. As Prisões da Miséria. Rio de Janeiro: Jorge Zahar, 2001.

WAISELFISZ, Júlio Jacob. Mapa da Violência 2012 - Crianças e Adolescentes do Brasil. Rio de Janeiro: Cebela e Flacso, 2012.

WALDMAN, Tatiana Chang. 0 Acesso à Educação Escolar de Imigrantes em São Paulo: a trajetória de um Direito. São Paulo: Universidade de São Paulo/Faculdade de Direito - Direitos Humanos, Dissertação de Mestrado, 2012. 
WARAT, Luis Alberto. Epistemologia e Ensino do Direito - o sonho acabou. Florianópolis, Fundação Boiteux, 2004.

WEINGARTNER NETO, Jayme; SARLET, Ingo Wolfgsng. Dignidade (da Pessoa) Humana, Direitos Humanos e Fundamentais e Ensino Jurídico: Algumas Aproximações. In NALINI, José Renato; CARLINI, Angélica. Direitos Humanos e Formação Jurídica. Rio de Janeiro: Forense, 2010.

ZENAIDE, Maria de Nazaré Tavares. Introdução, In SILVEIRA, Rosa Maria Godoy (Org.), et. alli. Educação em Direitos Humanos: Fundamentos Teóricos e Metodológicos. João Pessoa. 2007, P. 15-25.

\section{Filmes e Novela:}

ANJOS do Sol. Direção: Rudi Lagemann. Intérpretes: Antônio Calloni; Chico Diaz; Otávio Augusto; Vera Holtz e outros. Roteiro: Rudi Lagemann. Brasil: Downtown Films, 2006 (96 min.), son., color., $35 \mathrm{~mm}$.

BIUTIFUL. Direção: Alejandro Gonzáles Iñárritu. Produção: Fernando Bovaira, Alejandro González Iñárritu, Jon Kilik . Intérpretes: Javier Bardem; Eduard Fernandez e outros. Roteiro: Alejandro Gonzáles Iñárritu. EUA: Focus Features/Mod Producciones, 2010. (147 min.), son., color., 35 mm.

CENTRAL DO BRASIL. Direção: Walter Salles. Produção: Arthur Cohn e Martine de Clermont-Tonnerre. Intérpretes: Fernanda Montenegro, Marilia Pera, Vinícius de Oliveira. Roteiro: João Emanuel Carneiro, Marcos Bernstein, Walter Salles. Brasil: VideoFilm, Riofilm, Mact Productions, 1998 (113 min.), som, cor, 35 mm.

CINDERELAS, lobos e um príncipe encantado. Direção: Joel Zito Araújo. Produção: Joel Zito Araújo; Luis Carlos de Alencar. Intérpretes: Documentário. Roteiro: Joel Zito Araújo e José Carvalho. Brasil: 2009. (106 min.), son., color., 35 $\mathrm{mm}$.

COISAS Belas e Sujas (Título Original: Dirty Pretty Things). Direção:Stephen Frears. Produção: Miramax Films. Intérpretes: Audrey Tautou; Chiwetel Ejiofor; 
Sergi López; Sophie Okonedo e outros. Roteiro: Steven Knight. Reino Unido: Miramax Films; BBC Films; Celador Productions, 2002. (97 min.), son., color., 35 $\mathrm{mm}$.

TRADE - Desaparecidos. Direção: Marco Kreuzpaintner. Produção: Rosilyn Heller; Roland Emmerich. Intérpretes: Kevin Kline; Alicja Bachleda-Curus; Paulina Gaitan e outros. Roteiro: Jose Rivera. EUA: Paris Films, 2007 (119 min.), son., color., $35 \mathrm{~mm}$.

SALVE JORGE. Direção: Marcos Schechtman e Fred Mayrink. Escrita por Gloria Perez. Elenco: Nanda Costa, Rodrigo Lombardi, Giovanna Antonelli, Claudia Raia e outros. Brasil: Rede Globo de Televisão, 2012-2013 (179 capítulos), novela.

TRÁFICO Humano (Título Original: Human Trafficking). Direção: Christian Duguay. Produção: Intérpretes: Donald Sutherland;. Mira Sorvino, Robert Carlyle e outros. Roteiro: n/c. Canadá/EUA: Alpha Films. 2005. (176 min.), son., color., $35 \mathrm{~mm}$. 


\section{9 - ANEXO}

\section{Universidade de São Paulo \\ Programa de Pós-Graduação - Faculdade de Direito \\ TERMO DE CONSENTIMENTO PARA PARTICIPACÃO EM PROJETO DE PESQUISA - Doutorado}

Concordo em participar do projeto de pesquisa abaixo discriminado, nos seguintes termos:

Projeto: Direitos Humanos, Políticas Públicas e Tráfico de Pessoas

Responsável: Fernanda de Magalhães Dias Frinhani

Instituição: Universidade Federal de São Paulo

\section{Justificativa e Objetivo da Pesquisa:}

O presente estudo busca uma interlocução entre os Direitos Humanos e a Psicologia, a partir de uma proposta de análise das representações sociais de tráfico de pessoas por operadores do direito, restringindo-se aos operadores do direito envolvidos com a implantação da Política de Prevenção e Enfrentamento ao Tráfico de Pessoas no Estado de São Paulo.

\section{Descrição dos Procedimentos a que o Participante será submetido:}

Serão realizadas entrevistas semi-estruturadas com questões pertinentes aos objetivos da pesquisa. As entrevistas serão gravadas com o consentimento dos participantes.

\section{Benefícios Esperados:}

Os resultados da pesquisa serão divulgados através da participação em congressos e publicação de artigos em periódicos especializados, contribuindo para a ampliação do corpo de conhecimentos que se tem produzido sobre a atuação dos operadores do Direito na Política de Prevenção e Enfrentamento ao Tráfico de Pessoas. Espera-se que os resultados possam gerar subsídios para a implementação de projetos de intervenção e capacitação de profissionais envolvidos em Políticas de Direitos Humanos.

\section{Identificação do Participante:}

Nome:

Função:

Órgão:

Estando assim de acordo, assinam o presente termo de consentimento em duas vias.

\section{Participante}

São Paulo, de de 20 